УНИВЕРЗИТЕТ У БЕОГРАДУ

ГЕОГРАФСКИ ФАКУЛТЕТ

ВЕСНА М. ЛУКИЋ

КОНВЕРГЕНТНЕ И ДИВЕРГЕНТНЕ

ДНЕВНЕ МИГРАЦИЈЕ

СТАНОВНИШТВА ПАНЧЕВА

-ДОКТОРСКА ДИСЕРТАЦИЈА-

Београд, 2008. 


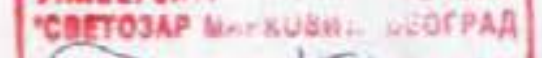

Sil 152062

2. $\operatorname{sen}$ 
Ментор: Проф.др Милена Спасовски, Географски факултет Универзитета у Београду.

Чланови комисије: Проф.др Србољуб Стаменковић, Географски факултет Универзитета у Београду; проф. др Милан Бачевић, ПМФ Приштина, са привременим седиштем у Косовској Митровици

Докторат наука из области демографије 


\section{Конвергентне и дивергентне дневне миграције становништва Панчева}

Апстракт: У овој дисертацији тежиште је на проучавање конвергентних и дивергентних токова становништва у дневном урбаном систему Панчева. Анализа дневних миграција становништва на националном нивоу, која је извршена након дискусије теоретских сазнања из ове области, омогућава поређење развоја и савремених тенденција одвијања дневних миграција у Србији и шире. Фактори који утичу на одлуке везане за процес дневних миграција у Србији и просторну дистанцу путовања испитани су на примеру дневних миграната Панчева (због посебне обраде података Пописа становништва из 2002. године за ову групу дневних миграната). На основу тога су испитане карактеристике породище дневног мигранта и утицај фазе животног циклуса на дневну миграцију.

Специфичност Панчева која се огледа у ширем националном и регионалном значају панчевачке индустрије, као и непосредној близини Београда, била је важна полазна основа приликом проучавања дневних миграција становништва у урбаном систему Панчева. Дефинисано је функционално подручје Панчева и одређен демографски профил дневног мигранта урбаног система Панчева. Додељивањем варијабле "дужина пута" дневном мигранту извршено је тестирање утицаја демографских и социо-економских фактора на просечну дужину путовања дневног мигранта у једном смеру, а што је омогућило потврду различитог деловања демографских и социо-економских фактора на просторну раздаљину дневне миграције за мушкарце и жене. Помоћу софтверског програма SAS коришһен је $t$ mecm за испитивање статистичке значајности разлика у просторној раздаљини дневне миграције према полу. Брачни статус и присуство деце, као најчешһе коришћени индикатори за испитивање хипотезе о одговорности у домаћинству, показали су се значајни и за варијације у просторној раздаљини дневне миграције према полу на примеру дневних миграната Панчева. Такође је анализиран утицај броја запослених у домаһинству и породичне структуре на просторну раздаљину дневне миграције, као и веза између дневне и дефинитивне миграције.

Кључне речи: дневне миграције, Србија, Панчево, просечна дужина путовања, родне неједнакости, типови породица. 


\title{
Convergent and Divergent Commuting Flows of Pančevo Population
}

\begin{abstract}
This dissertation analyzes convergent and divergent commuting flows of population in daily urban system of Pančevo. Analysis of commuting on national level, gained after discussion of theoretical cognitions in this field, enables comparison between development and modern tendencies of commuting in Serbia and other countries. Determinants that affect commuting decisions and mean travel distance of commuters in Serbia were examined on example of Pančevo commuters (due to specially processed data from 2002 Census for this group of commuters). Based on this data, family types of commuters and effect of life cycle on commuting have been analyzed.

In this research we started from national and regional importance of industry in Pančevo and its location near Belgrade. Funcional area of Pančevo has been defined together with demographical profile of commuter of daily urban system of Pancevo. By allocating of the variable "mean travel distance" to commuter, we have tested influence of demographic and socioeconomic determinants on the mean travel distance of commuter in one way. That enabled us to confirm different acting of demographic and socioeconomic factors on mean travel distance for men and women. With SAS program $t$-test has been used to explore statistical significance of differences in everyday spatial distance of commuters by sex. Marital status and presence of children, as often used indicators for examining hypothesis of household responsibility, proved to be important for variations in mean travel distance of commuters on example of daily urban system of Pančevo. Mean travel time differences between dual and single earner households, effects of presence of family structure in household and relations between commuting and migration have also been analyzed.
\end{abstract}

Key words: Commuting, Serbia, Pančevo, Mean Travel Distance, Gender Differences, Family Types. 


\section{САДРЖАЈ}

УВОДНА РАЗМАТРАЊА 1

\section{TEOРЕТСКА САЗНАНА}

О ПРОЦЕСУ ДНЕВНИХ МИГРАЦИЈА СТАНОВНИШТВА .............................. 3

1.1. Значај проучавања дневних миграција становништва...................................... 3

1.2. Оцена предности и недостатака различитих извора података

о дневним мигращијама становништва за потребе научних проучавања.................. 6

1.3. Преглед тенденција у истраживањима дневних миграција.............................. 8

1.4. Теоретски аспекти проучавања дневних миграпија..................................... 11

1.5. Дефиниција дневне миграције, положај дневних миграција у миграционим типологијама и типологија дневних миграната............................................... 17

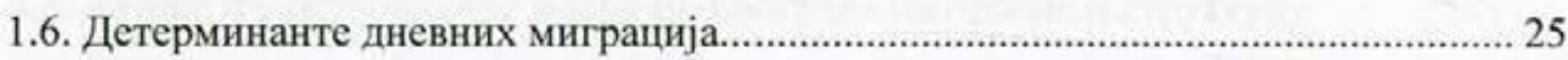

1.7. Временска и просторна димензија дневне миграције.................................... 30

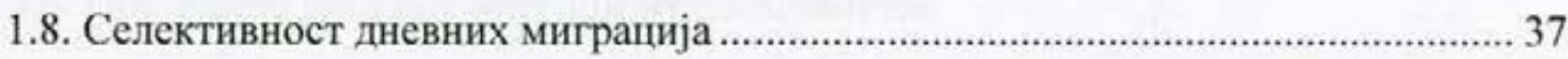

1.9. Природа везе између дневне и дефинитивне миграције................................ 42

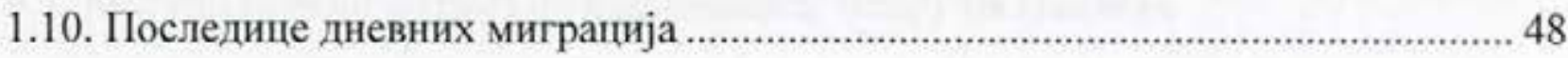

II ДНЕВНЕ МИГРАЦИЈЕ СТАНОВНИІІТВА У СРБИЈИ И СВЕТУ ............... 51

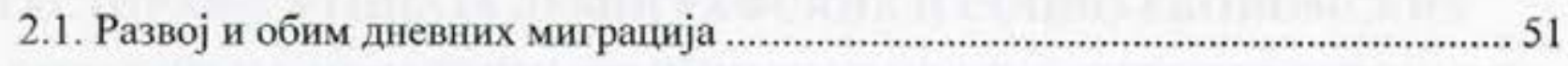

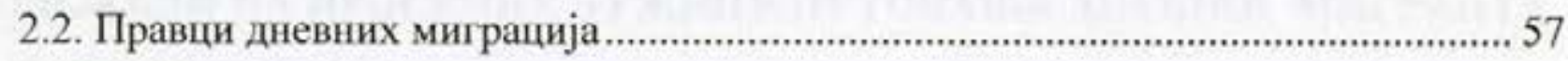

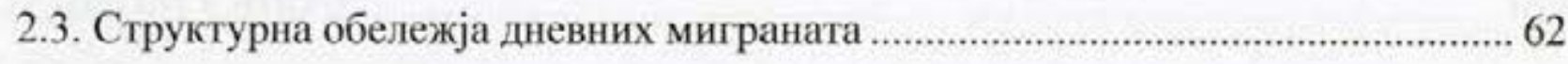

III ДЕТЕРМИНАНТЕ ОБИМА, СТРУКТУРЕ И ПРАВАЦА ТОКОВА

ДНЕВНИХ МИГРАЦИЈА АКТИВНОГ СТАНОВНИШТВА И ШКОЛСКЕ И

СТУДЕНТСКЕ ОМЛАДИНЕ ДНЕВНОГ УРБАНОГ СИСТЕМА ПАНЧЕВА.... 64

3.1. Гео-саобраћајни и друштвено-економски положај Панчева као детерминанте обима и територијалног домета дневних миграција.

3.2. Популациона динамика и промене у просторном размештају становништва као детерминанте обима и територијалног домета дневних миграција

3.3. Природна и миграциона компонента демографског развоја као детерминанте обима и територијалног домета дневних миграција.. 75

3.4. Развој дневних миграшија као детерминанта обима и територијалног домета савремених миграционих токова дневног урбаног система Панчева . 86

3.5. Промене у основним структурама становништва и домаћинстава као детерминанта обима и територијалног домета дневних мигращија. 
3.6. Функционални развој и улога индустрије и стања на тржишту рада као детерминанти обима и територијалног домета дневних миграција

IV КОНВЕРГЕНТНЕ И ДИВЕРГЕНТНЕ ДНЕВНЕ МИГРАЦИЈЕ РАДНИКА, УЧЕНИКА И СТУДЕНАТА ДНЕВНОГ УРБАНОГ СИСТЕМА ПАНЧЕВА ... 127

4.1. Просторна димензија дневног урбаног система и дефинисање функционалног подручја Панчева

4.2. Структурна обележја популащије дневних миграната

4.3 Анализа везе између дневне и дефинитивне миграције

(миграционе карактеристике дневних миграната)

4.4. Типологија насеља Панчева према критеријуму обележја дневне миграције и издвајање зона утицајне сфере Панчева.

4.5. Утицај функционалног подручја Београда на правце и структуру миграционих токова дневног урбаног система Панчева

4.6. Последице дневних миграција становништва

на трансформацију геопростора општине Панчево

4.7. Могући правци развоја функщионалног подручја Панчева

и њему коресподентних дневних урбаних система 165

\section{V ТЕСТИРАњЕ УТИЦАЈА ДЕМОГРАФСКИХ И СОЦИО-ЕКОНОМСКИХ} ВАРИЈАБЛИ НА ПРОСЕЧНУ ДУЖИНУ ПУТОВАЊА ДНЕВНОГ МИГРАНТА У ЈЕДНОМ СМЕРУ

5.1. Просечна просторна дистанца конвергентних и дивергентних миграната дневног урбаног система Панчева 169

5.2. Статистичка анализа и дискусија статистичких резултата 173

VI ЗАКљУЧАК 177

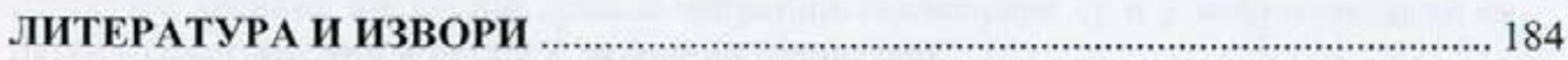

ЛИТЕРАТУРА И ИЗВОРИ НА ЕНГЛЕСКОМ ЈЕЗИКУ ................................ 189

ПРИЛОЗИ 


\section{УВОДНА РАЗМАТРАњА}

Различити облици просторне покретљивости становништва у сфери су интересовања многих научних дисциплина, као узрок и последица демографског, економског, социјалног и културног развоја на локалном, регионалном и светском нивоу. Дневне миграције становништва представљају веома сложен феномен географске раздвојености места рада/школовања и места становања дела активног становништва и школске и студентске омладине. Ово проучавање конвергентних и дивергентних дневних миграција Панчева представљено је као теоретски заснована емпиријска анализа са жељом да резултати истраживања, проширивањем досадашњих сазнања, допринесу дисциплини демографије и теоретском сагледавању дневних миграција, али и евентуално помогну у формирању основе за одговарајућу политику дневних миграција у оквиру популационе политике и политике просторног, и локалног и регионалног развоја уопште.

Основни ұиљ овог истраживања дневних миграција јесте експликација, као главни битни циљ научног сазнања, односно дубље сазнање структуре, веза, узрока, последица, промена и развоја токова дневних миграција ка/са простора општине Панчево. Истраживање има за циљ проучавање промена обима и праваца дневних миграција, законитости просторног размештаја популације дневних миграната, као и истраживање селективности дневних миграната (активног становништва и школске и студентске омладине) према основним демографским и социо-економским обележјима, и на основу овог демографског параметра одређивање функционалног подручја дневног урбаног система Панчева. Нагласак је стављен на дневне миграционе токове активног становништва због већег броја фактора који у случају активног становништва делују на миграциони процес. У питању је идентификација главних фактора од којих зависи обим и структура токова савремених конвергентних и дивергентних дневних миграција активног становништва на посматраном простору.

Ово истраживање има за циљ и проучавање потенцијалних ефеката дневне миграције на развој места сталног становања и исходишта дневне миграције (демографски ефекти посебно у вези са дефинитивним миграцијама, као и економски, социјални и културни ефекти везани за прожимање урбаних и руралних утицаја), али и тестирање различитих хипотеза о факторима утицаја на процес дневне миграције, просторну раздаљину, димензије обухвата и правац дневне миграције. Емпиријски резултати послужили су да се укаже, у којој се мери помоћу постојећих теоријских приступа, метода и техника, а на основу одговарајуће обрађених дисагрегатних података могу изучавати законитости развоја конвергентних и дивергентних дневних миграција становништва, у овом случају на примеру Панчева, као и да се сагледа применљивост добијених резултата. Поред изучавања трендова обима, путања и структуре дневних миграција, дневне миграције посматране су и у међузависности са другим демографским и осталим развојним процесима,

Истраживање које има за предмет и циљ спознају сложеног феномена дневног кретања активног становништва, школске и студентске омладине у комплексним функционалним везама дневних урбаних система, подразумева да се ради о мултидисциплинарном истраживању на релацији популационих система и осталих геопросторних система. Из напред предложеног оквира постављене су следеће радие xunomese:

- Просторна коресподентност Панчева и Београда као већих градских система има ефекте у преплитању њихових нодалних регија, испољених преко демографског

\footnotetext{
' Рална хипотеза јесте претпоставка за коју располажемо извесним разлозима за њено усвајање и за коју смо уверени да һе нам у истраживању бити корисна, играјуһи сазнајну улогу у истраживању (Šešić,1980).
} 
феномена дневних миграција активног становништва које обавља занимање и школске и студентске омладине.

- Достигнут ниво демографског, економског, социјалног и културног развоја Панчева и његов географски положај детерминанте су обима и територијалног домета дневних миграција као посебног облика покретљивости активног становништва и школске и студентске омладине према Панчеву из ширег функционалног подручја Београда, јужног Баната и Подунавља.

- Ранг Београда у функционалној структури урбаних центара Србије и територијална и функционална коресподентност Београда и Панчева резултира снажним дивергентним дневним миграцијама активног становништва и школске и студентске омладине из Панчева према Београду.

- Дневне миграције активног становништва и школске и студентске омладине наведеног урбаног система одликује селективност по бројним демографским, и социо-економским обележјима у поређењу са аутохтоном популацијом Панчева.

- Постоји зависност између социоекономских и демографских карактеристика дневних миграната и структуре и обележја њихових домаћинстава, и обима и праваца дневних миграција.

- Прерастање дневне миграције у дефинитивну миграцију има важан потенцијални демографски ефекат у односу на простор емиграције и простор имиграције, као и ефекте и на друге елементе геопросторних система.

Предмет, циљ истраживања и радне-полазне хипотезе намећу превасходно потребу коришћења системског приступа као опште методологије у истраживању сложених популационих феномена, какав представљају и дневне миграције. Сложен и широк методолошки оквир системског приступа допуњен је и другим основним научним методама (метод анализе и синтезе, компаративни метод итд.), као и посебним научним методама релевантним у популационим истраживањима (статистичке методе, демографске методе, картографске методе итд.). Наглашена бројност функционално повезаних испитиваних обележја и бројност територијалних јединица (појединачних насеља) која улазе у оквир овог истраживања наметнули су потребу прецизног проблемски и територијално дефинисаног програма статистичке обраде података о дневним мигрантима и моделовања добијених резултата у табеларном, графичком и картографском облику.

Ка извор података за проучавање конвергентних и дивергентних дневних миграција Панчева коришһени су резултати посебне обраде Пописа становништва из 2002. године, како би се добио што већи спектар информација о карактеристикама дневних миграната и њихових породица. Укрштене су табеле места становања и места рада заједно са одређеним демографским и социо-економским обележјима дневних миграната (старост, пол, брачно стање, школска спрема, делатност - за раднике; пол и тип школе за ученике), што је омогућило сагледавање путања и утврђивање доминантних праваца дневних миграција различитих контингената становништва. Унакрсно табелирање података о дневним миграцијама становништва према/из Панчева омогућило је проучавање функционалног деловања појединачних насеља и дефинисање функционалног подручја Панчева и њему коресподентних дневних урбаних система. Извршено је и унакрсно табелирање података о дефинитивној и дневној миграцији како би се анализирала веза између ова два типа просторне покретљивости становништва, с обзиром да дневне миграције често резултирају дефинитивним пресељењем. Посебном обрадом података Пописа становништва изведене су породице дневних миграната према насељима становања и рада, са циљем дефинисања различитих група породица 
према учешћу чланова у дневној миграцији и другим карактеристикама ради тестирања тзв. хипотезе одговорности у домаћинству ${ }^{2}$.

Такође су посебно обрађени и подаци о конверегентним и дивергентним дневним мигрантима Панчева према стамбеном статусу и поседовању пољопривредног газдинства, са циљем провере теоретских сазнања о утицају ових варијабли на дневне мигранате (вероватноћу учешћа у дневној миграцији и просторну и временску раздаљину дневне миграције). Посебно табелирање и обрада дисагрегатних статистичких података омогућили су примену математичко-статистичких метода и софтверског програма SAS за потребе утврђивања релевантних фактора утицаја на конвергентне и дивергентне дневне миграције Панчева и процену квантитативног значаја разних фактора. Обим, правци и обележја дневних миграната картографском обрадом представљени су у виду тематских карата.

Приликом проучавања дневних миграција Панчева уважена су досадашња теоретска сазнања о дневном миграционом процесу уопште, његовим узрочним факторима и последицама.

\section{TEОРЕТСКА САЗНАЊА О ПРОЩЕСУ ДНЕВНИХ МИГРАЦИЈА СТАНОВНИІІТА}

\section{1. Значај проучавања дневних миграција становништва}

О значају миграција у одређеном социо - економском систему Голдштајн каже: релевантно је знати у односу на целокупни систем, не само ко се креће и одакле, него и какав облик то кретање поприма, зашто је такав облик одабран и какав утицај имају промене разних облика покретљивости на место порекла или одредишта, као и на оне који учествују у просторној покретљивости (Goldstein S., 1981 према Roca O., 1986). Дневне миграције становништва представљају како популационе тако и друштвено економске и културне везе између подручја становања и рада дневних миграната, са бројним узроцима али и последицама на оба простора. Процес дневних миграција нарочито економски активног становништва, с обзиром да је чврсто повезан са демографским развојем, развојем привреде, саобраћаја, насеља, као и развојем тржишта рада и тржишта некретнина има широке импликације у свим сферама живота и рада становништва насеља становања и насеља рада. Дневне миграције су такође један од начина обезбеђивања радне снаге у актуелним условима негативног природног прираштаја у већини насеља Србије. Стога сагласно њиховом значају постоји потреба за праћењем промена елемената и фактора дневних миграција у различитим условима и на раличитим просторима ради боље спознаје дневног миграционог процеса. Проучавање дневних миграција, као посебног облика просторне покретљивости становништва, праваца њихове усмерености, детерминанти, последица, популационог обима и структуре дневних миграната према различитим обележјима има не само научни већ и апликативан значај.

\footnotetext{
${ }^{2}$ Под хипотезом одговорности у домаћинству сматра се да због тога што обављају већи део обавеза у домаћинству, а што им отежава да ускладе пословне и породичне обавезе, жене свакодневно путују до посла на краһим релацијама од мушкараца. Као показатељ одговорности у домаһинству најчешһе се користи брачно стање жена, присуство деце, године старости деше и број одраслих чланова домаһинства. Акценат је на домаһинствима са два радника (тзв. two earner households) 36оr претпоставке да је за два радника у домаһинству теже да обоје нађ)у запослење у локалној средини. Детаљније о појму хипотезе одговорности у домаһинству видети у радовима Johnston-Anumonwo I. (1992) "The Influence of Household Type on Gender Differences in Work Trip Distance" и Turner T., Niemeier D. (1997) "Travel to work and household responsibility: new evidence".
} 
Истраживање промена праваца, обима, и квалитативних карактеристика популације дневних миграната доприноси формулисању одговарајуће развојне популационе и економске политике (а тиме и политике тржишта рада) различитих функционалних подручја које дневне миграције повезују. Резултати проучавања дневних миграција становништва, поред тога што доприносе теоретским сазнањима из области просторне покретљивости становништва, практично су применљиви у многим сферама живота. Утврђивање броја дневних миграната нпр. (корисника услуга и инфраструктуре насеља рада, односно тзв. сервисне популације), у односу на становништво које станује у одређеном месту, значајно је са становишта саобраһаја, инфраструктуре и заштите животне средине.

Дневне миграције имају значајне импликације на пораст обима саобраћаја и загађења у градовима. С обзиром на пораст броја становника и радника у градовима, све су чешћа истраживања на тему одрживог развоја ${ }^{3}$ градова. Развој одрживе саобраһајне политике једна је од највеһих тешкоһа са којом се локалне градске власти најчешће суочавају. Чест индикатор урбане одрживости јесте број пређених километара на једног становника, као показатељ колико становници "произведу" саобраһаја и загађења. Праћење путања дневних миграција омогућава процену места највећег саобраћајног загушења, у време долазака и одлазака радника са посла, и одређивање приоритета у планирању развоја саобраһајне мреже и услуга. О значају времена свакодневно утрошеног на путовање до посла и назад говори чињеница да је управо овај показатељ одабран приликом испитивања најстреснијих/најбољих места за живот као једна од четири најзначајније варијабле, од укупно девет, за избор најстреснијег града у САД. Остале варијабле су стопа незапослености, стопа криминала и стопа власничког криминала (www. bestplaces.net). Проучавање дневних миграција са аспекта саобраћаја важно је не само ради подузимања мера за смањење саобраһајне гужве, буке и загађења на одређеним деоницама, већ и да би се планским мерама развоја саобраћајне мреже и услуга омогућило становништву у што већој мери да се запосли без промене места боравка, односно да замени евентуалну дефинитивну миграцију дневном миграцијом. Тако се избегавају негативни ефекти дефинитивне миграције како на мигранта, тако и на насеља полазишта и одредишта. Овом процесу доприноси и све већа флексибилност тржишта рада.

Помоћу дневних миграција становништва усклађује се понуда и потражња радне снаге између два подручја, како у квантитативном, тако и у квалитативном погледу. Дневне миграције радника су битан индикатор утицаја центара запошљавања, и њихове путање могу послужити као основа за одређивање граница тржишта радне снаге и резерви радне снаге (имајући у виду дневне мигранте). Зато приликом одређивања локације нових индустријских постројења и других центара рада треба узети у обзир колико далеко су радници вољни да свакодневно путују до посла. Израз тржиште рада први пут је дефинисан 1945. године од стране Ратне Комисије у Вашингтону као географско подручје које окружује централни град (или градове уколико су удаљени само неколико миља) у коме су концентрисане потребе за радном снагом и у коме радници могу мењати радно место без промене места пребивалишта. У том смислу путање дневних миграната запослених радника могу се сматрати као приближна мера географског обима било ког тржишта рада (Thompson J.H., 1956).

Миграције се најчешће сматрају као демографски и економски негативан процес, међутим бројна су истраживања која показују да дневне миграције, као посебан

\footnotetext{
${ }^{3}$ Одрживи развој, као развојна парадигма, представља свеобухватни приступ који се тиче економског, социјалног и развоја животне средине без штетних последица. Детаљније о појму одрживог развоја видети у раду Д. Миљановић (2001) "Теоријско поимање и одређење одрживог развоја као нове парадигме развоја".
} 
облик просторне покретљивости становништва, имају и позитивне ефекте како на насеље становања тако и на насеље рада. У том смислу посебно је значајан однос између дневне и дефинитивне миграције. Претпоставка је да се дневни мигрант неће одлучити на пресељење у место рада све дотле док су трошкови његовог свакодневног путовања до посла мањи од трошкова пресељења, или док удаљеност између места становања и места рада не достигне одређену критичну вредност. Прилив прихода које дневни мигранти остварују радом у другом, најчешһе економски просперитетнијем, насељу има позитивне ефекте на развој места становања радника. На тај начин се помоћу дневних миграција радника у одређеној мери одржава равнотежа између економских развијенијих и неразвијених подручја. Слабије развијена подручја преко свакодневног путовања дела активног становништва у друго насеље успевају да задрже своје популационе ресурсе и прилив прихода остварених у другом насељу, на краћи или дужи временски рок. Чињеница да служе као место пребивалишта за дневне мигранте омогућава малим градовима да имају прилив дохотка готово као што би им донела мала фабрика или радња (Parr J.B., 1987). На примеру Летоније и Литваније нпр. доказано је да дневна миграција смањује разлике између зарада становништва села и града и да су њени ефекти позитивни за земљу чак и када се укључе трошкови дневне миграције (Hazans M.,2004).

Већина аутора који се баве проучавањем дневних миграција у Источној Европи дошли су до закључка да су дневне миграције важно краткорочно и средњорочно средство политике урбаног развоја које непосредно утиче на ограничење раста веһих градова и тиме на смањење трошкова градње комуналне и социјалне инфраструктуре у градовима. У неким земљама дневне миграције функционишу као директна или индиректна мера политике просторног развоја као замена или допуна за дефинитивну миграцију (Roca O., 1986). Значај дневних миграција за политику просторног развоја истичу и домаћи аутори. "Дневне миграције су значајан елеменат урбанистичког и руралног планирања појединих насеља. Као показатељ јачине и граница функционалне привлачности насеља дневне миграције становништва омогућавају утврђивање хијерархијско-функционалног ранга насеља, израду типологије насеља, издвајање дневних урбаних система, као и проучавање деловања утицаја централног насеља на промене у структури становништва и физиономско-морфолошкој структури насеља становања" (Stamenković S.,1987).

Бројна истраживања показују да дневне миграције имају кључну улогу у стратегијама прилагођавања појединаца и домаһинстава промењеним условима савременог живота. Зато све више јача свест о потреби већег "стратегијског приступа управљању локацијом и мобилношћу људских ресурса, за добро како појединаца и њихових домаћинстава тако и предузећа и друштва у целини" (Pooley,Turnbull,2005). С тим у вези сазнања о обиму и правцима радне снаге и структури дневних миграната послужиће развојним политикама, да подрже овај облик просторне покретљивости становништва као меру миграционе и популационе политике, а са циљем деловања на смањивање даље концентрације становништва у урбаним центрима и успоравање исељавања становништва из насеља са слабим економским потенцијалима, односно одржавање њихове демографске стабилности. Подстицање развоја дневних миграција допринело би хомогенијем демографском развоју општина и њихових припадајућих региона. Познавање детерминанти дневних миграција може послужити за евентуално подстицање делимичног преусмеравања дневних токова радне снаге одређеним мерама.

Проучавање дневних миграција становништва Панчева нарочито је значајно због непосредне близине Београда и његовог ранга у функционалној структури урбаних центара Србије, те чињенице да је Панчево значајан национални индустријски центар, а индустрија сектор са највећим обимом дневне миграције у нашој земљи. 


\section{2. Оцена предности и недостатака различитих извора података о дневним миграцијама становништва за потребе научних проучавања}

Систематско научно истраживање дневних миграција становништва и формирање довољног фонда чињеница потребно је да би се засновала одређена теорија која би послужила као објективна основа за стратегију друштвено-економског развитка, посебно за теорију просторног, урбаног и руралног планирања (Живковић М., 1980). Детаљнија обрада података о дневним миграцијама становништва омогућава тестирање неких основних теоретских хипотеза, што доприноси теоретским сазнањима о феномену дневне миграције као посебном облику покретљивости становништва, али исто тако има и практичан значај за локалне и регионалне развојне политике.

Истраживање дневних миграција становништва у Србији најчешће се заснива на проучавању на основу једног од два извора података о дневним миграцијама. То су Попис становништва и анкета. Као извори података о дневним миграцијама у свету користе се још саобраћајне студије и подаци управе предузећа у којима дневни мигранти раде. У зависности од тога који се извор података користи за проучавање дневних миграција различити су и методолошки проблеми и могућности за истраживање. Сваки од извора података има одређене предности и ограничења за изучавање процеса дневних миграција. У том смислу приступили смо дискусији методолошких проблема и могућности за истраживање дневних миграција становништва у нашој земљи на основу различитих извора података (расположива статистичка грађа, анкетна испитивања).

Попис становништва, као извор података за проучавање дневних миграција становништва, је најсвеобухватнији јер садржи податке о дневним миграцијама на простору целе државе. И поред предности пописних података у погледу великог обухвата и чињенице да подаци нису дати само за одређену локацију, као што је то случај код анкетних истраживања, објављени резултати пописа становништва званичних институција ограничени су за научна истраживања. Резултати су најчешће у форми која није адекватна практичним потребама одређених истраживања. Објављивање резултата Пописа на нивоу одређених административно-територијалних јединица не омогуһава потпуну искористивост потенцијала пописа становништва, као извора података за проучавање дневних миграција. Збирни подаци о дневним мигрантима омогућавају оцену обима и праваца кретања токова радне снаге и ученика/студената дате административно-територијалне јединице. пружајујући податке само о дивергентним дневним миграцијама ученика/студената и радника на нивоу општина. На тај начин је немогуће доћи до сазнања о укупном функционалном дејству одређеног простора. Овако табелирани подаци о дневним миграцијама пружају довољно информација само са аспекта локалног планирања у местима становања дневних миграната.

Још једно од практичних ограничења пописних података за проучавање дневних миграција становништва у нашој земљи јесте чињеница да се веома важно питање за проучавање дневних миграција - питање раздаљине коју дневни мигрант свакодневно прелази до школе/посла, може само непосредно извести. Примера ради дневни мигрант може свакодневно да прелази административно-територијалну границу своје општине било да станује у насељу које је у њеној непосредној близини или је веома удаљено. У оба случаја припадаће истој категорији дневних миграната у објављеним резултатима Пописа становништва. Питање просторне разадљине дневне миграције или још чешһе времена проведеног у путу у једном смеру, као и врсте превозног средства које дневни мигрант користи (с обзиром да врста превозног средства битно утиче на време 
проведено у путу, али и одвијање саобраћаја) већ је уведено у пописни лист великог броја земаға света. У САД је питање о месту рада и врсти превозног средства до посла први пуг укључено још у попису становништва из 1960. године (Schnore L., 1960). У оквиру пописа становништва у Јужној Кореји 1995. године спроведено је истраживање на узорку од $2 \%$, где су носиоци домаһинстава испуњавали детаљан упитник који је укључивао питања везана за путовање до посла за сваког запосленог члана домаһинства. Поред питања везаних за социоекономска обележја, постављена су и питања о времену потребном за путовање до посла и избору врсте превозног средства (Lee B.S., J. Mc Donald,2003). Подаци о врсти превозног средства и броју дневних миграната који се крећу свакодневно на одређеној релацији имају и свој практичан значај за планирање саобраһаја, док је време проведено у путу до школе/посла важна детерминанта за дефинисање категорије дневног мигранта.

Попис становништва пружа податке о дневним миграцијама само у једној временској тачци (у време пописа). Непрекидно праһење дневних миграција по истом принципу, у смислу упоредивости података из више пописа становништва, веома је важно за истраживаче с обзиром да би омогућило компаративну анализу главних токова дневних миграција, који би допринели новим теоретским сазнањима у овој области. Одсуство дужег низа упоредивих података о дневним миграцијама онемогућава одређивање до ког обима је радна снага променила своје путање дневних миграција, односно праћење трендова дневних миграција. Са методолошког становишта, поред промена у обиму важна је и могућност праћења промена у обележјима дневних миграната током времена. Објављени пописни подаци пружају могућност праһења промена у токовима дневних миграција само према полној структури. Нема упоредивих података о карактеристикама радне снаге (образовни ниво, старост) која свакодневно путује између два различита функционална подручја. У односу на претходне пописне године у објављеним резултатима Пописа становништва из 2002. године дивергентни дневни мигранти су додатно табелирани и према делатности у којој раде, што би у наредном периоду могло пружити могућност за анализу промене дивергентних токова дневних миграција према овом обележју. Подаци су дати према секторима из класификације делатности на највишем нивоу агрегације.

Званични пописни подаци имају ограничења и по питању анализе везе између дефинитивне и дневне миграције. Када би у Попису становништва поред питања где сте становали одређене године стајало нпр. питање где сте те године радили могла би се истраживати и спознати природа везе између дневне и дефинитивне миграције.

Често се истиче потреба истраживача за свеобухватнијим и разноврснијим табелирањем резултата Пописа становништва који се објављују. Стандардни програм обраде пописне грађе заснива се више на потребама широког обима крајњих корисника статистичких података, него на специфичним теоријским потребама одређених научних дисциплина, што резултира табелирањем чији подаци дају првенствено глобални приказ стања и релација међу посматраним појавама. 3бог недовољне искоришћеност емпиријског потенцијала пописних података за научне анализе, потребно је даље рашчлањивање општих статистичких почетних података у складу са релевантним просторним, временским и садржинским карактеристикама (Stanković V., Žižić M., Kapuran S., 2000). Да би се потпуније искористио потенцијал Пописа становништва, као извора података за истраживање дневних миграција, могуће је користити информације добијене на основу посебне (нестандардне) компјутерске обраде података пописа 4 .

\footnotetext{
4 О могуһностима које пружа емпиријски материјал пописа становништва и допунско табелирање података, за проучавање прочеса дневне миграције опширније видети у раду В. Станковић "Значај емпиријског потенцијала демографске статистике за мултидисциплинарно проучавање просторнодемографских појава".
} 
Тежиште посебне обраде података пописа је на појединцима, а не на одређеним контингентима, што уз већи број обележја дневних миграната пружа шире могућности за разумевање детерминанти дневних миграција у односу на програм стандардне обраде. Овако дефинисана посебна обрада података Пописа тешко је доступна истраживачима, с обзиром да је веома скупа, јер захтева наменско и додатно ангажовање радника званичних институција. Из тог разлога се истраживачи у великом обиму ослањају на званичне резултате статистике, често ограничавајући своје истраживање.

Анкетна истраживања на основу статистичких узорака, као други често коришћен извор података о дневним миграцијама становништва, обављају се да би се дошло до информација о процесу дневних миграција које нису доступне у пописним подацима. С обзиром да постојећи статистички подаци не омогућавају комплексно сагледавање дневних миграција изражена је потреба за детаљним теренским истраживањима (Stamenković S., 1996). Теренска истраживања дневних миграција становништва путем анкете, премда су ограничена на једну локацију, имају више потенцијала од званичних података статистике за сагледавање радијуса кретања дневног миграната - појединца, просечног броја чланова домаћинства, функционалних контингената токова, мотивације дневне миграције, могућности за трансформацију дневне у дефинитивну миграцију и ефеката дневне миграције на насеља становања и рада дневних миграната.

\section{3. Преглед тенденција у истраживањима дневних миграција}

Прва истраживања неподударности места рада и места становања извршена су у Немачкој крајем 19. века. Тамо је 1900. године проведен први државни попис становништва који је узимао у обзир број лица која раде ван места становања. За тим примером следиле су Швајцарска (1910.г.), Енглеска (1921.r.), Холандија (1947.г.), Савезна Република Немачка (1950.г.) и Чехословачка 1961. године (Runge J., 1991), У Србији, сагледавање токова дневне миграције по први пут омогућавају подаци Пописа становништва из 1961. године. Савезни завод за статистику спровео је 1957. године анкету о дневним мигрантима у 75 насеља Југославије, док се у попису 1961. године први пут јавља питање о месту рада.

Научно проучавање дневних миграција, као посебног облика просторне покретљивости становништва, започиње интензивније од 50-их година 20. века. Најзаступљеније теме у проучавању дневних миграција су разумевање фактора који условљавају различите правце дневних миграција - правце дневних миграција различитих група становништва, затим проучавање одрживости градова, начина коришћења земљишта и урбане структуре (испитивање везе између времена путовања дневног мигранта и величине града и урбане структуре). Тежиште већине истраживања је на идентификацији демографских, социоекономских и просторних фактора одговорних за варијације просторне и временске димензије свакодневног путовања радника на посао.

Првобитне анализе дневних миграција заснивале су се на одређивању општих карактеристика ове појаве на конкретном простору, обима и праваца дневних миграција између места становања и места рада, и оцене њиховог значаја за тржиште рада. Нови правци у овој области истраживања, која се баве дневним митрацијама у односу на друге облике кретања, а нарочито дефинитивне миграције, јављају се од друге половине 60-их година 20. века. Нека од истраживања која се баве овом тематиком спровели су: Р. Лонсдал (1966. г.), истраживање путања индустријских радника у две фабрике у Северној Каролини у САД; Л. Јапа и др. (1971.г.), анализа међузависности између 
дневних миграција, миграција и промене места рада; А. Варнс (1975.r.), еволуција путања дневних миграција на примеру Ливерпула и Манчестера; знатно касније А. Грин и др. (1999 г.) - истраживање зашто и у ком обиму домаћинства могу одлучити да замене дефинитивну миграцију за дневну на примеру Велике Британије.

Прва тестирања хипотезе о варијабилности времена и трошкова дневне миграције у зависности од социоекономских карактеристика становништва налазимо у радовима Л. Рајдера и Ј. Томпсона 1956, године. Неки од аутора који су се такође бавили испитивањима могућих детерминанти које делују на време и просторну дистанцу дневне миграције су: J. Маден (1981г.) - зашто жене раде ближе кући, М.Вајт (1986 г.) - разлике у путањама дневних миграната у градовима према полу, Б. Ли и Ј. Мекдоналд (2003 г.) - испитивање детерминанти које утичу време и дистанцу дневне миграције на примеру Сеула.

Каин (1968) објашњава како раздвојеност места становања и места рада доводи до ефеката на могућности за запослење одређених расних и етничких група. Уводи појам хипотезе просторног неподударања (spatial mismach hypotesis), према којој је у САД незапосленост међу афроамериканцима у центру града повеһана због децентрализације послова. По овој хипотези раскорак између локација становања у центру града и пораста броја послова у предграђу резултира слабијим могућностима за запошљавање становништва центра, при чему се најчешће ради о становништву са нижим примањима и припадницима мањинских расних и етничких група (Каin J., 1968).

Хамилтон (1982 г.) уводи појам “бескорисних" (wastefull) дневних миграција тврдећи да емпиријски докази указују супротно претпоставци да су предвиђене путање дневних миграција оне које своде на минимум дистанцу путовања радника. Ова разлика може се приписати хетерогености радника и места становања. Темом "бескорисних" (wastefull) дневних миграција бавили су се и Вајт 1988 г. и Смол и Сонг 1992 године. Појављују се и радови на тему проширених (extended) дневних миграција, односно дневних миграција које прелазе границе округа из неметрополитанских у метрополитанска подручја у САД (Таaffe и др., 1980). Концепт "прекомерних" дневних миграција (excess commuting) такође је један од приступа проучавању просторне раздвојености места рада и места становања. Концепт "прекомерних" дневних миграција је начин мерења ефикасности урбаног саобраһаја, где се забележени ниво дневних миграција у граду (на основу избора маршуте путовања појединаца) пореди са процењеним теоретским минимумом дневне миграције (Scott и др.,1997 према Horner M.W.,2004). Теоретски минимум дневне миграције дефинише се као путања дневних миграција где сви дневни мигранти бирају место рада тако да би минимизирали трошкове дневне миграције (White M.,1988). Минимум теоретских дневних миграција коришћен као мера прекомерних дневних митрација индикатор је равнотеже послова и стамбеног простора на датом подручју. Што је мања магнитуда процењеног теоретског минимума дневних миграција више има приближних послова у односу на стамбени простор и већа је ефикасност система. Разлике у мобилности, и социоекономским ограничењима објашњавају зашто обим прекомерних дневних миграција варира од места до места. Ниже вредности су индикатор ефикаснијег система. Географском димензијом урбане дневне миграције бавио се и Шен $(2000$ г.) указујући на проблематичне импликације "прекомерних-сувишних" дневних миграција (Shen Q,2000).

Са убрзаним развојем градова, све више се проучава веза између дневних миграција и мреже насеља и урбане структуре. У Пољској су крајем 80-их и почетком 90-их година прошлог века вршена проучавања дневних миграција и фактора који су утицали на њихово формирање, унутар урбанистичких комплекса више насеља, са 
циљем да се укаже на сличности и разлике при формирању миграција у полицентричним и моноцентричним системима (Runge J., 1991). Ђулијано и Смол (1993 г.) проучавају да ли су путање дневних миграција везане за урбану структуру, као и Вандермисен и др. (2003 г.) - анализа промена урбане форме и времена дневне миграције. Швенон, Дилман и Дијст (2004 г.) испитивали су утицај полицентричне структуре града на путање дневних миграната у Холандији, и утврдили да је појединачна варијабилност у понашању дневних миграната већа од ефекта градске структуре (Schwanen T., F.M.Dieleman, M. Dijst,2004).

Проучавање дневних миграција као индикатора одрживог развоја градова све више добија на значају у земљама Западне Европе и Северне Америке. Растућа потреба за сазнањем где се људи крећу везана је за бројне негативне аспекте урбаног развоја (Horner M.W.,2004). Влада велико интересовање истраживача за проблем одржсивог разєоја градова с обзиром да пројекције показују да ће до 2030. године 5 од 8 милијарди људи на земљи живети у градовима, те да he се светска урбана популација утростручити до 2050. године (Population Reports,2002). Делимично због ових негативних утицаја дошло је и до промена везаних за место становања, и запаженог тренда пресељавања становништва из градова у сеоска и приградска насеља у појединим земљама.

У последњој деценији 20. века предмет проучавања аутора који се баве дневним миграцијама је поред разумевања варијација у времену и дистанци дневних миграција између насеља различитих форми, и даље утицај демографских и социоекономских обележја на обим и правце дневних миграција. Приликом испитивања утицаја одређених детерминанти на понашање дневних миграната користе се различите економетријске методе. Све је учесталија анализа разлика у путањама дневних миграција према полу. Једно од првих проучавања у светској литератури на тему разлика у путањама дневних миграција према полу су проучавања Ериксена (Ericksen J., 1977), и J. Мадена (Madden J.F.,1981). Следе истраживања бројних других аутора на ову тему међу којима су: И. Анумново (1992 г.), М. Сермонс и Ф. Копелман (2001 г.), Р. Камстра, (1996г.), Ф. Кристалди (2005 г.). Последњих година добија на значају и проучавање психолошких аспеката дневних миграција. Предмет истраживања чине разлози за дневну миграцију, али и социопсихолошке последице дневних миграција како на појединца, тако и на породице и домаћинства дневних миграната (Bunker B. et al.,1992).

Детаљан преглед досадашњих проучавања дневних миграција у географској литератури Србије извршио је С. Стаменковић (1996). Изучавања дневних миграција по својој обухватности аутор дели у две групе: интегрисана и самостална. Интегрисана проучавања баве се проблемом дневних миграција у склопу других главних географских тема, док самостална проучавања обухватају њихово тумачење као фокусног научног проблема. Прва интегрисана проучавања дневне миграције у географији јављају се у књигама едиције Насеља српских земаља, касније Насеља $и$ порекло становниитва у издању Српске академије наука и уметности. Током педесетих и шездесетих година 20. века проучавања дневних миграција вршена су у оквиру тумачења гравитационих сфера градова и центара Великог, Јужног и Западног Поморавља. Прва детаљнија географска проучавања дневних миграција као фокусног научног проблема јављају се почетком шездесетих година 20. века. Реч је о проучавањима дневних миграција у великим градовима Нишу, Новом Саду и Крагујевцу (Stamenković S.,1996). Од новијих проучавања дневних миграција становништва треба истаћи проучавања дневних миграција на простору Инђије и Старе Пазове аутора Петровић Г. (2001) и Матијевић Д. (2007). 


\section{4. Теоретски аспекти проучавања дневних миграција}

У наредном поглављу дат је осврт на развој теоретско-методолошких приступа просторној покретљивости становништва. С обзиром на обимну литературу у овој области разматрани приступи служе схватању ауторовог виђења феномена дневних миграција, а што је утицало на ниво анализе и одабир обележја за идентификацију детерминанти дневних миграција приликом проучавања конвергентних и дивергентних дневних миграција Панчева.

Теоретски приступи разматрању миграционог процеса су бројни и разноврсни као последица дуготрајног истраживања ове проблематике. Различите миграционе теорије заједно доприносе објашњењу процеса дневне миграције као посебног облика просторне покретљивости становништва. Постојеће теоријске основе служе за утврђивање елемената и фактора дневних миграција и омогућавају извођење хипотеза за анализе. Као предмет проучавања веһег броја научних дисциплина постоје различити аспекти истраживања дневних миграција, који се међусобно разликују и у зависности од нивоа анализе. Микро-аналитички или индивидуалистички приступ проучавању просторне покретљивости становништва усредсређују се на мигранте као појединце. Миграција се тумачи као одлука појединца до које долази услед објективних, најчешће економских, разлога. Поред економских модела миграција, микроаналитички приступ заступљен је и у бихевиористичким моделима, са тежиштем на субјективним разлозима при одлуци о мигрирању. Насупрот микроаналитичком приступу, макро-аналитички приступ разматра миграционе токове у целини, сматрајући их за резултат друштвеноекономских услова и утицаја средине (места полазишта и одредишта миграције) на које појединац не може да утиче. Оба нивоа анализе имају своје предности и недостатке. Недостатак микроаналитичког приступа је у томе што не води рачуна о макроузроцима који утичу на процес миграције у одређеном простору и времену, искључујући улогу друштва у миграционом процесу, док макроаналитички приступ просторној покретљивости становништва занемарује улогу појединца у миграционом процесу. Недостаци постојећих, супротстављених, нивоа анализе миграција и све већа разноврсност облика просторне покретљивости становништва створили су потребу за новим методолошким приступом проучавању миграционих кретања. Тако је дошло до пораста броја истраживања на нивоу домаһинства. Истраживање миграција на нивоу домаћинства, као јединице анализе, адекватније је од напред наведених приступа, јер нуди мезо приступ који омогућава сагледавање и индивидуалних (обележја, аспирације, мотиви), и друштвено-економских (незапосленост, сиромаштво) детерминанти у миграционом процесу. Промене у жсивотном чиклусу ${ }^{5}$ и жсивотном стилу ${ }^{6}$ такође су међу факторима утицаја на миграциони процес, те је посматрање различитих структура домаһинстава миграната (показатеље фазе животног циклуса поред година старости представљају још брачни статус и родитељство) веома значајно за откривање детерминанти миграције. Фаза животног циклуса открива $10 \%$ варијација у расподели времена проведеног код куһе, на послу и у другим активностима (Levinson D.,1999).

До седамдесетих година прошлог века неокласични економски приступ преовладавао је у проучавањима миграција. Овај приступ подразумева да мигранти разматрају различите економске могућности која насеља пружају руководећи се сопственим економским интересима, који су пресудни за миграцију (рационалан

\footnotetext{
${ }^{5}$ Термин животн циклус односи се на промене животних потреба појединца током времена.

${ }^{6}$ Термин жсивотии стил односи се на вредновање одређених аспеката живота од стране појединца. Овај израз у литературу је први увео Вебер 1922. године наводећи да животни стил појединца може бити индивидуалистички, каријеристички или хедонистички.
} 
избор). Теоретски оквир неокласичног економског приступа развијен је деведесетих година двадесетог века у тзв. нову економију о миграцијама домаћинства, где се сматра да се одлуке о миграцији доносе у склопу породице или домаһинства. За разлику од неокласичног приступа бихевиорални приступ стављь нагласак на мигранта, а не на место, сматрајући да су привлачност и одбојност насеља полазишта и одредишта миграција различито вредноване од стране миграната у зависности од њихових социоекономских и демографских обележја и породичног статуса. Неокласичне и бихевиоралне перспективе у миграционим проучавањима у новије време су замењене структурним и институционалним приступима у којима је веһа пажња усмерена на активну улогу коју имају државне политике и послодавци у формирању и обликовању миграционих могуһности и путања каријере свог особља. Акценат је на тврдњи да процеси просторне мобилности и реструктуирање тржишта рада треба да се посматрају као интерактивни (Gordon, 1995, према Green A.E., T. Hogarth, R.E.Shackelton, 1999).

Бихевиорални приступ миграцијама третира миграцију као бихевиорални процес укључујући процесе прикупљања информација, доношења одлуке и асимилације. Хагерстранд даје концепт миграција као просторног процеса у друштву, посматрајући миграцију првенствено као резултат сазнања о другим просторима добијених путем информација (Hagerstrand, 1957 према Roseman С., 1971). На тип просторне покретљивости у великој мери утичу информације које становништво добија. Процес прикупљања информација од стране потенцијалних миграната одвија се у оквиру два простора: "простор активности" и "простор индиректног контакта". Простор активности домаћинства састоји се од оних локација са којима долази до директног контакта услед свакодневних активности. Овај простор укључује подручја најближа породици која разматра могућност миграције. То може бити простор већ укључен у седмична кретања домаћинства. Видети лично потенцијална места за пресељење резултира информацијама из прве руке. На супрот томе, индиректан контактни простор генерално није у оквиру или близу директно претраживог активног простора и прикупљање информација зависи од других људи или масовних медија (информација из друге руке) (Roseman C.,1971). За дневног мигранта простор свакодневних активности односи се на насеље рада, па у том случају, са повећањем количине информација, веома лако може доћи до дефинитивне миграције. Бројни истраживачи су приметили да је у многим земљама највећи број миграната већ посећивао место у које се преселио. Испитивањем миграната о извору првих информација о месту пресељења утврђено је да је једна четвртина живела близу места новог пресељења и у скорије време га посеһивала. "Више од $60 \%$ испитаника већ је посетило ново место становања пре него што је први пут помислило да се тамо пресели, а готово половина је имала пријатеље или родбину који живе у или у близини места пресељења у то време" (Jones Н., 1976). Информације из друге руке о потенцијалном месту одредишта мигрант добија путем медија путем или преко везе са тренутним или бившим мигрантима. Бројна истраживања показују да социјалне мреже смањују трошкове и ризик везан за миграцију, чинећи тако вероватнијим да дође до пресељења. Као што административнотериторијалне границе насеља нису границе његовог функционалног деловања, тако са деловањем медија и социјалних мрежа сфера контаката становништва није ограничена само границама насеља становања. Значај информација добијених индиректним путем већи је за становништво које не припада категорији дневних миграната, већ станује и ради у истом насељу.

Трошкови дневних миграција и објашњење миграција на основу уравнотежења понуде и потражње међу различитим тржиштима рада и некретнина, као и на основу фактора доступности запослењу, у центру су проучавања економиста и просторних планера. У контексту урбаних тржишта рада доступност се односи на број могућности 
за посао доступних у оквиру одређене дистанце времена потребног за путовање од куће до посла, док се мобилност односи на могућност пресељења са намером да се досегну ове пословне могућности. Јасно је да што је мања густина некретнина и послова на одређеном простору неопхдно је повећати мобилност у намери да се одржи доступност (Vandersmissen M.H., P.Villeneuve, M.Thériault,2003). Бројни аутори баве се испитивањем ефективности утицаја начина коришћења земљишта на доступност а тиме и на процес дневних миграција. Резултати ових испитивања су различити. На примеру Бостона нпр. доказано је да је урбана просторна структура детерминисана начином коришћења земљишта и транспортом и да има значајан ефекат на понашање радника у путовању, као и да је ефекат доступности запослења статистички веома значајан за време путовања дневног мигранта. Већи ниво доступности пословима кореспондира са нижим нивоима запажених дневних миграција. Доступност се може побољшати реконфигурисањем коришћења земљишта и повећањем брзине путовања (Shen Q,2000). На дефиницију Шена који урбану просторну структуру види као дистрибуцију људи и могућности за запослење треба додати и саобраћајну инфраструктуру преко које људи могу потенцијално досећи ове могућности (Vandersmissen M.H., P.Villeneuve, M.Theriault, 2003). Да начин коришћења земљишта утиче на понашање у путовању дневних миграната указује и Керверо (1989). На примеру 40 већих приградских центара запослења у САД показано је да је локална неравнотежа у односу послова и стамбеног простора присилила раднике да станују даље од места рада него што би иначе изабрали сами, чиме аутоматски више користе аутомобиле и повећавају загађење (Cervero,1989, prema Shen Q,2000). Ови аутори закључују да уколико су урбана подручја креирана тако просторно да су релативне локације послова у односу на места становања у одређеном подручју у просеку далеко једни од других, дневне миграције ће бити обимније него што би биле у компактнијем простору. Има и другачијих сазнања. Ђулијано и Смол су проучавали да ли су путање дневних миграција везане за урбану структуру. Анализом просечног времена путовања дневних миграната на примеру Лос Анђелеса утврдили су велике проширене дневне миграције, закључујући да трошкови дневне миграције нису главни фактор објашњења стварних путања дневних миграција. Ако би одабрали место становања најближе месту рада просечно време дневне миграције у Лос Анђелесу било би готово три пута мање од стварног (Giuliano G., K.A.Small,1993). Мере доступности обично дају информације о просторној раздвојености места рада и места становања, подразумевајући да је место становања полазиште и одредиште свих дневних активности. С обзиром да стандардне мере доступности не могу да обухвате индивидуалне карактеристике Вебер и Кван на примеру Портланда и Орегона користили су индивидуалне мере доступности појединца у времену и простору са вишеструким моделовањем да би се искључили ефекти појединачних нивоа варијације од утицаја географског контекста. Резултати су показали да доступност тежи да показује карактеристике појединца и домаћинстава пре него локалне урбане средине, те закључују да је употреба просторног планирања да би се утицало на доступност неадекватна. Као најважније за разумевање доступности истичу обележја пол, старост, расну припадност (Weber J., M.P.Kvan, 2003).

Питања о вези између обима и праваца дневних миграција, и урбаних форми такође су предмет проучавања бројних истраживача. Разматра се да ли промене урбане структуре из моноцентричне у полицентричну утичу на промене у временској и просторној компоненти дневне миграције и врсти превоза дневног мигранта. У литератури о утицају градске структуре на дневне миграције главно место заузима колокациона хипотеза оригинално формулисана од стране Гордона, Ричардсона и Јуна. Они су постулирали хипотезе колокације према којима домаћинства периодично мењају место становања и место рада, прилагођавајући се, како би избегли прекомерна 
свакодневна путовања. То им омогућава да путују краће и избегну загађење моноцентричних урбаних подручја. Исто је и са предузећима која мењају локацију да би се избегле високе цене закупа земљишта, ограничене могућности просторног ширења итд., што води ка развоју полицентризма и смањењу времена потребног за дневну миграцију (Gordon, Richardson, Jun,1991 према Shen Q, 2000). Левинсон и Кумар проширују претходну рационалну локациону хипотезу на послодавце који треба да се релоцирају како би остали довољно близу својој потенцијалној радној снази (Levinson D., A.Kumar,1994). Веза између урбане форме и временске и просторне димензије дневне миграције још увек није довољно разумљива, нарочито у мањим градовима, јер се веһина студија које разматрају ову проблематику односи на велика метрополитенска подручја где су услови у којима се одвија саобраһај прилично другачији од оних у мањим подручјима. Већина анализа о томе ко и колико времена проводи у дневним миграцијама базира се на односу централни град/предграђе. Различити су и резултати истраживања на ову тему. Шенон, Дилман и Дист су утврдили да је појединачна варијабилност у понашању дневних миграната већа од ефекта градске структуре. Њихово истраживање показује да урбана структура, премда значајно утиче на путање дневних миграција, објашњава само мали део варијација понашања дневних миграната. Друге студије дају супротне емпиријске закључке. Керверо и Ву на подручју Сан Франциска показују да се након развоја полицентризма повећала и временска и просторна дистанца дневне миграције. Доказано је такође да полицентризам није увек везан са већим коришћењем аутомобила као начина путовања до посла, као што се уобичајено мисли (Schwanen T., F.M.Dielman, M.Dijst, 2004).

Објашњење миграција само на основу економских фактора, уравнотежења понуде и потражње међу различитим тржиштима рада и некретнина, или просторних фактора све је мање адекватно, с обзиром на приметан растући значај бројних других детерминанти савремених миграционих токова. Виђење миграција као резултата процеса које се одвијају између појединца и друштвено-економске средине у оквиру које се они налазе утиче да се дневне миграције све чешће посматрају и у вези са дефинитивним миграцијама. Један од првих "комбинованих" теоретско-методолошких приступа миграцији, који повезује појединца и друштво, представио је Вилбур Зелински. Предложио је тзв. модел транзиције просторне мобилности, посматрајући динамику облика просторне покретљивости становништва у ширем оквиру социјалних, демографских и културних промена, а у вези са економским развојем и урбанизацијом. Процес друштвено-економског развоја води ка серији промена просторних путања мобилности становништва (миграционих транзиција) у складу са еволуцијом друштва. Ове промене крећу се од ограниченог степена готово свих облика мобилности, специфичног за традиционално друштво, затим следи фаза раног транзицијског друштва у којој се одвија масовна миграција правца село-град и знатан пораст обима циркулаторних кретања. У трећој фази касног транзицијског друштва миграција селоград се смањује док постају обимнија циркулаторна кретања. У четвртој фази развијеног друштва наставља се смањење обима миграција село-град и уббрзавају међуградска миграциона циркулаторна кретања. У задњој фази дефинитивне миграције се и даље смањују у обиму због пораста неких облика циркулаторних кретања и комуникација као и због могуће политичке контроле унутрашњих и међународних просторних кретања. Следи да транзицију у напредно друштво карактерише пораст циркулације становништва науштрб смањења обима дефинитивних миграција (Zelinski W.,1971).

Свиндел и Форд, покушавајући да обухвате све елементе у миграционом процесу, издвајају три основна елемента миграционих проучавања: места, мигранти и организација, који се могу даље разложити на њихове саставне делове. Миграција се 
посматра као функција места $\mathrm{S}$ и миграната $\mathrm{M}$ који се крећу између ових места помоћу организације О. Све три варијабле су условљене временом t. Ова веза се може изразити као $\mathrm{MIG}=\mathrm{f}^{\mathrm{C}}(\mathrm{S}, \mathrm{M}, \mathrm{O})$, односно свака миграција се може одредити скупом $\mathrm{G}$ где је $\mathrm{G}=\mathrm{t}(\mathrm{s}, \mathrm{m}, \mathrm{o})$, што даје $2^{3}$ комбинација. Укључивање времена као ограничења наглашава динамичку природу миграција.

Скуп места S дели се на локацију L, популацију $\mathrm{P}$, и функције $\mathrm{N}$. На основу тога места могу бити изражена као $S=f^{\prime}(L, P, N)$. Места одликује њихова трајна популација $P$ у одређеном временском периоду t, што заједно са њиховим функцијама $\mathrm{N}$ чини хијерархију места. Саставни делови популације P су r - број, f - демографски састав и $\mathrm{m}$ - статус мобилности популације. Тако се популација места $\mathrm{S}$ може представити као $\mathrm{P}=\mathrm{f}^{\mathrm{t}}$ $(\mathrm{r}, \mathrm{f}, \mathrm{m})$ Елементи популације су динамички и мењају се с временом. Статус мобилности становништва m односи се на аутохтоно и алохтоно становништво.

Скуп миграната М може се разложити на: тип мигранта - Y, демографске карактеристике мигранта - E и циљеве - J, односно $\mathrm{M}=\mathrm{f}^{\prime}(\mathrm{Y}, \mathrm{E}, \mathrm{J})$. Сваки од ова три елемента може се даље разложити, тип мигранта на а и $b$, односно први пут мигранте и повратне мигранте, а као додатна компонента се може додати зависност d. Тип миграната може се изразити као $\mathrm{Y}=\mathrm{f}^{\prime}(\mathrm{a}, \mathrm{b}, \mathrm{d})$. Демографске карактеристике $\mathrm{E}$ могу даље бити разложене на број кретања - n, пол - $\mathrm{x}$, старост - 3 и социоекономски статус - u. Стога се демографске карактеристике миграната могу приказати у облику израза $E=f^{f}$ $(\mathrm{n}, \mathrm{x}, \mathrm{z}, \mathrm{u})$. Трећи елемент скупа миграната - циљеви J садржи бихевиоралне карактеристике - атрибуте понашања појединца односно иницијативе предности могуhе дестинације и одлуке о повратку у место порекла. Циљеви се могу посматрати као функција образовања -е, технолошког нивоа - $\mathrm{t}$ и економске фазе развоја - $\mathrm{s}$, односно $\mathrm{J}=\mathrm{f}^{\mathrm{t}}(\mathrm{e}, \mathrm{t}, \mathrm{s})$. Циљеви су поред напред наведеног везани и за демографске карактеристике Е и саме мигранте М.

Табела 1. Основни елементи мигращионог процеса

\begin{tabular}{|c|c|c|c|c|c|c|c|c|}
\hline \multicolumn{9}{|c|}{ Основни исказ $\mathrm{MIG}=\mathrm{f}^{2}(\mathrm{~S}, \mathrm{M}, \mathrm{O})$} \\
\hline Елементи & \multicolumn{3}{|c|}{ Места (S) } & \multicolumn{3}{|c|}{ Мигранти (M) } & \multicolumn{2}{|c|}{ Организације (0) } \\
\hline $\begin{array}{c}\text { Преа фаза } \\
\text { дисагрегације }\end{array}$ & $\begin{array}{c}\text { Локација } \\
\text { (L) }\end{array}$ & $\begin{array}{l}\text { Популација } \\
\text { (P) }\end{array}$ & $\begin{array}{l}\text { Функкције } \\
\text { (N) }\end{array}$ & $\begin{array}{l}\text { Tun } \\
(Y)\end{array}$ & $\begin{array}{l}\text { मемографске } \\
\text { карактеристике } \\
\text { (E) }\end{array}$ & $\begin{array}{l}\text { Чиљеви } \\
\text { (J) }\end{array}$ & $\begin{array}{l}\text { Формалне } \\
\text { (F) }\end{array}$ & $\begin{array}{l}\text { Неформалне } \\
\text { (I) }\end{array}$ \\
\hline $\begin{array}{c}\text { Аруга фаза } \\
\text { дисагрегације }\end{array}$ & & $\begin{array}{c}\text { Број } \\
\text { Демографске } \\
\text { карактеристике } \\
\text { Миграциони } \\
\text { статус }\end{array}$ & & $\begin{array}{l}\text { Први пут } \\
\text { мигранти } \\
\text { Повратни } \\
\text { мигранти } \\
\text { Зависни } \\
\text { мигранти }\end{array}$ & $\begin{array}{c}\text { Број } \\
\text { Пол } \\
\text { Cтарост } \\
\text { Cоциоекономски } \\
\text { статус }\end{array}$ & $\begin{array}{l}\text { Образовни } \\
\text { ниво } \\
\text { Фаза } \\
\text { економског } \\
\text { развоја }\end{array}$ & $\begin{array}{l}\text { Државне } \\
\text { Приватне } \\
\text { Hecpehe }\end{array}$ & $\begin{array}{c}\text { Сродство } \\
\text { Етничка } \\
\text { припадност } \\
\text { Развод } \\
\text { брака и сл. }\end{array}$ \\
\hline
\end{tabular}

Swindell K., R. Ford,1975.

Одлука о миграцији зависи од социоекономске средине друштва у коме појединци живе и одређених тачака у њиховом животном циклусу. Скуп Миграната М и Циљеви $\mathrm{J}$ нису једине детерминанте типа, обима и праваца миграционих токова, премда су веома значајне. Ове варијабле су ендогени фактори, с обзиром да су више везане за саме мигранте, док је други скуп фактора (O) егзогени. Ови фактори су названи организациони - O, и подразумевају скуп утицаја формалних и неформалних организација, који могу олакшати или контролисати миграције становништва између места.

Скуп O дели се на F формалне организације (састоји се из елемената $\mathrm{g}$ државни, q -приватни и $\mathrm{H}$ - опасност) и неформалне организације, односно $\mathrm{F}=\mathrm{f}^{\mathrm{t}}(\mathrm{g}, \mathrm{q}, \mathrm{H})$. Утицај влада на промовисање одређених радних или популационих политика у неким местима подразумева - g, q - представља утицај пословне политике предузећа, а Н утицај природних катастрофа, ратова или политичких подела. Неформалне 
организације представљају значајну помоћ и асистенцију токовима миграната преко породичних и родбинских веза. Овај приступ омогућава довођење у везу различитих типова миграције, прилагођавањем дефиниције временског периода дневним или другим кретањима (Swindell K., R.Ford,1975).

Са теоретско-методолошког аспекта, једнако као што је важна веза између миграција и друштва, односно услови у којима се миграције одвијају, за одвијање миграција важни су и фаза животног циклуса појединца, на коју указују одређена обележја као што су брачно стање и родитељство, и друге демографске и социоекономске карактеристике појединца и домаћинства. Ови параметри заједно доприносе објашњењу варијабилности миграционих токова унутар неког подручја. Утврдити како долази до одлуке о миграцији, и избора одређеног типа миграције (дневна, дефинитивна и др.) и насеља одредишта, веома је важно за разумевање миграционих процеса. Савремена литература која се бави проблематиком миграција препуна је доказа о растуһем значају животног стила и фактора квалитета живота за избор типа миграције и места одредишта. Биолошка путања различитих делова живота појединца састоји се из различитих животних аспеката као што су аспекти родитеља или партнера, радни аспект и аспект куһе. Сваки аспект, премда има сопствену динамику, утиче и на друге. Камстра нпр. прави разлику разлику између радног и породичног стила (Camstra R.,1996). Значај животног стила нарочито долази до изражаја у вези са контраурбанизацијом и запаженим повећањем обима дефинитивних миграција правца град-село, као и повећаним обимом дневних миграција супротног смера у бројним развијеним земљама. Постоје две супротстављене хипотезе у литератури које се односе на детерминанте промене смера миграционих токова. То су хипотеза регионалног преструктуирања и хипотеза деконцентрачије. Ове две хипотезе показују суштинску разлику између економских и бихевиоралних схватања процеса миграције. Према хипотези регионалног преструктуирања промене у правцима дневних миграција и промене у урбаној просторној структури, као што је полицентричност, део су транзиције из индустријске у информациону економију (Van der Laan L., 1998). Према хипотези деконцентрације доминантна сила која је утицала на тренд у просторном размештају становништва западноевропских и северноамеричких земаља, у току последње две деценије, била је ексурбанизација везана за промене у преференцијама места становања (Renkow M., D.Hoover,2000). Томе су у знатној мери допринели бројни негативни ефекти урбаног развоја.

Имајући у виду значај фазе животног циклуса у миграционом процесу новији приступи у проучавању просторне покретљивости становништва покушавају да обједине микро и макро приступ миграцијама схватајући појединца као члана породице/домаћинства, а затим и као припадника одређеног друштва. Све је заступљеније становиште да се одлуке о миграцију, њеном типу, и избору места одредишта доносе у оквиру породице или домаћинства, имајући у виду не само економске веһ и бројне друге факторе. "Миграција је активност чврсто везана за успех или неуспех иницијатива које преузима домаћинство током своје интеракције са социјалном, економском и политичком средином" (Wood C.,1982). Истраживачи су показали да је велики део породичних миграција привремене природе, сезонски и-или циркуларан. Анализа миграционих одлука на нивоу домаћинстава представља избор типа миграције као део стратегије домаћинства за распоређивање чланова домаћинства, јер појединац може бити само на једном месту и једно време, а чланови домаћинства могу комбиновати вишеструке локације, што подразумева да домаћинство мора да се састоји од најмање два економски активна члана. Ово је виђење миграција као непрекидног процеса размештаја радне снаге домаћинства (Brown D.L.,2002). Домаћинства додељују својој радној снази бројне локације као експлицитну и 
флексибилну стратегију за повећање укупних прихода домаћинства, као и за диверзификацију ризика везаног за концентрацију на једном месту и-или једном занимању (Stark O., E.Taylor, 1991). Одлука о мигращији за самца - самачко домаћинство погађа само појединца, док за домаһинство са више чланова одлука о миграцији (уколико је миграција дефинитивна) погађа и друге чланове домаћинства тзв, пасивне мигранте. Испитивања бројних миграционих кретања открила су да је велики број миграната зависан од релативно малог броја миграната, које Хагерстранд назива пасивним мигрантима. Ово становиште веома је важно за разумевање дневних миграција активног становништва, где дневна миграција једног члана домаһинства може бити наменски избор да би се заштитили остали чланови домаћинства од дефинитивног пресељења које би проузроковало прекидање социјалних веза у насељу становања и захтевало асимилацију у насељу одредишта. На тај начин радник помоћу дневне миграције, прилагођавајући само неке аспекте живота, постаје независан од локалних економских услова. Истраживања показују да са датим позитивним трошковима пресељења, домаћинства са мањом вероватноћом мењају место пребивалишта и рада у оквиру датог географског региона него што само мењају место пребивалишта или место рада (Zax J.,1994). Један од представника приступа који желе да обухвате и микро и макро аспект миграционог процеса је Ричмонд. Он представља мултиваријантни модел који баца светло на интеракцију измећу друштвених фактора и домаћинстава. "Друштвени фактори могу како ограничавати тако и поспешивати акцију домаһинства" (Richmond 1994, према McDowell C., A.de Haan, 1997).

Када је реч о поменутој проблематици у страној литератури најчешће налазимо израз household - домаһинство, па ипак "у савременим условима живота, где се домаћинство свело претежно на нуклеарну породицу, нема потребе за разликовањем међу домаћинством и породицом". Мацура још шездесетих година прошлог века увиђа значај проучавања на мезонивоу говорећи о тзв. демографији породице која и садржински и методолошки може да представља другојачији а можда и адекватнији приступ проучавању демографских феномена. "Демографија породице је ствар будућности” (Мацура М.,1974).

\section{5. Дефиниција дневне миграције, положај дневних миграција у миграционим типологијама и типологија дневних миграната}

Сложеност миграционог процеса и мултидисциплинарност приступа проучавања проблематике дневних миграција одражава се у постојању различитих дефиниција дневне миграције. С обзиром да дневна миграција не значи и промену места боравка поставља се питање да ли је дневна миграција уопште миграција и како је дефинисати. Дефиниција дневне миграције треба да садржи сву комплексност двосмерне везе између места становања и места школовања/рада, указујући да је "дневна миграција посебан облик просторне и друштвене покретљивости дела активног и уз њега везаног становништва" (Фригановић, 1978).

Различите типологије миграција, које садрже дневне миграције, доприносе теоретским сазнањима о овом облику просторне покретљивости становништва. За категоризацију миграција као дневних најчешһе се користи критеријум времена. Другостепени критеријум је територијални домет миграције, подразумевајући раздаљину између насеља становања и насеља рада коју је могуће свакодневно прелазити.

Положај дневних миграција у миграционој типологији везан је за одредницу времена трајања (учесталост) миграције. Миграције се према времену трајања најчешће 
деле на дефинитивне - трајне, сезонске - повремене, седмичне и дневне миграције. Дневне и седмичне миграције подразумевају дневни или седмични одлазак радника (или активних лица уопште) на посао; такође свакодневни или седмични одлазак ђака и студената ради похађања наставе (Брезник Д.,1980;CDI-IDN,1971). Подразумева се да свакодневно путовање до другог насеља захтева више времена од оног које би било потребно да особа ради/школује се у истом насељу, али такође и да се не путује превише далеко да се дневни мигрант свакодневно не може вратити у насеље становања. “Дневне миграције тј. дневно одлажење радника из места живљења у место рада подразумевају кретања радне снаге на мањим одстојањима, која се у одговарајућим саобраћајним условима и приликама могу савладати у оквиру разумног продужења радног дана за онолико времена колико је потребно раднику за путовање на рад“ (Мацура М.,1965). Неки аутори дефинишу дневну миграцију као облик просторне покретљивости становништва где путовање траје више/мање од одређеног времена. У Италији се за границу дефиниције дневног мигранта узима трајање путовања у једном правцу дуже од 20 минута (Costa G., L. Pickup, V. Di Martino 1988). Свиндел и Форд сматрају да је дневна миграција облик привремене миграције а подразумева дневно кретање радне снаге од места сталног боравка до места рада и обрнуто. Да би се издвојиле дневне миграције као параметар предлажу одсуствовање од куће које траје краће од 24 сата. То аутоматски издваја дневне миграције од других облика мобилности (Swindell K., R.Ford,1975).

Често се под дневним мигрантима сматра становништво које станује и школује ce/ради у различитим административним јединицама, те приликом путовања свакодневно прелази одређену административну границу (различитог ранга). Дикинсон назива дневним мигрантима оно активно становништво које свакодневно приликом путовања на посао прелази административну границу најнижег ранга (Dickinson R.E., 1957). Ова дефиниција дневног мигранта, поред критеријума учесталости кретања, званично је прихваћена и у нашој земљи и користи се приликом спровођења пописа становништва, као параметар за категоризацију лица у дневне мигранте. "Дневни мигранти су лица која раде или се школују ван места свог сталног становања али се више пута током једне седмице у њега враһају" (РЗС,2004). Када је реч о административној граници, као и други облици просторне покретљивости становништва, дневне миграције могу бити унутрашње и вањске, у зависности од тога да ли дневни мигрант свакодневно прелази границу одређене територије.

С обзиром на интервал трајања миграције Вертхајмер-Балетић миграције дели на:

а) дефинитивне (коначне) миграције, и

б) привремене у ширем смислу, које могу бити: $\left.\sigma_{1}\right)$ привремене у ужем смислу, $\sigma_{2}$ ) сезонске, $\sigma_{3}$ ) дневне миграције.

Привремена миграција у ширем смислу обухвата првенствено радну снагу која мигрира привремено, тј. на одређено време, сезонски или дневно, и то из економских разлога у другу државу или у друга подручја исте земље. Привремена миграција у ужем смислу најчешһе се односи на привремени рад у иностранству. Сезонска миграција подразумева миграцију радне снаге из подручја сталног боравка у подручје рада 360 сезонског запослења. Дневна миграција је трећи облик привремене миграције у ширем смислу. Овај вид миграције подразумева дневно путовање радне снаге од места сталног боравка до радног места и назад (Wertheimer - Baletić, 1982).

У литератури се јавља и подела миграција на миграцију (у ужем смислу) и циркулацију - кружно кретање које се увек враћа у место поласка (дневна, седмична, сезонска). За циркулацију се употребљавају још и називи commuting (енг. промена смера) и pendulation (лат. пендуларе, њихати се) и овај облик кретања обухвата све 
облике просторне покретљивости становништва осим дефинитивне миграције (Roca O., 1986). Према трајању миграције Скелдон (Skeldon R.,1977) издваја три општа типа миграција становништва: семиперманентне-полутрајне, пендуларне и перманентнетрајне. Семиперманентне миграције односе се на дуже одсуство из насеља становања, које може бити чак и неколико година. Пендуларне миграције односе се на краћа одсуствовања из насеља становања. У случају ових миграција мигранти имају одређени циљ због кога долази до одсуствовања из насеља становања и то одсуство није дуже од три месеца. Ова два типа миграција су циркулаторна - кружна. Трећи тип миграција су трајне миграције, где се трајно мења насеље становања. Као други критеријум дефинисања миграције, поред времена трајања, користи се територијални домет миграције, и на основу тога разликују миграције на краһе и дуже раздаљине. Миграције на краће дистанце су оне где је кретање у оквиру сфере утицаја најближег главног града региона, док су миграције на дуже дистанце ван ове сфере утицаја. Сва три типа миграција према трајању могу припадати и једној и другој групи миграција према територијалном домету, премда су пендуларне миграције претежно на краће дистанце. Ове просторне и временске путање у комбинацији формирају дефинитивну структуру миграција која варира систематски у простору и времену како процес урбанизације еволуира (Skeldon R.,1977). Према претходној типологији дневне миграције су пендуларне - циркулаторне миграције на краће дистанце. Сличну типологију просторне покретљивости становништва засновану на критеријумима времена и учесталости, предлаже Роца (Roca O., 1986). У оквиру ове типологије, дневне миграције налазе се у категорији редовног-дневног просторног кружног кретања (циркулације), чија је учесталост враћања у место сталног становања дневна. Територијална мобилност становништва дели се на две категорије:

- миграције (могу бити коначне и привремене (краткотрајне и дуготрајне)). Свака од ових категорија дели се на повратне и поновне миграције;

- просторно кружно кретање (ұиркулација), које је сваки одлазак из места сталног становања у друго место, те његов повратак. Дели се на редовну, случајну и сезонску чиркулачију.

Редовна ииркулаиија подразумева редовна кретања између места сталног становања и другог места (ради посла, школовања), а учесталост враћања у место сталног становања може бити дневна, седмична или ређа односно повремена.

Случајна кружсна кретањ $а$ укључују сваки нередован одлазак из места сталног становања у неко друго место (ради рада на грађевини, одслужења војног рока и сл.) и повратак након неког одређеног времена. Одсутност може бити једнократна или вишекратна што значи да се становник може више пута враһати у своје место у току одсутности.

Сезонска чиркулачија одвија се у току одређених годишњих доба и везана је за потражњу радне снаге за обављање сезонских послова. Обухвата једнократне или вишекратне повратке у место сталног становања.

Други критеријум предложене типологије јесте територијални домет (удаљеност између два места) просторне покретљивости. На основу овог критеријума миграције су подељене у четири категорије локалне, међуопитинске, међурепубличко-покрајинске и међународне. Сваки од ових типова има два подтипа (краћи и дужи домет) у зависности од тога да ли се миграција односно циркулација одвија између суседних административно-територијалних јединица или просторних јединица које се не граниче (Roca O., 1986).

На комплексност дефиниције дневне миграције указује и чињеница да социолози сматрају да се особа која остаје у оквирима исте социјалне мреже не може сматрати 
мигрантом. Розман нпр. разликује делимично и потпуно пресељење у зависности од тога да ли се недељни циклус кретања у потпуности или делимично мења. Већина реципрочних кретања, међу којим је и дневна миграција, понављају се са одређеном учесталошћу, често у редовним интервалима, док је миграција мање честа (Roseman C., 1971). Са тог аспекта веома је интересантна класификација просторне покретљивости становништва коју је предложио Сфорца (Cavalli-Sforza,1962, према Roseman C., 1971). Ова типологија претпоставља постојање две главне категорије кретања. Прва категорија укључује реципрочно кретање појединца које почиње од куће, наставља ка једној или више специфичних локација и враћа се кући. Реципрочни циклус кретања се дефинише сумом свих реципрочних кретања особе током одређеног периода времена. Постоји неколико нодова или места заустављања у циклусу појединца, укључујући и кућу, место рада, место набавке и локације других активности. Међу овим нодовима кућа је, према Хагерстранду, центар гравитације од највећег значаја с обзиром да се сва кретања у циклусу редовно тамо враћају, док се други нодови посећују са мањом учесталошћу. Многи нодови у одређеним циклусима се посећују дневно, седмично, месечно, у правилним временским интервалима док се други нередовно посећују.

Комбинација индивидуалних реципрочних форми кретања свих чланова домаћинства чини реципрочни циклус кретања домаћинства. Премда овакав циклус може бити дефинисан за било који временски интервал, недељни период је узет као адекватан, због значаја недеље као временске одреднице многих активности. Путовања која имају јак утицај на домаһинства су путовања на посао, у школу, набавку, док су многа ређа путовања искључена. Од централног значаја је циклус кретања за цело домаһинство током недељног периода, који је назван недељни миграциони циклус (Сл.1.).

Слика 1. Недељни циклус кретања

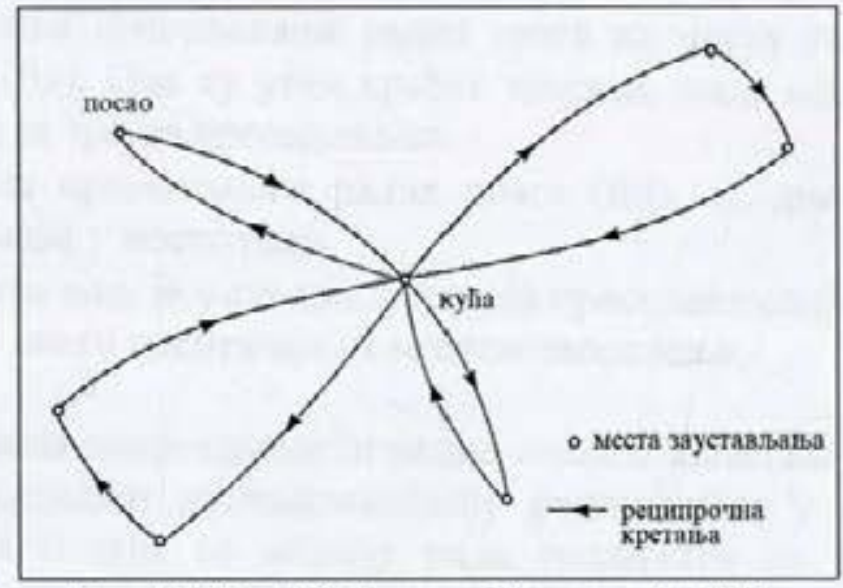

Cavalli-Sforza,1962, према Roseman C., 1971.

Насупрот овим реципрочним кретањима, људска пресељења која су у једном правцу и релативно трајна су друга главна категорија кретања. Ова кретања се дефинишу као миграција и представљају уклањање центра гравитације седмичног миграционог циклуса (куће) на нову локацију. Сваки преокрет у месту становања третира се као миграција, јер промена најчешһе посећиваног нода у циклусу - куће, проузрокује значајне просторне модификације седмичног циклуса кретања (Сл.2.).

Разлика између два наведена типа кретања није само у њиховој форми веһ и у учесталости. Већина реципрочних кретања понављају се са одређеном учесталошћу, често у редовним интервалима, док је миграција мање честа. Прави се разлика између делимичног и потпуног пресељења, у зависности од тога да ли се недељни циклус 
кретања у потпуности или делимично мења. За потпуно пресељење најкритичнији је фактор могућности за запослење, док на делимично пресељење делују углавном фактори домаћинства (Cavalli-Sforza, 1962 према Roseman C., 1971). Према овој подели просторне покретљивости становништва, дневне миграције представљају реципрочно дневно кретање, на које пресудан утицај имају фактори домаћинства.

Слика 2. Недељни циклус кретања и миграција

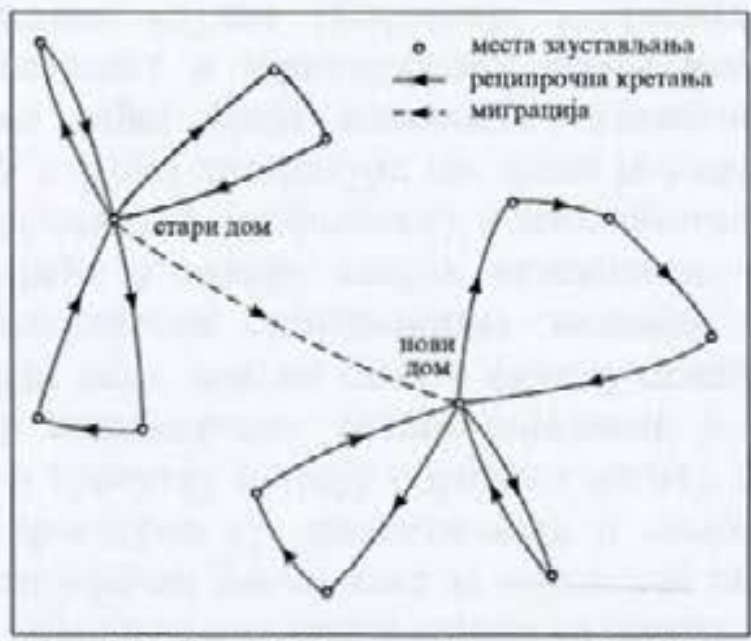

Cavalli-Sforza,1962 npeмa Roseman C., 1971.

Када је реч о типовима покретљивости радне снаге, Мацура издваја четири основна типа просторне покретљивости, економски мотивисане, радне снаге. То су:

- Трајна пресељавања радне снаге (Rt) из ранијег у ново место рада. По правилу ова се пресељавања могу идентификовати са пресељавањима на дужа одстојања.

- Сезонска пресељавања радне снаге из места сталног живљења у место рада (Rs). Она су увек краћег трајања, мада могу да буду и припремни корак за трајна пресељавања.

- Дневна пресељавања радне снаге (Rd), тj. дневно одлажење из места живљења у место рада.

- Четврти тип, је у ствари, негација пресељавања (Ra) јер је место живљења радне снаге идентично са местом запослења.

Од осам модела покретљивости радне снаге и капитала које издваја Мацура М. шести модел је условљен расположивошћу радне снаге у близини места рада. У зависности од тога о ком се моделу ради различити су и друштвени трошкови покретљивости капитала и радне снаге. Код модела који се заснива на дневним миграцијама радне снаге друштвени трошкови се минимизирају уколико се дневне миграције крећу ка привредно већим развијеним подручјима, у којима постоји саобраћајна мрежа и други видови инфраструктуре (Мацура М., 1965).

Пољски географ Гавризенски израдио је типологију миграција у којој повезује дефинитивне миграције са дневним миграцијама радника са села у град. Ова веза је динамичка и указује на то како један тип просторне покретљивости становништва може заменити други. Издваја три основна типа просторне покретљивости становништва, при чему други и трећи тип просторне покретљивости становништва обухватају везу између дневне и дефинитивне миграције:

- коначна миграција из места порекла А у директно изабрано ново место дефинитивног становања Б, 
- одлажење на посао у изабрано место становања Б из места порекла А (замена за дефинитивну миграцију),

- коначна миграција из места А у неко место Ц и одлажење на посао у изабрано ново место дефинитивног становања В које није далеко од места Ц док пресељење у место Б не постане могуhе (Gawryszenski 1978, према Roca O., 1986).

Напред представљене научне типологије миграција најчешће користе као критеријуме време, учесталост и територијални домет миграције. У новије време присутно је разматрање већег броја елемената приликом класификације типова миграционих кретања. У страној литератури све више је уместо миграција у употреби термин просторна покретљивост (мобилност) становништва, имајући у виду да се становништво стално креће у оквиру својих активности. Сток (2005) представља приступ географској мобилности становништва заснован на пракси, дефинишући праксу као оно што људи раде, али не само у смислу обављања рутинских послова. Свака пракса има своју индивидуалну (сваки појединац је специфичан), временску (одвијају се у одређеном тренутку и трају одређено време), просторну (обављају се у одређеним местима и просторно су оријентисане), и симболичку димензију (свака пракса има одређени специфичан значај како за појединца тако и за друштво). Два су основна критеријума за објашњење услова у којима се одвија кретање становништва: 1) дневно/не дневно кретање, 2) избор/обавеза. Три додатна критеријума представљају везу коју појединац успоставља са местом обављања праксе и карактеристике тог места (породично-непородично, близу-далеко, егзотично-неегзотично). Прва два критеријума, практично заснованог приступа мобилности, су од великог значаја за класификацију, док други елементи могу да варирају (Stock M., P.Duhamel, 2005). На основу комбинација ових критеријума свакодневна обавеза је оно што карактерише дневне миграције активног становништва.

Табела 2. Типологија просторне покретљивости становништва према приступу заснованом на пракси

\begin{tabular}{|c|c|c|}
\hline Пракса & Аневно & Не-дневно \\
\hline не-рутинска пракса (рекреација) & рекреација & туризам \\
\hline рутинска пракса (посао) & дневне миграције & пословна путоеана, конгреси \\
\hline
\end{tabular}

Stock M.,P. Duhamel, 2005.

У односу на просторну оријентацију дневних миграција у литературу су уведене различите врсте дневних миграција. Хамилтон уводи појам “бескорисних" (wastefull) дневних миграција указујући да емпиријски докази указују супротно претпоставци да су предвиђене путање дневних миграција оне које своде на минимум дистанцу путовања радника (Hamilton B.W., A. Roell,1982). Проширене дневне миграције (extended) становништва (подразумевају кретање радника преко граница округа из неметрополитанских ка метрополитанском подручју). Обим проширених дневних миграција прихваһен је као основна мера експанзије подручја метрополе у међуметрополитанску периферију или она подручја која се налазе између метро центара (Taaffe E.et al.,1980; Fisher J., R.Mitchelson,1981). Сувишне дневне миграције (excess commuting) су дневне миграције већег обима од процењеног теоретског минимума за одређено место (Scott et all.,1997, према Horner M.W.,2004). 
у типологији дневних миграната према различитим критеријумима честа је подела на аутохтоне и алохтоне дневне мигранте. Аутохтони дневни мигранти су они чије је место становања било исто и пре дневне миграције. Овај тип мигранта у првим облицима дневних миграција највише се односио на становништво рођено на селу, које је задржало свој пољопривредни посед и свакодневно путовало на посао у град. Алохтони дневни мигранти су се преселили из града и станују у његовој околини а свакодневно путују у град на посао. Они се повезују са процесом пораста броја становника урбаног центра (Dickinson R.E., 1957). Аутохтони и алохтони дневни мигранти, одговарају социјалним групама дневних миграната (традиционалној и мобилној) које је издвојио Фригановић. Традиционална група је претежно везана за кућу и пољопривредни посед и углавном је неквалификована радна снага. Њихово насеље становања припада лабилним просторима дневне миграције радне снаге и код млађих чланова породице јавља се жеља за преласком у град. Мобилна група дневних миграната је много покретљивија, и живи у насељима приградских стабилних простора дневне миграције (Friganović M., 1970). Користећи критеријуме стручне квалификације, стандарда коришћених саобраћајних средстава и просечног дохотка Жуљић дели дневне мигранте на две категорије: мигранте вишег стандарда и мигранте нижег стандарда, зависно од тога да ли је просечан животни стандард мигранта виши или нижи од просека за стално становништво у гравитационом центру. Сматра да је други тип у целини био карактеристичан за бившу Југославију (Žuljić S., 1970).

Поред поделе на аутохтоне и алохтоне честа је подела дневних миграната на приградске, изванградске и вањске дневне мигранте. Дневно путовање прве две групе у град или центар града првенствено је везано за избор места становања, док су вањски дневни мигранти, било да су са села или из другог града, одраз просторне неравнотеже на тржишту радне снаге и неодговарајућег размештаја радне снаге у односу на могућности запослења. Прве две категорије дневних миграната чини алохтоно становништво, док трећу категорију чини аутохтоно становништво.

Типологија дневних миграната Холмса заснива се на двојном критеријуму места пребивалишта и социјалне оријентације у односу на место рада, за које се у овом случају претпоставља да је град. Издвојене су три врсте дневних миграната (приградски, изванградски и вањски). Разлике између типова дневних миграната су у дужини путовања између насеља рада и насеља становања, али такође и у мотивацији и структури дневних миграната према различитим обележјима. Приградски и изванградски дневни мигранти оријентисани су према граду, док су спољни дневни мигранти оријентисани ван места рада и по месту становања, и по социјалној оријентацији. Ове дневне миграције радне снаге из сеоских подручја или других мањих градова у град обезбеђују само незнатан део градске радне снаге, претежно неквалификоване (Holmes J., 1971).

Табела 3. Типологија дневних миграната на основу локације места становања и социјалне оријентације

\begin{tabular}{|c|c|c|}
\hline \multirow{2}{*}{ Социјална оријентација } & \multicolumn{2}{|c|}{ Место станована } \\
\cline { 2 - 3 } & Град & Изван града \\
\hline Ка граду (Intraurban) & Приградски (Suburbanite) & Изванградски (Exurbanite) \\
\hline Ван града (Extraurban) & - & Вански (Extemal Commuter) \\
\hline
\end{tabular}

Holmes J., 1971.

Измењену варијанту ове типологије прилагођену просторима бивше Југославије представила је Роца (Roca O., 1986), користећи за дневне мигранте назив комутанти. На 
основу географског положаја домаћинства комутанта у односу на место рада, порекла комутанта у односу на место сталног становања те бављења или не двојном активношһу издваја два основна типа комутаната приградски (дневни) и изванградски.

Приградски дневни комутант живи у предграђу већег урбаног центра или метрополитанској регији. Већином су алохтони, јер су се преселили из централног у приградско насеље углавном због високих трошкова становања у централном насељу. Претежно раде у централном насељу и квалификовани су, службеници или стручњаци.

Изванградски комутант путује дневно, седмично или повремено. Бораве ван приградског подручја централног насеља рада а некад чак и изван регије у којој се налази место рада. Претежно су аутохтони, односно живели су у садашњем месту становања и пре него што су се определили за комутирање. Углавном су неквалификовани или полуквалификовани са малим примањима због чега се не пресељавају у место рада. Имају пољопривредно имање које им осигурава додатни извор прихода. Ово су традиционални сељаци радници комутанти за разлику од модерних сељака радника најчешће изванградских комутаната са специјализованом пољьпривредном производњом, који су претежно млађи и имају бољу квалификациону структуру од традиционалних сељака радника. Изванградски аутохтони комутант може бити и радник чије домаћинство нема додатних прихода од пољопривреде. Они претежно станују у неразвијеним подручјима где има мало могућности за запошљавање а немају ни земљу. Претежно су неквалификовани. Поред ових основних типова постоји и секундарни тип дневног мигранта тзв. аутохтони градски дневни комутант. Он станује у централном насељу и путује свакодневно на посао у приградско насеље било услед измештања места рада на периферију или неравнотеже у потражњи одређене радне снаге. Они су претежно висококвалификовани (Roca O., 1986).

Према овој категоризацији изванградски комутант, за разлику од претходно наведене типологије Холмса, је аутохтони а не алохтони и својом дефиницијом обухвата и вањске аутохтоне дневне мигранте. Ова разлика у типологији дневних миграната коју предлаже Роца, у односу на типологије америчких научника, резултат је разлика у мотивима дневних миграната. Савремене дневне миграције у нашој земљи и данас су резултат првенствено економских мотива и у њима већину чине изванградске и вањске (external commuting) дневне миграције аутохтоног становништва као главни начин прилагођавања просторној дистрибуцији могућности за запошљавање. Ове дневне миграције радне снаге из сеоских подручја чине већину у дневним миграционим токовима Србије, па и простора општине Панчево.

Канађанин Термоте предлаже типологију дневних миграната са циљем њиховог повезивања са дефинитивним миграцијама и процесом урбанизације. Представља три типа везе између дневне и дефинитивне миграције:

- Дневне миграције као замена за миграцију (дневне миграције из насеља Б у насеље А што смањује миграцију из насеља Б у насеље А );

- Дневне миграције као допуна миграцији:

- Ранији становници насеља А који су сада дневни мигранти из насеља Б у насеље A,

- Ранији становници насеља Ц који су сада дневни мигранти из насеља Б у насеље А, који би остали немигранти,

- Ранији становници насеља Ц који су дневни мигранти из насеља Б у насеље А, који би се иначе преселили у насеље A;

- Дневне миграције које имају неутрални ефекат на миграцију (становници насеља Б су дневни мигранти из насеља Б у насеље А, и иначе се никада не би дефинитивно преселили у друго насеље) (Termote 1980, према Roca O.,1986). 
Реитсма и Вергосен такође повезују дневну и дефинитивну миграцију, где дневне миграције представљају значајну условну везу између места рада и места становања. Мигранти су категорисани, према мотивима који генеришу миграционе токове, на радне, стамбене, и стамбено-радне. Радни мигранти су према истраживању знатно смањили време свакодневног путовања до посла након пресељења, док се за стамбене мигранте време путовања повећало. Мешовита група такође је имала смањење времена дневне миграције, што значи да су радни мотиви и у овој групи имали значајну улогу (Reitsma R., F.Vergoossen, 1987).

\section{6. Детерминанте дневних миграција}

Да би се разумео и правилно истраживао процес дневних миграција морају се размотрити и уважити сви фактори који подстичу кретање дневног мигранта утичући на појаву овог облика просторне покретљивости становништва. Много је лакше утврдити и анализирати обим и правце дневних миграција, и уопште свих типова просторне покретљивости становништва, него детерминанте које их узрокују. Фактори утицаја на миграциони процес су бројни и разноврсни, а значај утицаја појединих фактора зависи од карактеристика и циљева појединца и домаћинства дневног мигранта. Процес дневних миграција становништва стога се нужно мора посматрати као динамички у односу на простор и време у коме се одвија, јер се фактори утицаја али и степен утицаја одређених фактора на дневну миграцију могу мењати паралелно са променама услова живота и рада али и фаза у животном циклусу дневног мигранта и његових аспирација и вредоносних ставова. Свака промена у срединама становања и рада и структурним обележјима појединца и његовог домаћинства резултира променама у обиму, правцима и структури токова дневних миграција.

Да би уопште дошло до појаве и развоја дневних миграција услов је хетерогеност становништва и друштвено-економских услова у оквиру територијалне и временске дистанце која је погодна за одвијање дневних миграција. Што су социоекономске, демографске и друге разлике како подручја полазишта, тако и циљних подручја дневних миграција, али и становништва које их насељава веће, већа је и вероватноһа појаве дневне или других облика миграције. Који he фактор имати преовлађујући утицај на дневну миграцију, зависи како од обележја појединца, тако и од карактеристика сваког појединачног простора. У наставку је дата компаративна анализа досадашњих проучавања о факторима утицаја на процес дневних миграција, које аутори различито групишу у зависности од свог виђења овог феномена, а с обзиром на значајне варијације међу дневним мигрантима.

Фактори који обликују путање дневних миграција спадају у три категорије које се могу дефинисати као:

- фактори подручја (доступност и карактер послова - могућности за запослење, дистрибуција популације, популациона величина насеља, саобраћајни услови и природа и трошкови становања),

- лични фактори (запослени и њихове демографске карактеристике као што су пол, старост, брачни статус, степен образовања, дужина радног стажа, стамбени услови (сопствено власништво или подстанари) и обим делимичне ангажованости у пољопривреди), и

- индустријски фактори (тип индустрије, величина фабрике, њен положај у односу на стамбене зоне, висина зараде, услови рада и политика запошљавања). (Thompson J.H.,1956). 
Клеменчић географске факторе који утичу на процес дневне миграције дели по простору и значају на:

- факторе саобраћајно-географског значаја,

- факторе привредног центра, и

- факторе стамбених насеља или места становања (Klemenčcić V., 1962).

Фактори који утичу на дневну покретљивост радне снаге и на домет гравитационе зоне могу се класификовати као:

- рационални (зарада, социјално осигурање, трошкови становања, трошкови живота и др.),

- социјално-психолошки (нецењеност пољопривредног рада, преквалификација, тежња да се буде ближе граду и др.) (Friganović M., 1970).

С обзиром на релацију на којој се одвијају, односно чињеницу да чине везу између насеља рада и насеља становања, сматрамо да факторе утицаја на интензитет, правце и структурне карактеристике токова дневне миграције можемо поделити на:

- унутрашње (индивидуалне и факторе домаћинства), и

- спољашње (фактори тржишта рада, фактори тржишта становања, фактори саобраћајних услова и организације простора).

Спектар унутрашњих фактора утицаја на дневне миграције обухвата поред карактеристика појединца и домаћинства и личне/породичне социо-психолошке субјективне факторе миграције, који се односе на утицај фазе животног циклуса, аспирација, социјалних веза и личних/породичних циљева. Спољашњи фактори обухватили би економско-рационалне факторе и факторе простора. Унутрашњи фактори који утичу на дневне миграције су микро и мезо фактори релевантни за појединца и домаћинство, док су спољашњи фактори утицаја уствари макро фактори у вези са политиком економског и просторног развоја. Макро фактори утицаја на дневне миграције јесу управо они фактори који утичу на стварање регионалних разлика у различитим доменима, тиме управо подстичући дневне миграције као облик просторне покретљивости становништва.

Група унутрашњих фактора који делују на процес дневних миграција обухвата поред карактеристика појединца и домаһинства и личне/породичне социо-психолошке - субјективне факторе митрације, који се односе на утицај фазе животног циклуса, аспирација и јачине социјалних веза на понашања и ставове везане за дневне миграције (Lu M.,2002). Из перспективе деловања фактора животног циклуса на миграцију, која је потекла од Росија (1955), промене у животном циклусу које се односе на величину, старосни састав и социоекономски положај домаһинства утичу на захтеве за различитим типовима стамбене или географске локације што доводи до одлуке о миграцији. Старост је једна од најважнијих варијабли животног циклуса, при чему стопе мобилности достижу свој врхунац у млађим средовечним годинама. Фактор који се истиче као фактор стварања нових аспирација и блиско се везује за миграције јесте образовање. Степен образовања често води ка неким очекивањима која се могу реализовати само ван свог насеља становања, нарочито уколико се ради о сеоским насељима (Skeldon R.,1977). Уколико je становништво у сеоским насељима образованије већа је вероватноћа да һе доћи до дефинитивне миграције, јер тако потенцијални мигрант може остварити релативно висок доходак у граду, а ако је степен образовања нижи запослење у граду he бити допунско, а повремено или седмично путовање he преовладати (Conell и др., 1976, према Roca O., 1986). Биолошка обележја 
дневних миграната (пол, старост) али и нека социоекономска обележја, као што је брачни статус, најчешће се везују за фазу животног циклуса дневног миграната. За разлику од тога унутрашњи-индивидуални фактор дневне миграције који је веома битан јесте сектор делатности дневног мигранта. Сматра се да секторске карактеристике, професионалне карактеристике и висина зараде имају великог утицаја на тип просторне покретљивости становништва. Када је реч о дневним миграцијама доказано је да су ова обележја, поред обима дневне миграције у вези и са варијацијама просторне и временске дистанце дневне миграције. Утицај сектора делатности и занимања дневног мигранта на дистанцу путовања до посла одражава се на три начина:

- дневни мигранти који су у занимањима где се више зарађује путују свакодневно даље,

- дневни мигранти који раде у специјализованим занимањима путују даље,

- дневни мигранти запослени у индустријама које су по природи концентрисане на релативно малом броју локација путују даље, за разлику од просветних и здравствених радника којих има у готово свим насељима (Cristaldi F.,2005;Green A.E., T.Hogarth, R.E.Shackelton, 1999).

Стари типови индустрије у којима се мање зарађује имају ближу географску дистрибуцију радника него нови специјализовани типови индустрија где су зараде веће. Највеһа вероватноһа за дневну миграцију јесте код запослених у секторима који подразумевају велике фабрике као што је хемијска индустрија или метална и машинска индустрија. (Thompson J.H.,1956; Lu M.,2002). Тип индустрије и положај индустријских постројења у односу на стамбена насеља такође може утицати на обим и правце дневних миграција ако се ради о делатностима које имају негативне последице за животну средину насеља становања.

Економски мотиви најчешћи су разлог учешћа становништва у дневним и другим облицима миграција. Највећи број аутора истиче економске разлоге за појаву дневне и миграције уопште (понуда и потражња радне снаге, разлике у економским могућностима различитих простора, животни стандард и разлике у приходима). Економски фактори утицаја на дневне миграције могу бити привлачни (могућност стицања већег дохотка, боље могућности за запошљавање у струци, могућности специјализације), или одбојни (немогућност запослења или губитак посла у насељу становања, високе цене некретнина у насељу рада). Ови фактори су у директној вези са локалним и регионалним економским условима и условима на тржишту рада, у виду степена развијености и диверзификованости привреде, пораста или смањења потражње за одређеним занимањима и висине прихода. У зависности од економске структуре активног становништва свако подручје је специфично у погледу занимања за која локална привреда може да омогући запослење, што утиче на однос између места рада и места становања. Непостојање локалних потенцијала или њихова недовољна искоришћеност нужно узрокују већи обим дневних миграција становништва. Понекад промене у функцијама одређеног насеља и стању на локалном тржишту рада могу бити последица и одређених инвестиционих политика, што аутоматски изазива промене у интензитету, структури и правцима дневних токова активног становништва које обавља занимање.

Из перспективе послодавца промена места рада често се види као корисно средство напредовања особља и задовољења потреба организације посла. Такође и са становишта индивидуалног тржишта рада и перспективе каријере појединца промена места рада често нуди могућност развоја каријере коришћењем могућности које нису другде доступне (Green A.E., T.Hogarth, R.E.Shackelton,1999). То су примери деловања привлачних економских фактора на процес дневне миграције. 
Један од важних одбојних економских фактора утицаја на дневне миграције јесте незапосленост. Висока стопа незапослености у насељу становања узрокује већу конкурентност на локалном тржишту рада што може довести до повећаног обима дневних миграција активног становништва. Коришћење стопе незапослености као показатеља могућности за запослење у неком подручју потврдило је да за пораст стопе незапослености од $1 \%$ вероватноћа да дође до дневне миграције расте за $4 \%$. Економска специјализација различитих подручја такође утиче на процес дневне миграције. Најмању вероватноћу за учешћем становништва у дневној миграцији показују пољопривредни региони. У урбанизованијим и привредно развијенијим подручјима постоје разноврсни послови у односу на радну снагу па је овде и израженија појава дневне миграције (Artis M., J. Romani, J. Surinach,2000). Највећи удео унутрашњих дневних миграција у Италији има индустријски централни регион са хомогеном урбаном мрежом и дугом традицијом лаке индустрије (Cristaldi F.,2005). Сагласно напред наведеним истраживањима и други аутори су дошли до закључка да регион пребивалишта радника знатно утиче на путање дневне миграције. Резултати проучавања показују да доступност послова у окружењу (међурегионална доступност послова) и близина већих центара запошљавања значајно повећавају избор дневне миграције као модалитета мобилности становништва. Подразумева се да са повећањем токова информација и доступности послова, стопа пристизања понуда за посао расте, а трошкови дневне миграције се смањују. Ако је регион пребивалишта у близини главних градова региона већа је вероватноһа за дневну миграцију од просека (Rogers C., 1997).

Други економски фактор који утиче на настанак и развој дневних миграција, поред услова на тржишту рада, јесу услови на локалном и регионалном тржишту некретнина, Високе/ниске цене некретнина, стамбена политика или довољан/недовољьан обим стамбене градње у месту запослења/рада, могу утицати на избор облика просторне покретљивости становништва. Немогућност решења стамбеног статуса у насељу рада нпр. може утицати да се дефинитивна миграција замени дневном. Једна од често разматраних варијабли са могућим ефектом на дневне миграције јесте власништво стана/куће у насељу становања. Релативна непроменљивост места становања утиче на могућности запослења која су доступна на дневној удаљености од места становања (Hanson S., G.Pratt,1988). Истраживања упућују да власници стамбеног простора више од подстанара учествују у дневним миграцијама, јер подстанари могу лакше смањити своју просторну и временску дистанцу дневне миграције мењајући место пребивалишта ближе послу. Високе стопе незапослености и цене некретнина обесхрабрују како отказе тако и селидбе, односно радници су принуђени да задрже неоптималну комбинацију места рада и места становања на дужи рок. Друга хипотеза је да радници прихватају дуже дистанце путовања до посла у замену за веће јефтиније и боље опремљене куһе (Romani J., J.Surin, M. Artis, 2003; Lee B.S., J.McDonald, 2003). Истраживање дневних миграција у нашој земљи спроведено у Зрењанину и Нишу показало је да је преко $80 \%$ дневних миграната имало кућу или стан у власништву што је потврда сазнања о мањем учешћу подстанара у дневној миграцији (Прокић,1969, према Roca O.,1986).

Саобраћајни услови (доступност и развијеност саобраћајне мреже) су такође спољашњи фактор који подстиче или обесхрабрује дневне миграције, али и доприноси међурегионалним разликама у правцима и обиму дневних миграција. У изолованијим насељима са лошим саобраћајним везама дневне миграције одвијају се углавном локално. Као економска детерминанта дневних миграција сматра се и доступност аутомобила. Доступност аутомобила повеһава потенцијалну мобилност чланова домаћинства и такође може повећати њихов простор деловања омогућавајући дужа свакодневна путовања (Vandersmissen M.H.,P.Villeneuve,M.Thériault,2003). Ово је нпр. 
један од фактора утицаја на краће путање дневних миграција жена с обзиром да жене најчешће мање возе аутомобил него мушкарци.

Шездесетих и седамдесетих година прошлог века ниска зарада, углавном неквалификованих дневних миграната, утицала је на њихово бављење пољопривредом која им је била извор допунских прихода. Потенцијални мигранти лакше су се одлучивали за дефинитивно пресељење у град уколико нису имали земљу и могућност за алтернативу зараду коју је пружао рад на имању. Један од разлога за запошљавање сељака у непољопривредним делатностима, у ово време, била је и жеља за здравственим и осигурањем и остваривањем права на пензију. Делимична запосленост у пољопривреди у савременим животним условима све је мање разлог везаности актуелних дневних миграната за садашње место пребивалишта. Међутим породична и традиционална везаност за сеоско насеље и имање може утицати на избор дневне миграције, смера село-град, уместо дефинитивне миграције.

Међу спољним неекономским факторима дневне миграције, важну улогу у избору типа просторне покретљивости становништва и интензитету токова дневне миграције има организација простора. Организациони фактори подразумевају скуп утицаја који могу олакшати или контролисати миграције становништва између два насеља (Swindell K., R.Ford, 1975), Обим и правци дневне миграције умногоме зависе од густине мреже насеља и величине насеља. Величина града (мисли се на популациону величину) је један од фактора простора разматран као могући узрок варијација у путањама дневних миграција.?

Одлука о просторној покретљивости уопште, а самим тим и о дневној миграцији као једном од њених облика, све се више посматра као стратегија домаћинства него као потпуно индивидуалан избор (Skeldon R., 1977; Stark O., E.Taylor, 1991). Сматра се да је за потпуно пресељење најкритичнији фактор могућности за запослење, док на делимично пресељење делују претежно фактори домаћинства (Roseman C., 1971). Раздвојеност места рада од места становања може бити резултат личних (породичних) жеља или личних (породичних) егзистенцијалних потреба. У Србији су дневне миграције радника првенствено узроковане личним (породичним) потребама и имају економску оправданост, за разлику од дневних миграција радника у западноевропским земљама и Северној Америци, где су дневне миграције радника већ дуже време претежно резултат личних (породичних) жела за животом ван домета градске буке и аерозагађења (Лукић В.,2006).

Погодности животних услова један су од фактора утицаја на настанак и развој дневних миграција између два подручја. Поред стања на тржишту некретнина односно фактора трошкова становања, у земљама Северне Америке и западноевропским земљама запажен је растући значај фактора средине (квалитет животне средине) и услова становања (већа и опремљенија кућа) за појединца и домаћинство. Помоћу модалитета дневне миграције остварују се економске предности дневне миграције у смислу материјалног побољшања квалитета живота, уз становање у еколошки чистијем и здравијем насељу и бољем стамбеном простору. Избор еколошких услова живота још увек није доступан свима, и претежно се односи на становништво са већим примањима, које себи може да приушти да бира место становања. Овим променама у детерминантама дневне миграције развијених земаља допринео је и убрзан развој саобраћаја и саобраћајних средстава, као и промене на тржишту рада проузроковане глобализацијом и развојем информационих технологија које воде све веһој флексибилности по питању места рада и радног времена. Растући значај квалитета животне средине, проузрокован је вредносним ставовима појединца и домаћинства и

\footnotetext{
' Види Thompson, 1956.
} 
жељьм становништва за становањем у мање загађеној околини, наравно уколико то домаћинство може себи да приушти. "Уколико је квалитет живота у граду б већи од квалитета живота у граду $a$, висина зараде у граду $a$ мора бити већа да би компензовала лош квалитет живота" (Sun S., 1980).

Промене у значају деловања одређених узрочних фактора дневне миграције показују обим и правци дневних миграција. Иако веһина микроекономских теорија сугерише да свако тежи да сведе на минуму дистанцу дневне миграције у стварности када се посматрају домаћинства није баш тако. Половина запослених ван општине пребивалишта у региону Амстердама 1986. године желела је да се пресели, од чега само $15 \%$ ближе месту рада (Camstra R.,1996). Тренд повратка становништва у сеоска насеља нарочито је изражен у Енглеској и САД, што утиче на повећање броја становника у овим насељима. Сматра се да људи самовољно одлучују да поднесу терет додатног путовања до посла, у замену за живот на селу као супротност урбаном животу. У том случају стил живота преовладава у односу на економске факторе с обзиром да се путања дневне миграције у овом случају најчешће повећава (Renkow M., D.Hoower, 2000).

Поред фактора квалитета животне средине запажени тренд повећања броја дневних миграција на дужим релацијама доводи се везу и са социо-психолошким факторима везаности за породицу и друштво, односно чињеницом да дефинитивна миграција подразумева бројне промене за све чланове домаћинства нужно укључујући процес адаптације на нову средину. Везаност за локалну средину се често истиче као битан предуслов да не дође до дефинитивне миграције. Што је степен везаности појединца за локалну заједницу већи мања је вероватноћа да дође до дефинитивног пресељења, односно бира се модалитет дневне миграције. Д. Лајблинг и Е. Кинг из РАЦ Фондације испитивали су зашто дневни мигранти у Великој Британији путују све даље/на све већим релацијама. Утврдили су да већина људи станује у истој кући најмање десет година, те да постоји изразито смањење броја домаһинстава која се пресељавају због посла (између 1984. и 1994. године број ових домаћинстава се смањио за половину и и даље се смањује). Ово одражава утицај фактора као што су образовање деце, место рада другог запосленог у породици и унапређење саобраћаја које погодује путовањима на дужим релацијама. Више од половине радника дневних миграната на питање зашто се не преселе ближе месту рада одговорило је да су основни разлози ти што им се допада њихово тренутно место становања, те да су везани за породицу и пријатеље. Истраживање домаћинстава 2001. године у Америци показало је сличне резултате (Rac foundation, 2003; Nasser H.E.,2002).

У нашој земљи спољашњи економски и просторни фактори, као и у ранијим периодима, имају преовлађујући утицај на обим, правце и структуру дневних миграција, и представљају одраз неравномерног привредног развоја између насеља и општина, и изражене концентрације функција у појединим градским центрима. Високе трошкови становања и цене некретнина у насељима са веһим бројем функција и интензивном економском активношћу онемогућавају решавање стамбеног статуса у насељу рада, те је то најчешћи узрок избора дневне миграције као облика просторне покретљивости становништва.

\section{7. Временска и просторна димензија дневне миграције}

Време путовања до посла и просторна раздаљина коју дневни мигрант свакодневно пређе на релацији кућа - посао постају све значајнији у условима све веће саобраћајне гужве у градовима, и повећане буке и загађења ваздуха које саобраһај производи. Проучавање дистанце дневне миграције и времена које је за дневну 
миграцију потребно, доприноси како теоретским сазнањима о дневним миграцијама (колико је временски и просторно спреман да путује дневни мигрант у различитим околностима), тако и практичним потребама (да ли се може утицати на избор превозног средства и саобраћајне путање дневних миграната, а са циљем смањења саобраћајне гужве и честих и ванредних поправки најпрометнијих путева), као и за планирање проширивања саобраћајне мреже и возног парка јавног саобраћаја. Треба имати у виду и да је "дистанца дневне миграције важна детерминанта унутаррегионалних миграција", па су сазнања о временској и просторној димензији дневне миграције веома значајна и због тога веома битна (Zax J.,1994). Пораст свести о значају истраживања дневних миграција, услед бројних импликација за саобраһај које дневне миграције имају на локалном и регионалном нивоу, утицао је на спровођење анкета у бројним земљама о понашању дневних миграната у саобраћају, са циљем стварања одрживијих путања дневних миграција. Питања важна за планирање саобраћаја су да ли би се дневни мигранти преселили ближе послу уколико би се повећала загушеност саобраћаја, и да ли су и колико осетљиви на промене у времену које им је потребно за свакодневно путовање. Са тог аспекта временска и просторна дистанца дневне миграције ученика/студената нису толико значајне, с обзиром да они у нашој земљи у највећој мери користе јавни превоз.

Време потребно за путовање и раздаљина коју дневни мигрант може да свакодневно пређе до посла мењали су се током времена, под утицајем развоја саобраһаја и саобраһајне мреже. Генерално, просечно време путовања до посла је релативно константно, док се просечна удаљеност са које радник свакодневно путује до места рада и назад повећава, као резултат веће брзине коју развијају саобраһајна средства. Ови параметри дневних миграција разликују се на нивоу држава, али и у оквиру једне државе као резултат, поред саобраћајних услова, карактеристика мреже насеља, урбане структуре, и густине насељености одређеног подручја. Поређење на међународном нивоу показује да је најчешће време путовања дневних миграната до школе/посла 30 минута, често износи и сат времена, док веома мали број дневних миграната путује свакодневно два сата у једном смеру, те се може рећи да је ова временска удаљеност до школе/посла непожељна. Американци и Канађани живе најближе месту школовања/рада. Две трећине дневних миграната Северне Америке путује мање од 30 минута, док свега $8 \%$ путује више од једног сата до школе/посла. Већина Европљана такође живи у оквиру 30 минута потребних за путовање до школе или радног места, са свега $6 \%$ дневних миграната који проведу у путовању више од једног сата. У Италији нпр. већина радника путује до 15 минута, 25\% до 30 минута, а преко тога путује занемарљив број дневних миграната (Cristaldi F.,2005). Структура дневних миграната према времену које утроше на путовање до посла показује да радници у нашој земљи најчешће путују до посла између 16 и 30 минута, док више од 45 минута путује између $10 \%$ и $15 \%$ дневних миграната. Ученици и студенти утроше више времена на свакодневно путовање од радника (Стаменковић С., 1989; Стаменковић С. и др., 1995). Према анкети Савезног завода за статистику из 1957. године у седамдесет пет градова бивше Југославије просечна дневна удаљеност коју је прелазио дневни мигрант износила је између 20 и $30 \mathrm{~km}$ у једном смеру (CDI-IDN, 1971), па условно можемо рећи да у последњих тридесет година није дошло до већих промена у просторној дистанци дневне миграције.

У Европи највише времена у путовању до посла проведу радници у Великој Британији. Године 2001. у Енглеској је просечна просторна раздаљина дневне миграције у једном правцу износила $17 \%$ више него пре једне деценије. Британци свакодневно у путу до посла проведу просечно 45 минута, што је готово два пута више од времена путовања радника у Италији. Испитивање на принципу узорка у европским 
земљама показало је да радници у Енглеској највише проведу у путовању до посла (7 сати недељно или готово један додатни радни дан, односно радници проведу 47 дана годишње у свакодневном путовању до посла и назад). На супрот њима, радници дневни мигранти у Шведској утроше мање од четири сата недељно на путовање до посла. Просек времена потребног за свакодневно путовање до посла за раднике EU износи 38 минута (www.bbc.co.uk).

Табела 4. Просечно време путовања радника до посла у изабраним земљама 2004. год. (мин)

\begin{tabular}{|l|c|}
\hline Држава & Минуга \\
\hline Италија & 23 \\
\hline Шпанија & 33 \\
\hline Француска & 36 \\
\hline Ирска & 39 \\
\hline Холандија & 43 \\
\hline Немачка & 44 \\
\hline Велика Британија & 45 \\
\hline
\end{tabular}

www.bbc.co.uk

Разлике у простроној и временској дистанци дневне миграције изражене су и на регионалном нивоу у оквиру исте земље. У оквиру Велике Британије нпр. постоје велике међурегионалне разлике у времену потребном радницима дневним мигрантима за путовање до посла. У Шкотској радници у просеку путују 20 минута у једном правцу до посла, док у JI Енглеској радници у просеку путују до посла сат времена трошећи и до једне трећине плате на путовање (www.talentscotland.com). Према подацима Пописа становништва из 2000. године у САД, Американци у просеку путују до посла 26 минута у једном правцу. Време потребно за свакодневно путовање до посла разликује се међу државама. Најдуже путују до посла становници Њујорка (у просеку 43 минуте), док радници становници сеоских подручја имају најкраће време путовања до посла (мање од 15 минута), а на Аљасци чак 10 минута (Pollard K., 2002). У Јапану половина дневних миграната путује до школе/посла мање од 30 минута у једном правцу. Ученици/студенти (34\% путује свакодневно сат времена) путују дуже од радника дневних миграната ( $21 \%$ путује свакодневно сат времена). Дужина путовања зависи и од врсте превозног средства. Половина дневних миграната који иду возом путује више од једног сата. Око $70 \%$ дневних миграната који путују аутобусом путује мање од једног сата у једном правцу до школе/посла. За $60 \%$ оних који се возе аутом путовање до школе/посла не траје дуже од 30 минута. Поред врсте превоза место становања показује се као значајан фактор за време путовања до посла и у Јапану. Дуже од два сата путује $7 \%$ радника из сеоских насеља и свега $2 \%$ радника који станују у граду (www. japan-guide.com).

Бројни су фактори који утичу на просторну и временску дистанцу дневне миграције. Демографске и социоекономске карактеристике дневног мигранта и структура и карактеристике домаћинства дневног мигранта један су од фактора утицаја на дистанцу дневне миграције. Према истраживањима високообразовани радници имају веће дистанце дневне миграције, док жене нпр. путују свакодневно на краћим удаљеностима (Rietveld P., Van Woudenberg, 2003; White M.,1988). На време и раздаљину свакодневног путовања до посла утиче и број радника у домаћинству. Уколико у домаћинству постоје два радника (тзв. two earner household) и ако су оба радника у домаһинству дневни мигранти већа је вероватноћа да један радник изабере путању дневне миграције која изгледа беспотребна. Овај радник не иде директно до посла и назад, већ стаје на више места обављајући успут текуће послове (вожња деце до школе или вртића, набавка и слично) што утиче на већу дистанцу дневне миграције. Због тога радници не путују свакодневно само главним путевима као што би било 
идеално за минимизирање просечне путање дневне миграције (Hamilton B.W.,A. Roell, 1982).

За дистанцу дневне миграције велики значај има доступност и карактер радних места. Краће дистанце дневних миграција могу се очекивати у подручјима где постоје разноврсни послови у односу на радну снагу. Стога су дистанце дневне миграције краће у урбанизованијим и више индустријализованим центрима. Постоји неколико индикација везе између варијација у дистанци дневне миграције и локације индустријских постројења у односу на стамбена насеља. Популациона величина града други је фактор често разматран као могући узрок варијација у путањама дневних миграција. У неким државама откривена је директна веза између бројности градске популације и просечне дистанце дневне миграције. Просечна дистанца дневне миграције најкраћа је у градовима од 10-25.000 становника и повећава се у градовима са већом популацијом (Thompson J.Н.,1956).

Обим и правци дневних миграција ограничени су временском, просторном, али и економском (трошкови превоза) раздаљином путовања. Веома често се поред временске и просторне разматра и економска дистанца дневне миграције, која подразумева економске трошкове засноване на транспортним трошковима дневне миграције. У контексту ефикасног модела зарада има случајева нпр. постављања границе удаљености дневне миграције од стране послодавца за пријем радника, ради веће ефикасности на послу (Shapiro, Stiglitz,1974, према Rouwendal J., P. Nijkamp,2004). Трошкови дневне миграције пропорционални су раздаљини између места рада и места становања и радници са различитим примањима могу себи да приуште различиту висину ових трошкова, што утиче на избор врсте превозног средства и дужине путовања. Предмет проучавања истраживача дневних миграција често је и вредност времена утрошеног на свакодневно путовање до посла, VOT (value of time), како то називају економисти. Генерално, вредност времена једнака је трошковима времена проведеног у путовању, што је најчешће везано за висину прихода радника. Емпиријска истраживања потврдила су везу између ове две варијабле. Према истраживањима различитих аутора вредност времена утрошеног на путовање креће се до $20 \%$ од износа примања дневног мигранта (Rouwendal J., P. Nijkamp,2004).

Нема општег мишљења о томе шта је граница преко које се може сматрати да је раздаљина коју дневни мигрант свакодневно прелази до посла дуга. Бургес у свом зоналном моделу града, средином 20-тих година прошлог века дефинише зону дневних миграција као зону која се простире иза зоне изградње града и са спољном границом од око сат времена путовања од свог центра (Thomas D.,1990). Пар сматра да је горња граница за свакодневно путовање дневног митранта 28 km (Parr J.B., 1987). У схватању дугог путовања време утрошено на путовање је можда важније од дистанце. Мишљења о зони временске толеранције дневне миграције су различита. За једне је то 30 до 45 минута (Van der Laan L.,1998), док Фригановић нпр. сматра да би се дневно путовање на посао преко један сат у једном смеру ваљало сматрати нерационалним. Издваја три категорије дневних миграција на основу утрошеног времена на путовање у једном смеру: кратке (мање од 30 минута), средње (30-60 мин.) и дуге (више од 60 мин.) истичући да је гранично време путовања дневних миграната у оба смера врло значајно за оцену степена миграционе стабилности неког подручја. Дуге дневне миграције су углавном карактеристика дневних миграната из граничних подручја гравитационих зона атрактивних центара чије је залеђе карактеристично по дисперзној и реткој насељености те по недовољној мрежи саобраћајница (Friganović M., 1970). Бројна истраживања путања дневних миграната довела су до запажања да нема великих варијација у просечном времену потребном за путовање дневног миграната, те да су вредности временске дистанце до посла релативно константне кроз време. Постоје 
различита објашњења овог феномена. Гетис (1969) је постулирао постојање критичних изохрона или максимума прихватљиве дистанце дневне миграције. Гордон, Ричардсон и Јун (1991) постулирали су хипотезе колокације према којима домаћинства редовно прилагођавају место становања и место рада како би избегли прекомерна свакодневна путовања. Левинсон и Кумар (1994) проширују ову претходну хипотезу рационалног локатора на послодавце који треба да се релоцирају како би остали довољно близу својој потенцијалној радној снази. Отпор према великим дистанцама за дневне миграције неки аутори сматрају као главну силу која формира урбану структуру (Rouwendal J., P.Nijkamp,2004).

Реитсма и Вергосен посвећују посебну пажњу импликацијама које дистанце дневне миграције и миграције имају за одлуке које се тичу радне миграције и промене места становања. Резултати модела показују да дуге дневне миграције повећавају вероватноћу за дефинитивну миграцију. Толеранција дневне миграције се дефинише као максимум времена које испитаник спреман да утроши на дневну миграцију. Потенцијално време дневне миграције је оно које би испитаник морао да утроши да се није преселио. Испитивање миграната према мотивима је показало да је код радника који су се преселили због посла потенцијално време прелазило време толеранције. Фактори који утичу на вероватноћу прелажења прага толеранције дневне миграције су:

- потенцијално време дневне миграције,

- начин превоза: спори (бицикло, пешачење), брзи (аутомобил, воз, аутобус),

- флексибилност радних сати у периоду пре миграције (Reitsma R., F.Vergoossen, 1987).

За разлику од временске димензије дневне миграције, просторну димензију дневне миграције последњих деценија одликује пораст просечне дистанце дневне миграције у многим земљама. На примеру насеља у Словенији наводи нпр. се да је временски губитак 1970. године од $14 \mathrm{~km}$ исти као $4 \mathrm{~km}$ пред Први светски рат (Klemenčić V., 1962). Бројни фактори су утицали на све већу флексибилност места рада у односу на место становања. У Америци резултати Пописа становништва из 2000. године показују смањење удела радника са малом раздаљином до посла и назад, и пораст удела дневних миграција са дугим дистанцама. Значајан се показао и фактор удела домаћинстава са два радника, као и присуство деце. Жене често краће путују али и присуство деце може узроковати дуже путовање до посла како би се домаћинства лоцирала у близини боље школе. Резултати Пописа показују да је за разлику од осамдесетих година прошлог века, у другој декади деведесетих била веома важна улога прихода за путање дневних миграција. У овом периоду дошло је до пораста прихода многих домаһинстава. Домаһинства са већим приходима су прихватила дужа путовања до посла у замену за веће куће на удаљенијим неурбаним локацијама и мање загађеним подручјима (Gordon P., B. Lee, H.W.Richardson, 2004). У Великој Британији се дистанца дневне миграције повеһала са мање од $4 \mathrm{~km} \mathrm{1890.} \mathrm{године} \mathrm{на} 13 \mathrm{~km}$ до осамдесетих година прошлог века. То је последица чињенице да је пешачење као најчешћи вид превоза замењено аутобусом, а затим колима. Као разлози за повећање дужине путања дневних миграција наводе се следећи фактори:

- нестанак традиционалних индустријских послова (чије је особље често било локално),

- континуирана дисперзија популације ван урбаних центара (за земље Северне Америке и Западне и Северне Европе),

- промене у структури популације у смислу пораста професионалних радника које карактеришу путање дневних миграција дуже од просека, 
- настављен пораст употребе аутомобила (Green A.E., T. Hogarth, R.E.Shackelton, 1999).

Као посебан облик дневних миграција у западноевропским земљама и Северној Америци у новије време се појављују се тзв. дуге дневне миграције, односно дневне миграције на великим раздаљинама. Деурбанизација у Енглеској је довела до драстичног пораста у броју дневних миграната на веће дистанце у последњој деценији. У Великој Британији 1981. године $10,8 \%$ дневних миграната путовало је до посла више од $30 \mathrm{~km}$, док је 1991. године $13,6 \%$ радника путовало на овој просторној удаљености. Према истраживањима Алборг Универзитета у Немачкој, између пописа становништва 1991. и 2001. године у Великој Британији број дневних миграната који свакодневно путују више од $50 \mathrm{~km}$ порастао је за $30 \%$ (Edwards C.,2005). Дневне миграције на дугим релацијама одлика су и становништва великих азијских и америчких градова. Истраживања путања дневних миграната на националном нивоу врше се у САД константно већ двадесет година. Испитивања на принципу узорка 2004. године у САД показала су да је један од 200 дневних миграната тзв. stretch дневни мигрант, односно да 3,3 милиона Американаца путује најмање 50 миља, или $80 \mathrm{~km}$, у једном смеру до посла. Дневни мигранти на овако великим раздаљинама претежно су мушкарци, пет од шест су радници у производњи, грађевини, стручњаци и менаџери. Три од пет су из домаһинстава са приходима најмање 50.000 долара а два од пет су из сеоских насеља (US Department of Transportation, 2005).

Временска и просторна раздаљина дневне миграције функција је више фактора. У зависности од утицаја ових фактора понекад је за исте просторне удаљености потребно више или мање времена за путовање. Удаљеност између места становања и места рада мања је у случају веће доступности и развијености саобраһајне мреже, што утиче на ширење функционалног подручја центара, пружајући дневним мигрантима већу флексибилност у погледу радног места без великог утрошка времена у путу. Начин превоза односно избор превозног средства је такође фактор који има битан утицај на време потребно за путовање до посла. С обзиром да свако превозно средство има своју брзину и особености, Реитсма начин превоза дели на спори (бицикло, пешачење) и брзи (аутомобил, воз, аутобус) (Reitsma R., F.Vergoossen, 1987). За путовање до посла сопственом превозом (аутом) најчешће треба мање времена него за путовање јавним саобраћајем, с обзиром да се одређено време утроши на одлазак до најближе станице јавног саобраһаја, као и за чекање превоза. Избор врсте превозног средства зависи и од доступних могућности и развијености саобраһајне мреже, које су сразмерне степену урбанизованости и популационој величини насеља. У великим светским метрополама, као што је на пример Њујорк, са добро решеним системом јавног превоза, учешће јавног саобраћаја као врсте превозног средства дневних миграната прелази $50 \%$ (Schaller Consulting, 2002).

Поређење врсте превоза дневних митраната на међународном нивоу указује на разлике у коришћењу система јавног саобраћаја за свакодневно путовање до посла. Ове разлике резултат су природно-географских особености земаља, али и степена достигнутог друштвено-економског развоја и специфичности саобраћајне мреже. Велико учешће јавног саобраћаја у структури дневних миграната ученика/студената, али и радника према врсти превоза изражено је у Источној Азији, док у другим земљама света дневни мигранти мање користе јавни саобраћај. Возом се до посла превози свега $3 \%$ дневних миграната Северне Америке, 13\% Европљана и 24\% становника Источне Азије (у Јапану сваки други дневни мигрант превози се возом до посла). Аутобусом се вози 13\% дневних миграната у Северној Америци, 11\% Европљана и $39 \%$ дневних миграната у Источној Азији (у Јапану 9\%). У Северној 
Америци $71 \%$ радника дневних миграната и сваки други студент путују аутом. У Европи је овај однос $58 \%$ на према $10 \%$, а у Источној Азији $25 \%$ на према $15 \%$. У Европи $8 \%$ ученика/студената, и свега $2 \%$ радника користи бицикло за свакодневни превоз, док у Северној Америци и Источној Азији мање од $2 \%$ дневних миграната укупно, користи бицикло за свакодневно путовање. Најчешћи вид свакодневног превоза до посла у Јапану је воз. Већина студената дневних миграната (53\%) и радника дневних миграната (48\%) путује у школу/на посао возом или метроом. Други по значају вид превоза јесте аутобус, што утиче на учешће јавног саобраћаја у превозу дневних миграната са $61 \%$ за ученике - студенте и $57 \%$ за раднике. Сопственим аутомобилом превози се свакодневно $24 \%$ радника дневних миграната и $6 \%$ студената. Ауто се користи чешће као вид превоза радника дневних миграната који живе у сеоским насељима ( $64 \%$ радника који станују у сеоским насељима на према $14 \%$ градских дневних миграната) (www.japan-guide.com). У Шкотској је употреба јавног превоза од стране дневних миграната такође јако изражена. Од укупног броја дневних миграната у Глазгову $40 \%$ користи јавни саобраһај (www.talentscotland.com).

У већини земаља приметан је тренд пораста употребе сопственог возила, као врсте превоза дневних миграната радника. Према подацима Пописа становништва у Америци из 2000. године, нешто мање од 5\% дневних миграната путује до посла јавним саобраћајем, док се готово $76 \%$ Американаца вози сопственим аутом до посла и назад. У поређењу са подацима из 1990. године број дневних миграната који користе јавни саобраһај се смањује, док је број радника који се сами возе до посла порастао за $3 \%$. У више од пола америчких држава, мање од $2 \%$ дневних миграната користи јавни саобраһај. Употреба јавног саобраһаја је доминантна само у државама у којима се налазе велика метрополитанска подручја (Pollard K., 2002). У Енглеској седам од десет дневних миграната, који станују изван Лондона путују сопственим аутом до посла. Јавним саобраћајем превози се свега $11 \%$ (железницом само $5 \%$ ) дневних миграната. Чак и уколико би се њихово време путовања удвостручило због саобраћајних гужви, готово половина возача изјавила је да не би променила вид превоза већ би издвојили више времена за путовање. Само 7\% прешло би на јавни саобраћај као врсту превозног средства. Када је реч о разлозима за избор сопственог аутомобила као врсте превозног средства дневних миграната, од укупног броја испитаника $55 \%$ се изјаснило да користи ауто као облик превоза због тога што је бржи од других опција, $36 \%$ због тога што користи ауто на послу и $28 \%$ због непоузданости јавног саобраћаја (bbc.co.uk). Д. Лајблинг и Е. Кинг из РАЦ Фондације испитивали су могуће варијације у избору врсте превоза дневних миграната, нарочито возача аутомобила. Приметна је велика зависност од употребе сопственог аутомобила за свакодневно путовање до посла. Просечан возач аутомобила био би спреман да путује дуже 15 до 20 минута у односу на садашње време које му је потребно за путовање, са прихватљивих до 50 минута проведених у путовању. Уколико би се удвостручило време потребно за путовање аутомобилом, $46 \%$ дневних миграната би једноставно одвојило више времена за путовање, $23 \%$ би користило друге правце, док би свега $7 \%$ прешло на јавни саобраћај као вид превоза. Уколико не би могли да користе ауто као вид превоза $8 \%$ дневних миграната би чак променило посао (The Rac Foundation, 2003). У Италији подаци показују већу употребу аутомобила од стране дневних миграната од 1981 године (Cristaldi F.,2005).

Напред наведени подаци указују на велики утицај врсте превоза и типа и величине насеља на време потребно за путовање дневног миграната. Бројнији подаци о врсти превоза дневних миграната и у нашој земљи били би вишеструко корисни. У нашој земљи највећи број дневних миграната користи јавни превоз, а доминантно средство превоза је аутобус (Стаменковиһ С., 1989; Стаменковић С. и др., 1995; Бјељац Ж., 1992; Петровић Г., 2001). Такође има случајева да дневни мигранти комбинују 
различита превозна средства. Избор јавног превоза, као најчешһег начина путовања до посла када је реч о дневним мигрантима у нашој земљи, није последица поузданости, брзине и удобности јавног превоза као што је то случај у неким западноевропским земљама, већ претежно високих трошкова превоза сопственим аутомобилом, које већина дневних миграната не може да поднесе финансијски. То не значи да са промењеним условима рада и порастом животног стандарда дневних миграната не можемо очекивати промене и у избору врсте превозног средства.

\section{8. Селективност дневних миграција}

С обзиром да је миграција селективан процес дневни мигранти не представљају у потпуности популацију активног становништва насеља рада. Бројна истраживања показују да просторна раздаљина између места становања и места рада, време проведено у путу, врста превоза и трошкови путовања варирају у зависности од демографских и социоекономских карактеристика дневних миграната (Лукић В.,2007). Демографске карактеристике дневних миграната важне су и због значаја животног циклуса у миграцији. Личне и карактеристике домаћинстава за које је потврђено да утичу на просторну и временску дистанцу путовања дневног мигранта укључују пол, старост, образовање, занимање, приходе, доступност аута и величину и састав домаћинства (Levinson D., 1998). Свака промена у структури укупног становништва, преко промена у структури популације дневних миграната одражава се на трансформације обима, структуре и просторне усмерености дневних миграција.

Проучавање разлика у путањама дневних миграната према полу започело је почетком 80-их година 20. века. Већина истраживања показује да жене мање учествују у дневним миграцијама и да путују на мањим раздаљинама од мушкараца (временски и просторно краће) (Maden, 1981; White M.,1986). У дневним миграцијама активног становништва у Србији такође више учествују мушкарци (65\%) од жена $(35 \%)$ (P3С,2004). И у профилу запосленог дневног мигранта у већини земаља OECD-а разлике према полу су јасно изражене. Само у Француској, жене више учествују од мушкараца у дневној миграцији (OECD,2005). Ближе кући удео жена и радника са скраћеним радним временом расте (Van der Laan L.,1998). Поред тога што мање учествују у дневној миграцији од мушкараца, жене такође свакодневно путују на просторно и временски мањим раздаљинама у односу на мушкарце. Новија литература показује да се разлике у времену путовања до посла између мушкараца и жена смањују, мада су и даље изражене (Vandersmissen M.H., P.Villeneuve, M.Thériault,2003; Cristaldi F.,2005; Camstra R., 1996)

Различите просечне дужине путовања од куће до посла у зависности од пола дневног мигранта доводе се у везу како са економским факторима (висина прихода, занимање, карактеристике регионалних и локалних тржишта рада, врста превоза), тако и са факторима који су значајни због фазе животног циклуса (брачни статус, родитељство, старост и број деце). И образовање, као фактор који утиче на висину прихода и економски статус жене али и аспирације жена везане за напредовање у каријери, утиче на путање дневних миграција жена (Лукић В.,2007). Постоје послови и делатности у којима преовладавају жене ${ }^{8}$. Њихов географски размештај утиче на доступност запослењу за жене, што се одражава на токове и обим дневних миграција. У рударским подручјима нпр. има више радника мушкараца, док у подручјима са развијеном текстилном индустријом раде претежно жене. Хансон и Прат сматрају да су неједнакости у путањама дневних миграција више одређене типом послова на којима је

\footnotetext{
${ }^{8}$ Према Турнеру и Неимиеру женска занимања су она где 70\% и више чине жене (Turner, Niemeier,1997).
} 
могуће запослење жена и мушкараца него факторима везаним за домаћинство, што утиче на избор облика просторне покретљивости, с обзиром да је тип послова везан за степен образовања и висину прихода. Аутори истичу да су главни фактори који утичу на краће време путовања жена до посла нижи приходи, концентрација у занимањима карактеристичним за жене и већа овисност о јавном превозу, с обзиром да путовање јавним превозом захтева више времена, због времена утрошеног на одлазак до најближе станице превоза, као и за чекање превоза (Hanson S., G.Pratt,1995, према Cristaldi F.,2005). И други фактори, осим економских, делују на дневну миграцију активних жена. Један од њих је фаза животног циклуса жене (промене у животним потребама током времена). Биолошке (старост и пол) и социолошке карактеристике дневних миграната, као што је брачно стање, важне су због значаја животног циклуса у миграционом процесу - оне су индикатори фазе животног циклуса. Од фазе животног циклуса жене зависи и одговорност - обавезе жене у домаћинству. Бројна истраживања упуһују на хипотезу одговорности у домаћинстєу као разлог за различите путање активних дневних миграната према полу (Johnston-Anumonwo I.,1992; Turner T., D.Niemeier,1997). Као показатељ одговорности у домаћинству најчешће се користи брачно стање жена, присуство деце, године старости деце и број одраслих чланова домаћинства. Акценат је на домаћинствима са два радника (тзв. two earner households) због претпоставке да је за два радника у домаћинству теже да обоје нађу запослење у локалној средини. Према Камстри жене се генерално више селе (мењају и место становања и посао), док мушкарци више мењају само место становања. На краће путање жена дневних миграната у односу на мушкарце утичу три фактора:

- жене често подносе већи део обавеза у домаһинству и самим тим морају да више цене време,

- жене ређе имају приступ породичним колима,

- у градовима има више жена (Camstra R.,1996).

Путања дневне миграције жена често је креирана тако да повезују различите тачке у простору где жена има обавезу да застане. Краће свакодневно путовање жена до посла последица је делом и чињенице да су запослене породичне жене везане за локалну средину и због упуһености на неке јавне службе као што су предшколске или школске установе, што ограничава њихову просторну покретљивост (Лукић В.,2007). Активности које нису везане за посао веома су важне за разумевање разлика у путањама до посла према полу. Због тога постоји потреба анализирања нелинеарних кретања жена, односно оних која не полазе из појединачне тачке као што је место становања, већ из више тачака чинећи ланац кретања/од куће до посла, затим од дечје школе/вртића онда даље до супермаркета и на крају опет до куће (Cristaldi F.,2005).

С обзиром да дневна миграција обухвата део активног становништва, школске деце и омладине, старосна структура дневних миграната има знатно мањи распон од старосне структуре укупног становништва. Старост може да утиче на два начина на дневну миграцију (преференце радника варирају у зависности од животног циклуса, и зараде радника расту са искуством - које се повећава са годинама што смањује ограничења кућног буџета у погледу места становања) (Romani J., J.Surin, M. Artis, 2003). Честа су проучавања везе између година старости радника и вероватноће за дневну миграцију, као и везе између година старости радника и просторне и временске дистанце дневне миграције. Веза између старости и вероватноће за дневну миграцију, као и раздаљине дневне миграције често је нелинеарна, где млађи и старији радници путују са мањом вероватноћом и краће од радника средњих година. Радници млађи од 25 или 35 година слабо учествују у дневним миграцијама и путују на краће раздаљине у односу на раднике старости између 36 и 50 година. Највећу вероватноћу за учешће у 
дневној миграцији имају радници у старосним групама $35-40$ и 45-50. После 50 година опада вероватноһа за учешће у дневној миграцији (Lee B.S., J.Mc Donald,2003; Romani J., J.Surin, M. Artis, 2003). Највеће учешће младих радника (старости од 15 до 24 године) у дневним миграцијама има Немачка (OECD,2005). Структура дневних миграната према годинама старости није доступна из објављених резултата Пописа становништва у Србији. Варијабилност овог обележја дневних миграната може се пратити само на основу проучавања дневних миграција путем анкете на одређеним подручјима или захтева за посебну обраду података пописа становништва.

Дневни мигранти, осим према полу и старости, селективни су и према делатности коју обављају. Бројна литература упућује да је индустрија сектор делатности са највећим обимом дневних митрација (нарочито прерађивачка индустрија која захтева удаљеније локације), прате је енергетика, грађевина и сервисне услуге. Највећа вероватноћа за учешће у дневној миграцији јесте код запослених у секторима који подразумевају велике фабрике као што је хемијска индустрија или метална и машинска индустрија, јер ове индустрије тешко могу подмирити потребе за радницима на локалним тржиштима рада (Eliasson K., U.Lindgren, O.Westerlund, 2003). У Србији су запослени у секундарним делатностима највише учествовали у дневним миграцијама како 1961. године, тако и 2002. године (С3С;1967;Р3С, 2004). Концентрација или деконцентрација одређених делатности, у складу са специфичним локационим захтевима, битно утиче на обим, правце и структуру токова дневних миграција. Јавне административне службе, банкарство и финансије налазе се најчешће у самом центру града, па из тога произилази мањи обим дневних миграција радника запослених у сервисним делатностима. Дневни мигранти запослени у сервисном сектору генерално путују краће од осталих, што има везе са размештајем овог сектора делатности (Lee B.S., J.Mc Donald,2003). У Шпанији нпр. регион Барселоне привлачи велики број сервисних радника, док у дивергентним токовима дневних миграната преовладавају индустријски радници (Artis M., J.Romani, J.Surinach, 2000). Првобитне дневне миграције активног становништва, у свету и код нас, одликовала је двострука радна ангажованост дневних миграната, у смислу рада на послу и рада на пољопривредном имању. Бројчаним смањивањем и старењем пољопривредног становништва смањио се и извор радне снаге за непољопривредне делатности. Појава делимичне ангажованости у пољопривреди је данас знатно мање заступљена. Најмање дневних миграната запослено је у пољопривреди, рибарству и шумарству.

Образовање је важно обележје становништва у миграционим проучавањима. Опште је прихваћено становиште да је образованије становништво више просторно покретљиво и да путује на веће удаљености. Досадашња сазнања о разликама у обиму и правцима дневних миграција према образовању указују да је већи степен образовања везан са веһом вероватноћом појаве и већим раздаљинама и када је реч о дневним миграцијама становништва. Већа улагања у хумани капитал (образовање и радно искуство) доводе се често у везу са већом просторном и временском раздаљином дневне миграције како за мушкарце тако и за жене (Turner T., D.Niemeier,1997.; Madden J.F.,1981). То потврђује сазнања теорије о миграцијама да степен позитивне селекције мигранта расте са тежином додатних препрека (Lee E.S.,1966). Различит обим токова дневних миграција становништва према образовању резултат је неусклађености локалних тржишта рада и појединачних каријера. Образованији радници често не могу наћи одговарајуће запослење у свом насељь, или имају аспирације за стручним усавршавањем које не могу реализовати у насељу становања. "Квалификованији радници траже посао више просторно екстензивно што резултира у већим путањама свакодневног путовања до посла" (Simpson W.,1987). У свом истраживању на примеру Ворчестера, Хансон и Прат доказују да је за мањи део популације за који одлуке о 
запослењу претходе а не следе одлуке о месту становања реч о високообразованим мушкарцима и женама стручњацима (Hanson S., G.Pratt, 1988). Селективност дневних миграната према образвовању зависи и од структуре привреде подручја. Нпр. у урбаним системима Рима и Трста у Италији запослени дневни мигранти који су високообразовани превазилазе национални просек. Кристалди на примеру Италије закључује да је образовање статистички најзначајнија варијабла која има утицаја на путање дневних миграција жена. Жене са лошијим образовним квалификацијама путују на краће дистанце и обрнуто у оквиру већег функционалног подручја (Cristaldi F.,2005).

Са степеном образовања дневних миграната у вези су и варијације у просторној оријентацији путања дневних миграција. У структури дневних миграната западноевропских земаља према образовању, преовладавају високообразовани у Великој Британији и Немачкој, док у Француској и Италији веһина дневних миграната има основно образовање, а у Аустрији средње образовање (OECD,2005). Оваква структура дневних миграната према образовању делимично одражава различите форме урбаног развоја - док богатије групе становништва у неким земљама напуштају градске центре, у другим земљама припадници средње економске класе и најсиромашнији више живе у предграђима и путују до центра на посао. Има случајева и да истраживачи користе степен образовања за процену зараде дневног мигранта, имајући у виду да је висина прихода чест социоекономски индикатор варијација временске и просторне димензије дневне миграције и чињеницу да постоји позитивна веза између степена раздвојености места рада и места становања и социоекономског нивоа радника (Artis M., J.Romani, J.Surinach, 2000; Schwanen T., F.M.Dieleman, M.Dijst, 2004;Yu E.Y.,1972). Генерално је истина да што радници више зарађује више су спремни да времена и новца утроше на дневну миграцију (De Vise P.,1976). Већина дневних миграната у CAД и Енглеској који станују ван центра су радници са већим примањима који су добровољно одабрали да свакодневно путују дуже до посла да би живели у еколошки мање нарушеној средини. У нашој земљи процес деурбанизације још није узео маха делимично захваљујући нижем економском стандарду, али и још увек неразвијеној свести о предностима живота у приградским насељима у односу на градске центре.

Дневни мигранти су селективни и када је реч о карактеристикама домаћинства. "Одлука о односу места рада и места становања функционише различито за различите структуре домаћинства" (Hanson S., G.Pratt,1988). У складу са сазнањима Минцера (Mincer J.,1978), да ефекти породичних веза утичу на смањење просторне покретљивости становништва, претпоставља се да самци имају већу вероватноћу за учешћем у дневним миграцијама, нарочито на дужим просторним и временским релацијама, јер су самачка домаһинства мање ограничена породичним факторима при избору места становања.

С обзиром на старосну границу која одређује радну снагу већина дневних миграната радника је у браку. Истраживања обављена у нашој земљи показују да је око $80 \%$ дневних миграната у браку (Петровић Г.,2001;Стаменковић С. и др.,1995.). У случају брачних парова где је обоје супружника запослено, теже је за обоје да нађу запослење у месту становања, те да се функција рада за обоје супружника обавља у насељу становања. Чињеница да су у домаһинству два радника који свакодневно путују може повећати трошкове дневне миграција и тиме утицати на пресељење домаћинства ближе њиховим местима рада тако смањујући време дневне миграције (Simpson W., 1987). Има случајева да када дистанца између места становања и места рада прелази дневну раздаљину то може резултирати двојном локацијом домаћинства, где партнери живе раздвојени током радне недеље (Camstra R.,1996).

Имајући у виду напред наведено, у последњих двадесет година су веома честа испитивања домаћинстава са два запослена и понашања припадника овог типа 
домаћинства у миграционом процесу. Ова истраживања нарочито су значајна имајући у виду све већу радну ангажованост жена, која им отежава усклађивање пословних и породичних обавеза. Најчешће се анализира учешће и дистанца дневне миграције мушкараца и жена у домаћинствима са једним и два радника, затим у зависности од присуства деце, броја деце и година старости деце. Има случајева и испитивања утицаја присуства још неког лица у домаћинству (треће генерације - баке и деке) на учешће жена са децом у дневној миграцији, и просторну и временску димензију дневне миграције жена. Иако се истраживачи генерално слажу да жене свакодневно путују краһе до посла од мушкарца, те да разлике у полу које показују дневни мигранти приликом понашања у дневним миграцијама зависе од структуре домаћинства, различити су резултати истраживања о утицају деце на дистанцу дневне миграције жена. Просторна и временска дистанца дневне миграције код већине жена се смањује са присуством деце у породици и повећањем броја деце, мада има случајева да се за пресудни фактор утицаја на путање дневних миграција жена сматра брачно стање а не родитељство (Лукиһ В.,2007).

У Великој Британији Грин је извршио истраживања које се односе на то где домаћинства са два радника бирају да живе и раде, када и где бирају да мигрирају односно не мигрирају и како и зашто доносе ове одлуке. Утврдио је у ком делу земље је највећа концентрација оваквих домаћинстава, затим да је претежно реч о домаћинствима која станују у приградским подручјима са добрим саобраћајним везама, те да доминантан утицај у одлукама има партнер чија су примања већа, каријера сигурнија или чији је посао више локационо ограничен. Резултати овог истраживања показују да је место становања тако одабрано да максимизира потенцијал дневне миграције и минимизира потребу за будућом дефинитивном миграцијом (Green A.E., T.Hogarth, R.E.Shackelton,1999). Традиционална улога жене у домаһинству и доминантност каријере мушкарца сматрају се за разлоге краһег путовања жена дневних миграната и чињенице да неки резултати указују да и мушкарци и жене чешће очекују пресељење због промене посла мушкарца него жене. Поједина истраживања показују да је са локације места становања садашњи посао одабрало $63 \%$ мушкараца и $93 \%$ жена (Hanson S., G. Pratt, 1991). Хансон и Прат такође сугеришу да постоји одлучивање у домаћинству о свакодневном путовању до посла, при чему партнер са већом зарадом има доминантну позицију (Hanson S., G.Pratt, 1995 према Cristaldi F.,2005).

Каин је први формулисао да жене прилагођавају своје место становања локацији места рада мушкарца док жена прилагођава своје место рада локацији куће (Каin J.,1962). Сермонс и Копелман потврђују да мушкарци генерално путују дуже од жена и ова разлика је већа у домаћинствима са децом (Sermons M.W., F.S.Koppelman,2001). Поређење дистанци дневних миграција за мушкарце и жене у домаћинствима где ради једно или двоје супружника у Балтимору потврђује хипотезу да је већи диспаритет где ради двоје укуһана, закључујући да је брак важнији фактор за варијабилност дневне миграције према полу него присуство деце (Johnston-Anumonwo I.,1992). "Присуство деце је главни фактор за краће дистанце дневне миграције жена у поређењу са мушкарцима. Присуство деце млађе од 16 година у домаћинству значајно смањује време дневне миграције жене и ово се време смањује са бројем деце" (Lee B.S., J. Mc Donald,2003). И у Холандији присуство деце је најзначајнији фактор за објашњење диференцијација у времену дневне миграције између мушкараца и жена. Жене у домаћинствима са децом путују не само мање од мушкараца већ и мање од других жена које су у браку али немају децу. Како се околности мењају и како искрсавају нове могућности и ограничења домаћинство са два радника може усвојити нову стратегију (Schwanen T., Dieleman T.M., Dijst M., 2004). Деца различитог узраста имају и различите потребе и обавезе што се такође може одразити на правце дневних миграција 
мушкараца-очева и жена -мајки. Уколико родитељи свакако возе дете у школу у друго насеље могућност рада у датом насељу неће им бити страна. У том случају нпр. просторно покретљивији би били родитељи са децом школског узраста.

Различита су и запажања о утицају присуства треће генерације или другог одраслог члана домаћинства који није запослен на дневну миграцију жена. Присуство треће - помажуће генерације у домаћинству може да омогући жени да свакодневно путује дуже и борави више ван куће. Хансон и Прат су утврдили да присуство одрасле особе која не ради у домаћинству нема утицаја на дистанцу дневне миграције жене (Hanson S., G.Pratt, 1995, према Cristaldi F., 2005). Има и другачијих сазнања. "Присуство особа старијих од 59 година у домаћинству има позитиван утицај на дневну миграцију жена, који је мањи уколико муж не ради, пошто он преузима део обавеза у домаћинству" (Lee B.S., J.Mc Donald ,2003).

Једно од обележја становништва које није у нашем даљем раду детаљније разматрано, али привлачи велику пажњу јавности у бројним земљама, јесте варијабилност обима и праваца дневних миграција у зависности од расне или етничке припадности. У Великој Британији и Америци бројна су истраживања ове проблематике. Полази се од претпоставке да су етничке групе најчешһе просторно концентрисане, што ограничава њихове могућности за запослење. Ова проучавања често се базирају на Каиновој хипотези просторне неподударности "spatial mismach hypotesis", према којој непоклапање места становања и места рада доводи до смањивања могућности за запошљавање сиромашних или мањинских расних или етничких група (Kain J., 1968). Процена токова дневних миграција мањинских етничких група у Енглеској и Велсу 1991. године нпр. показује да мањинске групе двоструко више овисе о јавном превозу и прелазе свакодневно веће раздаљине на путу кућа-посао (Owen D., A.E.Green,2000).

\section{9. Природа везе између дневне и дефинитивне миграције}

Различити облици просторне покретљивости становништва нису потпуно независни у простору и времену већ чине јединствену целину, те их тако треба и посматрати са циљем разумевања везе између различитих типова миграција у зависности од демографских и социоекономских структура миграната, мреже насеља, друштвено-економских услова и саобраћајних веза простора полазишта и одредишта. Могућности трансформације једног типа миграција у други тип су бројне. Промена услова одвијања миграција или правног статуса мигранта нпр. може бити заслужна за преображај једног облика миграција у други. Облици миграција под утицајем су друштвено-економских промена у насељима, промена у саобраћајној мрежи, социоекономској структури миграната (стицање већег образовања нпр.) или у структури породичног домаһинства, као и животном стилу. До преласка једног типа миграција у други могу довести и нове информације или деловање социјалних мрежа. Стога се не може се разматрати миграциони процес а да се не узме у обзир његова динамичност. "Промене у нивоу дефинитивне миграције могу одражавати ништа више него веће или мање ослањање на друге форме миграција како се мењају услови у месту полазишта и одредишта и унапреl)ују саобраһајни и комуникациони системи" (Goldstein S., 1987).

Разматрање везе између дефинитивне и дневне миграције значајно је како из теоретских тако и из практичних разлога. Са демографског аспекта веза између дневне миграције и дефинитивне миграције је веома битна, иако дневна миграција не утиче директно на промене у обиму и структури становништва, због потенцијалног прерастања дневне у дефинитивну миграцију. "Степен дневне мобилности 
становништва може представљати наговештај о даљим дефинитивним пресељавањима становништва с обзиром да су подручја са интензивнијим контактима са развијенијим центрима подложнија емиграционим тенденцијама" (Žuljić S., 1970). Промене у облицима просторне покретљивости становништва одражавају се на демографски и друштвено-економски развоја како простора полазишта, тако и простора одредишта, изазивајући промене у броју и структури становништва као и промене на тржиштима рада и некретнина.

Розман прави разлику између делимичног и потпуног пресељења у зависности од тога да ли се недељни циклус кретања мигранта у потпуности или делимично мења. Истиче да су многе миграције делимичног пресељења део процеса прилагођавања до чије је потребе дошло услед наглог тоталног миграционог кретања (Roseman C., 1971). Веза између дневне и дефинитивне миграције предмет је проучавања и домаћих аутора, који такође запажају чињеницу да "дневна миграција често може бити претходница коначне миграције - корак ка прилагођавању на ново место". Етнографска проучавања шездесетих година 20. века, на примеру Младеновца и Колубарског басена, као средишта развоја индустрије и рударства, обухватила су једним делом и проблематику дневних миграција, потврђујући да је дневној миграцији претходила миграција локалног типа, међусеоска или међуопштинска или чак међусреска на републичком нивоу те да су се становници доселили у одређено насеље како би им свакодневно путовање до РБК и Младеновца било ближе (Радовановић М.,1968).

Међузависност различитих облика миграција, односно како различити миграциони процеси делују један на други и у којим околностима једна форма кретања може узроковати другу, зависи од услова у којима се миграције одвијају. "Различити облици миграција различити су просторни одговори на исте силе деловања" (Skeldon R., 2006). Услови у којима се одвијају дневне миграције веома су битни за евентуалну трансформацију дневних миграција становништва у дефинитивну миграцију. Као одговор на промену услова (време, дистанца, трошкови путовања) може доћи до прерастања дневне у дефинитивну миграцију, али и преображаја дневног мигранта у не мигранта нпр. уколико се јави могућност запослења у насељу становања. Избор одређеног места становања и места рада, резултира у различитим облицима просторне покретљивости становништва. "Промена места рада или пресељење ствара нову комбинацију место становања - место рада, што значи да је дугорочно потребно или ново места рада или нова миграција" (Renkow M.,D. Hoover, 2000). Различита су размишљања истраживача на тему детерминанти које утичу на избор између дневне и дефинитивне миграције као и везе између ових облика просторне покретљивости становништва. Дневне миграције, промена посла и промена места пребивалишта могу бити замена једно за друго одражавајући прилагођавање доступним могућностима за рад и становање. Емпиријски резултати подржавају хипотезу да отказ и пресељење замењују једно друго у одржавању равнотеже дневних миграција. Укидање аутобуске линије или пораст цене бензина утицаће на појаву неравнотеже дневних миграција. Неки радници he се преселити или дати отказ да би до равнотеже поново дошло (Zax J.,1991), Одређени број аутора сматра да су дневне миграције замена за дефинитивне када је реч о мањим удаљеностима и унутрашњим миграционим токовима, али се надопуњују када је реч о дефинитивним миграцијама на веће удаљености односно о међурегионалној просторној покретљивости (Zax J.,1994, Holmes J., 1971). Гордон сугерише да су токови дневних миграција замена за миграције и да на удаљеностима до 100 миља $(160,9 \mathrm{~km})$ и до 50 миља $(80,4 \mathrm{~km})$ већина људи рађе мења путање дневних миграција него што се одлучује за селидбу (Gordon, 2003, према Renkow M., D. Hoover, J.Yoder, 1996). 
За настанак и тип просторне покретљивости становништва између два насеља од значаја су различити фактори. Утицај ових фактора зависи и од карактеристика појединца и домаћинства укљученог у миграциони процес. Допунска зарада у пољопривреди, као додатан извор прихода у насељу становања, који умањује нужност пресељавања, или високе цене некретнина у насељу рада економски су фактори који могу утицати на избор дневне у односу на дефинитивну миграцију. Организација простора такође може бити одлучујући фактор у избору између дефинитивне миграције и дневне миграције радне снаге. "Дневне миграције преовладавају у оним крајевима где је индустрија децентрализована, док седмичне и повремене дневне миграције па чак и дефинитивне миграције преовладавају тамо где је индустрија концентрисана у неколико градова" (Rоса О.,1986).

Пораст сложености веза између дневне и дефинитивне миграције и све већи обим дневних миграција на велике удаљености забележен у бројним земљама у протеклих десет година покушава се објаснити на различите начине. Најчешће се сматра да људи све више мењају један облик мобилности за други због пораста броја домаћинстава са двоје запослених тзв. two earner households, те да присуство два радника у домаћинству делује да се ова домаћинства peђе селе (Green A.E., T.Hogarth, R.E.Shackelton, 1999; Mulder 1993, према Camstra R.,1996). Повеһање економске активности жена које је условило пораст броја домаћинстава са два радника један је од фактора који доводи до све сложенијих односа између места рада и места становања. Питање је да ли локална средина може да обезбеди радна места за одговарајуће квалификације више чланова домаћинства. Развој саобраћајне мреже, средстава превоза и информационих технологија, у савременим условима, такође омогућава појединцима и домаћинствима све већу флексибилност у погледу тржишта рада. У том случају један члан домаћинства може да се определи да свакодневно путује до места рада, како би се избегла дефинитивна миграција за цело домаһинство. Становање у једном и рад у другом насељу омогућавају како појединцу тако и домаћинству да искористе предности и једног и другог насеља у погледу услова за живот (мање загађена животна средина нпр.) и могућности које оба насеља пружају за запослење и становање, без већих промена у животу и потребе за адаптацијом које дефинитивна миграција подразумева. Са економског аспекта, до дневне миграције насупрот дефинитивној може доћи ако су трошкови превоза једног члана домаћинства прихватљивији за домаћинство од евентуалних трошкова пресељења целог домаћинства. Закс указује да домаћинства са мањом вероватноһом мењају место пребивалишта и рада у оквиру датог географског региона него што само мењају место пребивалишта или место рада (Zax J., 1994). "Домаћинства са два запослена често мењају миграцију за дневне миграције на дуже стазе као део стратегије против несигурности коју носи дефинитивна миграција за домаһинство као целину" (Pooley C., J.Turnbull, M.Adams,2005). Испитивања домаћинстава о начину на који активно становништво доноси одлуку о месту становања и месту рада, показала су да је за већину радника место становања а не рада имало приоритет при одлучивању (Hanson S., G.Pratt,1988). Често се подразумева да је каријера мушкарца доминантна у односу на каријеру жене. Када је реч о прерастању дневне у дефинитивну миграцију Камстра потврђује да је за пресељење на дуже дистанце претежно пресудан посао мужа, а за пресељење на краће дистанце промена посла жене. Издваја две групе жена - веома осетљиве на дистанцу дневне миграције, које hе пре дати отказ него се преселити у случају повећања дистанце дневне миграције и мање осетљиве које hе пре задржати посао. Докази указују да је и друга група жена и даље осетљивија од мушкараца на пораст времена потребног за путовање до посла, покушавајући да ограничи своје време дневне миграције. После дефинитивне миграције дистанца дневне миграције је порасла више за жене у свим категоријама што упућује да 
је пресељење претежно диктирао посао мужа. Тиме се потврђује хипотеза Каина да домаћинства прилагођавају своје место становања локацији места рада мушкарца, док жена прилагођава своје место рада локацији куће, са закључком да у савременим условима традиционалније жене у случају повећања времена потребног за путовање до посла, дају отказ а модерније све више путују на веће дистанце. Сматра се генерално да жене осећају већи притисак да нађу место пребивалишта близу посла, те да им је због обавеза у домаћинству тзв. хипотеза о одговорности у домаһинству теже да свакодневно путују на већим удаљеностима. Камстра указује да је вероватноћа дефинитивне миграције снажније везана за дистанцу дневне миграције код жена него код мушкараца када се контролишу друге разлике у групи. Утврђено је да вероватноһа да дневна миграција прерасте у дефинитивну зависи и од година дневног мигранта и степена урбанизације насеља. Жене старости 15-24 године имају вероватноћу дефинитивне миграције од $16,9 \%$ а оне старије од 35 година само $4,4 \%$. Вероватноһа миграције за жене у градовима износи $12,9 \%$, а у другим насељима $9,4 \%$ што може бити и под утицајем већег броја жена у градској популацији. За жене које путују свакодневно на посао на већим дистанцама шансе за миграцију су $85 \%$ док је код мушкараца то $55 \%$ (Camstra R.,1996).

Међу факторима који утичу на избор типа просторне покретљивости становништва јесу и старосна структура и фаза животног циклуса дневних миграната. Истраживања показују да радници млађи од 35 година имају највећу вероватноћу скорије промене места становања (Romani J., J.Surin, M.Artis,2003). Већина испитаника у Брусу, Алексинцу и Врању који су намеравали да замене дневну миграцију дефинитивном, време дефинитивне миграције везали су за значајне догађаје у животном циклусу (склапање брака, полазак деце у школу) (Стаменковић, 1989; Стаменковић С. и др.,1995).

Тенденција замене дефинитивне миграције за дневну миграцију, поред структуре домаһинства и деомграфских обележја дневних миграната везана је и за развој саобраћаја, урбани развој, стање на локалним и регионалним тржиштима рада и некретнина, као и спремност послодаваца да одобре барем делу радника већи степен слободе у смислу где и када ће се посао обавити (Green A.E., T.Hogarth, R.E.Shackelton, 1999). Саобраћајни услови за одвијање дневних миграција становништва и време потребно за путовање такође утичу на избор типа миграције. Ови услови зависе од развијености саобраћајне мреже али и доступности и избора одређене врсте превоза. С обзиром да је у неку руку напорно путовати далеко сваки дан на посао и назад, сматра се да одвијање дневних миграција на великим удаљеностима повећава вероватноћу да дође до дефинитивне миграције. Резултати једног истраживања показују да повећање дистанце дневне миграције за $10 \mathrm{~km}$ смањује очекивани останак на истом послу за две године (Van Ommeren J., P.Rietveld, P,.Nijkamp, 1999).

Бројна истраживања показују да претходни трендови мобилности повећавају вероватноћу да поново дође до неког облика миграције. Сматра се да након митрације појединац добија нове информације и суочава се са релативно нижим трошковима за додатну мобилност. Елијасон и други на примеру Шведске показују значајне разлике у миграционом понашању и миграционом потенцијалу између оних који мигрирају/дневно мигрирају по први пут и оних са претходним миграционим искуством. Особе са претходним миграционим искуством/учешћем у дневним миграцијама имају већу вероватноћу да поново учествују у одговарајућем облику просторне покретљивости становништва (Eliasson K., U.Lindgren, O.Westerlund, 2003). Алонсова оригинална формулација моноцентричног модела из 1964. године и већина модела заснованих на њему предвиђају да ће радници променити своје место становања у намери да смање време потребно за путовање до посла. На основу ове теорије могло 
би се предвидети да ће радници који су се скоро преселили имати мању вероватноһу за дневним миграцијама од осталих и обрнуто. На примеру Шпаније доказано је управо супротно. Радници који су се преселили у посматраном периоду имали су већу вероватноћу за учешћем у дневним миграцијама од оних који се нису селили (Artis M., J.Romani, J.Surinach,2000).

Реитсма и Вергосен истичу условну улогу коју имају дневне миграције у одлуци o дефинитивној миграцији. Они сматрају да је вероватноћа дефинитивне миграције вероватноһа достизања прага толеранције дневне миграције који се дефинише као максимум времена које је лице спремно да утроши на дневну миграцију. Када могућа промена места рада узрокује пораст дистанце дневне миграције, ова дистанца може досећи тачку када hе деловати као граница изнад које hе дневна миграција бити неприхватљива. У оваквим случајевима дефинитивна миграција је неопходна. Када миграцију не прати промена места рада постоји могућност пресељења искључиво из стамбених разлога или пресељење зато јер се мора бити ближе постојећем месту рада 3бог потреба датог посла. Резултати модела показују да дуге дневне миграције повећавају вероватноћу за миграцију. Код дневних миграната који су се преселили због посла потенцијално време је прелазило време толеранције. Потенцијално време дневне миграције је оно које би испитаник морао да утроши да се није преселио (Reitsma R., F.Vergoossen, 1987).

Слика 3. Три концептуална типа миграције
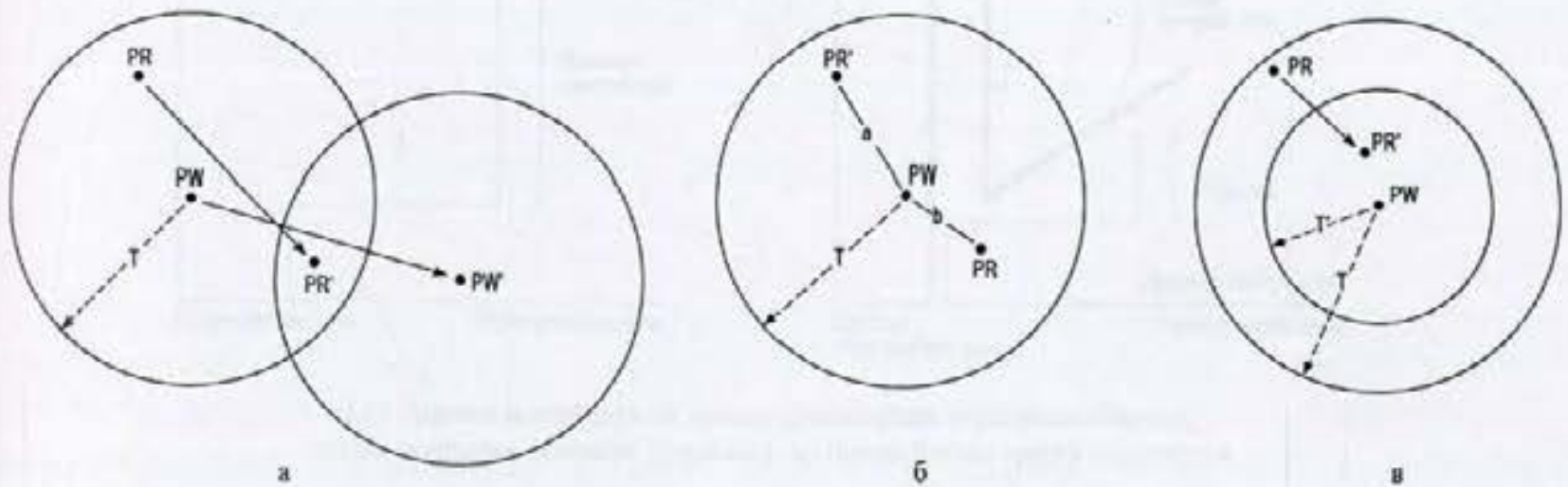

Reitsma R., F.Vergoossen, 1987.

$\mathrm{A}=$ радиа мигранија са променом места рада $\mathrm{D}=$ резиденцијалиа миграција

B=-радна митрација без промене места рада
$\mathrm{PR}$ - изворно место становања

PR'= пово место станована

$\mathrm{PW}=$ изворно место рада

$\mathrm{PW}^{\prime}=$ ново место рада

$\mathrm{T}=$ толеранција дневне митрације у почетној ситуацији T'= нова толеранција дневне мигращије

И други аутори сматрају да је достизање одређене дистанце дневне миграције кључно за замену дневне миграције дефинитивном. "Дневна миграција неће прећи у дефинитивну све док се не пређе критична изохрона" (Rouwendal J., 2004). Колики је праг толеранције дневне миграције односно која је критична изохрона и шта их одређује тек треба да се истражи. Сигурно је да је праг толеранције дневне миграције различит за различите категорије становништва. Везу између дневних и дефинитивних миграција, запажајући међузависност између ове две врсте мобилности становништва 
садрже и типологије просторне покретљивости становништва других аутора као што су Гавризенски и Термоте (Gawryszenski 1978, Termote, 1980, према Roca O.,1986).

У бројним земљама примећена је последњих година тенденција замене дефинитивних миграција дугим дневним миграцијама. Ова појава нарочито је изражена у Великој Британији. Постоје различите могуһности развоја везе између дневне миграције и дефинитивне миграције, а нарочито када је реч о дневним миграцијама на дужим релацијама које су генерално неодрживе на дужи временски период.

Слика 4. Одрживост дневних миграшија на дуже стазе: могућа решења
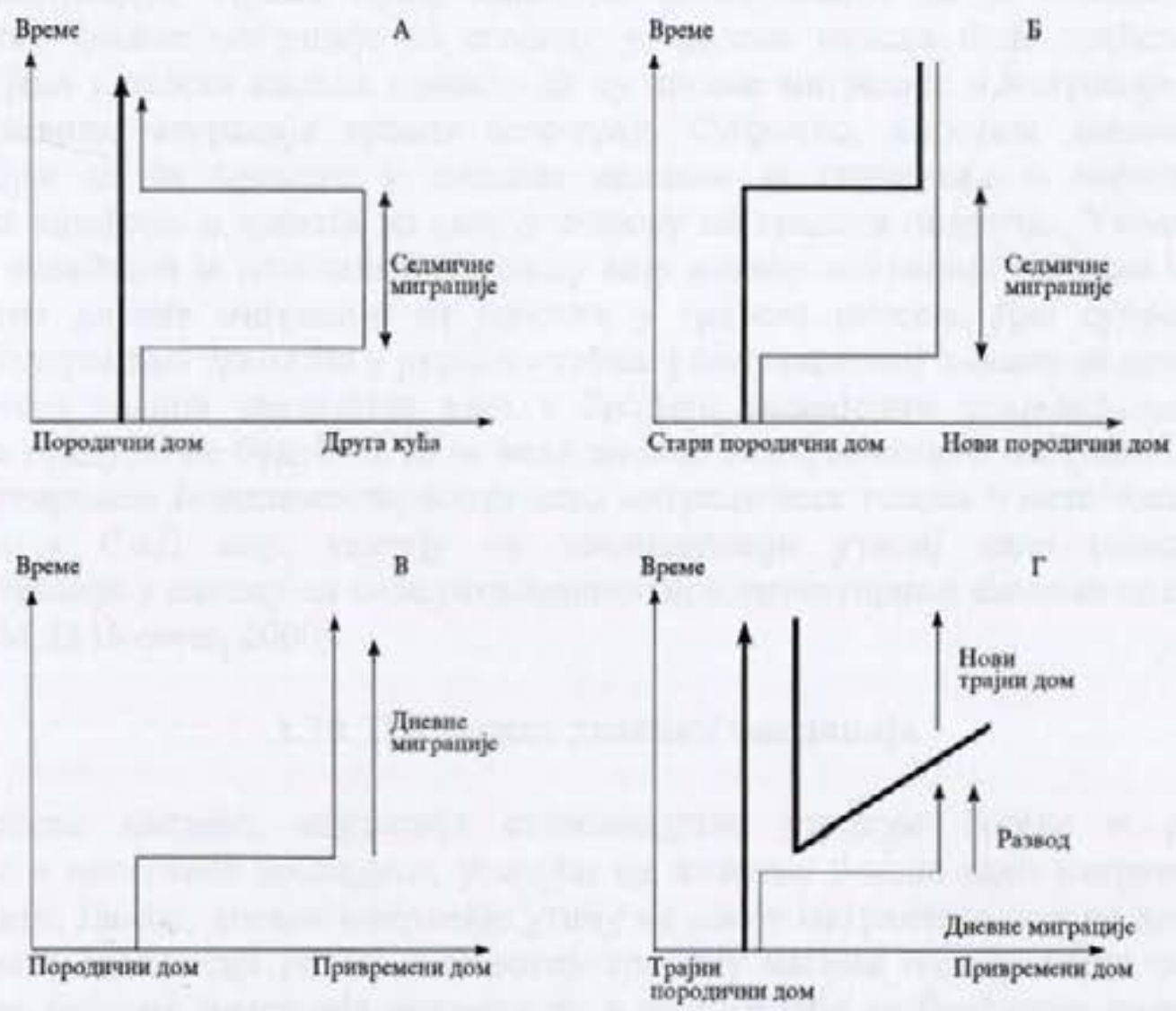

(А) Днсвна миграпија на дужим релапијама ограничен период. затим повратак дневном путовању до посла ближе месту становања

(Б) Дневна миграшија на дужим реланијама као трагзицијска фаза, праһена релокацијом у ново подручје и дневном миграцијом

(B) Дневна миграција на дужим релашијама на нсодређен период, без релоканије, успоставља се двојна локација домаћинства

(Г) Дневна миграшюја на дужим релашијама ограничен период, праһен прекидом породичних веза (развод) и трајним пресељењем

Green A.E., T.Hogarth, R.E.Shackelton, 1999.

Eверс (Evers,1989 према Renkow M.,D.Hoower, 2000) у анализи појединачних тржишта рада у оквиру регионалних тржишта рада уводи концепте субституције замене и комплементарности - допуне између дневне и дефинитивне миграције. За одређено подручје замена би се емпиријски манифестовала као негативна веза између дивергентне дневне миграције и имиграције на одређеном простору, или као позитивна веза између конвергентне дневне миграције и имиграције. До замене између миграције и дневне миграције дошло би уколико би позитивна локална дешавања смањила 
преференције домаћинстава за дневним миграцијама ван одређеног подручја и повећала cтопу усељавања. Допуна између дневне миграције и миграције дефинише се као позитивна веза између дивергентне дневне миграције и имиграције или негативна веза измеђ) конвергентне дневне миграције и имиграције. Дневне и дефинитивне миграције могу бити допуна у случају када су дневне миграције облик привременог прилагођавања околностима док не дође до дефинитивне миграције. Концепт замене или допуне између миграције и дневне миграције представља уобичајен начин за мерење степена исправности два супротна става у објашњавању трендова у популационој динамици село-град, регионалне хипотезе о преструктуирању и хипотезе o деконцентрацији. Према првој хипотези за очекивати да је слабљење токова дивергентне дневне миграције из сеоских у градска насеља буде праһено са нето имиграцијама у сеоска насеља односно да су дневне миграције и миграције замена за токове дневних миграција правца село-град. Супротно, хипотеза деконцентрације усредсређује се на промене у жељама везаним за становање и порасту значаја предности комфора и живота на селу у односу на градска подручја. Уколико је ово случај за очекивати је позитивну допунску везу између миграције у сеоска подручја и дивергентне дневне миграције из сеоских у градска насеља. Две супротстављене хипотезе о узроцима трендова у рурално-урбаној популационој динамици присутним од седамдесетих година двадесетог века у бројним развијеним земљама имплицирају различите предуслове будућности за везу дневне и дефинитивне миграције. Ренков и Хувер тестирањем комплементарности нето миграционих токова и нето токова дневне миграције у САД нпр. указују на доминантнији утицај сила резиденцијалне деконцентрације у односу на силе регионалног преструктуирања економске активности (Renkow M.,D.Hoower, 2000).

\subsection{0. Последице дневних миграција}

Процес дневних миграција становништва узрокује бројне и разноврсне позитивне и негативне последице, утичући на животне услове како миграната тако и немиграната. Наиме, дневне миграције утичу на самог мигранта, али и на демографски и друштвено-економски развој и животну средину насеља између којих се одвијају. Последице дневних миграција видљиве су и на подручју саобраћајних путева између ове две дестинације. Импликације дневне мобилности активног становништва и школске/студентске омладине видљиве су у економским, социјалним, културним и бројним другим сферама живота. Поред очигледних (или лако уочљивих) последица дневних миграција, као што су проблеми везани за повећање обима саобраћаја, буке и емисије издувних гасова у одређеним периодима дана, дневне миграције се посредно одражавају на број, размештај, и структуре становништва и домаһинстава преласком дела дневних миграната у дефинитивне.

Дневне миграције имају различите импликације на локални и регионални развој, а самим тим и на развојне политике и просторно планирање. Свакодневно путовање дела становништва из једног насеља у друго насеље, као позитиван ефекат има смањење потребе за улагањима у комуналну и стамбену инфраструктуру насеља рада/школовања (најчешће градова). С друге стране, преоптерећење саобраћајница на правцима дневних миграција може проузроковати потребу за њиховим чешћим и непланским поправкама и већим улагањима у саобраћајну мрежу и возни парк јавног саобраћаја.

Физиономске последице дневних миграција становништва су највидљивије и огледају се у промени морфолошко-просторне (физиономске) структуре насеља становања и рада, односно физиономије и општег изгледа насеља. У насељима 
становања мења се изглед кућа и других објеката, а често и намена разних пратећих објеката, као и изглед и намена земљишних парцела. Радовановић даје пример двојног развоја насеља Рудовци у рударском басену Колубара, где се поред старог села које се развија својим током, развијао и други део насеља са модерно изграђеним становима (Радовановић М.,1968). Долази до промене правца просторног развоја насеља, односно до просторног ширења насеља дуж главних саобраћајница, ради боље саобраћајне доступности. Једна од негативних последица дневних миграција радне снаге у насељима рада јесте учестала појава дивље градње, као начин на који дневни мигранти желе решити стамбено питање у насељу рада.

Популационе последице дневних миграција становништва видљиве су у променама основних компоненти демографског развоја, променама у структури становништва и домаћинстава и густини насељености. Поред промена у структури становништва према делатности, дневне миграције могу да утичу и на нека друга обележја становништва. "Неке демографске промене као што је нпр. промена етничког састава насеља постепено су извршене и путем дневних миграција становништва, с обзиром да ове привремене миграције обично воде ка пресељењу у насеље рада" (Stanković V., Žiž̌ić M., Kapuran S., 2000).

Економске последице дневних миграција становништва везане су само за активне дневне мигранте. једна од позитивних економских последица дневних миграција јесте побољшање животног стандарда породице дневног миграната. Имајући у виду да су у Србији дневне миграције радника првенствено узроковане личним (породичним) потребама и имају економску оправданост (Лукић В.,2006) дневни мигрант најчешће подиже стандард домаћинства обезбеђујући домаћинству примања по правилу већа од оних које би могао зарадити у локалној средини. Ефекти дневних миграција на локални економски развој могу бити различити, и њихов утицај може варирати током времена, те тако допринети повећању или смањењу социоекономских разлика између насеља становања и насеља рада. Улагање дела дохотка дневних миграната у насеље становања свакако је позитиван процес. Коришћење дохотка створеног у граду за стамбену изградњу, побољшање комуналне и социјалне инфраструктуре села неки аутори називају повратном урбанизацијом (Friganović M., 1968; Vresk M., 1990). Као последица дневних миграција могу се смањити обрадиве површине, или доћи до модернизације пољопривредне производње (куповина механизације и пољопривредне опреме). Такође долази и до промена у структури пољопривредне производње и културама које се гаје. У Словенији нпр. је код радника који путују на краһе удаљености примећено да уместо да занемаре или напусте пољопривредну производњу претварају је у монокултуру за урбано тржиште (Klemenčić V., 1964). Међутим домаһинства дневних миграната могу и да занемаре обрађивање земље или је чак оставе на угару уколико им приходи, остварени најчешће у граду, учине рад на имању непотребним.

Meђу негативним економским последицама дневне миграције јесте смањење продуктивности услед губитака због кашњења радника на посао, нарочито уколико се превозе градским превозом, чешћих одсуствовања због боловања (као последице заморености услед путовања и недостатка времена за одмор), или обављања сезонских пољопривредних послова уколико је реч о радницима који се допунски баве пољопривредом.

Последњих година су честа истраживања на тему психо-социјалних последица свакодневног путовања дневних миграната, и квалитета њиховог живота уопште. Дневне миграције могу да се одразе на здравствено стање радника и чешће изостајање са радног места (боловање) као резултат умора услед свакодневног путовања. Постоје сазнања да радници постају мање продуктивни са порастом дистанце дневне миграције 
(Zenou Y., 2002). Истраживање проведено на узорку од 1.167 индустријских радника у Италији показује да дневни мигранти имају стреснији живот од осталих радника (Costa G.,L. Pickup, V. Di Martino, 1988). И мушкарци и жене дневни мигранти осећају већи стрес приликом свакодневног путовања до радног места у случају када има је вожња непредвидљива (нередован железнички превоз) (Evans G., et al., 2002). Мањак слободног времена услед свакодневног путовања одражава се на друге аспекте живота дневног мигранта, а тиме и на породичне односе, јер су чланови породице дуже раздвојени и проводе мање времена заједно. Једна од социјалних последица дневних миграција стога је у неким случајевима и слабљење брачних односа и улоге родитеља у образовању и одгоју деце. Наравно, има истраживања и са супротним резултатима. Полазеһи од принципа да је место рада партнера, у случају када су оба супружнника запослени, ретко за обоје у месту становања, испитивање Бункера на принципу узорка две групе парова, од чега у једној групи нису били дневни мигранти а у другој јесу, показало је да нема значајнијих разлика по питању стреса. Парови који учествују у дневним миграцијама најчешће су се изјашњавали да сматрају такво решење за привремено док се не јави прилика за одговарајући посао ближе (Bunker B., et al.1992).

Развојно деловање дневних митрација на подручја њиховог утицаја видљиво је у различитим сферама живота. Једна од позитивних последица дневне миграције јесу промене у начину живота које дневни мигранти доносе из насеља рада у насеље становања. Преко миграционе мреже преносе се информације и идеје између насеља рада и насеља становања. С обзиром да дневни мигранти најчешће раде у већем, градском насељу усвајањем градских норми и погледа на живот, променама навика и начина живота они су главни носиоци промена у сеоским насељима. Спенсер истиче да су мигранти средство - посредници културних промена, односно да је мигрант културни посредник (Spencer, 1970 према Swindell K., R.Ford,1975). Истраживање у Словенији седамдесетих година прошлог века показало је да су она села која су имала највећи степен прихватања иновација имала и највећи удео дневних миграната сељака радника (Golob, 1976, према Roca O.,1986). У истраживању промена и карактеристика материјалне, духовне и друштвене културе становништва захваһеног индустријализацијом шездесетих година 20. века и Радовановић М. је уочила посредан утицај дневне миграције на живот и карактеристике самог насеља у коме сељаци радници живе, и још шире на развој комуне у чијим се оквирима насеље налази. "Стално кретање људи у две различите средине у аграрносељачкој и индустријској има одлучујући утицај на обликовање неких нових одлика у менталитету, обичајима и навикама" (Радовановић М., 1968).

Елементи и фактори дневног миграционог процеса који су разматрани у првом поглављу рада имају различите импликације на обим, правце и структуру дневних миграционих токова, у зависности од простора одвијања дневних миграција, односно за различите регионе и државе. Стога је у наредном поглављу приказан кратак преглед развоја, обима и праваца дневних миграција и структурних карактеристика дневних миграната у Србији и свету. 


\section{П ДНЕВНЕ МИГРАЦИЈЕ СТАНОВНИШТВА У СРБИЛИ ${ }^{+}$И СВЕТУ}

\section{1. Развој и обим дневних миграција}

Обимније дневне миграције становништва у Европи забележене су прво у западним земљама у другој половини 19. века, док су у земљама источне Европе дневне миграције постале значајнијег обима тек после Другог светског рата. У Србији дневне миграције постају интензивније 60 -их година прошлог века, а што је последица пре свега убрзане индустријализације и урбанизације после Другог светског рата.

Временом токови дневних миграција активног становништва постају све обимнији у већини земаља. Један од фактора који је утицао на повећање интензитета дневних миграција јесте пораст броја породица у којима зарађују два члана, односно повећано учешће жена на тржишту рада. Око 100 милиона радника у Европи 1988. године били су дневни мигранти (Costa G., L. Pickup,V. Di Martino,1988). У готово свим земљама чланицама OECD-a токови дневних миграција активног становништва обимнији су од унутрашњих миграција. Између $1 \%$ и $16 \%$ запослених у земљама OECD-a су дневни мигранти. У Великој Британији, Немачкој и Јапану $16 \%$ запослених чине дневни мигранти, док је стопа дневне миграције у Шпанији релативно ниска. Разликама у уделу дневних миграната у укупном броју активног становништва на нивоу појединачних земаља доприносе методолошке разлике (OECD,2005; www.japanguide.com). У напред наведеним земљама са великим обимом дневне миграције главни град се сматра засебним регионом, па се сва кретања изван њега сматрају за међурегионалне дневне миграције. У балтичким земљама Естонији, Летонији и Литванији око 20\% радне снаге не ради у општини у којој живи (Hazans M.,2004). У Италији 33\% радника чине дневни мигранти (Cristaldi F.,2005), што је знатно више него у Србији. Суседна Хрватска такође има већу стопу дневне миграције од Србије. Према Попису становништва из 2001. године од укупног активног становништва у Хрватској $29,7 \%$ су били дневни мигранти (www.dzs.hr). И у бившој Југославији Хрватска је, поред Словеније, имала удео дневних миграната у укупном броју радника који је био већи од просека за Србију и изнад просека за Југославију.

У дневним миграцијама у Србији (без Косова и Метохије) 2002. године учествовало је 793.517 или 10,6\% од укупног становништва. Од укупног броја радника $21,4 \%$ чинили су дневни мигранти. Ван насеља у коме станује радило је 405.192 или $20,9 \%$ радника у Централној Србији, односно 159.862 или $22,8 \%$ радника у Војводини. Поред тога, дневно је мигрирало око 160.000 ученика и студената у Централној Србији и 67.000 у Војводини. (РЗС, 2004). Према подацима Пописа становништва из 1961. године у Централној Србији је било 176.402 дневних миграната или $22,4 \%$ радника, односно 51.235 или 13,3\% радника у Војводини (С3С,1967).

Најдинамичније дневне миграције становништва у Србији биле су у периоду интензивног привредног развоја земље, осамдесетих година прошлог века. Од тада се дневне миграције прилично уједначено одвијају на простору Војводине, док су на простору Централне Србије забележене веће варијације у уделу дневних миграната у запосленом становништву током времена. Трансфер становништва из пољопривредних у непољопривредне делатности резултирао је високим порастом удела дневних миграната у запосленом становништву Војводине у периоду 1961-1971. година. Након овог периода удео дневних миграната у запосленом' становништву Војводине временом је достигао вредности за Централну Србију да би у последње две деценије

\footnotetext{
+ Подаци се односе на територију Републике без Косова и Метохије.

${ }^{9}$ За претходне године радници а за 2002 . годину активно становништво које обавља занимање.
} 
дневне миграције радника Војводине постале чак интензивније у поређењу са Централном Србијом.

Графикон 1. Удео дневних миграната у запосленом становништву (\%)

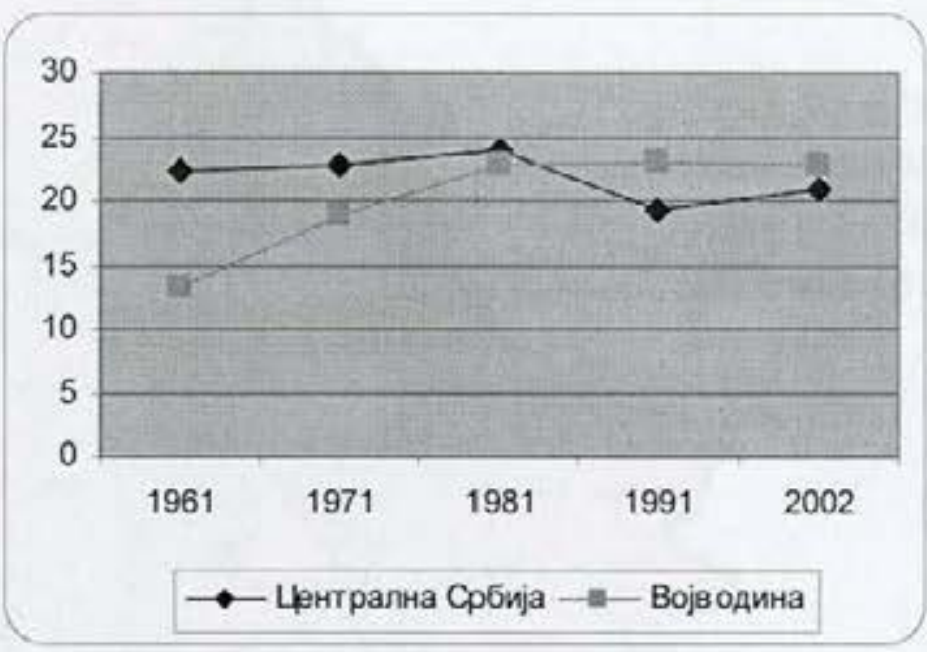

Извор података: СЗС, 1967; Р3С, 2006а; Р3С, 2004.

У последњих двадесет година прошлог века у највеһем броју општина Србије дневни мигранти чинили су до $30 \%$ од запосленог становништва. Већи број општина са учешћем дневних миграната у запосленом становништву, између тридесет и педесет одсто од запосленог становништва, забележен је током осамдесетих година двадесетог века.

Табела 5. Класификација општина Србије према уделу дневних миграната у запосленом становништву

\begin{tabular}{|c|c|c|c|}
\hline Удео дневних миграната & \multicolumn{4}{|c|}{ Број општина } \\
\cline { 2 - 4 } у запосленом становништву (\%) & 1981 & 1991 & 2002 \\
\hline $0,1-15$ & 30 & 43 & 43 \\
\hline $15-30$ & 62 & 93 & 89 \\
\hline $30-50$ & 53 & 19 & 19 \\
\hline $50-70$ & 11 & 6 & 10 \\
\hline $70-85$ & 5 & & \\
\hline
\end{tabular}

Извор података:Р3С,2006а; Р3С, 2004.

Промене удела дневних миграната у запосленом становништву, на нивоу општина Србије, могу се видети на картама бр.1, бр.2 и бр.3. 3бог упоредивости података уважене су административно-територијалне промене које су наступиле у периоду 1981 -2002. година и подаци су сведени на територијални ниво из 2002. године. Међутим због методолошких измена у концепту пописивања укупног становништва и методолошких измена које су учињене код активног становништва (међу којима је и примена конщепта тзв. текуће активности који друштвено-економске карактеристике становништва везује за краћи временски период који претходи попису) у Попису становништва из 2002. године резултати ипак нису у потпуности упоредиви.

Општине Црна Трава, Сјеница, Нови Пазар, Тутин, Вршац, Бечеј, Сента, Нови Кнежевац и Бач чине групу општина у Србији са константно малом дневном просторном покретљивошћу радне снаге. Групу општина у којој дневни мигранти чине више од половине запосленог становништва још од осамдесетих година прошлог века, чине београдске опптине Барајево, Гроцка, Дољевац, Лазаревац и општина Нишка Бања. Према Попису становништва из 2002. године као простори ниске дневне просторне покретљивости радне снаге истичу се области у источној и југозападној Србији и мањи појасеви у Шумадији и Поморављу. 


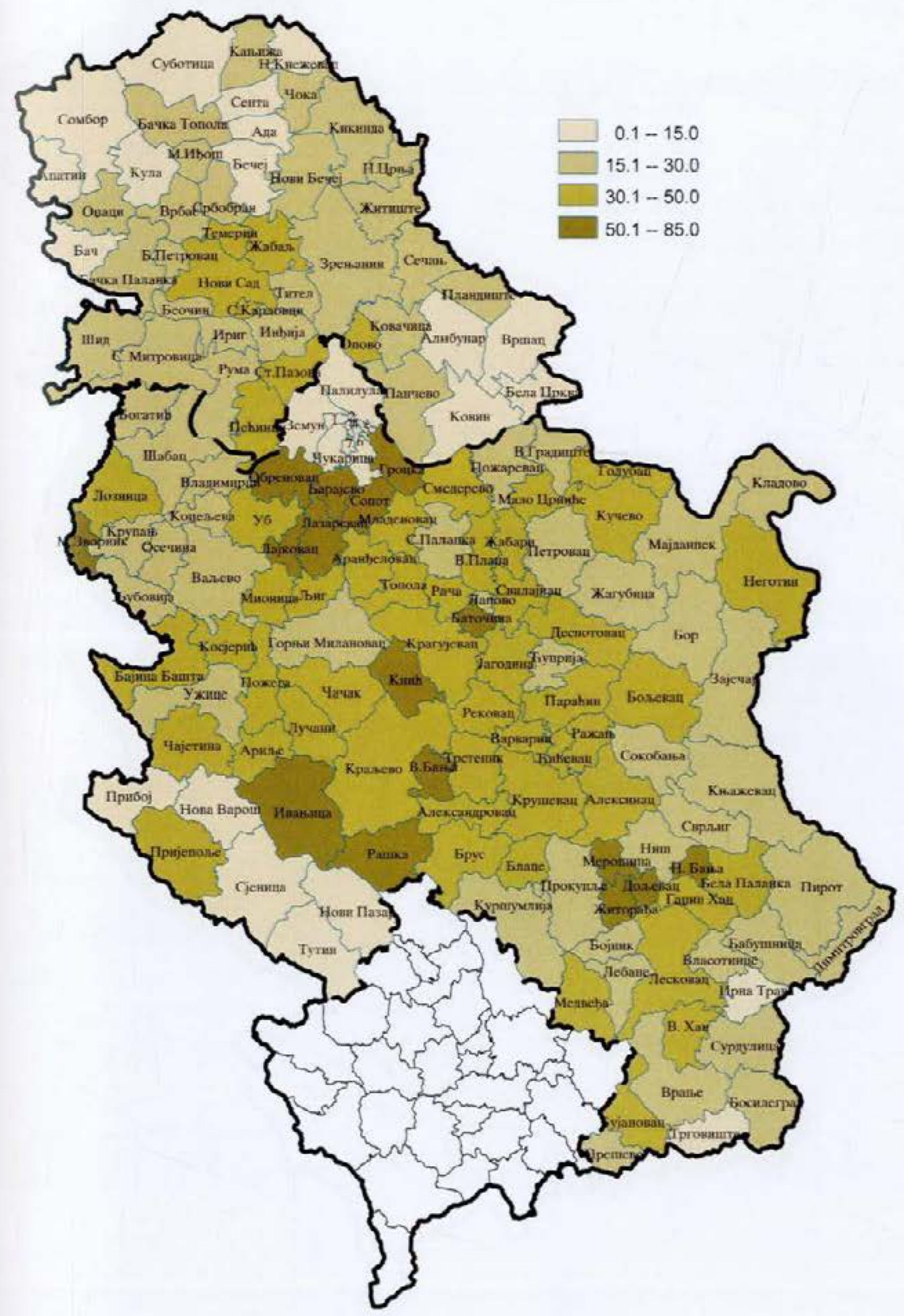

Карта 1. Опитине у Србији према удепу дневних митраната у запосленом становништву 1981. год. (\%) 

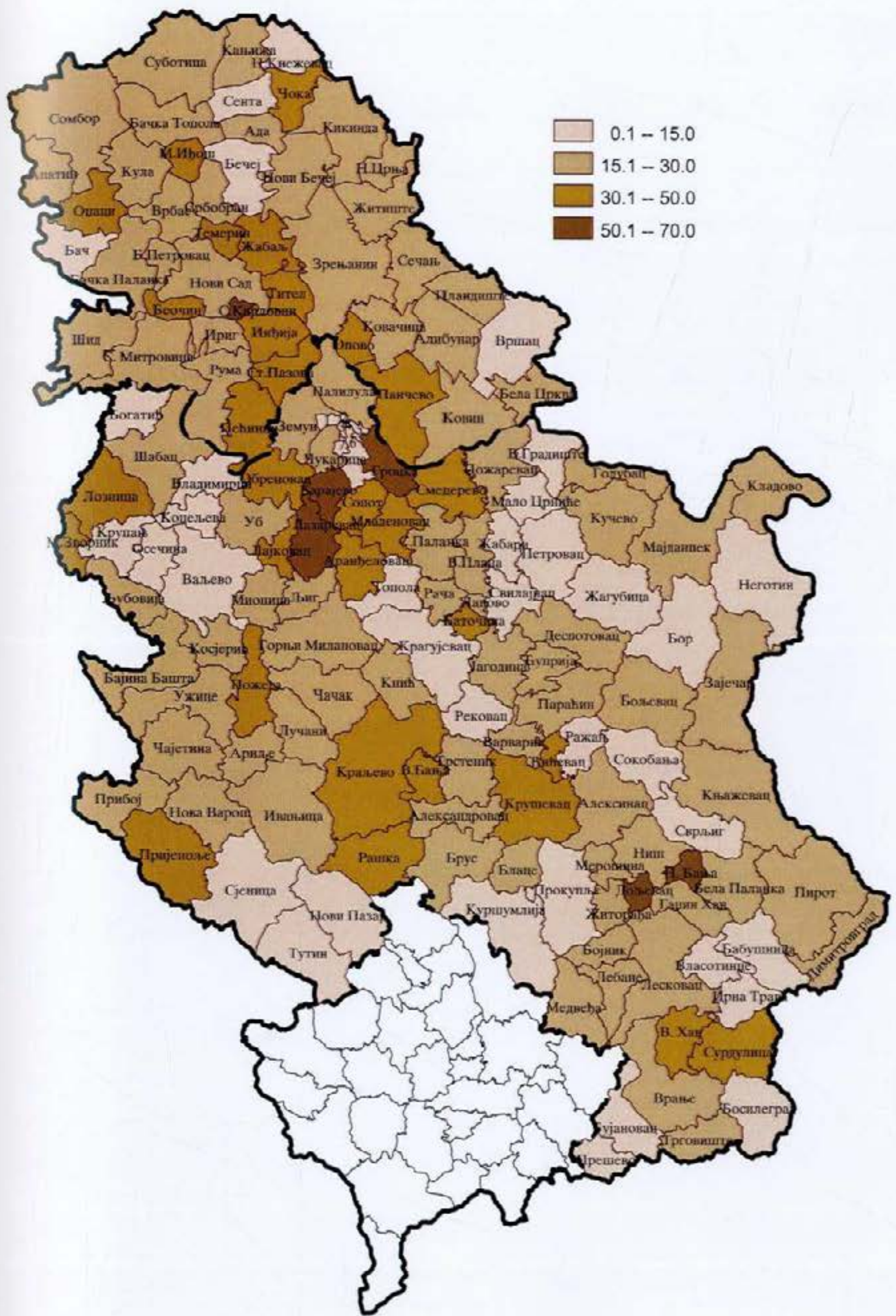

Карта 2. Општине у Србији према уделу дневних миграната у запосленом становништву 1991. год. (\%) 


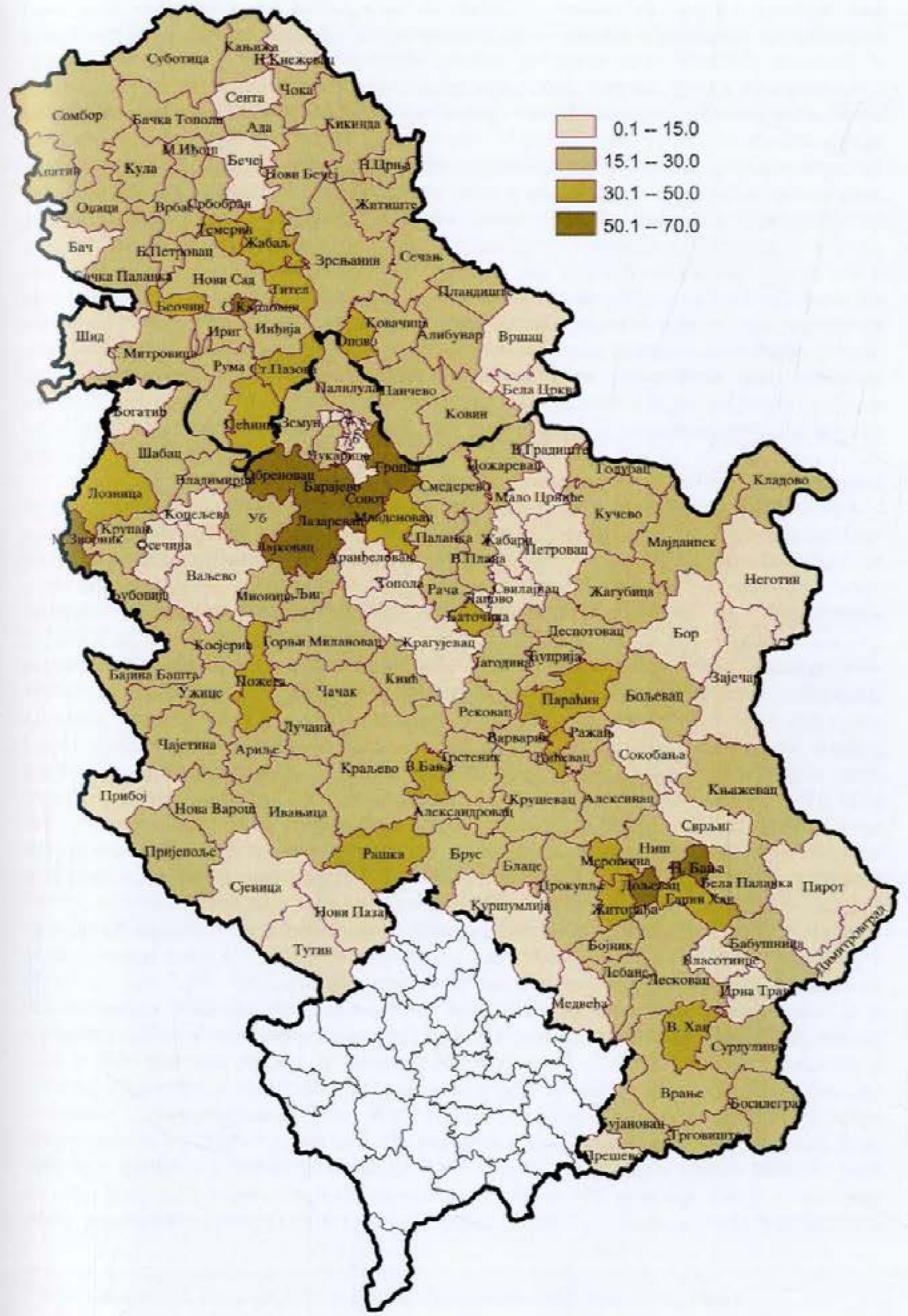

Карта 3. Отштине у Србији према уделу дневних миграната у запосленом становништву 2002, год. (\%) 
Објављени резултати Пописа становништва у Хрватској 2001. године бележе и категорију седмичних миграната, како активног становништва тако и студената. Ова категорија је приликом пописа становништва у нашој земљи обухваћена дефиницијом дневног мигранта ${ }^{10}$, тако да седмични дневни мигранти нису посебно исказани у објављеним резултатима Пописа становништва из 2002. године. Раније су седмичне и повремене миграције, као облици просторне покретљивости становништва, биле специфичне за неразвијене земље или регионе. У савременим условима живота и рада седмичне и повремене миграције активног становништва у многим земљама израз су све веће флексибилности у погледу места рада и места становања услед промењених услова функционисања предузећа и појаве нових профила занимања. Транзиција из индустријске у информациону економију тј. повећана употреба компјутера, телефона, телефакса и интернета отворила је могућност за рад код куће (од куће). Место али и време обављања радне делатности постају све мање ограничени и унапред одређени. На тај начин се смањила потреба за дневним миграцијама радника који се баве одређеним занимањима, односно дошло је до трансформације дела дневних миграција у неки други облик просторне покретљивости становништва (повремене или седмичне миграције тј. путовање до места рада само одређеним данима или делом радне недеље а осталим данима рад код куће). Самим тим повећала се и комплексност веза између места становања и места рада.

Дневне миграције становништва у периоду после Другог светског рата одвијале су се у светлу промена економске структуре радне снаге и трансфера становништва из пољопривредних у непољопривредне делатности, а у складу са повећаним потребама индустрије за ангажовањем радне снаге. Већина дневних миграната из сеоских подручја у то време и даље се бавила пољопривредом, што је утицало на релативно мало смањење руралног становништва тзв. индустријализација са недовољном урбанизацијом. Ова појава је била карактеристична за Јужну Европу, где су регистроване веће стопе индустријализације од урбанизације нарочито у периоду 19501970. година (Roca O., 1986). За разлику од ових првобитних дневних миграција активног становништва у свету и код нас, када су дневни мигранти били двоструко радно ангажовани, у смислу рада на послу и рада на пољьпривредном имању, савремене дневне миграције одликује све већи број радника који раде код куће један или више дана у недељи и долазе на посао повремено, у зависности од потребе. "Рад код куће, који није рад на имању, феномен је нашег времена" (Pisarski A., 2002). Према истраживању из 1999. године проведеном у европским земљама, највећи удео радника који раде код куће (по дефиницији барем један цео дан у току недеље) имала је Финска $10,8 \%$, а затим Холандија $8,3 \%$ и Шведска $8 \%$. Године 2001. више од $5 \%$ укупног економски активног становништва у Великој Британији (9\%), Немачкој и Израелу радило је код куће. У Италији и Норвешкој код куће је радило $4 \%$ становништва, а у Бугарској око 2,5\%. Запажена је и појава да велики број ових радника ради на више радних места. Највећи број запослених који раде на више места забележен је у Бугарској (25\%), а најмањи у Израелу (12\%). У Немачкој, Италији и Норвешкој између $15 \%$ и $20 \%$ радника радило је на више радних места. Значајан проценат радника у Великој Британији и Норвешкој који раде код куће су лица која самостално обављају делатност (www.eurescom, The Rac Foundation,2003). Према подацима Пописа становништва из 2000. године око $3 \%$ радника у САД остаје код куће да ради, и не учествује физички у дневној миграцији. У 29 округа САД-а $20 \%$ и више радника ради од куће, док у 158 округа код куһе ради између 10\% и $20 \%$ радника. Реч је о претежно ретко насељеним сеоским просторима (Pollard К.,2002). Анализа структуре радника

\footnotetext{
${ }^{10}$ Види методолошка објашњења Књ.13 Пописа становништва 2002. године (Р3С,2004а).
} 
који раде код куће открива да су у САД нпр. радници који раде код куһе најчешће становници великих градова и раде за велике компаније, а баве се банкарством, осигурањем и комуникацијама. У структури радника који раде код куће $65 \%$ су мушкарци, мада овај тренд све више захвата и женску популацију (од радника код куһе који су започели рад у претходној години више је жена него мушкараца). Радници који раде код куће су старији од 25 година, са просечном старошћу око 40 година. Оним данима када не раде од куһе $80 \%$ ових радника путује на посао. Њихова просечна удаљеност до посла у једном смеру већа је од просечне удаљености до посла радника дневних миграната који не раде никада код куће. Велики проценат радника који не раде код куһе (39\%) такође је заинтересован за рад код куће као опцију убудуће, док је $13 \%$ испитаника изјавило да им је могућност за рад код куће веома важна при избору будуhеr посла (Nilles J., 2000).

Популација која обавља посао код куһе, као појава за сада карактеристична за развијене земље и повећану употребу информационе технологије, није истраживана са аспекта демографске науке код нас. Делимично је томе узрок што је ова појава код нас тек у зачетку, али је сигурно и да недостатку оваквих истраживања доприноси непостојање релевантних података о овој категорији запослених. Сазнања о структурама становништва које ради код куће значајна су како са теоретског тако и са практичног аспекта. Поред смањења обима саобраћаја, а тиме и загађености ваздуха рад код куће може бити позитиван и са становишта послодавца у смислу уштеде у простору или повеһања продуктивности.

\section{2. Правци дневних миграција}

Дневне миграције становништва одликују промене у обиму, правцима и демографским и социоекономским карактеристикама миграната. Ове трансформације резултат су промена у обиму активног становништва, систему образовања, промена на тржишту рада, промена у доступности и развијености саобраһајне мреже, у карактеристикама урбане структуре, као и промена личних аспирација и животних стилова радника током времена. Трансфер становништва који се раније одвијао из пољопривредних у непољопривредне делатности данас се одвија у смеру индустријске делатности - услужне делатности, тј. одвија се трансформација структуре економије из доминације производње у експанзију услужних делатности. Наведене промене одражавају се на правце дневних миграција у свету и у нашој земљи (уз додатне ефекте ослабљене индустрије и привредних реформи). Поред повећања удела радника који раде део радног времена код куће, у свету постоји тренд ка разноврснијим путањама дневних миграција и повећању удела дневних миграција на дуже дистанце у укупном броју свакодневних путовања. На то утичу не само промене на тржишту рада већ и развој саобраћаја и саобраћајних средстава. Праћење тенденција у токовима дневних миграција у нашој земљи доприноси сазнањима значајним за потребе планирања локалног и регионалног развоја.

Дневне миграције активног становништва Централне Србије и Војводине, од 60тих година двадесетог века, најинтензивније се одвијају у оквиру општине (локалне). Удео међурепубличких дневних миграција у укупним дневним миграцијама активног становништва се непрестано смањује. Овај процес је највише изражен на територији Војводине, чије је становништво учествовало са $13 \%$ у међурепубличким дневним миграцијама 1961. године, да би 2002. године ове дневне миграције биле готово занемарљиве. То је последица смањења броја радника који су за време бивше СФРЈ свакодневно путовали на посао у суседну Републику Хрватску. Две трећине дневних миграната у Централној Србији и Војводини 2002. године свакодневно је путовало на 
посао у друго насеље исте општине, док је једна трећина путовала на радно место у другу општину. У периоду 1961 - 2002. година променила се и структура дневних миграната према полу у погледу територијалног домета миграције. Шездесетих година прошлог века запослене жене у Србији су више од мушкараца путовале на посао у границама исте општине. То је нарочито било изражено у Војводини. У погледу територијалног домета дневне миграције жена у односу на мушкарце 2002. године на подручју Централне Србије разлика готово да више није било, док су у Војводини ове разлике и даље биле приметне мада у мањој мери (Лукић В.,2006). Више од $50 \%$ женског становништва у структури међуопштинских дневних миграционих токова 2002. године имала је само општина Чачак $(52,7 \%)$. У структури економски активних жена које учествују у дневним миграцијама општина Савски Венац, Нови Београд, Лапово, Нишка Бања и Сремски Карловци више од $90 \%$ жена радило је ван своје општине становања. Најмање могућности за запослење женске радне снаге имају општине Нишка Бања и Гроцка са $64,4 \%$ односно $61,4 \%$ женског активног становништва које свакодневно путује до места рада у другу општину (Лукић В.,2007).

Табела 6. Дневне миграције радника према територијалном домету

\begin{tabular}{|c|c|c|c|c|}
\hline Територија & Укупно & Локалне & Mebууопштинске & Meb)ypeny6личке \\
\hline \multicolumn{5}{|c|}{ Аневни мигранти 1961. године } \\
\hline Централна Србија & 176.402 & $59,5 \%$ & $37,0 \%$ & $3,3 \%$ \\
\hline Војводина & 51.235 & $51,8 \%$ & $35,0 \%$ & $12,8 \%$ \\
\hline \multicolumn{5}{|c|}{ Аневни мигранти 1981. године } \\
\hline Централна Србија & 370.105 & $73,4 \%$ & $25,3 \%$ & $1,0 \%$ \\
\hline Војводина & 139.739 & $47,1 \%$ & $27,1 \%$ & $9,4 \%$ \\
\hline \multicolumn{5}{|c|}{ Аневни мигранти 2002. године } \\
\hline Централна Србија & 405.192 & $62,4 \%$ & $34,3 \%$ & $0,5 \%$ \\
\hline Војводина & 159.862 & $64,6 \%$ & $34,6 \%$ & $0,1 \%$ \\
\hline Србија (без Ким) & 565.054 & $63,0 \%$ & $34,4 \%$ & $0,4 \%$ \\
\hline
\end{tabular}

Извор података: С3С, 1967; Rоса O.,1986; Р3С, 2004.

У суседној Хрватској је најизраженија међуопштинска мобилност активног становништва. У другом насељу исте општине ради $30,1 \%$, у другој општини исте жупаније (облик територијално-административног организовања више општина) $50 \%$ и у другој жупанији $19,6 \%$ радника. Жене више путују на краћим раздаљинама. У структури дневних миграната који раде у другој општини $60,7 \%$ чине мушкарци, а $39,3 \%$ жене (www.dzs.hr). Већи обим дневних миграција унутар жупанија од локалних показатељ је хомогеније урбане мреже у односу на Србију. У Италији пример групе градова јужно од Рима показује да у својој општини ради $67 \%$ мушкараца и $74 \%$ жена дневних миграната (Cristaldi F.,2005).

У деветнаест општина у Србији 2002. године више од $40 \%$ радника радило је ван општине становања, док је у највећем броју општина (117) ван општине становања радило до $10 \%$ радника. Најизраженију међуопштинску дневну мобилност активног становништва 2002. године имале су општине Сремски Карловци, Нишка Бања и Дољевац које се граниче са макрорегионалним центрима (Нови Сад и Ниш), као и београдске општине ван насеља Београд: Барајево, Гроцка и Сопот. Међуопштинске дневне миграције активног становништва које обавља занимање 2002. године биле су најизраженије у Нишкој Бањи. Преко 63\% укупног активног становништва ове општине свакодневно је путовало до места рада у другу општину. Општина Нишка Бања формирана је 2000. године издвајањем групе насеља из сасатава општине Ниш. Општина Сремски Карловци, у зависности од године пописа становништва, се третира као део општине Нови Сад или као самостална општина. Општине Нишка Бања и Сремски Карловци, са $63 \%$ односно $58 \%$ активног становништва које ради ван општине становања, потврда су да токови дневних миграција становништва показују стварне 
функционалне границе општина у односу на формално-правне административнотериторијалне границе (Лукић В., 2006). Према Илићу највише дневних миграната 1961. године било је из насеља у околини великих градова као што су Београд, Ниш, Нови Сад (Ilić J.,1970). Подаци о међуопштинској дневној мобилности активног становништва 2002. године показују да у Србији урбани центри Београд, Нови Сад и Ниш имају најјаче гравитационо дејство и почетком 21. века. Правци кретања дневних миграната упућују на изражену економску атрактивност ових центара за дневне мигранте. Развојем саобраћаја и саобраћајних средстава у Србији (нпр. очекивана изградња аутопута Београд - Пожега), чиме ће се смањити време потребно за путовање, може се очекивати још већа међуопштинска дневна мобилност радника и флексибилност у погледу односа места рада и места становања. На то Һе утицати и промене везане за функционисање тржишта рада и структуру домаћинстава.

Веома је значајно и стално (непрестано) праһење и истраживање праваца токова дневних миграција према хијерахијском рангу насеља становања и рада у мрежи насеља. Дневне мигранте који долазе на посао из насеља мањег ранга претежно примају насеља која припадају вишем хијерархијском рангу у мрежи насеља. Најчешһе се свакодневно путује од места становања до места школовања/рада из сеоског у градско насељье - центар истоимене општине. Ове миграције сеоског становништва представљају значајан облик економске и друштвене везе између сеоских и градских насеља. Значај сагледавања дневне просторне мобилности руралне популације за концепцију ревитализације села у Србији истиче Стаменковић (Стаменковић C., 1989;1996).

Дневне миграције радне снаге на подручју бивше Југославије у периоду након 1950. године одвијале су се претежно из пренасељених сеоских насеља, на око $50 \mathrm{~km}$ удаљености од неког важнијег индустријског средишта, до градова са одређеном концентрацијом радних места (Zuljić S., 1970). Дневних путовања градског становништва, које је до свог радног места прелазило дуже релације, највише је било на подручју Централне Србије, док су најређа била у Војводини с обзиром на популационо релативно велика насеља Војводине (CDI-IDN, 1971). У Војводини је 2002. године 70\% дневних миграната било из сеоских насеља, односно $77 \%$ у Централној Србији. Удео дневних миграната из сеоских насеља у другим земљама је претежно мањи него код нас, нпр. у Летонији и Литванији између 1/6 и 1/3 дневних миграната путује из сеоских насеља (Hazans M.,2004). Највећи број жена које раде ван свог места становања живи у насељима која нису градска по типу, иако је у последњој деценији 20.-тог века изражен тренд укључивања у дневне миграције све већег броја економски активних жена и у градским насељима.

Табела 7. Структура дневних миграната у Србији према типу насеља становања (\%)

\begin{tabular}{|c|c|c|c|}
\hline Tип насеља & 1981 & 1991 & 2002 \\
\hline \multicolumn{4}{|c|}{ Централна Србија } \\
\hline Градска & 15,5 & 20,6 & 23,2 \\
\hline Oстала & 84,5 & 79,6 & 76,8 \\
\hline \multicolumn{4}{|c|}{ Војводина } \\
\hline Градска & 40,4 & 28,0 & 29,8 \\
\hline Oстала & 59,6 & 72,0 & 70,2 \\
\hline
\end{tabular}

Извор података: Р3С,2006а; Р3С,2004.

Приметно је постепено повећање интензитета дневних миграција становништва са местом становања у градским насељима. Реч је од дневним мигрантима који претежно раде/школују се у другој општини. Постојање токова дневне миграције активног становништва између градова указује на разлике у величини контингента 
радне снаге, броју радних места и квантитативној и квалитативној потражњи за радном снагом, као и степену развијености и диверзификованости привреде.

Дневне миграције као облик просторне покретљивости становништва 1961. године нарочито су биле заступљене код становништва популационо малих насеља (испод хиљаду становника). Више од половине од укупног броја радника ових насеља били су дневни мигранти, док је у насељима популационе величине $1.000-10.000$ становника једна трећина радника учествовала у дневним миграцијама (CDI-IDN, 1971). И 2002, године око једне трећине радника $(34 \%)$ у насељима популационе величине 1.000 - 10.000 становника учествовало је у дневним миграцијама (Р3С,2004a).

Већи степен хијерархије у оквиру урбаних система генерално је повезан са већим обимом конвергентних дневних миграција. Хагерстранд истиче да су миграције уско везане за урбану хијерархију. Удаљеност од главних урбаних центара један је од најважнијих фактора утицаја на миграцију, и подручја у близини или са лакшим прилазом - доступношћу градовима дају веһину миграната овим градовима. Генерално што је подручје изолованије мање су развијене путање миграција. У близини главних градова миграциона транзиција биће разложена до најнижих нивоа у хијерархији насеља, док Һе у даљим подручјима од главног града бити развијена само кретања из већих градова, док ће већина кретања из других нивоа хијерархије бити локална (Hagerstrand 1957, према Roseman C.,1971).

До појаве дневних миграција између нивоа урбаног система доводе бројни фактори. Један је жеља за животом у другом нивоу хијерархије у односу на онај у коме је радник запослен (било да је реч о могућностима које тај ниво урбане хијерархије пружа или присуству родбине, пријатеља). У том случају радник је вољан да поднесе трошкове дневне миграције, укључујући и време потребно (утрошено) на свакодневно путовање. Други фактор је чињеница да појединац запослен у одређеном нивоу хијерархије не може да приушти трошкове живота у том нивоу али може у другом нивоу, заједно са трошковима дневне миграције. Трећи фактор укључује могуће погодности изведене из физичке раздвојености места рада и места становања (Parr J.В.,1987). Гравитационо подручје радника већих градова, а нарочито главног града земље може се простирати и на више десетина километара. Чак око $17 \%$ дневних миграната Мађарске путовало је на посао у Будимпешту 1984. године. Гравитационо подручје тог града обухватало је готово целу територију Мађарске (Bohm,1984 према Roca O., 1986). Око 15\% свих запослених главних градова Естоније, Летоније и Литваније чине дневни мигранти из других општина (Hazans M.,2004). И у другим земљама је запажено да је вероватноһа дневне миграције веһа од просека уколико је пребивалиште дневног мигранта у близини главних градова региона. Најдоминантнији правци дневне миграције у Шпанији и Италији су из региона који окружују главни град провинције или округа ка самим главним градовима (Artis M., J.Romani, J.Surinach,2000; Cristaldi F.,2005). Дневне миграције из неметрополитанских подручја у метрополе (extended metropolitan commuting), од стране истраживача који се баве теоријама центара раста, означавају се као најважнији појединачни механизам где се импулси раста преносе из великих регионалних центара раста у околне градове и сеоска подручја (Berry, 1977, према Taaffe E., H.Gauthier, T.Maraffa, 1980). Има сазнања да мали градови у близини метропола имају значајну улогу у смањењу дневне миграције из неметрополитанских подручја у метрополе на удаљеностима између 25 и 35 миља (Taaffe E., H.Gauthier, T.Maraffa,1980).

Путање дневних миграција везане су за ограничења и могућности у погледу места становања и места рада, те се током времена могу мењати и главни правци дневних миграција одређеног подручја. Праћење ових промена има свој практичан значај за локално и регионално планирање и имплементацију програма развоја. У САД 
и многим западноевропским земљама запажен је од 80-их година прошлог века тренд дневних миграција смера предграђе-центар града. У литератури су заступљене две хипотезе о могућим детерминантама промене смера дневних миграција. Неколико аутора сугерише да структурно-економске промене на локалном и регионалном нивоу утичу на путање токова дневних миграција. Према овом становишту промене у функционалној структури одређених локација узрокују разлике у оријентацији праваца дневних миграција, у зависности од економске структуре и степена образовања активног становништва. То су примери хипотезе регионалног преструктуирања, према којој се региони развијају као одговор на фундаменталне промене у организацији производње, на путу ка сервисно и информационо заснованој економији (Clark W.A:, M. Kuijperslinde,1994). Модернизација економске структуре, као резултат преласка са производње на доминацију скетора услуга, а нарочито развоја информационе технологије, уз растућу доминацију међународних компанија доводи до промена у просторној дистрибуцији могућности за запослење. Тако долази до дисперзнијих путања дневне миграције (Van der Laan L.,1998). Ова хипотеза је у супротности са хипотезом деконцентрације према којој су урбане промене проузроковане развојем саобраћаја и комуникација, порастом прихода и променама у избору места становања радника. На деконцентрацију популације утиче све већа мобилност радника и предузећа, али и избор ређе насељених и мање загађених подручја за породични живот. Ренков и Хувер подржавају хипотезу деконцентрације према којој “доминантан утицај на путање дневних миграција и територијални размештај становништва у току последње две деценије је имала ексурбанизација везана за промене у преференцијама места становања" (Renkow M.,D.Hoover, 2000). Поменуте опречне хипотезе о разлозима промене смера дневних миграција становништва довеле су до дебате да ли су промене у урбаној просторној структури, као што је полицентричност, резултат демографске деконцентрације или производног преструктуирања, истичући да су дневне миграције радника детерминанта еволуције урбане просторне структуре (Wheller J., 1967).

Паралелно са променом смера дневних миграција у САД и развијеним западноевропским земљама забележен је пораст броја становника приградских насеља, што је утицало на бројне анализе о могућој вези између ових појава. Анализа повезаности између места пребивалишта, дневних миграција и дефинитивних миграција показала је везу између повећаног обима дневних миграција ка градовима и пораста броја становника приградских насеља. Видљиве су три различите везе између обима дневних миграција и промена у обиму популације Подручја у близини метропола или унутрашњих центара раста имају позитивну корелацију између дневне миграције и популационог раста. Подручја најдаље од економских могуһности које ови центри обезбеђују имају мали обим дневних миграција и изражену емиграцију. Подручја једнако удаљена од метро центара и унутрашњих центара раста показују комбинацију претходне две везе дневних миграција и промене броја становника указујући да су дневне миграције увод у емиграцију (Wheeler,1971; Fisher J., R.Mitchelson, 1981). Ренков и Хувер утврдили су статистички значајну позитивну везу између досељавања на село и дневних миграција у градове из округа лоцираних у оквиру 35 миља (56,3 $\mathrm{km})$. Када је реч о сеоским насељима и градовима који су удаљенији од 35 миља није утврђена никаква веза популационих промена са дневним миграцијама, што је у складу са налазима других истраживача (Renkow M., D.Hoover, 2000).

У нашој земљи још увек је у урбаним центрима изражена концентрација како популације, тако и активности. Управо зато и токови дневних миграција имају доминантан смер село-град. Промене праваца дневних миграција реално се могу очекивати у будућности и на нашим просторима, па ће се самим тим јавити и потреба за праћењем и истраживањем овог процеса и његових узрока и последица у Србији. 


\section{3. Структурна обележја дневних миграната}

Демографска и социоекономска обележја дневних миграната разликују се у зависности од подручја на којима се одвијају. Када је реч о полној структури дневних миграната у већини земаља је приметно веће учешће мушкараца. У дневним миграцијама у Србији такође више учествују мушкарци (65\%) од жена (35\%). У Србији ce учешће жена у дневним миграцијама постепено повећава пратећи све више образовање жена и процес повећања учешћа жена у укупном активном становништву које обавља занимање. У структури дневних миграната према полу приметно је повећање учешћа жена са $7,8 \%$ 1961. године на $34,3 \%$ 2002. године у Централној Србији, односно са 6,8\% на 36,7\% у Војводини (С3С, 1967; Р3С, 2004). Још 1950. године у CP Немачкој 21,6\% дневних миграната било је женског пола (Dickinson R.E., 1959 према Roca O., 1986). Према Попису становништва из 2001. године у структури активних дневних миграната у Хрватској мушкарци су чинили $60 \%$ а жене $40 \%$ (www.dzs.hr). У САД жене више учествују у дневним миграцијама у односу на европске земље. У Сан Дијегу нпр. анкета за потребе пројекта смањења саобраћајног загушења је показала да су дневни мигранти 55\% мушкарци и 45\% жене (Wilbur Smith Associates, 1996). У профилу запосленог дневног мигранта у већини земаља OECD-а разлике према полу су јасно изражене. Само у Француској, жене више учествују од мушкараца у дневној миграцији. Када је реч о образовној структури дневних миграната, у западноевропским земаљама преовладавају високообразовани у Великој Британији и Немачкој, док у Француској и Италији већина дневних миграната има основно образовање, а у Аустрији средње образовање. Оваква структура дневних миграната према образовању може делимично одражавати различите форме урбаног развоја богатије групе становништва у неким земљама напуштају градске средине, живе у предграђима и путују до центра на посао (OECD,2005). Структура дневних миграната према образовању није доступна из објављених података Пописа становништва у Србији. Ово обележје може се пратити само на основу проучавања дневних миграција на одређеним подручјима, помоћу анкетних истраживања или путем посебне обраде података пописа становништва, што ограничава простор истраживања и не пружа могућности за праћење варијабилности овог обележја мобилне радне снаге у Србији током времена.

Секундарни сектор је сектор делатности са константно највећим обимом токова дневних миграција у Србији у последњих четрдесет година. Године. 1961. у дневним миграцијама у Србији највише су учествовали радници запослени у индустрији, рударству и грађевинарству. У Централној Србији, од укупног броја запослених ван места сталног боравка 1961. године, $6,6 \%$ радника било је запослено у примарним делатностима, $59,5 \%$ у секундарним, $22 \%$ у терцијарним делатностима, и $10,7 \%$ у Квартарним делатностима. У Војводини је, исте године, од укупног броја дневних миграната било 13,1\% запослених у примарним делатностима, 48,6\% у секундарним, $24,9 \%$ у терцијарним и $10,9 \%$ у квартарним делатностима (С 3 , 1967$)$. И у другим земљама у овом периоду преовладавали су дневни мигранти запослени у индустрији. Преко половине дневних миграната у САД 70-их година прошлог века радило је у индустрији и грађевинарству, а остали дневни мигранти радили су у услужним делатностима (Holmes J.,1971). Већина дневних миграната шездесетих година прошлог века у Русији и Мађарској су били млади мушкарци, неквалификовани или полуквалификовани, највише запослени у индустрији. Од седамдесетих година у Мађарској долази до промена у био-социјалној структури дневних миграната, те дневни мигранти више нису долазили из редова сељака, већ су то били новозапослени млади људи. Долази и до повећања запослености жена, па се у саставу дневних 
мигранта повећава број жена, стручњака, образованијих и квалификованијих радника, а повећао се и удео других сектора економске делатности осим индустрије (Bohm, 1984 према Roca O., 1986). На простору бивше Југославије промене у структури дневних миграната одвијале су се нешто спорије. Истраживања у Загребу показала су преокрет у квалификационој структури радника дневних миграната од осамдесетих година. У већини општина преовладавали су квалификовани и ВКВ радници (Vresk M.,1984). Трансформације у структури привреде Србије одражавају се на структуру дневних миграната према економској делатности. Тако се и у Србији, аналогно процесу који је већ узео маха у развијенијим земаљама, запажа постепено смањење удела дневних миграната запослених у примарним и секундарним делатностима, уз пораст учешћа дневних миграната запослених у терцијарним и квартарним делатностима, што је у складу са променама у структури укупног активног становништва према делатности. У Централној Србији, од укупног броја запослених ван места сталног боравка 2002. године, $3,7 \%$ радника било је запослено у примарним делатностима, $50 \%$ у секундарним, $27,6 \%$ у терцијарним делатностима, и $16,1 \%$ у квартарним делатностима. У Војводини је, исте године, од укупног броја дневних миграната било 7,3\% запослених у примарним делатностима, $45,5 \%$ у секундарним, $27,3 \%$ у терцијарним и $17,7 \%$ у квартарним делатностима. Највећи број дневних миграната 2002. године био је запослен у прерађивачкој индустрији (Р3С, 2004).

Табела 8. Дневне миграције радника

према сектору економске делатности и полу 2002. године (\%)

\begin{tabular}{|l|c|c|c|c|}
\hline \multicolumn{1}{|c|}{ Територија } & Примарне & Секундарне & Терцијарне & Квартарне \\
\hline \multicolumn{5}{|c|}{ Мушкарци } \\
\hline Централна Србија & 6,7 & 55,8 & 26,6 & 10,9 \\
\hline Војводина & 11,3 & 50,9 & 26,5 & 11,3 \\
\hline \multicolumn{5}{|c|}{ Жене } \\
\hline Централна Србија & 5,4 & 38,9 & 29,6 & 26,1 \\
\hline Војводина & 6,3 & 36,2 & 28,8 & 28,7 \\
\hline
\end{tabular}

Структура дневних митраната утиче и на правце дневних миграција. Полазећи од претпоставке да жене, образованији и радници у одређеним делатностима свакодневно мигрирају "на горе" у хијерархији насеља, због таквог размештаја радних места жена и потреба метро центара за одређеним делатностима, истраживање токова дневних миграција у оквиру мреже насеља у САД показала су да жене, радници са већим степеном образовања као и запослени у производним делатностима и они који имају веће приходе свакодневно путују "на горе" у хијерархији, готово два пута више од оних који путују у мање насеље (Fuguitt G.V., 1991). Ван дер Лан на примеру Холандије показује да што се дневне миграције одвијају на краћим удаљеностима удео жена се повећава, али се удео млађих и образованијих радника смањује (Van der Laan L., 1998).

Након анализе обима, развоја и основних карактеристика процеса дневних миграција у Србији и свету, у наредном поглављу биће разматране детерминанте обима, структуре и праваца токова дневних миграција активног становништва и школске и студентске омладине на примеру дневног урбаног система Панчева, који је и главна тема овог рада. 


\section{III ДЕТЕРМИНАНТЕ ОБИМА, СТРУКТУРЕ И ПРАВАЦА ТОКОВА ДНЕВНИХ МИГРАЩИЈА АКТИВНОГ СТАНОВНИШТВА И ІІКОЛСКЕ И СТУДЕНТСКЕ ОМЛАДИНЕ ДНЕВНОГ УРБАНОГ СИСТЕМА ПАНЧЕВА}

На развој Панчева, као и на већину других насеља, утицала је спрега reографских и друштвено-историјских услова. Услове за развој дневних миграција, поред rеосаобраћајног положаја, одредили су и демографски потенцијали насеља полазишта и одредишта дневних миграција, карактеристике мреже насеља, број и диверзитет функција, а нарочито структура и достигнути степен развоја привреде. Сви ови фактори одражавају се на обим, правце и структуру токова дневних миграција Панчева, указујући на постојање међузависности процеса дневних миграција и демографских, саобраћајних и друштвено-економских фактора.

\section{1. Гео-саобраһајни и друштвено-економски положај Панчева као детерминанте обима и територијалног домета дневних миграција}

Геосаобраћајни положај Панчева један је од битних фактора који условљава и утиче на формирање, обим и територијални домет конвергентних и дивергентних дневних миграција становништва, које се на овом подручју одвијају као резултат деловања функција насеља и показатељ зоне њиховог функционалног деловања. Територија општине Панчево простире се у правцу северозапад - југоисток и граничи се са општинама Опово, Ковачица и Алибунар на северу и североистоку, и општином Ковин на истоку. Јужну и западну границу Општине чини река Дунав са београдским општинама Палилула и Гроцка на другој обали. У односу на веће макрорегионалне центре Панчево је лоцирано $21 \mathrm{~km}$ североисточно од Београда и $97 \mathrm{~km}$ југоисточно од Новог Сада. Саобраћајна удаљеност Панчева од суседних општинских центара $(\mathrm{y} \mathrm{km})$ износи 33 за Алибунар, 31 за Ковин, 26 за Опово и 29 за Ковачицу. Добра саобраћајна повезаност Панчева стимулише развој дневних миграција на овом простору

Повољна локација Панчева детерминисана је како локалним, тако и регионалним факторима: микрорељефним приликама, положајем у односу на Београд и рангом Београда у функционалној структури урбаних центара Србије. Веома је битан повољан положај Панчева у односу на саобраһајнице - друмске, железничке и водене путне правце, имајући у виду да путовање дневног миграната зависи између осталог и од доступности саобраћајне мреже.

Смештен у крајњем југозападном делу Баната простор који обухвата општина Панчево има специфичан регионални положај на контакту региона различитих природних потенцијала (Војводине и Централне Србије). Положај на контакту ова два reопростора, која се разликују по особеностима рељефа али и производној оријентацији, битан је фактор утицаја на развој и обим дневних миграција овог простора. Још шездесетих година двадесетог века велики број сељака из Винче, Ритопека и Вишњице прелазио је Дунав чамцима и скелама, и у Панчево и друга јужнобанатска места довозио разно воће на пијаце. Банатски сељаци долазили су у крајеве јужно од Дунава ради продаје жита и живине (Илић Ј.,1967).

Друга повољност геосаобраһајног положаја Панчева и детерминанта обима и територијалног домета дневних миграција Панчева, огледа се у непосредној близини београдске агломерације као средишта бројних и разноврсних функција, саобраһајног чворишта и привредног и културно-образовног центра у земљи. Панчево има функцију вратница Баната према Београду (Илић Ј., 1971). Још у Краљевини Југославији Панчево је било у посебној административној јединици заједно са Земуном и Београдом. Повољан положај Панчева у односу на Београд ублажава периферност положаја 
Панчева у урбаној мрежи Војводине. Функционална снага Београда испољава се кроз концентрацију становништва и активности - промета и производње. Близина Београда и добре саобраћајне везе утицале су да се Панчево нађе у склопу београдског метрополитенског подручја, формираног на простору средњег Подунавља на правцу Нови Сад - Београд - Панчево - Смедерево. У београдско - панчевачком Подунављу спајају се посавска, сремска, колубарска и банатска осовина развоја (Тошић Б., Матијевић Д., Лукић В., 2004). Ранг Београда у функционалној структури урбаних центара Србије и територијална и функционална коресподентност Београда и Панчева резултира снажним дивергентним дневним миграцијама активног становништва и школске и студентске омладине из Панчева према Београду.

Могућност одвијања различитих видова саобраһаја још једна је од повољности положаја Панчева. Саобраћајнице представљају дугорочно делујући фактор који усмерава правце кретања и развојне процесе у позитивном и негативном погледу (Krešić, 1981. према Томић, Ромелић, 2003). Саобраһајнице утичу на обим и усмереност токова дневних миграција, с обзиром да дневни мигранти теже што нижим трошковима транспорта и веһој саобраһајној доступности. Повољан географски положај простора Општине омогућава одвијање друмског, железничког и воденог (данас претежно теретног) саобраћаја уз врло интензиван промет робе и путника. Заступљен је и међународни транзитни саобраћај путника и робе на путу за Румунију. Могућност коришћења сва три типа саобраћаја, осим за становништво, веома је значајна и за привреду Панчева.

Избор одређеног вида саобраћаја утиче на различито време потребно за свакодневно путовање дневних миграната. У односу на остале видове саобраћаја друмски саобраћај има доминантну улогу на простору општине Панчево. Друмске саобраһајнице везане су за београдски саобраћајни чвор као највећу раскрсницу путева међународног значаја у окружењу. Густина саобраћајне мреже у односу на Војводину релативно је ниска. Путна мрежа у Панчеву ређа је него у осталом делу Баната (површина општине Панчево чини 7,7\% површине Баната, док дужина путева кроз Општину износи $6,3 \%$ свих путева у Банату). Укупна дужина путева на простору Општине 2003. године износила је $147 \mathrm{~km}$ (магистрални $58 \mathrm{~km}$, регионални $16 \mathrm{~km}$ и локални путеви у дужини од $73 \mathrm{~km}$ ). Од тога су $143 \mathrm{~km}$ са савременим коловозом. Од значајнијих друмских саобраћајница, преко територије Општине пролазе пут међународног значаја Е-70 (Београд-Панчево-Вршац-Темишвар) и магистрални пут М24 (Кикинда-Зрењанин-Панчево-Ковин-Смедерево-Пожаревац). То су напрометније друмске саобраћајнице у Банату. Саобраћајницом Е-70 у току дана саобраћа 12.564 возила, односно 523 возила на сат, док магистралним путем М-24 саобраћа 5.979 возила на дан, односно 249 возила на сат, са најфреквентнијим делом на релацији ПанчевоКовин (Р3С,2003a). Употреба аутомобила на простору Општине је у порасту. Број регистрованих путничких возила у општини Панчево 2002. године износио је 25.707 (чак $45 \%$ возила Јужно-банатског округа) или 5 становника на један аутомобил (Р3С,2003a). И 1964. године општина Панчево имала је највише моторних возила (764 путничка аутомобила) у Јужном Банату (Илић Ј.,1967), што је последица јаче економске развијености ове Општине и њеног бољег саобраћајно-географског положаја у односу на Београд у поређењу са другим банатским општинама. 


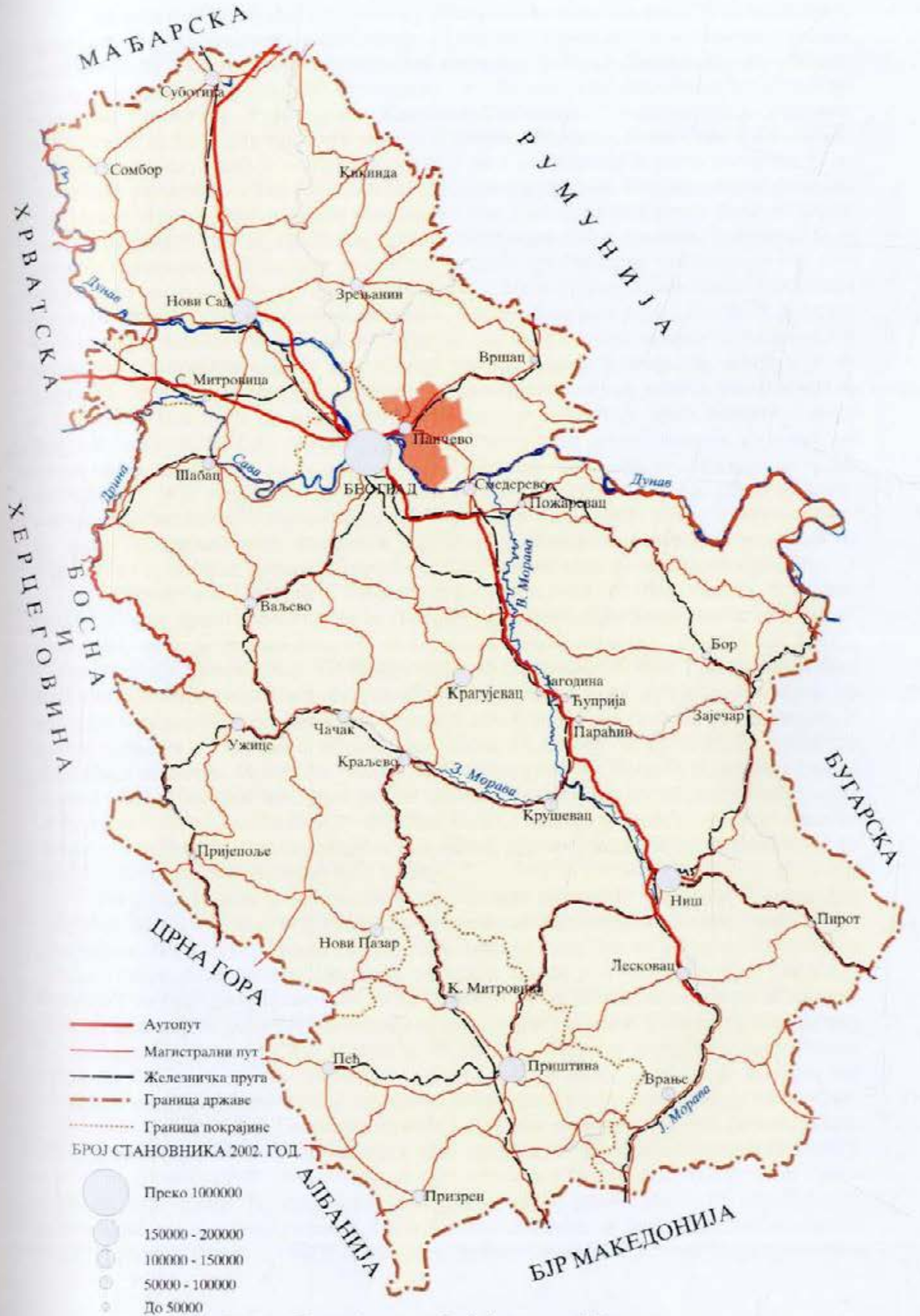

Карта 4. Географски и саобраћајни полюжај Панчева 
Железнички саобраћај на простору општине Панчево све више губи на значају, осим када је реч о транзитном саобраһају. Преко територије општине Панчево пролазе железничке пруге које имају међународни карактер: Београд-Панчево-Вршац-граница према Румунији (Моравица)-Темишвар, и Београд-Панчево-Зрењанин-Кикиндагранични прелаз са Румунијом (Жомбоља)-Темишвар. У панчевачкој општини железницом су повезана само три насеља (Панчево, Банатско Ново Село и Качарево). Већина пруга изграђена је до Другог светског рата и технички је доста застарела те не омогућава развијање већих брзина и не одговара савременим стандардима носивости. Још шездесетих година прошлог века готово све јужнобанатске пруге биле су лошег квалитета, пошто им је приликом градње била намењена локална функција. Број путника корисника железничког саобраһаја на простору Општине смањивао се још у то време због све јаче улоге аутобуског саобраћаја. Мале брзине железничког саобраћаја узрокују већи утрошак времена на путовање. Панчевцима који раде у Београду, а путују возом као превозним средством, потребно је око 40 додатних минута за одлажење и долажење до станице, јер су оне обично на периферији насеља. За аутобус је то додатних 30 минута, имајући у виду удаљеност станице од центра насеља (Илић J.,1967). Као још један од недостатака железничког саобраћаја треба навести и мали број полазака, мањи број и веһу удаљеност станица од центра насеља у односу на аутобуске и чињеницу да је железнички саобраћај нередован и одликују га честа кашњења, те је је овај вид саобраћаја самим тим и непоуздан. Када је реч о дневним миграцијама активног становништва, али и ученика и студената веома је важно стићи на време до посла/школе, те овакви услови у железничком саобраћају утичу да се највећи део путничког промета на простору Општине обавља друмским саобраһајем.

Са Београдом Панчево је повезано аутобуском линијом 1946. године. Beh 1966. године било је преко сто полазака из Панчева за Београд само панчевачког аутобуског предузећа, тако да је саобраћај на овој релацији имао карактер градског саобраћаја (Универзитет у Новом Саду, ПМФ-Институт за географију, 1996). Ред вожње и број полазака аутобуса релативно су усклађени са активностима путника. Аутобуси на релацији Београд-Панчево саобраћају радним даном у интервалима од по 30 минута. У време одлазака и долазака радника са посла (4.30-8.00 и 12.30-16.00) аутобуси саобраһају на сваких 15 минута. Чешһе саобраһање аутобуса било би пожељно и нешто након 16.00 часова због све дужег радног времена запослених. Аутобуским саобраћајем са центром Општине најслабије су повезана насеља Глогоњ и Иваново са девет односно тринаест аутобуских полазака дневно, док већина других насеља Општине има више од двадесет аутобуских полазака у току дана.

Од 1992. године бољем повезивању Панчева са широм околином и Београдом допринео је Беовоз као вид приградског железничког превоза. Беовоз саобраћа на релацијама Панчево Војловица-Земун-Нова Пазова-Стара Пазова и Панчево Војловица -Ресник-Рипањ-Младеновац. Просечан интервал возова је 45-90 минута, а у периоду најгушћег саобраћаја (у време долазака и одлазака са посла) интервали су на 30 минута. Постоје индиције о укључењу Беовоза у систем јавног градског превоза и у том случају би маркице за превоз ГСБ-а важиле и за Беовоз. Међутим имајући у виду велики просечан интервал између саобраћања возова претпоставка је да би се и поред ове олакшице већина путника и даље превозила аутобуским саобраћајем иако је он скупљи.

Положај општине Панчево у приобаљу Дунава и близина других речних токова погодују одвијању воденог саобраһаја и чине предност географског положаја Панчева у односу на друге градове Баната. Водени путни правци у Панчеву обухватају реке Дунав и Тамиш, при чему је Тамиш плован само једним малим делом. Током 19. века Панчево је било јако извозно пристаниште. Паробродски саобраћај за Београд и Земун отворен је 1850. године (Илић Ј.,1967). Данас се у Панчеву претежно одвија бродско-теретни 
речни саобраћај. Лука "Дунав- Панчево" обавља послове претовара и складиштења свих врста робе у унутрашњем и међународном промету, као и превоз у друмском саобраћају. Положај Панчева у средњем Подунављу, на европском Дунавском коридору бр. VII у наредном периоду може добити већем на значају. Према регионалном просторном плану административног подручја града Београда планирано је редефинисање улоге Луке "Панчево" у односу на Луку "Београд" и њихово повезивање у систем мултимодалног чвора уз специјализацију понуде услуга и функција (Урбанистички Завод Београда, 2002). Иако је речни саобраћај практично безначајан за превоз путника, а самим тим и за обим и правце дневних миграција повезивање ове две луке било би веома значајно за даљи развој панчевачке привреде. На токове дневних миграција битније би се одразило евентуално организовање јавног превоза реком, због проблема у друмском саобраћају и гужви на панчевачком мосту.

Постојање саобраћајне везе између два насеља услов је за одвијање дневних миграција. Положај појединачних насеља у односу на саобраћајнице и развијеност саобраћајне мреже (могућности које саобраћајни положај насеља пружа за коришћење одређене врсте превозног средства) значајни су фактори обима и праваца дневних миграција на простору општине Панчево. Развијеност саобраћајне инфраструктуре олакшава или отежава одвијање дневних миграција становништва делујући на различито време потребно за свакодневно путовање. Саобраћајна мрежа је различито развијена у насељима Општине и нека насеља су боље, а нека лошије саобраћајно повезана са општинским центром и околином. Удаљеност насеља Општине од градског центра износи: Панчево - Банатско Ново Село $17 \mathrm{~km}$, Панчево - Долово $21 \mathrm{~km}$, Панчево - Старчево $9 \mathrm{~km}$, Панчево - Омољица $16 \mathrm{~km}$, Панчево - Банатски Брестовац $22 \mathrm{~km}$, Панчево - Качарево 9 km, Панчево - Јабука 11 km, Панчево - Глогоњ 19 km и Панчево Иваново $21 \mathrm{~km}$. Од свих насеља општине Панчево најлошије саобраћајно повезано са околином је Иваново, које је од општинског центра удаљено $21 \mathrm{~km}$, има изолован положај и са околином је повезано само преко пута према Омољици. Развој и унапрећивање саобраћајне мреже значајни су не само ради повезивања делова Општине који нису довољно добро саобраһајно повезани, веһ и ради одржавања дневних миграција радне снаге као мере демографске ревитализације сеоских насеља.

Поред геосаобраћајног положаја, на развој општине Панчево утицао је и политичко-економски положај овог простора, који се мењао (погоршавао или унапређивао) у зависности од промене влада и померања државних граница. Општина Панчево налази се на простору преплитања географских, демографских, економских, и културних утицаја Београда (Централне Србије) и Баната (Војводине), и чини један од елемената њихове просторне и функционалне повезаности. Аустроугарска граница која је све до 1918. године ишла долином Саве и Дунава спречавала је сваку гравитацију области северно од Београда. На карти из доба Аустроугарске види се да највећи део данашњих саобраћајних линија јужно и северно од Саве и Дунава тада није постојао, као што није било ни моста преко Дунава код Панчева (Савић О., 1962). У то време Панчево је било у гравитационој сфери Будимпеште и Темишвара. Улазак Баната у састав Краљевине Србије а затим Краљевине Срба Хрвата и Словенаца и промена државних граница утицали су да до пуног изражаја дође повољност геосаобраћајног положаја Панчева у близини Београда. Од тада Панчево улази у гравитациону сферу Београда, а што је нарочито изражено након 1935. године када је успостављена железничка и друмска веза са Београдом изградњом панчевачког моста преко Дунава. 


\section{2. Популациона динамика и промене у просторном размештају становништва као детерминанте обима и територијалног домета дневних миграција}

Повољни услови за живот, првенствено за бављење пољопривредом, ловом и риболовом, условили су насељеност подручја општине Панчево још у праисторијско доба, о чему говоре налазишта у насељу Старчево. Први и најстарији назив за Панчево био је Panuka (9. век). У географском делу М. Идризија "Познавање Балканског полуострва"из 1153. године Панчево се помиње први пут у писаном извору као велика трговачка варош под именом Bansif, указујући на његов привредни значај. У повељи капетана М. Таловца из 1430. године помиње се као Panとel. У записима путописца Евлије Челебије из 1690. године за Панчево се помиње назив Panzova, са описом касабе, тврђаве са џамијом и јавним грађевинама. У саставу Темишварског санџака у периоду 1552. до 1716. године Панчево се налазило под турском влашћу и било је трговачки и војни центар. У то време Панчево је имало обележје насеља са утврђењем оријенталног карактера. Након уласка у састав Аустрогарске монархије Панчево је било трговачко средиште, међу највећим од укупно тринаест дистриката у Банату, који је 1717. године имао 36 насеља и 776 домова са око 6.000 становника. Под садашњим именом Панчево се помиње почетком 18. века, као тврђава са 70 кућа, када досељени Срби оснивају Горњу, а Немци Доњу Варош. Године 1764. у граду је живело 564 домаһинства (Српско Панчево - 432, Немачко Панчево -132) и око 3.400 становника. У "мађарском лексикону" Јована Корабинског Панчево је 1786. године описано као јако трговачко место са скоро 1000 куһа. Спајањем Горње и Доње Вароши 1794. године Панчево добија карактер града. (Универзитет у Новом Саду, ПМФ-Институт за географију, 1996; www.pancevo.org).

Општина Панчево обухвата површину од $757 \mathrm{~km}^{2}$ и према Попису становништва из 2002. године у њој је живело 127.162 становника или $6,2 \%$ од укупног броја становника Војводине. Према популационој величини општина Панчево налази се на другом месту у Банату иза Зрењанина. Спада у ред густо насељьених општина са густином насељености од 168 становника $/ \mathrm{km}^{2}$ (Војводина 95 становника $/ \mathrm{km}^{2}$, Централна Србија 85 становника $/ \mathrm{km}^{2}$ ). Већу густину насељености у Војводини имају само општине Нови Сад, Стара Пазова, Сремски Карловци и Темерин. У састав општине Панчево улази 10 насеља, од чега су три градска. До 1964. године, када је насеље Војловица престало да буде самостално насеље и административно је припојено центру Општине, општину Панчево је чинило 11 насеља. Концентрација становништва у општинском центру је висока, тако да $60,6 \%$ становништва Општине живи у граду Панчеву.

Демографски фактори су веома значајни за функционалне односе између града и околине. Функционални односи између насељь ће бити интензивнији што је већи број становника у обе географске средине. Што има више људи веће су и разне потребе, па и обим њиховог задовољења (Илић Ј.,1967). Са 127.162 становника Панчево је међу пет популационо највећих општина Војводине и 14 општина Србије. У периоду демографског развоја после Првог светског рата општина Панчево бележи веће стопе пораста у односу на популацију Војводине, са тенденцијом повећавања удела становништва Панчева у укупној војвођанској популацији. Удео становништва Панчева у укупном војвођанском становништву током двадесетог века повећан је са $4,2 \%$ на 6,3\%. После Другог светског рата општина Панчево бележи релативно стабилан пораст популације, са интензивним популационим порастом у периоду 1953-1961. година, захваљујући убрзаном економском развоју за време израженог процеса индустријализације. Просечна годишња стопа раста становништва Општине кретала се 
од максималних 20,5 промила у периоду 1953-1961. година до минималних 1,2 промила у периоду 1981-1991. година.

Популациона динамика - Општина Панчево једна је од 19 општина Војводине и једина општина Баната која је у последњем међупописном периоду имала повећање броја становника. Повећању броја становника Општине у највећој мери доприноси пораст броја становника Града Панчева. После Зрењанина, Панчево је са 77.000 становника други град по популационој величини у Банату. Према методологији пописа становништва примењеној 2002. године, у последњој деценији, поред општинског центра, повећање броја становника имају само насеља Долово и Старчево.

Табела 9. Укупан број становника у периоду 1948-2002. година

\begin{tabular}{|l|c|c|c|c|c|c|c|c|c|}
\hline \multirow{2}{*}{ Територија } & \multicolumn{8}{|c|}{ Година пописа } \\
\cline { 2 - 11 } & 1948 & 1953 & 1961 & 1971 & 1981 & 1991 & $1991^{*}$ & 2002 & $2002^{*}$ \\
\hline Опитина Панчево & 70.943 & 76.283 & 93.744 & 110.780 & 123.791 & 125.261 & 122.534 & 131.938 & 127.162 \\
\hline Градска & 39.440 & 44.323 & 59.325 & 76.221 & 86.622 & 88.475 & 87.106 & 94.864 & 92.326 \\
\hline Остала & 31.503 & 31.960 & 34.419 & 34.559 & 37.169 & 36.786 & 35.428 & 37.074 & 34.836 \\
\hline Б. Брестовац & 4068 & 4289 & 4322 & 3809 & 3865 & 3715 & 3661 & 3618 & 3517 \\
\hline Б. Ново Село & 6129 & 6378 & 7225 & 7872 & 7963 & 7987 & 7564 & 8150 & 7345 \\
\hline Гпогон & 3678 & 3175 & 3230 & 3257 & 3605 & 3475 & 3285 & 3281 & 3178 \\
\hline Далово & 5983 & 6273 & 6766 & 6582 & 6836 & 6790 & 6700 & 7138 & 6835 \\
\hline Иваново & 2169 & 2196 & 2066 & 1893 & 1947 & 1439 & 1203 & 1475 & 1131 \\
\hline Јабука & 4392 & 4623 & 5245 & 5453 & 6453 & 6598 & 6441 & 6614 & 6312 \\
\hline Качарево & 5044 & 5899 & 7792 & 8088 & 8309 & 8103 & 7857 & 8009 & 7624 \\
\hline Омолица & 5084 & 5026 & 5565 & 5693 & 6500 & 6782 & 6574 & 6798 & 6518 \\
\hline Панчево & 30.516 & 34.748 & 46.679 & 61.588 & 71.009 & 72.793 & 71.801 & 78.938 & 77.087 \\
\hline Старчево & 3880 & 3676 & 4854 & 6545 & 7304 & 7579 & 7448 & 7917 & 7615 \\
\hline
\end{tabular}

*(према методу пописа 2002. године) Извор: Р3С, 20046.

Различити природни и друштвено-економски услови развоја насеља одразили су се на територијални размештај демографских потенцијала на простору Општине. Историјски континуитет постојања насеља говори да још од 1869. године Банатско Ново Село, Глогоњ и Долово имају прилично стабилне популације. Приградска насельа Качарево, Старчево и Јабука, издвојена у посебну групу у студији Центра за демографска истраживања о демографском развитку Панчева из 1970. године, имала су пораст броја становника за сто и више процената од 1869. до 2002. године (Универзитет у Новом Саду, ПМФ-Институт за географију, 1996). Популациони развој насеља општине Панчево, од педесетих година двадесетог века, омогућава класификацију насеља у неколико група према популационој динамици. У периоду 1948-2002. година, Банатски Брестовац, Глогоњ и Иваново бележе смањење броја становника. У Иванову се број становника смањио за $30 \%$, а у Банатском Брестовцу и Глогоњу за $10 \%$. Умерен популациони раст од $20 \%$ до $35 \%$ имају Банатско Ново Село, Долово и Омољица, док се интензиван популациони пораст одвијао у Јабуци и Качареву (повећање популације за $50 \%$ ) а нарочито Старчеву и Панчеву (повећање популације за више од сто одсто). У овој групи треба истаћи Качарево као специфично с обзиром да је пораст броја становника остварило до 1981. године, а највише у периоду 1953-1961. година, од када се број становника Качарева константно смањује. Године 2002. у првој групи насеља, којој припада само насеље Иваново, живело је $1 \%$ становништва Општине, у другој групи $5 \%$, трећој $16 \%$, четвртој $11 \%$ и петој $67 \%$ од укупног становништва општине Панчево.

Највећи популациони пораст у последњих педесет година имају приградска насеља изразито неаграрна по типу, са до $10 \%$ пољопривредног становништва. Следе 
Омољица, Долово и Банатско Ново Село умереног популационог раста са повољним геосаобраһајним положајем (ближе општинском центру и на саобраћајницама регионалног, а Банатско Ново Село и међународног значаја). У сва три насеља у ширем залеђу општинског центра и слабијих саобраћајних веза број становника се смањује, уз концентрацију становништва у Панчеву и Старчеву.

Промене у просторном размештају становништва по насељима показују да је Банатско Ново Село деведесетих година прошлог века после Качарева било насеље са највише становника у општини Панчево, изузимајући општински центар. Године 2002. Качарево и Старчево су готово исте популационе величине, а затим следи Банатско Ново Село као треће насеље по популационој величини и највеће сеоско насеље у општини. У фази најинтензивнијег демографског развоја налази се Старчево, с обзиром да је и према старој и према новој методологији пописа становништва имало највише становника 2002. године од свог постанка (Р3С, 20046).

Урбанизација - Панчево спада у групу високо урбанизованих општина, са уделом градског у укупном становништву од $72 \%$, док је просек за Војводину $57 \%$ односно $56 \%$ на нивоу целе земље. На изражен процес примарне урбанизације на подручју општине Панчево упућује конщентрација становништва у општинском средишту (у граду Панчеву 1948. године живело је $43 \%$, а 2002 . године $60 \%$ панчевачког становништва). Као резултат миграција село-град, подстакнутих процесом интензивне индустријализације у периоду након Другог светског рата, учешће градског у укупном становништву Панчева повећано је са $58,1 \% 1953$. године на $71,9 \% 2002$. године (за Војводину као целину са $29,5 \%$ на $57 \%$ у истом периоду). Процес урбанизације у Војводини, који је резултирао просторним преразмештајем становништва, одвијао се равномерније у односу на Централну Србију. Као главне носиоце процеса урбанизације у Србији аутори публикације "Становништво и домаћинства СР Југославије према попису 1991. године” истичу насеља која су још приликом Пописа становништва из 1948. године имала више од 5.000 становника, тј. оне првобитне центре који су константно јачали своје градске функције и привлачну моћ за досељавање (SZS,CDI-IDN,1995). У овој групи традиционалних градских насеља, која су прва отпочела да примају таласе јаког досељавања становништва, током и по завршетку Другог светског рата, налази се и Панчево. У Панчеву живи 6,5\% градског становништва Војводине, и ово становништво заједно са градским становништвом Зрењанина, Суботице и Новог Сада чини готово $40 \%$ градског становништва Војводине.

Пораст градског становништва Панчева одвијао се динамичније од пораста укупног становништва Општине. Поларитет између демографског развоја сеоских и градских насеља у Панчеву и концентрација становништва у градским насељима изражени су од шездесетих година прошлог века. Индекси раста градског становништва у односу на укупно становништво општине Панчево били су највеһи у периодима 1953-1961. и 1961-1971. година, у складу са друштвено-економским процесима везаним за изградњу највећих индустријских постројења на простору Општине. Током двадесетог века градско становништво Панчева се повећало скоро четири пута, док се укупно становништво у истом периоду удвостручило, те процес просторно-демографске поларизације постаје све израженији на територији општине Панчево. Сеоска насеља су дала највећи допринос порасту броја становника Општине седамдесетих година прошлог века када су са $20 \%$ учествовала у порасту броја општинског становништва. Од укупног повећања броја становника Општине у последњих педесет година, у сеоским насељима остварено је свега $9,2 \%$, а у градским 90,8\%. У деценији 1991-2002. година градска популација Панчева повећала се за $6 \%$, док се сеоска популација у истом периоду смањила за $2 \%$. Носиоци демографског 
развоја Општине су Панчево и Старчево са преко $65 \%$ од укупног становништва Општине.

Табела 10. Промене броја становника Олштине и Града Панчева*

\begin{tabular}{|c|c|c|c|c|}
\hline \multirow{2}{*}{ година } & \multicolumn{2}{|c|}{ Општина } & \multicolumn{2}{c|}{ Град } \\
\cline { 2 - 5 } & $\begin{array}{c}\text { Број } \\
\text { становника }\end{array}$ & $\begin{array}{c}\text { Индекс } \\
\text { промене }\end{array}$ & $\begin{array}{c}\text { Број } \\
\text { становнка }\end{array}$ & $\begin{array}{c}\text { Индекс } \\
\text { промене }\end{array}$ \\
\hline 1921 & 60.582 & & 22.542 & \\
\hline 1931 & 63.158 & 104,3 & 25.746 & 114,2 \\
\hline 1948 & 70.943 & 112,3 & 30.516 & 138,2 \\
\hline 1953 & 76.283 & 107,5 & 34.748 & 113,9 \\
\hline 1961 & 93.744 & 122,9 & 46.679 & 134,3 \\
\hline 1971 & 110.780 & 118,2 & 61.588 & 131,9 \\
\hline 1981 & 123.791 & 111,7 & 71.009 & 115,3 \\
\hline 1991 & 125.261 & 101,2 & 72.793 & 102,5 \\
\hline 2002 & 131.938 & 105,3 & 78.938 & 108,4 \\
\hline
\end{tabular}

•Подаци за град Панчево укључују и насеље Војловицу ради упоредивости података. Извор података: CDI-IDN,1970;P3C,20046.

Поред примарне урбанизације, на подручју Општине заступљена је и секундарна урбанизација, која се испољава кроз трансформацију неградских насеља у градска. Секундарна урбанизација, као квалитативно виши ниво урбанизације, огледа се у просторном ширењу града односно спајању насеља Војловице са градским центром и губљењу њеног статуса самосталног насеља од 1964. године. Према Илићу почетак урбанистичког срастања Војловице и Панчева започео је тридесетих година двадесетог века подизањем стакларе између ова два насеља, након које је интензивирана и изградња куһа на овом простору. Изградњом насеља Топола и Стрелиште, као и грађењем азотаре и рафинерије Панчево и Војловица су постали јединствена просторна целина (Илић Ј., 1967).

Поред промена у просторном размештају становништва Општине, један од демографских аспеката урбанизације, као показатељ концентрације и поларизације становништва, јесу и промене у густини насељености. На промене у просторној организацији насељености деловао је локални и регионални развој. Са просечном густином насељености од 146 становника $/ \mathrm{km}^{2}$ Панчево се седамдесетих година прошлог века налазило међу једанаест општина Војводине са 101 до 150 становника $/ \mathrm{km}^{2}$ које су концентрисале $30 \%$ војвођанског становништва (Стојановић Б., 2003). Актуелна просторно-демографска дистрибуција становништва, 2002. године, показала је да Панчево (168 становника $/ \mathrm{km}^{2}$ ) припада категорији густо насељених општина (са густином насељености од 151 до 200 становника $/ \mathrm{km}^{2}$ ). У односу на суседне општине, које имају мање од 100 становника $/ \mathrm{km}^{2}$, али и просек Војводине, Панчево има знатно веhy густину насељености, нарочито имајући у виду релативно ниску густину насељености у региону Баната која је 2002. године износила 70 становника $/ \mathrm{km}^{2}$. Размештај становништва у Банату је доста неуједначен, па се средња удаљеност између два становника у метрима, као показатељ концентрације и дисперзије становништва, креће од 192,2 за Сечањ до 83,2 за Панчево (Кицошев С. и др., 2005). Просечна густина насељености на простору Општине повећана је у периоду 1948-2002. година са 94 на 168 становника $/ \mathrm{km}^{2}$. У граду густина насељености достиже 489 становника $/ \mathrm{km}^{2}$, а у Иванову свега 18 становника $/ \mathrm{km}^{2}$.

Поларизационо дејство града утицало је на стално смањење броја сеоског становништва и промене његових структура. Текући демографски процеси који се одвијају у појединачним насељима општине Панчево, нарочито биолошка депопулација и интензивно старење становништва, упуһују на очекивања о даљем смањењу просечне густине насељености у сеоским насељима, као индикатора промена у демографском 
развитку, уз наставак концентрације становништва у градском средишту и околним прнградским насељима.

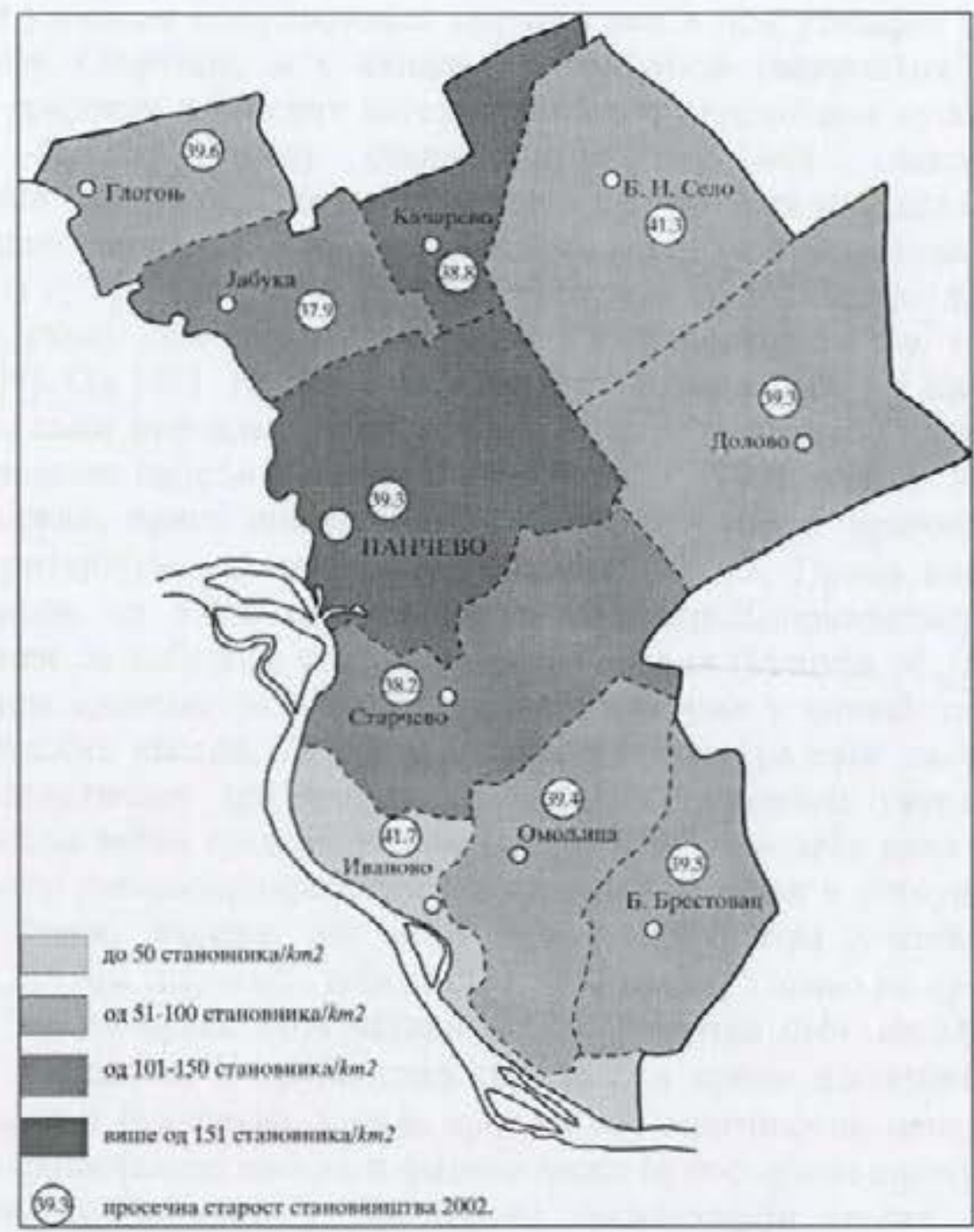

Карта 5. Густина насељености и просечна старост становништва општине Панчево 2002. године

Мрежа насеља - Развитак насељености у Војводини одвијао се под друкчијим условима, како географским, тако и политичко-историјским, економским и културним. Отуда типолошка структура и просторна организација насељености суштински разликују Војводину од свих осталих области Србије (Радовановић М.,1996). Географски услови, који су отежавали насељавање, као и политичко-историјски догађаји одразили су се на развој мреже насеља у Банату, и релативно мали број и неравномеран размештај банатских градова. Положај, међусобна удаљеност насеља у мрежи насеља, као и удаљеност од градског центра (просторна организација мреже насеља) значајан су фактор утицаја на обим и правце дневних миграција становништва Панчева. Мрежу насеља Општине чини десет насеља, у којима је 2002. године живело је 127.162 становника. Просечна популациона величина насеља 1948. године износила је 6.449 становника односно 12.716 становника 2002. године. С обзиром да је Војловица била самостално насеље до 1964. године, те да је општина Панчево имала 1948. године 11 насеља, са садашњим бројем насеља просечна величина насеља Општине у то време износила би 7.094 становника. У периоду 1948-2002. година, просечна популациона величина насеља повећала се за преко 5.000 становника, од тога се просечна величина сеоских насеља повећала за 500 становника, а градских чак за 4500 . Томе је највише допринео пораст броја становника града Панчева и Старчева. Године 2002. просечна 
величина градских насеља Општине, без општинског центра, износила је 7.620 становника, а сеоских насеља 4.977 становника. У односу на просек за Војводину сеоска насеља Панчева просечно су двоструко веһа.

Промене просечне величине насеља општине Панчево, према типу, одвијале су се не само под утицајем популационих кретања већ и под утицајем промене статуса насеља у оквиру Општине, а у складу са применом различитих критеријума за класификацију градских и сеоских насеља приликом спровођења сукцесивних пописа становништва. Према Попису становништва из 1948. године, на основу административног принципа, Панчево је добило статус градског насеља, чинеһи једно од девет градских насеља у Војводини, односно 34 градска насеља у Србији. Ова насеља задржала су градски статус по свим пописима становништва до 2002. године и често се у стручној литератури означавају као "традиционални градови Србије" (Stevanović, 2004). Од 1971. године статус градског насеља добијају Качарево и Јабука. Качарево према свим наредним пописима становништва задржава овај статус, док је Јабука статус градског насеља имала само према попису 1971. године. Издвајање Јабуке као градског насеља, према попису 1971. године, резултат је примене демографскостатистичког критеријума за издвајање градских насеља. Према овом критеријуму Јабука је са више од 5.000 становника и $70 \%$ непољопривредног становништва испуњавала услове за добијање статуса градског насеља (Мацура М., 1954). Beћ 1981. године, применом административно-правног критеријума у попису становништва, за дефинисање градских насеља, Јабука је изгубила статус градског насеља. Недостатке демографско-статистичког критеријума за издвајање градских насеља, на примеру приградских насеља већих градова, истиче Вреск (1990) наводећи како у тим насељима процентуални удео непољьпривредног становништва не може у потпуности указати на функционални значај насеља, јер већи део становништва учествује у дневним миграцијама ка другом (најчешће већем) суседном месту. Управо на примеру Јабуке то се и потврђује јер су преко $60 \%$ активног становништва овог насеља 1971. године чинили дневни мигранти. У групи градских насеља према пописима 1961. и 1971. године налазила се и Војловица, која је припајањем општинском центру 1964. године изгубила статус самосталног насеља и физиономски се постепено интегрисала са самим градом утичући на промене у просторној организацији мреже насеља. Према последњем извршеном попису становништва једно од три градска насеља општине Панчево, заједно са Качаревом и Панчевом чини Старчево које је статус градског насеља добило 1981. године.

Утицај градова на приградска насеља огледа се како у демографским, тако и у функцијским и физиономским променама. Ове промене најприметније су у приградским насељима. Анализом пораста броја становника и удела непољопривредног становништва Ћурчић издваја десет приградских насеља у Банату. Највећи број приградских насеља у којима доминира непољопривредно становништво уједно карактерише и пораст броја становника, претежно као резултат позитивног миграционог салда. Велики удео непољопривредног становништва је највећим делом последица бројности дневних миграната, јер се економска и морфолошка трансформација приградских насеља одвија знатно спорије од демографске. Шездесетих година прошлог века обележје приградског насеља Панчева имала је само Војловица. Према резултатима пописа 1971. године то су насеља Старчево, Јабука, Глогоњ и Омољица. Године 1981. из ове групе иступају насеља Глогоњ и Омољица, а 1991. године у Панчеву су издвојена као приградска насеља Јабука, Качарево и Старчево. На простору Општине налазе се и два формална насеља: Скробара и Стари Тамиш. Нуклеус насеља Скробара је стара фабрика скроба изграђена уз пут КовачицаПанчево, око 4 km југозападно од Качарева. Насеље Стари Тамиш је велико мајурско 
насеље на пола пута између Панчева и Долова настало после Другог светског рата на једном од имања ПІК Тамиш из Панчева. Већи део насељь налази се источно од раскрснице према Долову, а мањи према Ковину. Ово насеље знатно доприноси порасту броја становника Долова у последњем међупописном периоду (Ћурчић C., 1993,2004).

У структури насеља Панчева према величини преовладавају насеља средње величине (од 2.000 до 9.999 становника). Само једно насеље је мало (до 2.000 становника) у складу са мањим уделом ове величинске категорије насеља у структури насеља Војводине у односу на Централну Србију.

Табела 11. Класификација насеља општине Панчево према популационој величини

\begin{tabular}{|c|c|c|c|c|c|c|c|}
\hline Потулациона величина насеља & \multicolumn{6}{|c|}{ Број насеља према години пописа } \\
\cline { 2 - 8 } (6рој становника) & 1948 & 1953 & 1961 & 1971 & 1981 & 1991 & 2002 \\
\hline до 1.999 & - & - & - & 1 & 1 & 1 & 1 \\
\hline $2.00-4.999$ & 5 & 5 & 4 & 2 & 2 & 2 & 2 \\
\hline $5.00-9.999$ & 4 & 4 & 5 & 6 & 6 & 6 & 6 \\
\hline $10.000-49.999$ & 1 & 1 & 1 & - & - & - & - \\
\hline$>50.000$ & - & - & - & 1 & 1 & 1 & 1 \\
\hline
\end{tabular}

Извор података: CDI-IDN,1970;P3C,20046.

У периоду 1948-2002. година смањен је број насеља са 2.000-5.000 становника у корист повећања броја насеља са 5.000-10.000. Овој групи насеља припада чак $60 \%$ насеља општине. Најмање сеоско насеље Иваново, које бележи и највеһе смањење броја становника у последњих шездесет година, прешло је из величинске категорије насеља 2.000 - 5.000 становника којој је припадало 1971. године у категорију насеља до 2.000 становника. Град Панчево у исто време прелази у категорију насеља са више од 50.000 становника, чинећи 2002. године једно од пет градских насеља Војводине које припада категорији насеља ове популационе величине. Према методологији Пописа становништва из 2002. године највеһе сеоско насеље је Качарево са 7.624 становника. "Качарево и Омољица су према Просторном плану Општине из 1989. године издвојени као секундарни центри развоја у општини Панчево" (Група аутора 1989, према Милетић Р., 1999).

\section{3. Природна и миграциона компонента демографског развоја као детерминанте обима и територијалног домета дневних миграција}

У 17. и 18. веку досељавања су била главни узрок пораста броја становника на простору наше земље северно од Саве и Дунава. Захваљујући бројним усељеничким таласима, од 1720. до 1787. године становништво Баната се увећало осамнаест пута (Група аутора,1953, према Радовановић М.,1996). 3бог тешког прилагођавања многих насељеника нездравим мочварним теренима, смртност је била велика, те је природни прираштај у порасту становништва и развоју насељености имао споредну улогу. У Војводини удео природне компоненте у развитку насељености и порасту становништва у већој мери долази до изражаја тек у 19. веку, али и тада са вредностима које су биле знатно испод природног прираштаја у Кнежевини Србији. Према мађарским изворима, у првој деценији 20. века природни прираштај становништва Војводине износио је 11 промила (у Банату 8,8\%) (Радовановић М.,1996).

Значај појединих компоненти популационе динамике за демографски развитак на простору Општине мењао се током времена. Ако се посматра појединачан допринос компоненти популационог раста порасту броја становника општине Панчево уочава се преовлађујући утицај миграција у периоду 1961-1970. година, затим јачање компоненте природног прираштаја, потом деловање само природног прираштаја и у последњој 
међупописној декади деловање само миграција на пораст броја становника. Стопа пораста броја становника Општине у периоду 1961-1971. година била је међу највећим у Војводини, док је у истом периоду на простору Баната забележен пораст од свега 0,2 промила). Интензивно досељавање становништва имало је преовлађујући утицај на пораст броја становника општине Панчево у то време. У декади 1981-1991. година негативан миграциони салдо, уз ниске вредности природног прираштаја допринео је релативном стагнирању броја становника на простору општине Панчево. С обзиром на постојећи ниво обнављања становништва, за пораст броја становника у последњем међупописном периоду у потпуности су заслужне миграције.

Табела 12. Компоненте популационих промена

\begin{tabular}{|c|c|c|c|c|}
\hline \multicolumn{5}{|c|}{ Просечне годишње стопе (у промилима) } \\
\hline & $1961-1970$ & $1971-1980$ & $1981-1990$ & $1991-2002$ \\
\hline \multicolumn{5}{|c|}{ Војводина } \\
\hline Укупан пораст & 5,1 & 4,1 & $-1,0$ & 2,8 \\
\hline Природни прираштај & 5,1 & 3,5 & 0,6 & $-3,8$ \\
\hline Миграциони сапдо & 0,0 & 0,6 & $-1,6$ & 6,6 \\
\hline \multicolumn{5}{|c|}{ Опитина Панчево } \\
\hline Укупан пораст & 16,7 & 11,1 & 1,2 & 3,4 \\
\hline Природни прираштај & 7,5 & 7,5 & 3,9 & $-2,2$ \\
\hline Миграциони салдо & 9,2 & 3,6 & $-2,7$ & 5,6 \\
\hline
\end{tabular}

Извор података: Универзитет у Новом Саду, ПМФ - Институт за географију, 1996, CDI-IDN, 2004. Кицошев С. и др.,2005.

Од укупног демографског пораста на простору Општине у последњих четрдесет година, природни прираштај становништва чинио је $54,7 \%$, а осталих $45,3 \%$ механички прилив становништва (Кицошев С. и др.,2005). У последњем посматраном периоду, као резултат деловања негативних вредности компоненте природног обнављања, становништво Општине се умањило за 3.050 становника, док се механичким путем број становника увећао за 7.678 становника. Представљени тренд указује на смањење улоге прнродног прираштаја као фактора развоја становништва и снажно деловање миграција на дисбаланс у демографском развоју и концентрацију становништва у појединим насељима Општине. Наставак ових тенденција одразиће се на многе сегменте развоја општине Панчево али и на одвијање процеса дневних миграција становништва (промене обима и токова дневних миграција).

Табела 13. Компоненте популационих промена 1991-2002. година

\begin{tabular}{|c|c|c|c|c|c|c|}
\hline \multirow{2}{*}{ Територија } & \multicolumn{2}{|c|}{$\begin{array}{c}\text { Пораст/пад } \\
\text { становништва }\end{array}$} & \multicolumn{2}{|c|}{$\begin{array}{l}\text { Природни } \\
\text { прираштај }\end{array}$} & \multicolumn{2}{|c|}{$\begin{array}{l}\text { Миграциони } \\
\text { салдо }\end{array}$} \\
\hline & Број & $\begin{array}{l}\text { Crona } \\
(\% 0)\end{array}$ & Бpoj & $\begin{array}{l}\text { Crona } \\
(\% 0)\end{array}$ & Број & $\begin{array}{l}\text { Crona } \\
(\% 0)\end{array}$ \\
\hline Б. Брестовац & -144 & $-3,6$ & -187 & $-4,7$ & 43 & 1,1 \\
\hline Б. Ново Село & -219 & $-2,7$ & -431 & $-5,3$ & 212 & 2,6 \\
\hline Гnorots & -107 & $-3,0$ & -153 & $-4,3$ & 46 & 1,3 \\
\hline Долово & 135 & 1,8 & -244 & $-3,3$ & 379 & 5,1 \\
\hline Иваново & -72 & $-5,6$ & -148 & $-11,5$ & 76 & 5,9 \\
\hline Јабука & -129 & $-1,8$ & -18 & $-0,3$ & -111 & $-1,6$ \\
\hline Качарево (r) & -233 & $-2,7$ & -170 & $-2,0$ & -63 & $-0,7$ \\
\hline Омољица & -56 & $-0,8$ & -113 & $-1,6$ & 57 & 0,8 \\
\hline Панчево (r) & 5286 & 6,5 & -1538 & $-1,9$ & 6824 & 8,3 \\
\hline Старчево (r) & 167 & 2,0 & -49 & $-0,6$ & 216 & 2,6 \\
\hline Оштина Панчеео & 4628 & 3,4 & -3050 & $-2,2$ & 7678 & 5,6 \\
\hline Војеодина & 61.797 & 2,8 & -82.607 & $-3,8$ & 144.404 & 6,6 \\
\hline
\end{tabular}

*(према методу пописа 2002. године) Извор података: Р3С, 20046;Р3С,2005. 
Анализа промена учешћа појединих насеља у променама броја становника општине Панчево показују да је у периоду 1953-1961. година после градског центра највећи допринос порасту броја становника Општине дало насеље Качарево, а у периоду 1971-1981. година насеље Јабука (захваљујући највећој стопи наталитета на нивоу Општине у овом периоду). У последњем међупописном периоду порасту броја становника Општине поред градског центра највише су допринела насеља Старчево и Долово примивши нове становнике (Р3С,2005).

\section{Природно кретање становниитва}

Подручје општине Панчево, као и целокупну територију Војводине, одликује дуготрајан пад природног прираштаја, услед пада стопе наталитета и пораста стопе морталитета, све до негативних вредности. Садашњи ниво обнављања становништва резултат је како промена у природном прираштају, тако и непосредних и посредних ефеката бројних миграционих процеса који су се одвијали на овом простору. У првој половини двадесетог века приметно је стално опадање стопа наталитета и морталитета, осим забележеног пораста наталитета у компензационом периоду после Другог светског рата. До 1954. године, просечне годишње стопе наталитета, морталитета и природног прираштаја забележене на подручју Јужног Баната, могу се сматрати приближно истим и за становништво Панчева. Оне су се кретале од $35,7 \%$ за наталитет, $28 \%$ за морталитет и 7,7\% за природни прираштај у периоду 1901-1910. година, до $24 \%$ за наталитет, $14,6 \%$ за морталитет и 9,4\% за природни прираштај у периоду 19471954. година (CDI-IDN,1970). У првим годинама после Другог светског рата у Општини је, у вези са компензационим периодом, дошло до пораста наталитета, као и броја склопљених бракова. Пораст наталитета нарочито је био изражен у Качареву. У односу на остала насеља Старчево, Качарево, Јабука и Град Панчево имали су шездесетих година прошлог века веће стопе наталитета и мање стопе морталитета. Просечна годишња стопа природног прираштаја износила је 13,2\%, у периоду 1948-1953. година, односно 12,1\%о у периоду 1953-1961. година (Илић Ј., 1967).

Шездесетих и седамдесетих година прошлог века на територији општине Панчево наталитет је био већи у односу на шири простор Војводине, да би касније ове разлике почеле да се смањују бржим опадањем стопа наталитета у Панчеву. Наталитет у Панчеву у то време био је под утицајем структуре и репродуктивних норми становништва досељеног за време колонизације (из крајева у којима је репродукција била традиционално висока) као и досељавања фертилног и радно способног становништва у текуһем процесу урбанизације. Подмлађивање становништва досељеницима утицало је на вредности стопа наталитета које су шездесетих година биле највеће у Јабуци и Качареву. Ефекти досељавања присутни су били у овим насељима и осамдесетих година двадесетог века у виду најнижих вредности опште стопе смртности на нивоу Општине, услед споријег одвијања процеса старења становништва.

У последњих четрдесет година наталитет на простору општине Панчево смањио се са 16,3 на 10,1 промила, односно за $6,2 \%$. Општа стопа морталитета повећала се са 8,9 промила на 12,4 промила. На смањење вредности стопе природног прираштаја на простору Општине значајније је деловала стопа наталитета чије су промене у посматраном периоду биле интензивније. Ипак и као такав природни прираштај становништва општине Панчево у другој половини 20. века константно има веће вредности од просека Војводине и Баната захваљујући како вишим стопама наталитета, тако и нижим стопама морталитета на простору Општине. У декади 1991-2001. година на разлике у природном прираштају становништва панчевачке општине у односу на 
војвођански и банатски просек (мање негативне вредности стопе природног прираштаја) првенствено делује мањи морталитет на простору Општине.

Табела 14. Природно кретање становништва

\begin{tabular}{|c|c|c|c|c|}
\hline \multicolumn{5}{|c|}{ Просечне годишње стопе (у промилима) } \\
\hline & $1961-1970$ & $1971-1980$ & $1981-1990$ & 1991-2002 \\
\hline \multicolumn{5}{|c|}{ Војводина } \\
\hline Наталитет & 14,8 & 14,1 & 12,7 & 10,5 \\
\hline Морталитет & 9,7 & 10,6 & 12,1 & 14,2 \\
\hline Природни прираштај & 5,1 & 3,5 & 0,6 & $-3,8$ \\
\hline \multicolumn{5}{|c|}{ Банат } \\
\hline Наталитет & 14,4 & 13,7 & 12,5 & 10,2 \\
\hline Морталитет & 9,8 & 11,0 & 12,7 & 15,0 \\
\hline Природни прираитај & 4,6 & 2,7 & $-0,2$ & $-4,8$ \\
\hline \multicolumn{5}{|c|}{ Општина Панчево } \\
\hline Наталитет & 16,3 & 16,4 & 13,6 & 10,1 \\
\hline Mopranитет & 8,9 & 8,9 & 9,7 & 12,4 \\
\hline Природни прираштај & 7,5 & 7,5 & 3,9 & $-2,2$ \\
\hline
\end{tabular}

Извор података: Универзитет у Новом Салу, ПМФ - Институт за географију, 1996.; CDI-IDN, 2004; Кицошев C. и др., 2005; P3C, 2005.

Ако се посматра на нивоу насеља, у периоду 1961-1971. година природни прираштај у граду Панчеву био је у рангу вредности за Општину, док у декади 19912002. година, на нешто мању негативну вредност стопе природног прираштаја у граду у односу на Општину пресудно утиче нижа стопа морталитета градског становништва. Специфично је насеље Иваново у коме је биолошка депопулација започела још седамдесетих година прошлог века, од декаде 1971-1981. година, од када је природни прираштај у овом насељу негативан.

Табела 15. Просечне годишње стопе наталитета и морталитета у општини Панчево 1991-2002. год.

\begin{tabular}{|l|c|c|c|c|}
\hline \multirow{2}{*}{ Територија } & \multicolumn{2}{|c|}{ Живорођени } & \multicolumn{2}{c|}{ Умрли } \\
\cline { 2 - 5 } & 6 рој & $\% 0$ & 6 бој & $\% 0$ \\
\hline Банатски Брестовац & 394 & 10,0 & 581 & 14,7 \\
\hline Банатско Ново Село & 841 & 10,3 & 1272 & 15,5 \\
\hline Глогон & 319 & 9,0 & 472 & 13,3 \\
\hline Долово & 862 & 11,6 & 1.105 & 14,8 \\
\hline Иваново & 117 & 9,1 & 264 & 20,6 \\
\hline Јабука & 718 & 10,2 & 736 & 10,5 \\
\hline Качарево (r) & 842 & 9,9 & 1.012 & 11,9 \\
\hline Омолица & 696 & 9,7 & 809 & 11,2 \\
\hline Панчево (r) & 8.256 & 10,1 & 9.794 & 12,0 \\
\hline Старчево (r) & 889 & 10,7 & 938 & 11,3 \\
\hline Општина Панчево & 13.933 & 10,1 & 16.982 & 12,4 \\
\hline
\end{tabular}

Извор података: Р3С, 2005.

У периоду 1991-2002. година, просечна годишња стопа наталитета посматрано по насељима креће се између 9 и 10 промила. Највеһа је у Долову и износи $11,6 \%$. Шездесетих година прошлог века најмање вредности стопе наталитета у општини износиле су 13,4 промила за Долово односно 13 промила за Банатско Ново Село. Најмање вредности стопе наталитета у то време биле су значи веће од актуелне вредности стопе наталитета на нивоу Општине 2002. године. Насупрот томе, стопа морталитета на нивоу Општине у последњем међупописном периоду има вредности које је шездесетих година имало насеље са највећом стопом морталитета у општини - 
Иваново. Просечна годишња стопа морталитета у периоду 1991-2001. година креће се између 10 и 15 промила, осим Иванова где је вредност ове стопе највеһа и износи $20,6 \%$. Као резултат изузетно високе стопе морталитета ово насеље, ван значајнијих саобраћајних праваца, бележи највеће смањење броја становника у последњем међупописном периоду. До пораста смртности на подручју Општине дошло је услед одмаклог процеса старења становништва у великом броју насеља. Као резултат нешто повољније старосне структуре становништва градска и приградска насеља имају нешто мању стопу морталитета.

\section{Миграицје становниитва}

Формирању демографских потенцијала општине Панчево допринели су бројни и разноврсни миграциони процеси. Међу њима се издвајају планске колонизације, миграције село-град, миграције на рад у иностранство и избегличке миграције. Насељавање Панчева одвијало се под утицајем политичких али и економских интереса државе у чијем се саставу Банат налазио, те се становништво досељавало и одсељавало како из економских, тако и из других разлога - промене државних граница, ратови. У последњем међупописном периоду Панчево се налази међу десет најпривлачнијих општина Србије за досељавање.

Током 18. и у првој половини 19. века миграционе процесе на данашњем простору општине Панчево обележиле су колонизације становништва извршене у више наврата. Највише су се досељавали Немци и Мађари, док су друге етничке групе досељаване у знатно мањем броју. "У Банат је колонизовано између 40.000 и 60.000 Немаца" (Радовановић М., 1996). Као последица колонизација дошло је до промена у популационој динамици али и у структурама становништва (Немци су 1921. године чинили већинско становништво у насељима Омољица, Банатски Брестовац, Јабука и Качарево). Промене у етничкој структури становништва овог подручја, до тада насељеног већински српским становништвом, приметне су и данас. У току тзв. Мерсијеве колонизације, у периоду 1717-1740. година, немачки колонисти на простору данашње општине Панчево формирали су Доњу Варош (немачко насеље), поред постојећег српског насеља Горње Вароши. Крајем 18. и почетком 19. века, у другој великој колонизацији Немаца на ове просторе (тзв. терезијанска колонизација) настало је насеље Качарево. Качарево - тадашњи Францфлелд основано је насељавањем 120 немачких породица. У исто време Немци су досељени у већем броју и у Глогоњ и Јабуку. Планско досељавање Румуна из Ердеља у Панчево и Банатско Ново Село одвијало се у периоду 1765-1768. година. Део Румуна досељен је и нешто касније, у периоду 1783-1784, година, у Јабуку, Глогоњ, Старчево, Омољицу и Панчево. Мађари су насељавани интензивније од 1867. године у Војловицу и Иваново. Године 1869. мањи број Бугара досељен је у Иваново. Словаци су досељавани почетком XIX века у мањим групама у Иваново и касније Војловицу (Универзитет у Новом Саду, ПМФИнститут за географију, 1996).

Најмасовније планско досељавање становништва на подручје општине Панчево после Другог светског рата, било је у периоду 1946-1947. година. Панчевачка општина заједно са Новим Садом, Новом Пазовом, Апатином, Белом Црквом и Инђијом била је меלу пет општина Војводине у које је највише колонизирано становништво из свих крајева земље након Другог светског рата. На простор Општине колонизирано је укупно 2.635 домаћинстава са 15.518 чланова. Највише колониста било је из Македоније 7.093, затим из Централне Србије 6.273, Босне и Херцеговине 1.004 и Хрватске 582. (Војвођански архив, фонд 184, Нови Сад према Универзитет у Новом Саду, ПМФ-Институт за географију, 1996). Највише колониста досељено је у Качарево 
(648 домаћинстава), затим у Јабуку (563), Банатски Брестовац (446), Омољицу (445), Глогоњ (275), Старчево (159), и Панчево (70). Јабука, Качарево и Глогоњ насељени су претежно Македонцима, док су у Банатски Брестовац, Старчево и Омољицу колонисти дошли претежно из Централне Србије (CDI-IDN,1970). Неколико насеља Општине после Другог светског рата под утицајем миграција добила су делимично или потпуно ново становништво. Године 1948. колонисти су чинили $21,9 \%$ становништва Општине. у Јабуци је исте године од укупног становништва чак 78,3\% било колониста, у Банатском Брестовцу 64,3\%, Омољици 49,4\%, Глогоњу 50,2\% и Старчеву 20,5\% (Ђурђев Б., 1986). Колонизација се на демографски развој насеља Панчева одразила не само директно кроз бројност становништва, већ и индиректно делујући на компоненте природног кретања становништва, старосно-полну, етничку структуру становништва и структуру домаћинстава према броју чланова. Колонистичка домаһинства имала су у просеку 5,9 чланова. Истиче се да су колонисти примали новине брже од староседелаца, те да су брже прихватали градски начин живота и одлазили са села у периоду урбанизације (CDI-IDN, 1970).

Стихијско досељавање становништва на простор општине Панчево одвијало се у периоду између два светска рата и у периоду после колонизације 1946-1947. година. У великом броју првобитно су се досељавали рођаци и пријатељи колониста, који су уз њихову помоћ куповали имања и запошљавали се, али и непољопривредно становништво за чијим радом је после Другог светског рата постојала потреба у граду. Одређени број колониста се и одселио из Панчева након стицања права на продају земље (15 година након добијања имања). Највише ових породица одсељено је из Качарева. Многи од њих одселили су се у Панчево или Београд (CDI-IDN,1970). На њихову земљу која се могла јефтино купити дошли су мигранти углавном из Централне Србије. У Долово су нпр. од 1946. до 1971. године дошла 2.377 досељеника. Највише миграната дошло је са подручја Пирота, Лесковца и Врања (Универзитет у Новом Саду, ПІМФ-Институт за географију, 1996). Интензитет досељавања становништва на простор општине Панчево био је највећи после Другог светског рата, а нарочито у периоду 1958-1961. година у време убрзаног привредног развоја града. После Другог светског рата претежно су се мигранти досељавали у град и насеља са добрим саобраћајним везама према градовима, док су остала насеља примила мали број становника. У насеља ближе Панчеву становништво се одсељавало како би имало мање трошкове школовања деце и било ближе непољопривредним запослењима. У периоду 1948-1953. година, Панчево и његова приградска насеља имали су позитиван миграциони салдо, док су сеоска насеља имала мањи укупан пораст броја становника од природног прираштаја забележеног у то време. Према Илићу у овом периоду у Панчево се доселило око 15.500 становника а иселило око 8.000 (Илић Ј.,1967).

Шездесете и седамдесете године двадесетог века у општини Панчево, као и у целој Србији обележиле су економски мотивисане миграције, правца село - град и из пољопривредних ка привредно развијенијим подручјима. Панчевачка општина, као једна од четрнаест општина Војводине са мање од $40 \%$ пољопривредног становништва шездесетих година, била је изразито привлачна за досељавање. После општине Нови Сад општина Панчево била је други по величини имиграциони центар Војводине у периоду 1961-1971. година, са стопом годишњег миграционог салда од 9,2 промила. У пресељавању је учествовало претежно младо становништво (54\% од укупног броја миграната имало је од 15 до 34 године), које је у највећој мери долазило из пољопривредног сектора (CDI-IDN, 1979). У периоду 1971-1981. година, досељавање на простор Општине и даље је било интензивно. Панчево је било међу девет општина Војводине у које је досељено $63 \%$ од укупног броја спољних досељеника. Привлачност ових општина за досељавања резултат је њиховог привредног централитета, а 
досељавања су тим већа уколико су потпомогнута близином спољних административних центара, као што је то у случају Панчева (Ђурђев Б.,1986). Поред усељавања на простор Општине, седамдесетих година прошлог века становништво Панчева се исељавало према подручјима Централне Србије, пре свега Београду, а у овом периоду започиње и одлазак становништва на рад у иностранство.

Након искључиво економски мотивисаних миграција од шездесетих година 20. века, у последњој деценији забележен је прилив принудних миграната на простор Општине. Као последица грађанског рата на просторима бивше Југославије у Панчево је у последњем мећупописном периоду досељено 8.294 лица. Досељавање избеглица допринело је порасту броја становника Општине у последњој међупописној декади и поред негативног природног прираштаја и исељавања око 600 становника у периоду 1991-2002. година. Удео избеглица у укупном становништву Општине 2002. године износио је $6,5 \%$. Највише избеглица досељено је из Хрватске (5.623 или $68 \%$ ), а затим из Босне и Херцеговине (2.302 или 28\%) (Министарство за људска и мањинска права Србије и Црне Горе,2004). Једна четвртина становништва досељеног на простор општине Панчево према Попису становништва из 2002. године (15.658 лица) доселила се у периоду 1991-2002. година, након рата на простору бивше Југославије. Они су највише допринели актуелном демографском развоју Банатског Новог Села, Иванова, Панчева и Старчева где чине више од $10 \%$ од укупног становништва (РЗС,20046).

У међународне миграционе токове становништво Општине је мало укључено. Од 1900. до 1931. године изражена је била емиграција становништва Панчева у Америку, нарочито из Банатског Новог Села, Јабуке и Глогоња (Универзитет у Новом Саду, ПМФ-Институт за географију, 1996). Највише Панчеваца на привременом раду у иностранству било је осамдесетих година прошлог века (4.407 или $3,6 \%$ од укупног становништва Општине). То се види и из негативне стопе миграционог салда у овом периоду. Промене у имиграционој политици у земљама имиграције, после економске кризе седамдесетих година, условиле су касније значајно смањивање броја грађана на раду у иностранству. Од 2.750 или $2,3 \%$ од укупног становништва Општине, које је било на привременом раду у иностранству 1991. године, највећи број налазио се у Немачкој (Универзитет у Новом Саду, ПМФ-Институт за географију,1996). Број Панчеваца у иностранству 2002. године износио је 4.776 лица, што указује да је велики број становника Панчева напустио земљу у време економске и политичке кризе деведесетих Чак $30,4 \%$ становништва Иванова налази се на раду у иностранству (Р3С, 2004B).

Аутохтоно и мигрантско становништво - Панчево спада у групу изразито миграционих општина Војводине. Са преко 58\% досељеног становништва1961. године, Панчево је било једина банатска општина, поред Сечња, која је у то време имала више од половине досељеног становништва. Атрактивност Панчева за досељенике резултат је његовог привредног развоја, али и повољног геосаобраћајног положаја у односу на Београд. Највећи број досељеног становништва у укупном Општина је имала 1971. године у периоду интензивног индустријског развоја. Удео аутохтоног становништва Општине на рачун досељеног повећава се од седамдесетих година, достигавши 2002. године однос $50,1 \%$ на према $49,9 \%$ у корист миграната.

У периоду 1961-2002. година удео аутохтоног становништва највише је повећан у приградским насељима Јабуци, Качареву и Старчеву. Према Попису становништва из 1961. године, од укупног становништва у Јабуци досељено је било 65,5\%, у Качареву $73,8 \%$ и Старчеву $54,8 \%$. У поређењу са Војводином као већом просторном целином, где у последњих педесет година удео досељеног становништва у укупном не прелази половину, у општини Панчево удео досељеника у укупном становништву константно прелази 50\%. Општина је примила већи број досељеника и у поређењу са припадајућим 
Јужно-банатским округом. Највише аутохтоног становништва на нивоу Општине имају насеља Долово и Иваново која нису била обухваћена колонизацијом у периоду 19461947. година, а најмање приградско насеље Старчево и градски центар. Подаци од пре тридесет година показују да су и у то време највећи удео аутохтоног становништва у укупном имала иста два насеља као и 2002. године, а са уделом аутохтоног становништва мањим од $40 \%$, поред Старчева и Панчева, истицала су се колонистичка насеља Глогоњ, Јабука и Качарево.

Табела 16. Аутохтоно и мигрантско становништво

\begin{tabular}{|c|c|c|c|c|c|c|}
\hline Територија & $\begin{array}{c}\text { Година } \\
\text { пописа }\end{array}$ & $\begin{array}{c}\text { Укупно } \\
\text { становништво }\end{array}$ & Аутохтоно & $\%$ & Мигрантско & $\%$ \\
\hline \multirow{5}{*}{ војводина } & 1961. & 1.854 .965 & 1.007 .149 & 54,3 & 847.816 & 45,7 \\
\cline { 2 - 7 } & 1971. & 1.952 .533 & 1.041 .911 & 53,4 & 910.622 & 46,6 \\
\cline { 2 - 7 } & 1991. & 2.013 .889 & 1.098 .960 & 54,6 & 914.929 & 45,4 \\
\cline { 2 - 7 } & 2002. & 2.031 .992 & 1.078 .799 & 53,1 & 953.193 & 46,9 \\
\cline { 2 - 7 } & 2002. & 616.202 & 354.385 & 57,5 & 261.817 & 42,5 \\
\hline \multirow{4}{*}{$\begin{array}{l}\text { Општина } \\
\text { Панчево }\end{array}$} & 1961. & 99.853 & 41.806 & 41,9 & 58.047 & 58,1 \\
\cline { 2 - 7 } & 1971. & 110.780 & 44.852 & 40,5 & 65.928 & 59,5 \\
\cline { 2 - 7 } & 1991. & 125.261 & 60.010 & 47,9 & 65.251 & 52,1 \\
\cline { 2 - 7 } & 2002. & 127.162 & 63.441 & 49,9 & 63.721 & 50,1 \\
\hline
\end{tabular}

Извор података:С 3С, 1966;С ЗС, 1973а;Р3С, 19926; Р3С, 2004в.

Када се посматра популација града Панчева, 1948 . године $40,3 \%$ становништва било је рођено у Панчеву. На основу удела аутохтоног у укупном становништву видно је да се досељавање у Панчево појачало након 1948. године (Илић Ј.,1967). Град Панчево је 1961. године имао $34,4 \%$ аутохтоног становништва. Године 2002. у граду Панчеву било је $46,9 \%$ аутохтоног становништва.

Табела 17. Аутохтоно и мигрантско становништво 2002. године

\begin{tabular}{|l|c|c|c|c|c|}
\hline \multicolumn{1}{|c|}{ Територија } & $\begin{array}{c}\text { Укупно } \\
\text { становништво }\end{array}$ & Аутохтоно & $\%$ & Мигрантско & $\%$ \\
\hline Банатски Брестовац & 3517 & 2017 & 57,4 & 1500 & 42,6 \\
\hline Банатско Ново Село & 7345 & 4029 & 54,9 & 3316 & 45,1 \\
\hline Глогоњ & 3178 & 1660 & 52,2 & 1518 & 47,8 \\
\hline Долово & 6835 & 4082 & 59,7 & 2753 & 40,3 \\
\hline Иваново & 1131 & 710 & 62,8 & 421 & 37,2 \\
\hline Јабука & 6312 & 3649 & 57,8 & 2663 & 42,2 \\
\hline Качарево & 7624 & 4293 & 56,3 & 3331 & 43,7 \\
\hline Омољица & 6518 & 3436 & 52,7 & 3082 & 47,3 \\
\hline Панчево & 77.087 & 36.172 & 46,9 & 40.915 & 53,1 \\
\hline Старчево & 7615 & 3393 & 44,6 & 4222 & 55,4 \\
\hline Општина Панчево & 127.162 & 63.441 & 49,9 & 63.721 & 50,1 \\
\hline
\end{tabular}

Савремене тенденције повеһања удела аутохтоног становништва у укупном запажају се како у граду тако и осталим насељима. И поред тога, град Панчево као и остала насеља Општине имају већи удео мигрантског становништва у укупном у односу на одговарајуһи тип насеља у Војводини као целини. Из односа аутохтоног и мигрантског становништва евидентно је смањење обима миграционих кретања у односу период интензивне идустријализације шездесетих и седамдесетих година прошлог века. Без миграционих токова избеглица из правца бивших југословенских република у 

становништва.

Порекло досељеног становниитва-правци миграционих струја - Од укупног становништва Панчева 2002. године $7 \%$ досељено је из Хрватске, $6 \%$ из Босне и Херцеговине и $3 \%$ из Македоније (Р3С, 2006в). Пореклом из Хрватске 1961. године било је $7,5 \%$ становништва Панчева, док је $4,9 \%$ становништва било пореклом из Босне и Херцеговине. У граду Панчеву од алохтоног становништва, из осталих места панчевачке општине потицало је 7,9\% становништва (највише из Долова, Старчева и Омољице), из суседних општина $23,1 \%$ становништва, и остале Војводине $27,4 \%$ (Илић J.,1967). У Панчеву су мање изражена локална и досељавања из других општина Војводине која су специфична за Банат као целину. Међутим, промене типа миграција према месту порекла досељеника показују да се пресељавање становништва у оквиру саме Општине интензивира, док се број досељеника из других општина Војводине, који су седамдесетих година чинили $60 \%$ од укупног броја досељених, знатно смањио. Досељавање становништва са подручја бивших југословенских република, заједно са колонизацијом становништва после Другог светског рата допринело да је више од половине досељеног становништва Јабуке, Качарева и Банатског Новог Села 2002. године било пореклом из бивших југословенских република. Године 1961. 7,1\% становништва Општине било је пореклом из Македоније или 6.598 становника, од чега је око 4.500 живело у Качареву и Јабуци, као последица колонизације извршене у периоду 1946-1947. година (СЗС,1966).

Табела 18. Порекло досељеног становништва

\begin{tabular}{|c|c|c|c|c|c|c|c|c|}
\hline & \multicolumn{4}{|c|}{1971} & \multicolumn{4}{|c|}{2002} \\
\hline & \multicolumn{2}{|c|}{ Војводина } & \multicolumn{2}{|c|}{ Панчево } & \multicolumn{2}{|c|}{ Војводина } & \multicolumn{2}{|c|}{ Панчево } \\
\hline & Бpoj & $\%$ & Бpoj & $\%$ & Бpoj & $\%$ & Бpoj & $\%$ \\
\hline Укупно досељено & 910.622 & 100 & 63.721 & 100 & 953.193 & 100 & 63.721 & 100 \\
\hline \multicolumn{9}{|l|}{ Досељено из: } \\
\hline $\begin{array}{l}\text { другог места } \\
\text { исте опитине }\end{array}$ & 163.019 & 17,9 & 9.186 & 14,4 & 177.935 & 18,7 & 9.186 & 14,4 \\
\hline $\begin{array}{l}\text { друге општине } \\
\text { Војеодине }\end{array}$ & 463.921 & 50,9 & 13.411 & 21,0 & 258.297 & 27,1 & 13.411 & 21,0 \\
\hline $\begin{array}{l}\text { друге репуббиике/ } \\
\text { покрајине }\end{array}$ & 263.412 & 28,9 & 19.813 & 31,1 & 125.506 & 13,2 & 19.813 & 31,1 \\
\hline $\begin{array}{l}\text { бивших република } \\
\text { СФР] }\end{array}$ & & & 20.249 & 31,8 & 377.796 & 39,6 & 20.249 & 31,8 \\
\hline иностранства & & & 734 & 1,2 & 9.069 & 1,0 & 734 & 1,2 \\
\hline
\end{tabular}

Извор података: СЗС, 1971; Р3С,2004в; Кисошев и др., 2005.

Правци и време досељавања миграната на простор општине Панчево указују да је од становништва досељеног из бивших југословенских република највећи број досељен у периоду 1991-1995. година, а затим 1946-1960. година тј. у периоду који обухвата колонизацију. Из Централне Србије мигранти су досељени највише у периоду 1961-1970. година. Регионалне миграције најобимније су биле до седамдесетих година прошлог века, док су се локалне миграције претежно уједначено одвијале у свим временским периодима, мада са нешто обимнијим токовима у последњем периоду.

Имајући у виду да је праћење миграција према времену досељавања под утицајем смртности и поновног пресељавања становништва, наводимо податке о пореклу досељеног становништва на простор панчевачке општине у време Пописа становништва из 2002. године и према тада важећој методологији. Највише становника у Панчево је било досељено из Србије (42.410), од чега 18.243 из Централне Србије, и 1.570 са Косова и Метохије. Од бивших југословенских република највише 
становништва досељено је из Хрватске 8.382, а из затим Босне и Херцеговине 6.956, Македоније 3.967, Црне Горе 704 и Словеније 240. У последњем петогодишту пре Пописа становништва из 2002 године становништво се у Панчево највише досељавало са подручја Централне Србије, а затим локално пресељавало у оквиру саме Општине (Р3С,2006в). Када се изузме досељавање из бивших југословенских република, на чији су обим знатно деловале избегличке миграције деведесетих година, у Војводини и Банату преовладавају регионалне миграције, а у Панчеву међурегионалне миграције (досељавање са простора Централне Србије) што говори о ширем функционалном утицају Панчева. Диференцијација насеља Општине према пореклу досељеног становништва, показује као специфично приградско насеље Старчево, где је једна трећина становништва досељена са подручја исте Општине, и које је евидентно велики ancopпциони центар локалних миграната.

Табела 19. Порекло досељеног становништва Панчева (\%) 2002. године

\begin{tabular}{|c|c|c|c|c|c|}
\hline \multirow[b]{2}{*}{ Територија } & \multicolumn{5}{|c|}{ Досегено из: } \\
\hline & $\begin{array}{c}\text { исте } \\
\text { општине }\end{array}$ & $\begin{array}{c}\text { друге општине } \\
\text { Војводине }\end{array}$ & $\begin{array}{c}\text { Apyre } \\
\text { penублике/ } \\
\text { покрајине }\end{array}$ & $\begin{array}{c}\text { Gившикх } \\
\text { peny6лика } \\
\text { СФРJ }\end{array}$ & иностранства \\
\hline Б. Брестовац & 17,1 & 7,2 & 61,6 & 12,4 & 1,0 \\
\hline 5. Ново Село & 8,0 & 12,1 & 10,4 & 67,4 & 2,0 \\
\hline Tnorolt & 11,9 & 8,0 & 28,7 & 49,9 & 1,1 \\
\hline Aonoso & 11,3 & 20,0 & 52,9 & 13,1 & 2,2 \\
\hline Иваново & 52,7 & 18,5 & 17,8 & 8,1 & 2,4 \\
\hline Ja6yка & 14,6 & 7,0 & 17,6 & 59,9 & 0,8 \\
\hline Качарево & 8,1 & 8,1 & 24,2 & 57,9 & 1,1 \\
\hline Омолича & 22,4 & 6,4 & 45,2 & 24,2 & 1,3 \\
\hline Панчево & 12,7 & 27,3 & 31,7 & 26,6 & 1,1 \\
\hline Старчево & 33,5 & 7,5 & 38,6 & 19,1 & 0,9 \\
\hline Градска & 14,2 & 24,3 & 31,8 & 28,1 & 1,0 \\
\hline Oстала & 15,2 & 10,7 & 33,4 & 38,8 & 1,5 \\
\hline Општина Панчево & 14,4 & 21 & 32,2 & 30,7 & 1,2 \\
\hline
\end{tabular}

Нзвор података: Р3С,2004в.

Интересантно је размотрити миграционе везе између Београда и Панчева. Према Попису становништва из 1991. године у Београду је у то време било 89.452 досељеника из Војводине, од чега 10.591 или $12 \%$ из Панчева. Досељеника у Војводину из Београда било је 33.532 , од чега у Панчево 5.220 или $15 \%$, и то највише са Палилуле, Савског Венца и из Земуна. Следи да је привлачност Београда била двоструко већа по обиму за становништво Панчева него обрнуто, што указује на комплементарност токова дневних и дефинитивних миграција. По броју досељеника у Панчево после београдских општина следе општине Трговиште и Пирот са више од 1000 миграната, а затим Врање, Лесковац и Нови Пазар. Од војвођанских општина које су дале велики број миграната Панчеву то су суседне општине Алибунар, Опово, Ковачица и Ковин, и општина Зрењанин. Из суседних банатских општина на простор општине Панчево било је досељено 13,8\% миграната 1991. године, из Централне Србије 30,3\%, из БиХ 9,3\%, из Македоније $8,2 \%$, из Хрватске $5,8 \%$ и остале Војводине $25,7 \%$. Миграциона кретања из Панчева већином су била усмерена ка великим урбаним центрима Београду и Новом Саду. Из Панчева се становништво у највећем броју одселило у београдске општине Нови Београд, Палилулу и Вождовац, следе локална пресељавања, пресељавања у општину Ковин, а затим у Нови Сад. У Ковин се из Панчева одселило 1.200 а из Ковина доселило у Панчево око 3.500 становника. Подаци о становништву које се доселило до 1991. године, према општини полазишта, показују да је у Град Панчево највише 
досељено становништво из Војводине $39,5 \%$ а затим из Централне Србије 30,3\%. (РЗС, 1992B).

Старосио-полна структура досељеног становниитва - Подаци Пописа становништва из 2002. године о старосно-полној структури становништва у време пресељења показују да је у време досељавања у Панчево више од половине становништва било старости од 15 до 34 године. С обзиром да је у време досељења мигрантско становништво било просечно млађе од аутохтоног деловало је на успоравање процеса старења, нарочито од базе старосне пирамиде становништва Панчева. Деца до 15 година чинила су $26 \%$ у структури досељеника 2002. године. Највећи број деце до 15 година старости досельен је из општина Централне Србије. Ова пресељења вероватно су везана за школовање и близину Београда, при чему одлуку о пресељењу доносе родитељи. Деца до 15 година старости такође чине знатан удео у структури повратника из иностранства (40\%). Њихов повратак везан је за школовање или повратак родитеља у земљу. Свега $10 \%$ досељеника у време пресељења било је старије од 40 година. У структури досељеника из Хрватске и Босне и Херцеговине приметно је надпросечно учешће досељеника старијих од 40 година, што је и очекивано с обзиром да се ради претежно о избеглицама доспелим на подручје Општине у последњој деценији а имајући у виду да је за избегличке мигращије, за разлику од тзв. економских миграција, карактеристично кретање целих породица. Од укупног броја досељених на простор општине Панчево веһи број чине жене. У структури досељеног становништва 27.669 или $43,4 \%$ су мушкарци а 36.052 или $56,6 \%$ су жене. Жене доминирају у полној структури миграната који су се преселили локално или у оквиру Војводине, што се може довести у везу са женидбено-удадбеним миграцијама. Код досељених са подручја Централне Србије разлике између досељавања мушкараца и жена су најмање, мада су и разлике даље $45 \%$ на према $56 \%$ у корист жена (Р3С,2006в).

Структура досељеника према типу насеља полазишта показује да је према подащима Пописа становништва из 1961. године на простор општине Панчево мање досељено становништва из сеоских насеља у односу на припадајући регион. У општини Панчево 1961. године било је 72,8\% досељеника из сеоских насеља, 4,6\% из мешовитих и $20,7 \%$ из градских. У град Панчево досељено је $61,2 \%$ становништва из сеоских, $6,5 \%$ из мешовитих и $30,2 \%$ из градских насеља. У односу на градове у окружењу у Панчеву је у то време било мање досељеника из сеоских насеља. Веће досељавање становништва из градских насеља сматра се резултантом привлачног дејства повољне локације Панчев у односу на Београд (CDI-IDN,1970).

Графикон 2. Структура миграната према типу насеља полазишта (\%)

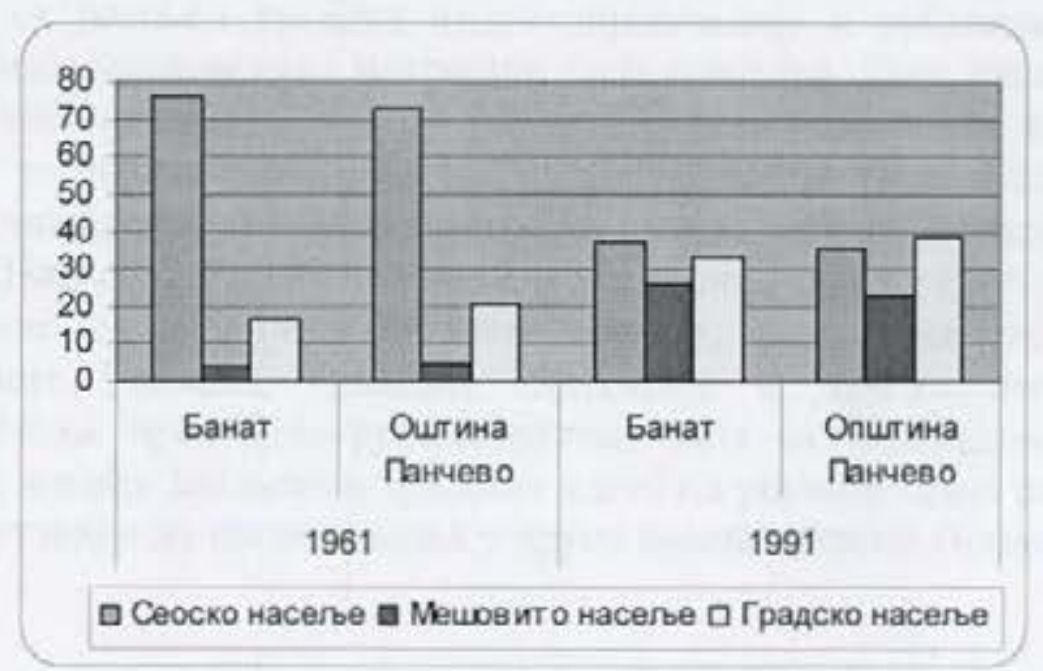

Извор података:CDI-IDN, 1970;P3C, 1992в. 
Године 1991. досељеника на простор Општине из сеоских насеља је било двоструко мање - 36\%, 23\% из мешовитих и $39 \%$ из градских насеља. У Граду је 1991. године било $27 \%$ досељених из сеоских насеља, $24 \%$ из мешовитих и $47 \%$ из градских насеља. У поређењу са Банатом као широм регионалном целином општина Панчево и даље више привлачи градско становништво (Р3С, 1992в).

У последњој пописној декади мигранте су више примила сеоска насеља Војводине, док је овај однос за Панчево у корист градских насеља. Удео миграната досељених у овом периоду у укупном броју миграната у градским насељима Панчева у односу на сеоска износио је $25,6 \%$ на према $21,2 \%$, док је овај однос на нивоу Војводине $29,7 \%$, на према $37,3 \%, 2002$. године. Ово је још једна потврда снажне привлачне апсорпционе моһи града Панчева за мигранте. Према подацима Пописа становништва из 2002 године две трећине досељеника из бивших југословенских република живи у градским насељима општине Панчево, док на нивоу Војводине ови досељеници подједнако насељавају како градска тако и сеоска насеља. Досељеници из друге општине Војводине (регионални мигранти) такође су концентрисани у градским насељима Општине, што говори о привлачности града за становништво целе Војводине. Структуру досељеног становништва у граду Панчеву прилично равномерно чине регионални мигранти, досељени из друге републике/покрајине и становници бивших југословенских република. Најмањи удео имају локални мигранти. Мигранти досељени из бивших република СФРЈ чинили су у сеоским насељима Панчева $40 \%$ од укупно пописане мигрантске популације 2002. године (Р3С,2006в).

\section{4. Развој дневних миграција као детерминанта обима и територијалног домета савремених миграционих токова дневног урбаног система Панчева}

Сагледавање досадашњег развоја, постојећег стања и перспективе развоја процеса дневних миграција урбаног система Панчева доприноси спознаји везе између процеса дневне миграције и његових узрочних фактора и последица на простору општине Панчево и шире. Правци и интензитет токова дневних миграција показују различите природне предиспозиције и токове демографског и друштвено-економског развоја насеља општине Панчево указујуһи на међузависност демографских и социоекономских промена.

Статистички подаци пописа становништва омогућавају праћење тренда дневних миграција становништва општине Панчево од 1961. године. Учешће дневних миграната радника у укупном запосленом становништву у општини Панчево константно је изнад просека за Војводину, као ширу регионалну целину, (22,7\% на према $13,2 \% 1961$. године, односно $29,6 \%$ на према $22,8 \%$ 2002. године). Развоју дневних миграција Панчева допринели су како његов повољан геосаобраћајни положај тако и привредни развој. Упоредо са јачањем процеса индустријализације и урбанизације у Панчеву развиле су се и масовније дневне миграције становништва. Везе између села и града постале су интензивније, и дошло је до прерастања веза повременог карактера између града и околине у сталне, с обзиром да “јединство места рада и становања које је карактерисало запослене у пољопривреди није нужно одвијањем процеса деаграризације" (Петровић Р., 1979). Удео дневних миграната у укупном броју радника на нивоу Општине од тада је у сталном порасту, услед целокупног друштвеноекономског развоја Панчева, снажења индустрије и других непољопривредних делатности, и јачања просторно-функционалних веза са Београдом. У последњих четрдесет година, између двадесет и тридесет одсто од укупног броја радника Општине свакодневно је путовало до посла и назад у друго насеље. Према Попису становништва 
пз 2002. године регистрован је до сада највеһи удео дневних митраната у укупном броју ранника општине Панчево $(29,6 \%)$. Да није било пораста обима дневних миграција, стопа пораста дефинитивних миграција (мисли се првенствено на исељавање становништва у потрази за запослењем) на простору Општине сигурно би се повеһала.

Када је реч о броју дневних миграната радника Општине, у односу на суседне општине и шире окружење, према Попису становништва из 1961. године по уделу нневних миграната у активном становништву $(22,7 \%)$ панчевачка општина налазила се одмах иза Ковачице. Општине Опово, Алибунар и Ковин у то време нису имале изражене дневне токове радне снаге, док је 11,7\% радника-службеника Београда учествовало у дневним миграцијама (С3С,1967). Осамдесетих година прошлог века, сразмерно својој популашионој величини и економском значају општинског центра, општина Панчево има веһи број и удео дневних миграната у активном становништву у односу на све суседне општине, осим Опова. Општина Опово са великим уделом пољопривредног становништва није могла да обезбеди запослење вишковима домаһе радне снаге који су настали током процеса деаграризације, у фази преласка са пољопривредне на индустријску производњу, и у то време имала је чак $49 \%$ дневних миграната у укупном активном становништва, а што је износило $10 \%$ од њеног укупног становништва (Р3С,2004в,РЗС,2004а). У односу на суседне општине, и 2002. године општина Панчево имала је мање учешһе дневних миграната у запосленом становништву од Опова, а веһе у односу на остале општине.

Графикон 3. Промене удела дневних митраната у запосленом становништву 1981-2002. год."

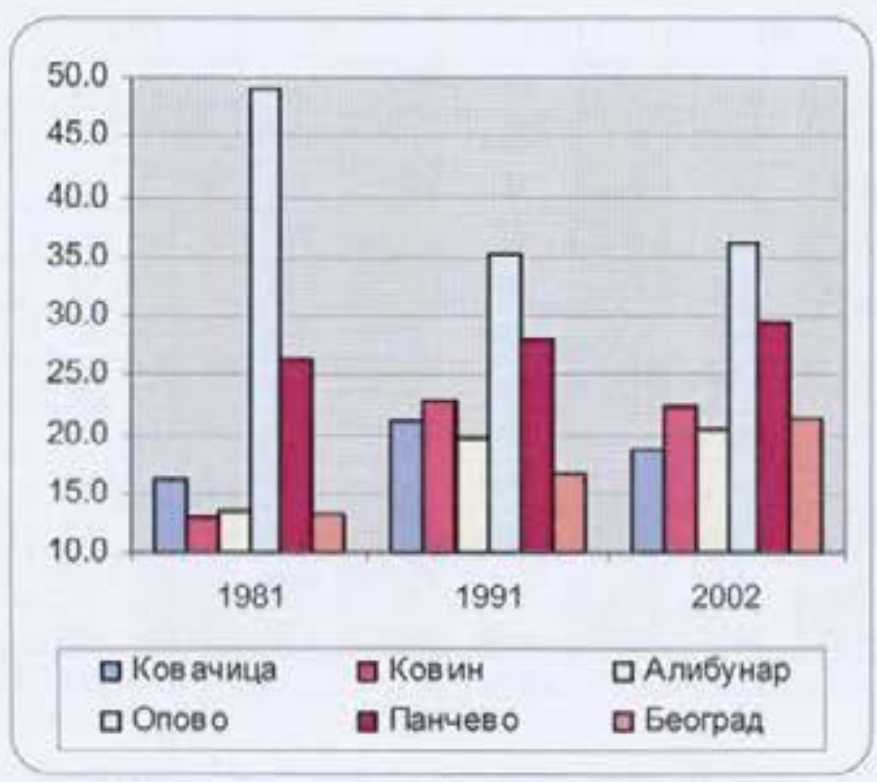

Извор података: Р3С, 2006а; Р3С, 2004a.

Године 1991. од осамнаест општина у Србији са више од 100.000 становника највећи удео дневних митраната у запосленом становништву имале су општине Панчево и Смедерево (28\%), док су највеһи удео дневних миграната у укупном становништву имале општине Крушевац $(12,2 \%)$ и Краљево $(11,8 \%)$. Године 2002 . од опитина у Србији са више од 100.000 становника највеһи удео дневних миграната у активном становништву имале су општине Панчево $(29,6 \%)$ и Палилула $(28,4 \%)$. Ово су уједно и општине са више од 10\% дневних миграната у укупном становништву 2002. године (Р3С, 2006а; Р3С,2004a). ${ }^{12}$

\footnotetext{
За 1981. и 1991. годину радници, а за 2002. годину активно становништво које обавља занимање.

Подаци су за обе пописне године дати према методологији пописа становништва 1991. године, ради уовредивости.
} 
Насеља општине Панчево карактерише различито учешће радника у дневним миграцијама током међупописних периода. Разлике у броју дневних миграната између насеља условљене су како њиховим саобраћајно-географским положајем тако и факторима демографске и економске природе. Од 1961. године највише се повећао број радника дневних миграната у насељима Старчево и Јабука. За разлику од других изузетно аграрних насеља Јабука, Старчево и Качарево још 1971. године имала су мање од половине становника запослених у пољопривреди, изузимајући општински центар. Као пример дневних миграција, у ово време, наводи се податак да је већина запослених у фабрици скроба у Јабуци $(38,2 \%)$ шездесетих година прошлог века становала у Качареву. Радници су на посао долазили возом и фабричким аутобусом (Илић Ј., 1967). И данас је Качарево заједно са Старчевом најјачи дисперзивни центар дневних миграната у Општини, после општинског центра. У последњој деценији 20. века, aпсолутан број дневних миграната на нивоу Општине, као и у већини насеља се смањује, премда удео дневних миграната у укупном броју радника расте у овом периоду у већини насеља. Смањење броја дневних миграната у већем броју насеља у периоду 1991-2002. година резултат је друштвено - економске кризе (несташица горива, нередован саобраћај и др.) у време након распада бивше Југославије, али и смањеног броја активног становништва које обавља занимање у свим насељима осим Долова у овом преиоду. Негативан миграциони салдо у Јабуци и Качареву у ово време указује на могуће пресељење одређеног броја дневних миграната у насеље рада, што је такође утицало на смањење броја дневних миграната из ових насеља.

Табела 20. Упоредни преглед броја радника који раде ван насеља становања 1961-2002. год.

\begin{tabular}{|l|c|c|c|c|c|c|c|c|c|c|}
\hline \multirow{2}{*}{ Територија } & \multicolumn{2}{|c|}{1961} & \multicolumn{2}{c|}{1971} & \multicolumn{2}{c|}{1981} & \multicolumn{2}{c|}{1991} & \multicolumn{2}{c|}{2002} \\
\cline { 2 - 13 } & Број & $\%$ & Број & $\%$ & Број & $\%$ & Број & $\%$ & Број & $\%$ \\
\hline Општина Панчево & 5575 & 22,7 & 8063 & 26,5 & 11.063 & 26,2 & 13.370 & 28,0 & 12.823 & 29,6 \\
\hline Б. Брестовац & 52 & 8,5 & 153 & 21,2 & 471 & 43,4 & 578 & 47,6 & 576 & 51,4 \\
\hline Б. Ново Село & 178 & 27,3 & 318 & 36,7 & 728 & 495 & 1086 & 40,0 & 939 & 39,0 \\
\hline Глогоњ & 62 & 17,8 & 289 & 56,2 & 606 & 66,8 & 717 & 66,7 & 606 & 65,3 \\
\hline Долово & 24 & 3,8 & 163 & 24,2 & 661 & 50,7 & 946 & 40,2 & 1039 & 43,4 \\
\hline Иваново & 20 & 8,1 & 68 & 45,6 & 112 & 42,7 & 217 & 52,5 & 177 & 52,2 \\
\hline Јабука & 445 & 45,5 & 824 & 66,2 & 1479 & 77,6 & 1684 & 74,8 & 1552 & 78,2 \\
\hline Качарево & 1088 & 53,5 & 962 & 46,7 & 1849 & 71,3 & 1943 & 70,6 & 1623 & 71,0 \\
\hline Омољица & 320 & 38,6 & 575 & 58,9 & 1309 & 72,6 & 1500 & 66,1 & 1338 & 62.4 \\
\hline Панчево & 2857 & 16,4 & 3638 & 16,8 & 1976 & 6,9 & 2595 & 8,7 & 3069 & 11,2 \\
\hline Старчево & 529 & 58,3 & 1073 & 69,9 & 1872 & 82,0 & 2104 & 74,8 & 1904 & 79,7 \\
\hline
\end{tabular}

Извор података: C3C,1967; CDI-IDN, 1970;P3C,2006а; Р3C,2007 Посебна обрала података.

Поред промена апсолутног броја радника дневних миграната о развоју дневне миграције на територији Панчева говори и удео дневних миграната у укупном броју радника на нивоу насеља. Учешһе дневних миграната у укупном броју радника као и њихов апсолутан број на нивоу насеља осцилира током посматраног периода. Више од $50 \%$ дневних миграната у укупном броју радника 1961. године имала су насеља Старчево и Качарево, док је 2002. године забележено чак седам насеља Општине у којима је више од половине радника свакодневно путовало до посла ван свог насеља становања. Када се узму у обзир сви посматрани међупописни периоди само је у насељу Банатски Брестовац удео радника дневних миграната у укупном броју радника у сталном порасту. Из малог удела дневних миграната у укупном броју радника становника општинског центра види се да је становништво претежно запослено у локалној индустрији. 
Запажа се међузависност дневних миграшија становништва са економским и лругим аспектима локалног и регионалног развоја. Шездесетих и седамдесетих година прошлог века удео дневних миграната у укупном броју радника града Панчева износио је око $15 \%$, док је од 1981. године мањи. Овај податак говори о јачању функција града чиме се смањила потреба његове радне снаге за дневним миграцијама. Поновни пораст улела дневних миграната у активном градском становништву које обавља занимање, у последњој депенији прошлог века рефлектује трансформагију економске структуре становништва из производних у услужне делатности. Шездесетих година је, према процени, око 5-6.000 људи било привремено одсутно из Панчева, а око 7.500 привремено присутно. То значи да се стално становништво града Панчева повећавало за око 2.000 лица или 3,5-4\% (Đošić D.,1970). Према подацима из 2002. године у граду је привремено присутно било 4.417 људи, а привремено одсутно 8.484 лица, односно статно становништво града се привремено смањује у токоу дана за 4.067 лица или $5,2 \%$ (Р3С.2007 Посебна обрада података). Ако посматрамо остала градска насеља видимо да је преко $70 \%$ радника Старчева, Јабуке и Качарева 2002. године обављало функцију рада ван свог насеља. Дневни мигранти чинили су чак $30 \%$ од укупног броја становника у Старчеву и Јабуци 2002. године. Преовлађивање стамбене функције у Старчеву, услед непосредне близине Панчева, утицало је да ово буде насеље са највећим уделом дневних миграната у укупном броју радника у свим посматраним међупописним периодима.

У структури радника дневних миграната општине Панчево, све до 1981, године више од половине чинили су дневни мигранти града Панчева, аналогно популационој величини општинског центра. У даљем периоду укупан број дневних миграната Општине равномерније је распоређен између већег броја насеља. Поред Панчева, издвајају се Старчево, Качарево, Јабука и Омољица као насеља која дају више од 10\% дневних миграната Општине. Популационо најмање насеље у општини, Иваново, учествује са свега 1,4\% у укупном броју радника дневних миграната општине Панчево. С обзиром на доста неповољан и изолован геосаобраһајни положај Иваново је изван функционалног подручја Панчева, те је веома мали део његове активне радне снаге укључен у дневне миграције према граду. На другом месту по малом учешһу у укупном броју радника дневних миграната Општине је насеље Банатски Брестовац.

Графикон 4. Удео појединачних насеља у укупном броју радника дневних миграната Општине (\%)

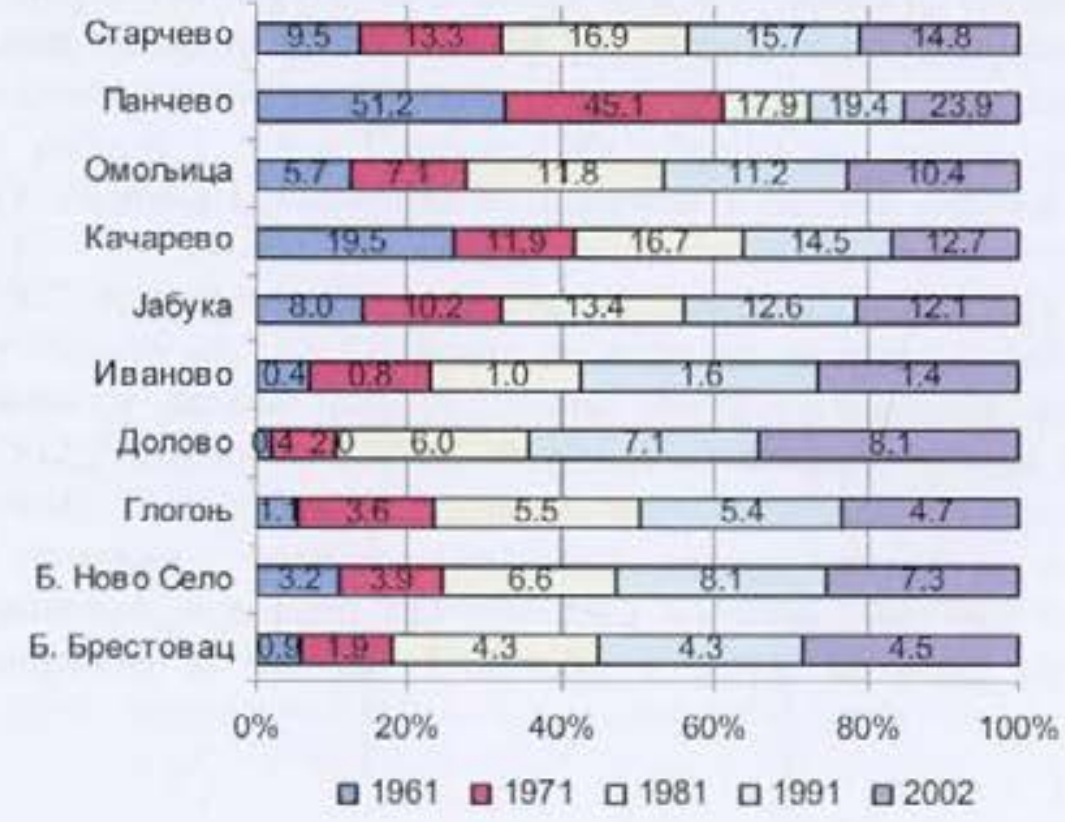

Извор података: C3C, 1967; CDI-IDN, 1970;P3C, 2006а; Р3C, 2007 Посебна обрада података. 
Анализа промена праваца дневних миграција становништва Панчева доприноси бољем разумевању дневног миграционог процеса на овом простору. На општинском нивоу 1961. године $1 / 3$ дневних миграната радника радила је у другим општинама, од чега највише у Београду. Илић истиче да су се у међуратном периоду, после изградње индустрије и Панчевачког моста створила могућност да се живи у Панчеву, а ради у Београду, што се почело све више користити (Илић Ј., 1967). Удео дневних миграната Панчева који раде у другим општинама није битније промењен временом, па је тако 2002. године $1 / 3$ радника дневних миграната Панчева $(33,2 \%)$ радила у другим општинама, од чега и даље највише у Београду (Р3С,2007 Посебна обрада података).

Ако се посматра структура дневних миграната према просторној оријентацији дневне миграције и полу, ван општине Панчево на посао путује $36 \%$ дневних миграната жена и $32 \%$ мушкараца. У структури дневних миграционих токова женске популације највећи удео жена које раде изван Општине имају насеља Глогоњ и Качарево $(23,3 \%$ и $27,6 \%$ ), што се одражава на оријентацију праваца дневних миграција укупног активног становништва ових насеља (РЗС,2007 Посебна обрада података).

Функционално дејство Београда било је и остало врло значајно за простор општине Панчево. Године 1969. 3,5 пута више Панчеваца је радило у Београду него Београђана у Панчеву. Највише је радника ишло на посао у Београд из Качарева. Интересантно је напоменути да је из Банатског Новог Села и Глогоња више било дневних миграната за Београд него за Панчево. Са простора Општине, без града Панчева, 68,6\% лица је путовало за Панчево и $31,4 \%$ за Београд. (CDI-IDN,1970). Овај однос је нешто измењен временом. Године 2002. 2,5 пута више Панчеваца је радило у Београду него Београђана у Панчеву. Као и ранијих година највише је радника ишло на посао у Београд из Качарева. Из свих насеља више је било дневних миграната за Панчево, него за Београд. Са простора Општине, без града Панчева, 69,7\% лица је путовало за Панчево и 30,3\% за Београд (Р3С,2007 Посебна обрада података).

Двострано миграционо усмерено насеље 1961. године било је Качарево. Из Качарева је тада путовало $59,5 \%$ миграната за Београд, $34,4 \%$ у Панчево и $6,1 \%$ у Ковачицу и друга места. Од укупног активног становништва Качарева $12,5 \%$ радило је у другом месту општине Панчево и $20,9 \%$ у другој општини. Јабука и Старчево спадала су у једнострано усмерена миграциона насеља, пошто је највећи број радника дневних миграната радио у једном насељу - у граду Панчеву. Из Јабуке је $89,8 \%$ миграната путовало у Панчево и 10,2\% у Београд. Од укупног активног становништва Старчева $27,4 \% 1961$. године радило је у Панчеву. Међу осталим насељима општине 1961. године једино је Омољица имала нешто већи број радника дневних миграната. Омољица је била типично једнострано усмерено центрифугално миграционо насеље са око $96 \%$ радника који су радили у граду Панчеву. Малобројна али запажена је била појава дневне миграције радника службеника из Панчева у околна насеља Општине (CDIIDN, 1970).

Године 2002. од укупно 216 дневних миграната радника који су путовали из града Панчева у околна насеља Општине највише их је ишло у Јабуку и Старчево. Качарево и Глогоњ су насеља чији су дневни мигранти радници највише усмерени према Београду (17,5\%,односно 17,3\%). Радници из осталих насеља оријентисани су према граду Панчеву, као центру рада који апсорбује преко $80 \%$ дневних миграционих токова из ових насеља. У периоду 1961-2002. година насеље са највећим уделом активног становништва које ради ван простора матичне општине било је и остало Качарево. Специфично је насеље Старчево у коме је удео укупног активног 
становништва које ради у Панчеву повећано са 27,4\% 1961. године на 48,6\% 2002. године, односно за $21,2 \%$.

Највећи број дневних миграната града Панчева 1964. године био је из приградских насеља Јабуке (16\%), Качарева и Старчева $(27 \%)$ и Омољице $(15 \%)$. Остала насеља општине била су миграторно слаба. Са територије Општине било је $88 \%$ дневних миграната који су долазили на рад у Панчево 1964. године. Најудаљенија места одакле су долазили дневни мигранти била су Уздин и Банатски Карловац (CDIIDN, 1970). Поменута насељь су и у наредном периоду главна боравишна места дневних миграната који раде у Панчеву. Дневни мигранти запослени у Панчеву већином су и 2002. године становали у истим насељима, као и пре четрдесет година али чинећи знатно мањи удео у укупној маси дневне миграције (Старчево 14,6\%, Београд, 13,4\%, Јабука $12,1 \%$, Омољица 10,3\%). Са територије Општине долазило је 70,3\% дневних миграната. 2002. године.

Када се посматрају вањски дневни мигранти - дневни мигранти који долазе са територије ван Општине 1969. године, Београд, Дебељача и Ковачица су била места полазишта највећег броја дневних миграната Панчева. Дневни мигранти долазили су из насеља добро саобраћајно повезаних са Панчевом, где је било доста колониста и пољопривредног становништва. Највише су долазили из три правца: са југоистока (Старчево, Омољица, Баваниште), са северозапада и запада (Јабука, Качарево, Дебељача и Ковачица) и југозапада (Београд) (Илић Ј.,1967). Правци најинтезивнијих токова дневних миграција остали су непромењени и 2002. године, али су се насеља полазишта нешто изменила. Београд, Баваниште и Црепаја била су места полазишта највећег броја дневних миграната Панчева са простора ван Општине. Највише дневних миграната из правца југоистока долазило је из Старчева, Омољице, Баваништа и Мраморка, са северозапада и запада (Јабука, Качарево и Црепаја) и југозапада (Београд) (Р3С,2007 Посебна обрада података).

\section{Структура дневнгх миграната}

Паралелно са променама броја дневних миграната општине Панчево и њиховог учешћа у укупном броју запослених, мењала се и структура дневних миграната. Прва фаза индустријализације у Панчеву захтевала је претежно неквалификовану радну снагу. Шездесетих година 20. века дневне мигранте на подручју Општине веһином су чинили сељаци запослени у градској индустрији и јавним службама, при чему нису били у потпуности напустили своја пољопривредна имања. Међу радницима дневним мигрантима Панчева 1964. године $13 \%$ је било висококвалификованих, $31 \%$ квалификованих, 26\% полуквалификованих и $30 \%$ неквалификованих. Код службеника -миграната било је обрнуто. Са факултетом је било чак $48 \%$, са вишом школом $27 \%$, затим са средњом стручном спремом $21 \%$ и са основном школом свега $4 \%$ дневних миграната (CDI-IDN,1970). Удео висококвалификованих дневних миграната на простору Општине се повећава. Године 2002. 16,9\% радника дневних миграната Панчева имало је више и високо образовање.

Радници запослени у секундарним делатностима доминирају по учешћу у дневним миграцијама, како у Панчеву тако и у његовим суседним општинама, али и у Србији као целини. У складу са променама у структури активног становништва Општине према делатности, током времена дошло је до промена и у структури дневних миграната према делатности. Удео дневних миграната запослених у секундарним делатностима смањио се са $60,2 \%$ 1961. године на $49,4 \% 2002$. године, док се повеһао удео дневних миграната запослених у терцијарним и квартарним делатностима (са 22,6 $\%$ на $27,9 \%$ односно са $8,8 \%$ на $17,4 \%$ ). Дневни мигранти који станују на простору општине Панчево, а свакодневно путују на посао у друго насеље Општине или у другу 
општину најмање су запослени у примарним делатностима $(3,9 \% 1961$. године односно $3,4 \% 2002$. године) (CDI-IDN, 1970,P3C,2004a). Осим Долова и града Панчева сва остала насеља Општине имају више од половине дневних миграната запослених у секундарним делатностима, што одговара структури насеља Србије према преовлађујућој делатности дневних миграната.

У структури дневних миграната према полу приметно је повећање учешћа жена са $9 \%$ 1961. године на 34,3\% 2002. године у Централној Србији, односно са $14,3 \%$ на $36,7 \%$ у Војводини (РС3, 1967). Учешће запослених жена општине Панчево у дневним миграцијама временом се такође повећава. Ове промене у складу су са све већим образовањем жена, повећањем активности жена и њиховим већим учешһем на тржишту рада, односно интеграцијом у токове радне снаге. Учешће жена радника - службеника Панчева у дневним миграцијама 1961. године износило је 13\%. У међупописном периоду 1991-2002. година, поред апсолутног броја жена дневних миграната, повећало се и учешће жена у укупној маси дневних миграната са $30,1 \%$ 1991. године на $34,3 \%$ 2002. године. Највеће учешће активних жена у дневним миграцијама имају насеља Панчево $(42,4 \%)$ и Качарево $(34,8 \%)$, а најмање Иваново $(18,1 \%)$. Највећи број жена дневних миграната ради у услужним делатностима $(63,1 \%$ жена на према $36 \%$ мушкараца). У структури дневних миграционих токова женске популације највеһи удео жена имају насеља Панчево и Банатско Ново Село ( $77 \%$ и $67,1 \%$ ), што се одражава на оријентацију праваца дневних миграција укупног активног становништва ових насеља. Планирање и имплементација програма запошљавања женске радне снаге у овим насељима допринели би задржавању радне снаге и спречили или умањили прерастање дневне у дефинитивну миграцију.

\section{Диевне миграције ученика/студената}

Поред дневних миграција активног становништва, на релацији град Панчево околина одвијају се и дневне миграције ученика и студената. Према подацима Пописа становништва из 2002. године у Србији, општина Панчево има укупно 18.690 дневних миграната, од чега 12.823 радника и 5.876 ученика/студената. Највећи број дневних миграната имају насеља Панчево и Старчево. У структури дневних миграната радници чине највећи удео у приградским насељима Јабука и Старчево, док највећи удео ученика/студената имају токови дневних миграција из насеља Банатско Ново Село и Банатски Брестовац.

Панчево је школске 1969/1970 године имало 6 средњих школа и два школска центра за школовање стручне радне снаге. Од укупног броја ученика средњих школа $50,2 \%$ је било из Панчева, $11,1 \%$ из приградских и $12 \%$ из сеоских насеља. Од $26,7 \%$ ђака са боравком ван Општине $6,2 \%$ је било из општине Алибунар, 5,2\% из Ковачице, $8,1 \%$ из Ковина и из Опова $2,1 \%$. На суседне банатске општине долазило је преко једне петине ђака указујући да је Панчево било врло значајан школски центар за читав југозападни Банат (Илић J.,1967). Од укупног броја ученика осам средњих школа школске $2001 / 2002$ године (5.792), 3.297 или $56,9 \%$ је било из Панчева, $12,4 \%$ из приградских и 16,4\% из сеоских насеља. Од 14,2\% ђака са боравком ван Општине 1,8\% је било из општине Алибунар, 5,3\% из Ковачице, и 5,5\% из Ковина. (Р3С, 2007 Посебна обрада података). Можемо закључити да се удео ђака из суседних банатских општина, који се школују у средњим школама у Панчеву знатно смањио у последњих тридесет година. 


\section{5. Промене у основним структурама становништва и домаћинстава као детерминанта обима и територијалног домета дневних миграција}

Квантитативна и квалитативна анализа људских ресурса на простору Општине веома је значајна за разумевање процеса дневних миграција становништва, с обзиром да су обим и структура становништва веома битни фактори утицаја на формирање токова дневних миграција. Свака промена ових фактора резултира променама у обиму и учешћу појединих категорија становништва у дневној миграцији. Условљеност дневних миграција обимом и структурама становништва произилази из чињенице да одређени контингенти становништва чине демографски оквир из кога се формирају токови дневних миграција. Поред биолошке структуре извршена је и анализа промена економске, образовне и етничке структуре становништва општине Панчево.

\section{Промене биолоиких структура становниитва Панчева}

Старосно-полна структура становништва Панчева одраз је развоја становништва у дужем временском периоду али и показатељ демографских потенцијала на простору Општине. Поред тога што делују на репродукцију, биолошке структуре становништва основа су за формирање функционалних контингената становништва, са бројним импликацијама за даљи демографски, друштвено-економски и социјални развој на простору Општине. Састав становништва према старости и полу има велики значај за демографска истраживања, јер условљава кретање компоненти популационе динамике, и интензитет одвијања демографских процеса међу којима су и дневне миграције становништва.

Промене старосне структуре становниитва - Старосна структура становништва општине Панчево после Другог светског рата у највећој мери је била под утицајем старосне структуре бројног досељеног становништва. С обзиром да су у старосној структури досељеника преовладавала млађа средовечна лица, у Попису становништва извршеном 1961. године, непосредно након обимнијег досељавања у Панчево, били су карактеристични релативно велики удели становништва у старосним групама 20-39 година. "Удео млађег средовечног у укупном становништву имао је највећи пораст у периоду од 1953. до 1961. године, тј. у периоду када су досељавања на подручје Панчева била највећа. Високи удели становништва у овој старосној групи представљали су значајан чинилац у погледу економског развоја града али и у погледу репродукције становништва" (CDI-IDN,1970). Деца и омладина 1961. године чинили су трећину од укупног становништва Панчева.

Сагледавање дугорочних промена у старосној структури становништва Општине указује на смањење удела младог и млађег средовечног становништва у укупном становништву, уз паралелно повећање удела старијег средовечног и старог становништва за по десет процената. Учешће младих, до 19 година старости, смањује се уелед пада наталитета, док се повећава удео старог становништва уласком у ову групу бројних досељених генерација старих до 39 година 1961. године. Висок удео старијег средовечног становништва у актуелној старосној структури становништва Панчева упуһује на интензиван процес старења становништва, премда је старосна структура становништва Општине нешто повољнија у односу на Војводину као целину, са мањим учешћем старог становништва и нешто мањом просечном старошћу становништва. С обзиром да вредност индекса старења, као показатеља односа младог и старог становништва, указује да је број младих и старих готово изједначен на простору Војводине, треба очекивати да hе се у том правцу одвијати и промене у структури становништва Панчева. Последице процеса старења становништва одразиће се 
негативно на структуру становништва, а што hе утицати на даљи развој дневних миграција на простору Општине. Ако се упореди становништво општине Панчево у односу на становништво суседних банатских општина, просечно је нешто млађе само становништво Ковина, док све остале општине имају неповољнији однос младог и старог становништва па вредност индекса старења за општину Алибунар износи чак 1,14 .

Табела 21. Велике старосне групе становништва

\begin{tabular}{|c|c|c|c|c|c|c|c|c|c|c|}
\hline $\begin{array}{l}\text { Година } \\
\text { пописа }\end{array}$ & $0-19$ & $20-39$ & $40-59$ & $60+$ & $0-19$ & $20-39$ & $40-59$ & $60+$ & $\begin{array}{l}\text { Индекс } \\
\text { старена }\end{array}$ & $\begin{array}{l}\text { Просечна } \\
\text { старост }\end{array}$ \\
\hline \multicolumn{11}{|c|}{ Општина Панчево } \\
\hline 1961 & 32.765 & 33.859 & 18.044 & 8.948 & 34,9 & 36,1 & 19,2 & 9,5 & 0,27 & 30,1 \\
\hline 2002 & 28.415 & 34.980 & 37.870 & 24.813 & 22,3 & 27,5 & 29,8 & 19,5 & 0,87 & 39,3 \\
\hline \multicolumn{10}{|c|}{ Војводина } & \\
\hline 1961 & 616.427 & 616.242 & 401.586 & 219.206 & 33,3 & 33,2 & 21,7 & 11,8 & 0,36 & 32,2 \\
\hline 2002 & 459.991 & 545.908 & 581.834 & 435.697 & 22,6 & 26,9 & 28,6 & 21,4 & 0,95 & 39,8 \\
\hline
\end{tabular}

Извор података: CDI-IDN,1970;P3C,20036.

Основне одлике промена старосне структуре становништва Панчева у последњих четрдесет година су смањење бројности контингента младог становништва и повећање контингента становништва старијег од шездесет година за готово три пута. Промене удела старосних група становништва Панчева и Војводине, кроз базни индекс 1961-2002. година, показују да је контингент становништва старог од 20-39 година у Панчеву релативно константан, са индексом пораста од 103,3 док се на нивоу Војводине смањује број лица у овој старосној групи. Контингент старијег средовечног становништва на простору Општине је двоструко повећан од 1961. године, а на нивоу Војводине у истом периоду овај контингент бележи индекс пораста у вредности од 145 . Индекс повећања броја лица старијих од 60 година за Панчево износи 277 , односно 199 за Војводину као целину. Тренд смањења броја младих и повећања броја старих у укупном становништву имаће значајне економске последице услед све мањег учешћа младих на тржишту радне снаге, а што he се одразити на обим и структуру дневних миграционих токова активног становништва.

На простору Општине евидентан је диференцијалан демографски развој општинског центра, приградских насеља и осталих насеља општине. Сеоска насеља из шире сфере утицаја Панчева имају неповољнију старосно-полну структуру становништва, док приградска насеља, услед снажног подстицајног деловања града у периоду индустријализације, одликује нешто повољнија старосно-полна структура становништва. Старосно-полна структура становништва насеља Јабука, Качарево и Старчево 2002. године одликовала су се повољнијим односом младог и старог становништва у поређењу са другим насељима Општине, па чак и општинским центром.

Према класификацији војвођанских насеља у односу на средњу старост становништва 2002. године (Ћурчић С.,2005) насеља Панчева припадају петој, шестој и седмој групи. У петој групи насеља, са просечном старошћу становништва од 42-43,9 година налазе се Банатско Ново Село и Иваново. У седмој групи насеља, са најмлађом популацијом на нивоу Општине и просечном старошћу становништва од 38-39,9 година налазе се приградска насеља Јабука, Качарево и Старчево. Популације ових насеља биле су 1971. године млађе од 30 година, што је карактерисало свега 19 насельа Војводине. За највећи број ових насеља карактеристично је било то што су примили велики број колониста. Остала насеља Општине, укључујући и општински центар налазе се у шестој групи насеља, са просечном старошћу становништва од 40-41,9 година. Емиграција младог досељеног становништва Глогоња, која је уследила 
шездесетих и седамдесетих година, условила је каснију депопулацију овог насеља (Һурчић С., 2005).

Демографски најмлађе у Општини је становништво приградских насеља чији су процес старења успориле обимне миграције, нарочито у послератном периоду, праћене израженом селективношћу миграната по старости. Актуелни демографски развој приградских насеља Панчева под утицајем је наслеђене старосно-полне структуре из 1961. године коју је одликовало велико учешће младог и досељеног млађег средовечног становништва. Код осталих насеља општине Панчево старосна структура становништва више је била под утицајем природног кретања становништва. Удео млађег средовечног становништва у насељима која нису приградска 1961. године био је нижи него у граду услед пресељавања ове категорије становништва у град и приградска насеља (Илић ј.,1967). Насељски размештај старог становништва показује да после приградских насеља најмањи удео становништва старијег од шездесет година у укупном има општински центар. У насељима Банатско Ново Село и Иваново удео старих премашује удео младих у укупном становништву.

Табела 22. Индекс старења и удео великих старосних група у укупном становништву 2002.године

\begin{tabular}{|c|c|c|c|c|c|c|c|}
\hline \multirow{2}{*}{ Територија } & \multicolumn{2}{|c|}{ Младо (0-19) } & \multicolumn{2}{|c|}{ Средовечно (20-59) } & \multicolumn{2}{|c|}{ Crapo $(60+)$} & \multirow{2}{*}{$\begin{array}{l}\text { Индекс } \\
\text { старења }\end{array}$} \\
\hline & $6 p o j$ & $\%$ & $6 p o j$ & $\%$ & 6 poj & $\%$ & \\
\hline Банатски Брестовац & 835 & 23,7 & 1881 & 53,5 & 745 & 21,2 & 0,89 \\
\hline Банатско Ново Село & 1616 & 22,0 & 3836 & 52,2 & 1838 & 25,0 & 1,14 \\
\hline Inorots & 716 & 22,5 & 1788 & 56,3 & 646 & 20,3 & 0,90 \\
\hline Долово & 1627 & 23,8 & 3607 & 52,8 & 1459 & 21,3 & 0,90 \\
\hline Иваново & 249 & 22,0 & 613 & 54,2 & 267 & 23,6 & 1,07 \\
\hline Јабука & 1478 & 23,4 & 3826 & 60,6 & 988 & 15,7 & 0,67 \\
\hline Качарево. & 1754 & 23,0 & 4410 & 57,8 & 1434 & 18,8 & 0,82 \\
\hline Омољица & 1463 & 22,4 & 3675 & 56,4 & 1293 & 19,8 & 0,88 \\
\hline Панчево & 16.836 & 21,8 & 44.921 & 58,3 & 14.703 & 19,1 & 0,87 \\
\hline Старчево & 1841 & 24,2 & 4293 & 56,4 & 1440 & 18,9 & 0,78 \\
\hline Градска & 20.431 & 22,1 & 53.624 & 58,1 & 17.577 & 19,0 & 0,86 \\
\hline Octana & 7984 & 22,9 & 19.226 & 55,2 & 7236 & 20,8 & 0,91 \\
\hline Опитина Панчево & 28.415 & 22,3 & 72850 & 57,3 & 24.813 & 19,5 & 0,87 \\
\hline Банат & 616.202 & 22,5 & 339.591 & 55,1 & 135.114 & 21,9 & 0,97 \\
\hline Војеодина & 459.991 & 22,6 & 1.127 .742 & 55,5 & 435.697 & 21,4 & 0,95 \\
\hline
\end{tabular}

Извор података: Р3С,20036.

На формирање и промене старосно-полне структуре становништва појединачних насеља Општине, поред природне и миграционе компоненте популационе динамике деловала је и структура становништва према националности. Диференцијацијама у старосно-полној структури становништва на нивоу насеља допринеле су карактеристике природног кретања по националности. Примера ради, Иваново са $40 \%$ мађарског и $28 \%$ становништва бугарске националности има најстарије становништво у Општини према свим показатељима демографске старости. Просечна старост Бугара 2002. године у Панчеву износила је преко 45 година, а Мађара 43,2 године (Р3С, 2003в). Популација Иванова услед израженог процеса старења становништва има и највећи удео жена у становништву, у поређењу са осталим насељима Општине. На другом месту у Општини према показатељима демографског старења налази се Банатско Ново Село, у коме трећину чини становништво румунске националности. Мађари и Румуни су још седамдесетих година били етничке групе у Војводини са најнижим природним прираштајем (Петровић Р.,1979). Банатско Ново Село се још 1948. године налазило 
мећу педесет насеља Војводине са највећом просечном старошћу становништва. Три детвртине насеља у Банату са просечном старошћу популашија од 34-35.9 година 1948. године била су настањена Румунима или Мађарима, као што је то случај и са Банатским Новим Селом (Ћурчић C., 2005). У приградским насељима Јабуци и Качареву на формирање старосно-полне структуре становништва, поред високог учешһа лица у репродуктивном периоду у структури колониста, битно је деловала и структура досељеног становништва по нащионалности. Македонце, досељене у великом броју у ова насеља после Другог светског рата, одликовале су високе стопе природног прираштаја шездесетих и седамдесетих година прошлог века у Србији.

Године 1961. у структури становништва Општине према петогодишњим групама старости, као резултат деловања високог наталитета и досељавања на старосну структуру, најбројније су биле децја група од 5-9 година старости и група становништва од 25-29 година старости. Beh 1971. године облик старосне пирамиде становништва Панчева се мења. База пирамиде се благо сужава и максималну ширину достиже код старосне групе 15-19 година. Неусаглашеност старосних група у пописима становништва отежава анализу поређења становништва по петогодишњим групама старости за становништво старије од 65 година. У попису становништва из 1961. године последња старосна група је становништво старо 65 година и више, а у попису 1971. године становништво старо 75 година и више.

Графикон 5. Старосна пирамида становништва општине Панчево 1971. голине

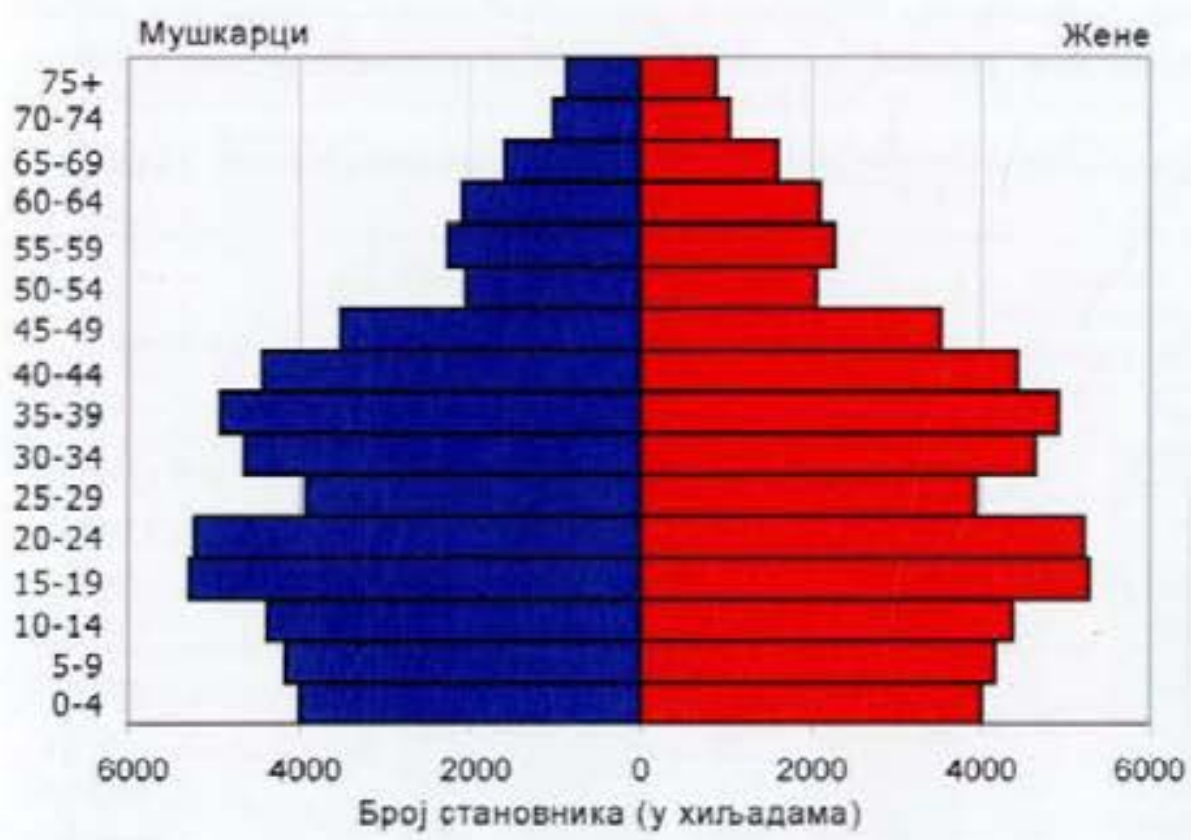

Године 2002. основа пирамиде је врло сужена, услед деловања ниског и опадајућег наталитета на старосну структуру, забележеног током 1980-их и 1990-их година прошлог века. Старосна структура становништва Панчева из 2002. године има елементе регресивног типа са уделом деде мањим од удела одраслих. Од најмлађе старосне групе многобројније су све петогодишње старосне групе до старости 70-74 године. Своју максималну ширину пирамида достиже код старосне групе 45-49 година, односно лица рођених у тзв. бејби бум периоду након Другог светског рата. Од старосне групе 65-69 година лева страна пирамиде има мању ширину 360 краћег очекиваног животног века мушког становништва. 
Графикон 6. Старосна пирамида становништва општине Панчево 2002. године

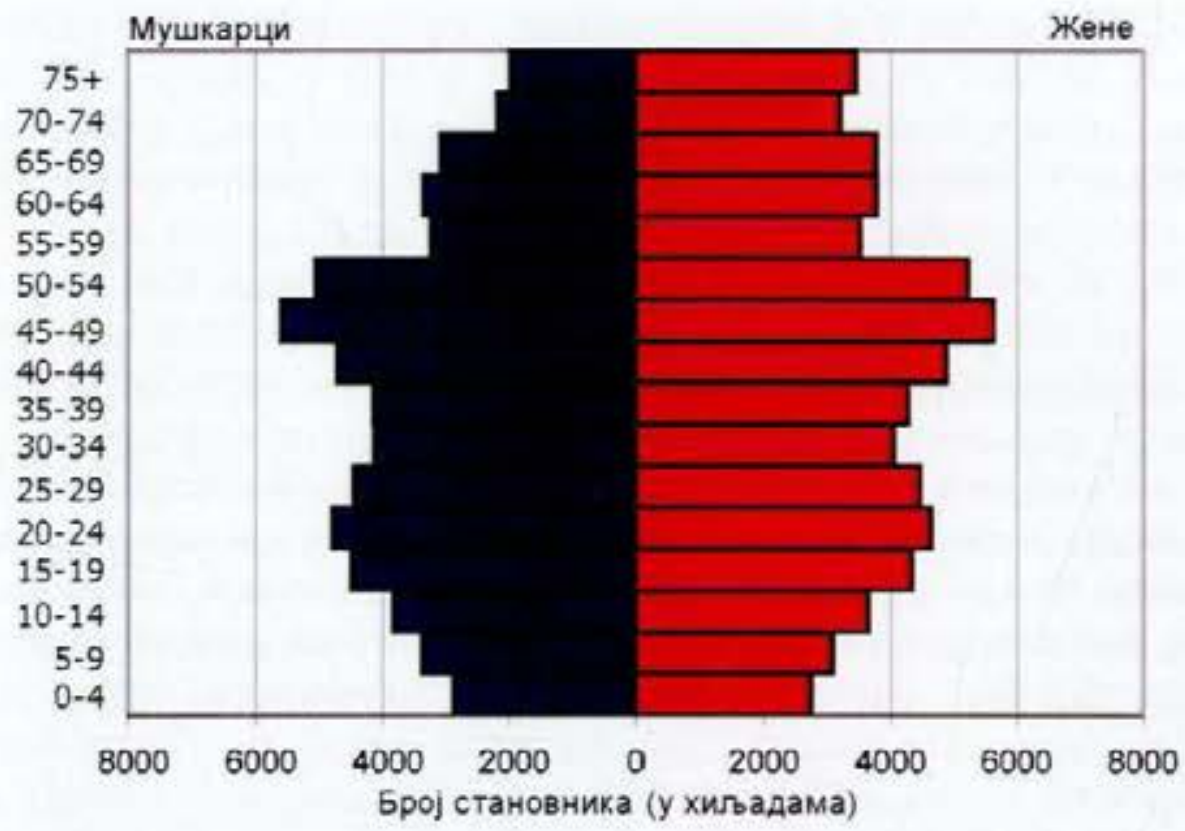

Промене старосно-полних функционалних контингената - Промене у обиму и саставу функционалних контингената становништва одражавају се на развој Општине како у демографском, тако и у привредном погледу. Од величине и структуре контингента радно способног становништва и његовог насељског размештаја, као и размештаја у односу на привредне објекте директно зависе токови дневног кретања paдне снаге.

Табела 23. Важнији старосни функшионални контингенти 2002. године

\begin{tabular}{|c|c|c|c|c|c|c|}
\hline \multirow[t]{2}{*}{ Територија } & \multicolumn{2}{|c|}{$\begin{array}{c}\text { Предшколски } \\
\text { континтент } \\
(0-7)\end{array}$} & \multicolumn{2}{|c|}{$\begin{array}{c}\text { Женоко } \\
\text { Фертилно } \\
\text { становниитво } \\
(15-49)\end{array}$} & \multicolumn{2}{|c|}{$\begin{array}{c}\text { Старачки } \\
\text { контингент } \\
\text { (75+roдина) }\end{array}$} \\
\hline & Бpoj & $\%$ & Epoj & $\%$ & Бpoj & $\%$ \\
\hline Банатски Брестовац & 219 & 6,2 & 863 & 24,5 & 200 & 5,7 \\
\hline 5. Ново Село & 433 & 5,9 & 1652 & 22,5 & 463 & 6,3 \\
\hline Tnorols & 198 & 6,2 & 762 & 24 & 174 & 5,5 \\
\hline Долово & 491 & 7,2 & 1572 & 23 & 370 & 5,4 \\
\hline Иваново & 56 & 5,0 & 249 & 17,7 & 78 & 6,9 \\
\hline Јабука & 422 & 6,7 & 1614 & 25,6 & 247 & 3,9 \\
\hline Качарево & 513 & 6,7 & 1926 & 25,3 & 301 & 3,9 \\
\hline Омољица & 416 & 6,4 & 1598 & 24,5 & 305 & 4,7 \\
\hline Панчево & 4779 & 6,2 & 20.240 & 26,3 & 3020 & 3,9 \\
\hline Старчево & 560 & 7,4 & 1858 & 24,4 & 274 & 3,6 \\
\hline Градска & 5852 & 6,3 & 24.024 & 26 & 3595 & 3,9 \\
\hline Ocrana & 2235 & 6,4 & 8310 & 23,9 & 1837 & 5,3 \\
\hline Општина Панчево & 8087 & 6,4 & 32.334 & 25,4 & 5432 & 4,3 \\
\hline Војводина & 134.600 & 6,6 & 496.596 & 24,4 & 99.778 & 4,9 \\
\hline
\end{tabular}

Предиколски контингент (0-6 година) - Контингент предшколског етановништва, у највећој мери зависан од наталитета, посредно утиче на већу или мању радну активност жена и њихово учешће у токовима дневних миграција. Предшколски контингент Општине 1961. године чинило је 11.740 деце, а што је износило $12,5 \%$ од Укупног становништва. Од тога је у грапу било 5.532 детета, а што је чинило $11,9 \%$ Укупног градског становништва. Приградска насеља (Јабука, Качарево и Старчево) 
имала су највећи удео деце предшколског узраста у укупном становништву. Укупно 2.668 предшколске деце чинило је 14,9\% становништва ових насеља (CDI-IDN,1970). Број предшколске деце на простору Општине смањен је у периоду 1961-2002. година за преко 3.600 деце, а њихов удео у укупном становништву смањен је за половину. У Општини је 2002. године живело 8.087 деце предшколског узраста, што је износило $6,4 \%$ становништва и мање је од просека за ниво Војводине. У граду је било 4.779 предшколске деце, или 6,2\% од укупног становништва, док приградска насеља и даље имају већи удео овог контингента у укупном становништву, те са $6,9 \%$ предшколске деце ова насеља задржавају особеност простора са већим уделом деце у укупној популацији која их је одликовала и шездесетих година прошлог века. С обзиром на показатеље природног кретања становништва у наредном периоду може се очекивати даље смањење предошколског контингента, што ће утицати на смањен обим дивергентних дневних миграција ученика и студената у годинама које ће уследити.

Контингент женског фертилног становниитва (15-49 година) - Женско фертилно становништво, нарочито оно у оптималном репродуктивном добу, изузетно је значајно за ниво наталитета. На простору општине Панчево овај контингент континуирано чини око једне четвртине од укупног становништва, док је према последњем Попису становништва из 2002. године на нивоу Војводине контингент женског фертилног становништва смањен испод ове вредности. Према уделу који фертилни контингент чини у укупном становништву општина Панчево налази се на на четвртом месту у Војводини, после Новог Сада, Темерина и Старе Пазове. Удео фертилног у укупном женском становништву Панчева, у последњих четрдесет година, се благо смањује и поред забележеног повећања бројности овог становништва. Разлози су првенствено у израженом процесу старења становништва, који је услед разлика у смртности становништва према полу резултирао великим бројем жена преко 75 година старости на простору Општине. Од шездесетих година прошлог века жене у фертилном периоду константно имају нешто већи удео у женском становништву у граду у односу на општински просек. Број женског фертилног становништва у оптималном репродуктивном добу (20-34 године) релативно је стабилан на нивоу Општине. Године 1961. године у овој старосној групи било је 13.040 жена а 2002. године 13.180 жена. Међутим, услед процеса старења становништва удео ове групе у укупном женском фертилном становништву смањен је са $52,7 \%$ на 20,2\% у периоду 1961 -2002. година. На основу неповољне старосне структуре фертилног контингента, као једног од фактора који утичу на обим рађања, може се очекивати даље смањивање наталитета на простору Општине и последично фертилног контингента, али и контингента ученика и студената дневних миграната. Најповољнија старосна структура женског фертилног контингента је у Банатском Новом Селу.

Контингент старог становниитва (60 и виие година) - Као потврда интензивног одвијања процеса демографског старења становништва Панчева, и Војводине у целини јесте континуирано повећање контингента старог становништва. Удео становништва старијег од 60 година у укупном становништву Општине повеһан је ca $9,5 \%$ 1961. године, на 19,5\% 2002. године, док је број лица старијих од 75 година у периоду 1971-2002. година удвостручен. Најинтензивније промене у кретању броја становника старијих од 75 година остварене су у насељима Иваново и Банатски Брестовац где је удео ове старосне групе у укупном становништву повећан $3 а$ 5\% односно $3,7 \%$. Због релативно повољније наслеђене старосне структуре становништва Панчево је 2002, године имало нешто мањи удео старог становништва у укупном у односу на просек Војводине, као што је то био случај и ранијих пописних година.

Контингент радио способног становниитва (муико: 15-64 и женско: 15-59 година) - Обим и структура контингента радно способног становништва одражава се на 
активност становништва у привреди, и обим и правце дневних миграција активног становништва које обавља занимање. Овај контингент становништва чини демографски оквир из кога се формира активно становништво. Панчево се налази међу десет општина Србије са највећим уделом радно способног становништва у укупном. На простору регионалне целине Баната удео радног контингента стагнира у последњој деценији, са вредношћу $64,5 \%$ у укупном становништву 1991. и 2002. године. Суседне банатске општине у односу на Панчево $(66,9 \%)$ имају мањи удео радно способног становништва у укупном, који се креће од $63,4 \%$ за Ковин до $60,5 \%$ за Алибунар (Р3C,2003б). Анализа промена величине радног контингента на простору Општине показује да се, за разлику од нивоа Војводине где је у претходне две деценије регистровано смањење удела радног контингента у укупном становништву, удео радног контингента у укупном становништву Панчева након смањења у периоду 1981-1991. година поново повећао у последњем међупописном периоду. Томе је у највећој мери допринео механички прилив становништва на простор општине Панчево.

Табела 24. Радни контингент становништва према полу 2002. године

\begin{tabular}{|c|c|c|c|c|c|c|c|c|c|}
\hline \multirow[t]{2}{*}{ Територија } & \multicolumn{3}{|c|}{$\begin{array}{c}\text { Радни } \\
\text { контингент }\end{array}$} & \multicolumn{3}{|c|}{$\begin{array}{l}\text { Удео радног контингента } \\
\text { у укупном становништеу }\end{array}$} & \multicolumn{3}{|c|}{$\begin{array}{l}\text { Crona искоришћености } \\
\text { радног контингента }\end{array}$} \\
\hline & Укупіно & $M(15-64)$ & ж(15-59) & Укугпно & $M$ & Ж & Укупно & $M$ & ж \\
\hline 5. Брестовац & 2246 & 1211 & 1035 & 63,9 & 69,8 & 58,1 & 71,6 & 81,3 & 60,2 \\
\hline 5. Hono Ceno & 4528 & 2422 & 2106 & 61,6 & 67,4 & 56,2 & 74,0 & 85,3 & 61,1 \\
\hline Гnorols & 2129 & 1168 & 961 & 67,0 & 72,5 & 61,3 & 67,1 & 80,1 & 51,4 \\
\hline Долово & 4214 & 2248 & 1966 & 61,7 & 66,3 & 57,1 & 72,3 & 87,6 & 54,7 \\
\hline Иеаново & 726 & 394 & 332 & 65,4 & 71,6 & 57,1 & 66,7 & 84,5 & 45,5 \\
\hline Ja6yka & 4442 & 2408 & 2034 & 70,4 & 74,6 & 65,9 & 67,7 & 75,3 & 58,8 \\
\hline Качарево & 5122 & 2682 & 2440 & 67,2 & 71,6 & 62,9 & 65,9 & 76,1 & 54,7 \\
\hline Oмолича & 4330 & 2326 & 2004 & 66,4 & 71,4 & 61,5 & 70,2 & 80,4 & 58,4 \\
\hline Панчево & 52220 & 26349 & 25871 & 67,7 & 71,6 & 64,2 & 69,5 & 74,6 & 64,4 \\
\hline Старчево & 5079 & 2737 & 2342 & 66,7 & 71 & 62,3 & 68,6 & 77,3 & 58,5 \\
\hline Градска & 62421 & 31768 & 30653 & 67,6 & 71,5 & 64 & 69,2 & 75,0 & 63,2 \\
\hline Octana & 22615 & 12177 & 10438 & 64,9 & 70,1 & 59,7 & 70,6 & 81,9 & 57,4 \\
\hline Oпитина Панчево & 85036 & 43945 & 41091 & 66,9 & 71,1 & 62,8 & 69,5 & 76,9 & 61,7 \\
\hline Војеодина & 1320694 & 689589 & 631105 & 65,0 & 70 & 60,3 & 69,1 & 76,9 & 60,6 \\
\hline
\end{tabular}

Напомена: За 1971. н 1991. становништво у земљи, а за 2002. становништво у земљи и лица на ралу у иностранству до једне године ("нови" концепт). Извор података: Р3С, 20036.

Индекс функционалне зависности (вредност 0,73) показује да је економска оптерећеност становништва у радном добу издржавањем контингента младог и старог становништва за општину Панчево међу најмањим у Србији. Године 2002. са уделом радног контингента у укупном становништву изнад општинског просека истичу се приградска насеља Јабука и Качарево и градски центар. У односу на 1961. годину удео становништва у радном периоду живота у укупном, на нивоу Општине, повећан је за $3 \%$ (са $63,8 \%$ на $66,9 \%$ ), а у приградским насельма чак за $8 \%$. Временом се мењала и структура радног контингента према полу. Удео радно способних жена у укупном женском становништву на нивоу Општине незнатно је смањен, док је удео мушкараца старих 15-64 године у укупном мушком становништву повећан за 5\% у периоду 19612002. година (СЗС,1965a,Р3С,20036). Искоришћеност радног контингента Општине износи $70 \%$. Највећа вредност стопе искоришћености радног контингента становништва од $75 \%$ је у Банатском Новом Селу.

Промене полие структуре становниитва - На подручју општине Панчево изражена је тенденција опадања стопе маскулинитета становништва од 1948. године. 
Смањивање стопе маскулинитета на нивоу Општине у сагласности је са променама у полној структури војвођанског становништва. Повећање бројности женске популације Панчева, приметно у структури становништва према полу, у великој мери је резултат разлика у просечном животном веку мушкараца и жена. И поред тога, запажа се континуираност већих вредности стопе маскулинитета становништва Панчева у односу на војвођански просек. Томе су допринеле миграције мушког становништва у потрази за запослењем у панчевачкој привреди, а нарочито након Другог светског рата. Стопа маскулинитета 2002. године износила је 944,6 промила за становништво Општине, односно 941 промил за становништво Војводине. Највеће разлике у полној структури становништва Панчева, у поређењу са полном структуром Војводине забележене су 1961. године, након обимнијих досељавања на простор Општине, када је однос стопа маскулинитета војвођанског становништва и становништва Панчева износио 949 \%о на према 983 \%. У старосној групи од 25-29 година старости овај однос био је 967 према 1082 промила. "Код колонистичког становништва у банатским насељима маскулинитет је био виши од просека за Војводину. Такође, у раздобљу 1953-1960. година позитиван миграциони салдо у Војводини посебно је био изражен код мушког становништва. Економски мотиви пресељавања су били доминантни и они су, по правилу, у првој фази више покретали мушко него женско становништво" (Һурчић С.,2005). Један од фактора који утиче на разлике у полној структури на простору општине Панчево у односу на просек за Војводину као и између појединачних насеља Општине, јесу диференцијалне старосне структуре становништва ових простора. У насељима која према показатељима демографске старости имају старије становништво више је изражен процес феминизације становништва, као резултат краһег очекиваног трајања живота мушког становништва. Становништво Општине, будући да је нешто млађе од просека за Војводину према показатељима демографске старости, има и мањи удео жена у укупној популацији у односу на војвођански просек. Стопа маскулинитета становништва Панчева, иако виша у односу на просек за Војводину нижа је у односу на вредности за Банат и суседне банатске општине. Вредности стопе маскулинитета за становништво ових општина кретале су се 2002 . године од 954,4 промила за Алибунар до 985,9 промила за Ковачицу. Стрктура становништва општине Ковачица према полу одражава се на токове дневних миграција активног становништва према Панчеву. Ковачица је, после Београда, највећи дисперивни центар активних дневних миграната на простор Панчева, који по структури привреде привлачи мушку радну снагу.

Категоризација насеља Војводине по стопама маскулинитета према Ћурчићу (Ћурчиһ С.,2005) показује да је 1961. године половина насеља Панчева била у најбројнијој петој групи насеља Војводине, са стопама маскулинитета у распону од 950999 промила. Чак 45,8\% насеља Баната припадало је овој групи. Банатско Ново Село са стопом маскулинитета испод 950\% припадало је шестој групи насеља, а Иваново, Качарево и Омољица трећој групи. У другој групи насеља са стопом маскулинитета преко $1100 \%$, налазила се Јабука, као колонистичко насеље у близини великог града са експанзивном привредом. Јабука је била међу шеснаест насеља Војводине и осам насеља Баната са највећим вредностима стопе маскулинитета 1961. године. Насеља Војводине са високим стопама маскулинитета 1961. године у највећем броју су била мала села. Изузетак је једино приградско насеље Јабука, које је у овој групи било 1961. и 1971. године. Године 2002. град Панчево, са стопом маскулинитета од $914 \%$ налазио ce у шестој групи насеља Војводине категорисаних према вредностима овог показатеља. У петој групи налазило се шест насеља Панчева, и у трећој групи три насеља са стопом маскулинитета већом од 1000 промила (Глогоњ, Јабука и Старчево) (Ћурчић C., 2005). Вредност стопе маскулинитета на нивоу Општине као и у највећем броју насеља се смањује, као последица старења становништва. Повећање удела 
мушког становништва у укупном у последњих четрдесет година имају само насеља Глогоњ и Старчево.

Када је реч о полној структури становништва у граду удео мушког становништва се постепено смањује. Панчево се 1961. године налазило међу десет градова Војводине са највећим вредностима стопе маскулинитета. Стопа маскулинитета износила је $971 \%$. На формирање биолошке структуре становништва града Панчева поред природне компоненте значајније су деловали миграциони процеси. Као последица досељавања у општински центар вишкови мушког становништва били су најизраженији у ово време код старосних група 15-19 и 25-29.

Табела 25. Распон стопа маскулинитета током периода 1971-2002. год.

\begin{tabular}{|c|c|c|c|c|c|c|c|c|c|c|c|c|}
\hline \multirow{3}{*}{ Територија } & \multicolumn{6}{|c|}{1971} & \multicolumn{6}{|c|}{2002} \\
\hline & \multirow{2}{*}{ Укупно } & \multirow{2}{*}{$\begin{array}{c}\text { Мушко } \\
\text { Број } \\
\end{array}$} & \multirow[b]{2}{*}{$\%$} & \multicolumn{2}{|c|}{ Женоко } & \multirow{2}{*}{$\begin{array}{l}\text { Crona } \\
\text { Mack. }\end{array}$} & \multirow{2}{*}{ Укупно } & \multicolumn{2}{|c|}{ Мушко } & \multicolumn{2}{|c|}{ Женско } & \multirow{2}{*}{$\begin{array}{l}\text { Crona } \\
\text { Mack. }\end{array}$} \\
\hline & & & & Бpoj & $\%$ & & & Бpoj & $\%$ & Бpoj & $\%$ & \\
\hline 5. Брестовац & 3809 & 1879 & 49,3 & 1930 & 50,7 & 973,6 & 3517 & 1735 & 49,3 & 1782 & 50,7 & 973,6 \\
\hline 5. Hoso Ceno & 7872 & 3797 & 48,2 & 4075 & 51,8 & 931,8 & 7345 & 3595 & 48,9 & 3750 & 51,1 & 958,7 \\
\hline Tnorolts & 3257 & 1636 & 50,2 & 1621 & 49,8 & 1009,3 & 3178 & 1611 & 50,7 & 1567 & 49,3 & 1028,1 \\
\hline долово & 6582 & 3252 & 49,4 & 3330 & 50,6 & 976,6 & 6835 & 3389 & 49,6 & 3446 & 50,4 & 983,5 \\
\hline Иваново & 1893 & 971 & 51,3 & 922 & 48,7 & 1053,1 & 1131 & 550 & 48,6 & 581 & 51,4 & 946,6 \\
\hline JaGyka & 5453 & 2859 & 52,4 & 2594 & 47,6 & 1102,2 & 6312 & 3227 & 51,1 & 3085 & 48,9 & 1046,0 \\
\hline Качарево & 8088 & 4103 & 50,7 & 3985 & 49,3 & 1029,6 & 7624 & 3744 & 49,1 & 3880 & 50,9 & 964,9 \\
\hline Oмольица & 5693 & 2849 & 50 & 2844 & 50 & 1001,8 & 6518 & 3258 & 50,0 & 3260 & 50,0 & 999,4 \\
\hline Панчево & 61.588 & 30.020 & 48,7 & 31.568 & 51,3 & 947,7 & 77.087 & 36.804 & 47,7 & 40.283 & 52,3 & 913,6 \\
\hline Crapueso & 6545 & 3296 & 50,4 & 3249 & 49,6 & 1014,5 & 7615 & 3856 & 50,6 & 3759 & 49,4 & 1025,8 \\
\hline Ірадока & & & 49,1 & & 50,9 & 963,1 & 92.326 & 44.404 & 48,1 & 47.922 & 51,9 & 993,9 \\
\hline Ocrana & & & 49,8 & & 50,2 & 992,4 & 34.836 & 17.365 & 49,8 & 17.471 & 50,2 & 973,6 \\
\hline Општина & 110.780 & 54.662 & 49,3 & 56.118 & 50,7 & 974,1 & 127.162 & 61.769 & 48,6 & 65.393 & 51,4 & 944,6 \\
\hline војводина & 1.952 .533 & 951.152 & 48,7 & 1.001 .381 & 51,3 & 949,8 & 2.031 .992 & 984.942 & 48,5 & 1.047 .050 & 51,5 & 940,7 \\
\hline
\end{tabular}
Извор података: С 3С, 19736;Р3C,20036.

\section{Промене сочиоекономских структура становниитва}

Неусклађеност потреба привреде за радном снагом са постојећим контингентима радног становништва (у квантитативном и квалитативном погледу) најчешћи је узрок појаве дневних миграција активног становништва на одређеном простору. Компоненте демографског развоја и интензитет привредног развоја фактори су утицаја на актуелну територијалну дистрибуцију радне снаге на простору општине Панчево. Привредни развој снажно делује на трансформацију економске структуре становништва Панчева, која је опет значајан фактор производње и одраз привредне структуре и достигнутог степена економске развијености простора општине Панчево. Анализа промена економске структуре становништва омогућава сагледавање промене услова за одвијање дневних миграција активног становништва Панчева. Квалитативне карактеристике активног становништва у поређењу са укупним становништвом разматране су у одељку о структури становништва према образовању.

\section{Промене структуре становништва према економској активности -} Миграције су одувек битан фактор повећања броја активног становништва на простору општине Панчево. Још 1869. године мађарске власти доселиле су око 500 Бугара у Иваново ради обраде ритске земље и градње заштитног насипа поред Дунава (Универзитет у Новом Саду, ПМФ-Институт за географију, 1996). На привлачност Панчева за досељавање радне снаге касније је утицао убрзани развој панчевачке индустрије 60-их и 70-их година прошлог века. Услед досељавања радника град 
Панчево је 1971. године имао већи удео активног становништва укупном него Општина као целина.

Табела 26. Становништво према економској активности

\begin{tabular}{|l|c|c|c|c|c|c|}
\hline \multicolumn{1}{|c|}{ Територија } & Активно & $\begin{array}{c}\text { Лица са } \\
\text { личним } \\
\text { приходима }\end{array}$ & Издржавано & Активно & $\begin{array}{c}\text { Лица са } \\
\text { личним } \\
\text { приходима }\end{array}$ & Издржавано \\
\hline \multicolumn{7}{|l|}{} \\
\hline Опитина & 45.486 & 7.304 & 57.990 & 41,1 & 6,6 & 52,3 \\
\hline Град & 25.934 & 5.437 & 30.217 & 42,1 & 8,8 & 49,1 \\
\hline Остала насеља & 19.543 & 1.867 & 27.773 & 39,7 & 3,8 & 56,5 \\
\hline \multicolumn{7}{|l|}{} \\
\hline Опитина & 59.140 & 23.883 & 43.850 & 46,5 & 18,8 & 34,5 \\
\hline Град & 36.312 & 16.082 & 24.532 & 47,1 & 20,9 & 31,8 \\
\hline Остала насеља & 22.828 & 7.801 & 19.318 & 45,6 & 15,6 & 38,6 \\
\hline
\end{tabular}

Извор података: CDI-IDN,1970;C3C,1974a; P3C,2003r.

На простору Општине приметна је тенденција повећања броја и удела активног становништва и становништва са личним приходима у укупном становништву, уз истовремено смањивање апсолутног и релативног значаја издржаваног становништва. Повећању економске активности становништва општине Панчево у периоду 1971-2002. година првенствено доприноси већа економска активност становништва града Панчева и приградских насеља Јабуке, Старчева и Качарева. Реч је о све већој економској активности жена у овим насељима, с обзиром да је економска активност мушкараца на нивоу Општине смањена. Смањивање удела издржаваног становништва последица је старења становништва на простору Општине.

Табела 27. Становништво према економској активности 2002. године

\begin{tabular}{|l|c|c|c|c|c|c|c|}
\hline \multicolumn{1}{|c|}{ Територија } & Укупно & Активно & $\%$ & $\begin{array}{c}\text { Лица са } \\
\text { личним } \\
\text { приходима }\end{array}$ & $\%$ & $\begin{array}{c}\text { Издржавана } \\
\text { лица }\end{array}$ & $\%$ \\
\hline Б. Брестовац & 3517 & 1608 & 45,7 & 577 & 16,4 & 1314 & 37,4 \\
\hline Б. Ново Село & 7345 & 3352 & 45,6 & 1055 & 14,4 & 2894 & 39,4 \\
\hline Глогоњ & 3178 & 1429 & 45,0 & 498 & 15,7 & 1248 & 39,3 \\
\hline Долово & 6835 & 3045 & 44,6 & 870 & 12,7 & 2914 & 42,6 \\
\hline Иваново & 1131 & 484 & 42,8 & 213 & 18,8 & 434 & 38,4 \\
\hline Јабука & 6312 & 3008 & 47,7 & 951 & 15,1 & 2336 & 37,0 \\
\hline Качарево & 7624 & 3376 & 44,3 & 1388 & 18,2 & 2846 & 37,3 \\
\hline Омољица & 6518 & 3040 & 46,6 & 1001 & 15,4 & 2470 & 37,9 \\
\hline Панчево & 77.087 & 36.312 & 47,1 & 16.082 & 20,9 & 24.532 & 31,8 \\
\hline Старчево & 7615 & 3486 & 45,8 & 1248 & 16,4 & 2862 & 37,6 \\
\hline Општина Панчево & 127.162 & 59.140 & 46,5 & 23.883 & 18,8 & 43.850 & 34,5 \\
\hline Војводина & 2.031 .992 & 912.800 & 44,9 & 408.999 & 20.1 & 706.843 & 34,8 \\
\hline
\end{tabular}

Извор података:Р3С,2003r.

Године 2002. у структури становништва Општине према економској активности највећи део чинило је активно становништво $(46,5 \%)$, једну трећину издржавана лица, и нешто мање од $20 \%$ су била лица са личним приходима. Највеће стопе активности становништва су у граду Панчеву, где живи више од половине активног становништва Општине, и приградском насељу Јабуци. Долово је насеље карактеристично по највеһем уделу издржаваних лица (чак $42,6 \%$ ) и најмањем уделу лица са личним приходима у укупном становништву. Оваква економска структура становништва резултат је великог удела младих у укупној популацији. 
Стопа активности становништва Панчева, као однос између укупног и активног становништва, већа је у односу на војвођански просек с обзиром на нешто повољнију старосну структуру становништва Општине. Од суседних банатских општина већу стопу активности има само становништво Опова, чему доприноси аграрна функционална оријентација ове општине и изражена активност становништва у пољопривреди.

Аналогно јачању сектора услуга у Општини и повећању броја запослених у терцијарним и квартарним делатностима, популација жена на простору општине Панчево економски је активнија за око 15 процентних поена у односу на шездесете године прошлог века. У активном становништву општине Панчево и њених суседних општина жене су чиниле око $30 \%$ 1961. године. Ангажовање женске радне снаге у сеоским насељима Панчева било је мање у односу на град. У граду су жене учествовале у укупном активном становништву са $32,4 \%$, а у осталим насељима са $27,3 \% 1961$. године (Р3С,1967). Удео жена у укупном активном становништву општине Панчево 2002. године износио је $43 \%$ на нивоу Општине, односно $46 \%$ за град Панчево. Пораст активности женског радно способног становништва у складу је са емпиријски утврђеним законитостима о кретању запослености у постиндустријском друштву (Аџић C., 2006). Тренд повеһане економске активности жена одражава се и на промену улоге и учешћа жена у дневном миграционом процесу.

Табела 28. Општа стопа активности становништва према полу 2002. године

\begin{tabular}{|l|c|c|c|}
\hline \multicolumn{1}{|c|}{ Територија } & Мушкарци & Жене & $\begin{array}{c}\text { Коефицијент } \\
\text { економске зависности } \\
\text { укупног становништва }\end{array}$ \\
\hline Б. Брестовац & 56,8 & 35,0 & 117,6 \\
\hline Б. Ново Село & 57,4 & 34,3 & 117,8 \\
\hline Глогоњ & 58,0 & 31,5 & 122,2 \\
\hline Долово & 58,1 & 31,2 & 124,3 \\
\hline Иеаново & 60,5 & 26,0 & 133,7 \\
\hline Јабука & 56,2 & 38,7 & 109,3 \\
\hline Качарево & 54,5 & 34,4 & 125,4 \\
\hline Омолича & 57,4 & 35,9 & 114,2 \\
\hline Панчево & 53,4 & 41,3 & 111,8 \\
\hline Старчево & 54,9 & 36,4 & 117,9 \\
\hline Градска & 53,6 & 40,4 & 113,4 \\
\hline Остала & 57,4 & 34,3 & 117,6 \\
\hline Општина Панчево & 54,7 & 38,8 & 114,5 \\
\hline Војводина & 53,8 & 36,5 & 122,2 \\
\hline
\end{tabular}

Извор података: Р3C;2003r.

Повећање опште стопе активности становништва Општине у периоду 1971-2002. година, условило је смањивање вредности коефицијента економске зависности у истом периоду. Вредности коефицијента економске зависности, као показатеља односа између активног и неактивног дела становништва 1971. године кретале су се од 195 за Панчево до 114 за Банатско Ново Село (општински просек 144). Године 2002. вредности коефицијента економске зависности становништва кретале су се од 134 у Иванову до 109 у Јабуши (општински просек 115, односно на 100 активних долази 115 економски неактивних лица - углавном лица са личним приходима).

Промене структуре економски активног становниитва према обележју "обављь занимање" - Информације о активном становништву које обавља занимање могу се добити од Пописа становништва из 1981. године. Активно становништво које 
обавља занимање чине лица стара 15 и више година која обављају одређену врсту послова у циљу стицања средстава за живот. Удео запосленог у укупном активном становништву представља један од критеријума за мерење друштвено-економске развијености сваког подручја. Активно становништво које обавља занимање такође је показатељ у којој су мери искоришћени радни потенцијали становништва Општине, односно какве су могућности општине Панчево да апсорбује радни контингент становништва и укључи га у процес рада. Око $60 \%$ активног становништва Панчева 1961. године било је запослено - у радном односу. У околним општинама удео запослених у укупном броју активних био је врло низак, а удео запослених у пољопривреди у односу на укупан број запослених висок (Đošić D.,1970). Године 1981., чак $92,5 \%$ активних лица на простору Општине обављало је неко занимање, док се у 2002. години тај удео смањио на $73,2 \%$. Смањен број запослених и поред повећања броја и удела лица са личним приходом, који значе ослобађање радних места, указује на проблеме запошљавања у панчевачкој привреди изазване њеном трансформацијом тј. преласком на рационалније пословање којом приликом су се јавили и знатни вишкови радне снаге (Универзитет у Новом Саду, ПМФ-Институт за географију, 1996). Највећи степен запослености 2002. године остварен је у Долову и граду Панчеву, а најмањи у Глогоњу. Треба напоменути да се број активних лица која обављају занимање смањио у последњој деценији на нивоу Општине за 4.424 лица. Ово смањење забележила су сва насеља осим Долова, што се одразило и на промене у апсолутном броју дневних миграната.

Табела 29. Активно становништво које обавља занимање (\%) 2002.

\begin{tabular}{|l|c|c|c|c|c|c|}
\hline \multicolumn{1}{|c|}{ Територија } & $\begin{array}{c}\text { Активна } \\
\text { лица која } \\
\text { обављају } \\
\text { занимање }\end{array}$ & Мушкарци & $\%$ & Жене & $\%$ & $\begin{array}{c}\text { Удео активних лица } \\
\text { која обављају } \\
\text { занимање у укупном } \\
\text { активном } \\
\text { становништву }\end{array}$ \\
\hline Б. Брестовац & 1120 & 738 & 65,9 & 382 & 34,1 & 69,7 \\
\hline Б. Ново Село & 2409 & 1539 & 63,9 & 870 & 36,1 & 71,9 \\
\hline Глогоњ & 928 & 663 & 71,4 & 265 & 28,6 & 64,9 \\
\hline Долово & 2396 & 1625 & 67,8 & 771 & 32,2 & 78,7 \\
\hline Иваново & 339 & 240 & 70,8 & 99 & 29,2 & 70,0 \\
\hline Јабука & 1985 & 1265 & 63,7 & 720 & 36,3 & 66,0 \\
\hline Качарсво & 2286 & 1484 & 64,9 & 802 & 35,1 & 67,7 \\
\hline Омолица & 2144 & 1395 & 65,1 & 749 & 34,9 & 70,5 \\
\hline Панчево & 27.296 & 15.047 & 55,1 & 12.249 & 44,9 & 75,2 \\
\hline Старчево & 2388 & 1551 & 64,9 & 837 & 35,1 & 68,5 \\
\hline Општина Панчево & 43.291 & 25.547 & 59,0 & 17.744 & 41,0 & 73,2 \\
\hline
\end{tabular}

Извор података:Р3С,2003r.

Удео активних жена које обављају занимање у укупном активном становништву општине Панчево повећан је у периоду $1991-2002$. година са $38,8 \%$ на $41 \%$. На 100 економски активних мушкараца који обављају занимање долази 69 жена. Најмањи удео жена у активном становништву које обавља занимање имају насеља Глогоњ и Долово, а највећи град Панчево и Јабука. Стопа запослености (број запослених на 1000 становника), као показатељ степена економске развијености општине износи 340 на нивоу Општине, односно за мушкарце 413, а за жене 271.

Промене структуре активног становниитво према делатности - Структура активног становништва према делатности упуһује на карактеристике привреде општине Панчево и степен њеног привредног развоја. Највећи број општина у Војводини 1961. године имао је руралне карактеристике уз низак степен развијености структуре 
делатности: У то време само су четири општине биле мешовитог типа са уравнотеженим односом секундарних и терцијарно-квартарних делатности (Суботица, Нови Сад, Зрењанин и Панчево) и то са јаким утицајем града на карактер општине. Као последица деловања градова као центара развоја дошло је до значајних измена у укупној структури делатности поменутих општина (Вељковић А., Јовановић Р., Тошић Б., 1995). Године 1961. у примарним делатностима општине Панчево било је запослено $40,9 \%$ становништва, у секундарним $33,6 \%$ и у терцијарним $25,5 \%$. У суседним општинама, осим Београда, преко $70 \%$ запослених радило је у примарним делатностима, док су услужне делатности биле доста слабо развијене. У Београду је у примарним делатностима у то време радило $17 \%$ активног становништва (С3С,19656). Рангирање водећих делатности по броју запослених у пет најзначајнијих градова Баната показало је да су у Панчеву водеће делатности 1961. године биле индустрија, трговина и угоститељство. У то време Панчево и Зрењанин били су индустријско-трговински центри насупрот Вршцу и Белој Цркви као аграрно-индустријским насељима (Илић J.,1967). У граду Панчеву је 1961. године $34,3 \%$ активног становништва било запослено у индустрији, као најзначајнијој делатности у граду. Развијена индустрија утицала је да је Панчево имало диверзификовану структуру делатности још 1971. године. У граду Панчеву 1971. године свега $8 \%$ становништва се активно бавило пољопривредом, у приградским насељима између 20 и $40 \%$, а у осталим насељима између $50 \%$ и $80 \%$ становништва (СЗС,19746). Поред изражене просторне покретљивости становништва која се одвијала на простору Општине 60-их и 70-их година прошлог века дошло је и до друштвене покретљивости активног становништва између различитих делатности. Становништво је највише прелазило из пољопривреде у секундарни сектор делатности. Учешће примарног сектора у структури становништва према делатности смањено је за једну трећину у периоду 1971-2002. година. Највећи пораст у истом периоду остварило је учешће запослених у терцијарним делатностима, које се по значају приближавају индустрији као водећој привредној делатности Општине.

Табела 30. Активно становнинтво према делатности 1971. године

\begin{tabular}{|l|c|c|c|c|c|c|c|c|}
\hline \multirow{2}{*}{ Територија } & \multicolumn{4}{|c|}{ Укупно } & \multicolumn{4}{c|}{ Удео у активном становништву } \\
\cline { 2 - 9 } & $\mathrm{N}$ & $\mathrm{C}$ & $\mathrm{T}$ & $\mathrm{Q}$ & $\Pi$ & $\mathrm{C}$ & $\mathrm{T}$ & $\mathrm{Q}$ \\
\hline Б. Брестовац & 1167 & 148 & 1315 & 61 & 73,9 & 9,4 & 9,7 & 3,9 \\
\hline Б. Ново Село & 2555 & 277 & 2832 & 93 & 76,4 & 8,3 & 10,7 & 2,8 \\
\hline Глогоњ & 677 & 217 & 894 & 58 & 61,3 & 19,7 & 9,4 & 5,3 \\
\hline Долово & 2313 & 111 & 2424 & 97 & 84,2 & 4,0 & 6,1 & 3,5 \\
\hline Иваново & 434 & 33 & 467 & 30 & 75,5 & 5,7 & 12,2 & 5,2 \\
\hline Јабука & 735 & 780 & 1515 & 98 & 38,1 & 40,5 & 13,1 & 5,1 \\
\hline Качарево & 584 & 1259 & 1843 & 144 & 22,6 & 48,7 & 18,4 & 5,6 \\
\hline Омољица & 1117 & 513 & 1630 & 94 & 55,7 & 25,6 & 9,9 & 4,7 \\
\hline Панчево & 2174 & 10.967 & 13.141 & 4047 & 8,7 & 44,1 & 25,9 & 16,3 \\
\hline Старчево & 943 & 836 & 1779 & 89 & 40,4 & 35,8 & 15,8 & 3,8 \\
\hline Општина Панчево & 12.699 & 15.141 & 8585 & 4811 & 29,5 & 36,0 & 19,9 & 11,2 \\
\hline Градска & 3701 & 13062 & 7281 & 4280 & 12,4 & 43,9 & 24,5 & 14,4 \\
\hline Остала & 8998 & 2445 & 1304 & 531 & 67,8 & 18,4 & 9,8 & 4,0 \\
\hline Војводина & 369.714 & 173,421 & 149.257 & 76.174 & 46,9 & 22,0 & 19,0 & 9,7 \\
\hline
\end{tabular}

Разлику до $100 \%$ чине лица непознате делатности и ван делатности

Извор података:С $3 \mathrm{C}, 19746$.

Привредни развој Општине одразио се на промене у структури становништва према делатности и на нивоу појединачних насеља. Уопште, дошло је до повећања учешћа неаграрних сектора и битног смањења значаја примарног сектора. Најснажније 
промене у структури становништва према делатности остварене су у насељу Глогоњ, које је иако са мањим потенцијалом за трансфер активног пољопривредног становништва у непољопривредне делатности од других сеоских насеља (мање од $75 \%$ становништва запосленог у примарним делатностима 1971. године) имало најинтензивнији процес деаграризације становништва. Учешће активног становништва запосленог у примарним делатностима у Глогоњу смањено је за чак $46 \%$ у периоду 1971-2002. година. На рачун смањења радника примарног сектора повећаo се удео запослених у секундарним делатностима. Карактер насеља са највећим уделом запослених у примарном сектору делатности задржало је Долово. У индустрији, као најзначајнијој делатности Панчева, 2002. године било је запослено више од половине активног становништва Глогоња, Јабуке и Старчева.

Табела 31. Активно становништво према делатности 2002. године

\begin{tabular}{|l|c|c|c|c|c|c|c|c|}
\hline \multirow{2}{*}{ Територија } & \multicolumn{4}{|c|}{ Укупно } & \multicolumn{3}{c|}{ Удео у активном становништву } \\
\cline { 2 - 9 } & $\mathrm{\Pi}$ & $\mathrm{C}$ & $\mathrm{T}$ & $\mathrm{Q}$ & $\mathrm{\Pi}$ & $\mathrm{C}$ & $\mathrm{T}$ & $\mathrm{Q}$ \\
\hline Б. Брестовац & 362 & 330 & 260 & 121 & 32,3 & 29,5 & 23,2 & 10,8 \\
\hline Б. Ново Село & 946 & 711 & 481 & 233 & 39,3 & 29,5 & 20,0 & 9,7 \\
\hline Глогоњ & 141 & 484 & 187 & 94 & 15,2 & 52,2 & 20,2 & 10,1 \\
\hline Долово & 1103 & 598 & 394 & 241 & 46,0 & 25,0 & 16,4 & 10,1 \\
\hline Иваново & 111 & 131 & 58 & 29 & 32,7 & 38,6 & 17,1 & 8,6 \\
\hline Јабука & 192 & 1000 & 485 & 269 & 9,7 & 50,4 & 24,4 & 13,6 \\
\hline Качарево & 212 & 993 & 600 & 392 & 9,3 & 43,4 & 26,2 & 17,1 \\
\hline Омолича & 462 & 901 & 457 & 243 & 21,5 & 42,0 & 21,3 & 11,3 \\
\hline Панчево & 1065 & 10.710 & 9831 & 5084 & 3,9 & 39,2 & 36,0 & 18,6 \\
\hline Старчево & 250 & 1207 & 597 & 286 & 10,0 & 50,5 & 25,0 & 12,0 \\
\hline Општина Панчево & 4844 & 17.065 & 13.350 & 6992 & 11,2 & 39,4 & 30,8 & 16,2 \\
\hline Градска & 1527 & 12.910 & 11.028 & 5762 & 4,8 & 40,4 & 34,5 & 18,0 \\
\hline Остала & 3317 & 4155 & 2322 & 1230 & 29,3 & 36,7 & 20,5 & 10,9 \\
\hline војводина & 159.723 & 228.766 & 190.041 & 104.764 & 22,8 & 32,6 & 27,1 & 14,9 \\
\hline
\end{tabular}

Разлику до $100 \%$ чини непознато и остале делатности

Извор података:Р3С,2004r.

Удео активног становништва примарног сектора често се посматра као индикатор степена развијености неког подручја. Типологија насеља Панчева према учешћу активног становништва у примарном сектору делатности изведена је на основу метода А. Вељьковића (Вељковић А.и др., 1995). На основу ове методе, према подацима из 1971. године, издвојени су следећи типови насеља у општини Панчево:

- град Панчево као изразито неаграрно насеље са до 10\% активног становништва запосленог у примарним делатностима,

- Качарево као неграрно насеље са $10 \%-25 \%$ активног становништва запосленог у примарним делатностима,

- Јабука и Старчево као мешовита насеља са $25 \%-50 \%$ активног становништва запосленог у примарним делатностима,

- Омољица, Банатски Брестовац и Глогоњ као аграрна насеља подтип 1 са учешћем пољопривредног становништва у активном између $50 \%$ и $75 \%$ и

- Банатско Ново Село, Долово и Иваново као аграрна насеља подтип 2 са учешћем пољопривредног становништва у активном између $75 \%$ и $90 \%$.

Као резултат снажних миграција правца село-град, подстакнутих процесом урбанизације од шездесетих година прошлог века, дошло је до функционалне трансформације насеља Општине. Динамичне промене у структури становништва 
према делатности на простору Општине условиле су прелазак аграрних насеља у друге типове насеља у периоду 1971-2002. година. Процес деаграризације био је нарочито буран у приградским насељима. Године 2002. Јабука и Качарево заједно са градом Панчевом, са до $10 \%$ активног становништва запосленог у примарним делатностима изразито су неаграрна насеља, док се Старчево са $10 \%$ запосленог становништва у примарним делатностима налази се на граници између изразито неаграрног и неаграрног насеља. Старчево је приградско насеље у коме се процес деаграризације најспорије одвијао, те је знатно смањење активног становништва примарног сектора забележено и у последњем међупописном периоду. У другим приградским насељима удео запослених у примарним делатностима у последњем десетогодишту релативно стагнира, након остварених промена у претходним периодима. Неаграрна насеља према типологији А. Вељковића су Глогоњ и Омољица, а Банатски Брестовац, Банатско Ново Село, Долово и Иваново су мешовита насеља. Приградска насеља Општине потврђују сазнања да се у приградским насељима Баната пољопривредом бави мање од петине становништва, те да ова насеља имају знатан удео индустријских радника у структури становништва према делатности. Мањи удео неаграрног становништва у укупном активном становништву указује на снагу градских функција околних градова (Ћурчић С., 2004). Функционалне промене у приградским насељима пратиле су и интензивне популационе промене. Насеља у приградској зони са најмањим уделом запослених у примарним делатностима у укупном активном становништву бележе уједно и највећи пораст броја становника у периоду 1948/2002. година.

У периоду 1991-2003. година, на простору Панчева, смањен је удео запослених у индустрији и грађевинарству а повећан удео запослених у здравству и образовању. Удео запослених у трговини је релативно непромењен (Р3С, 1992а, 2003). Сагласно напред разматраним променама у економској структури становништва могу се очекивати и одговарајуће промене у обиму и структури дневних миграционих токова активног становништва. Даље формирање токова дневних миграција на простору општине Панчево биће под утицајем промена у секторској структури запослених и повећања економске активности жена.

Промене обима и удела пољопривредног становниитва у укупиом - Природа обављања примарних делатности већином подразумева близину а најчешће и једнакост насеља становања и насеља рада, што само по себи искључује могућност учешћа радника запослених у примарним делатностима у дневним миграционим токовима активног становништва (Лукић В., 2007). Стога је за пољопривредно становништво специфично ниско учешће $\mathrm{y}$ дневним миграцијама. Међутим, проучавање пољопривредног становништва значајно је са аспекта проучавања категорије становништва са двојном делатношћу и домаһинстава са двојним изворима прихода појаве изражене нарочито после Другог светског рата.

Учешће пољопривредног у укупном становништву општине Панчево смањено је са $38,3 \%$ 1961. године на свега $5 \%$ 2002. године. Мање од половине пољопривредног у укупном становништву 1961. године имала су само насеља Јабука, Качарево и Панчево. Удео пољопривредног становништва у граду Панчеву са Војловицом износио је $11,2 \%$. Илић истиче да је на смањење броја и удела пољопривредног становништва Панчева имало утицаја запошљавање знатног броја Панчеваца у Београду и у то време. Вршац и Бела Црква имали су 1961. године преко једне петине пољопривредног становништва. У овим градовима је и пре Другог светског рата било више пољопривредног становништва него у Панчеву. На то је утицала знатно слабије развијена индустрија и друге непољопривредне делатности, у односу на Панчево и Зрењанин, као и њихов лошији саобраһајно-географски положај у односу на функционално - активне центре (Илић J.,1967). 
Табела 32. Пољопривредно становништво 1971. године

\begin{tabular}{|l|c|c|c|}
\hline \multirow{2}{*}{ Територија } & \multicolumn{3}{|c|}{ Становнитво } \\
\cline { 2 - 4 } & Укупно & Пољопривредно & $\begin{array}{c}\text { Удео пол.становништва } \\
\text { у укупном }\end{array}$ \\
\hline Банатски Брестовац & 3809 & 2574 & 67,6 \\
\hline Банатско Ново Село & 7872 & 5158 & 65,5 \\
\hline Глогоњ & 3257 & 1799 & 55,2 \\
\hline Долово & 6582 & 5393 & 81,9 \\
\hline Иваново & 1893 & 1258 & 66,5 \\
\hline Јабука & 5453 & 1619 & 29,7 \\
\hline Качарево & 8088 & 1552 & 19,2 \\
\hline Омолица & 5693 & 2770 & 48,7 \\
\hline Панчево & 61.588 & 4325 & 7,0 \\
\hline Старчево & 6545 & 2287 & 34,9 \\
\hline Општина Панчево & 110.780 & 28.735 & 25,9 \\
\hline
\end{tabular}

Смањење броја и удела пољопривредног становништва резултат је општег економског развоја Општине. Услед потреба индустрије за радном снагом градски центар апсорбовао је радну снагу из других насеља. Процес деаграризације био је условљен ниским нивоом развијености пољопривреде, али и великим економским и социјалним разликама које су постојале између града и села. Смањење бројности пољопривредног становништва веће од сеоског резултат је укључености активног становништва у дневне миграционе токове. Поред трансфера становништва у друге делатности и миграција правца село - град, на смањење броја пољопривредног становништва деловала је и природна компонента. "Пољопривредно становништво у Војводини је деценијама имало природни прираштај нижи него у осталим деловима Србије" (Петровић Р.,1979).

Табела 33. Укупно пољопривредно и активно пољопривредно становништво 2002. године

\begin{tabular}{|c|c|c|c|c|c|c|c|}
\hline \multirow{3}{*}{ Територија } & \multicolumn{7}{|c|}{ Становништво } \\
\hline & \multirow[b]{2}{*}{ Укупно } & \multirow[b]{2}{*}{ Активно } & \multicolumn{2}{|c|}{ Польоривредно } & \multicolumn{3}{|c|}{ Активно пољьоривредно } \\
\hline & & & $6 p o j$ & $\begin{array}{c}\text { у укупном } \\
(\%)\end{array}$ & $6 \mathrm{poj}$ & $\begin{array}{c}\text { у активном } \\
(\%)\end{array}$ & $\begin{array}{c}y \\
\text { nольопривредном } \\
\text { (\%) }\end{array}$ \\
\hline 5. Брестовац & 3517 & 1608 & 470 & 13,4 & 288 & 17,9 & 61,3 \\
\hline 5. Ново Село & 7345 & 3352 & 1474 & 20,1 & 892 & 26,6 & 60,5 \\
\hline Tnorots & 3178 & 1429 & 225 & 7,1 & 128 & 9,0 & 56,9 \\
\hline Долово & 6835 & 3045 & 1696 & 24,8 & 960 & 31,5 & 56,6 \\
\hline Иваново & 1131 & 484 & 126 & 11,1 & 87 & 18,0 & 69,0 \\
\hline Јабука & 6312 & 3008 & 190 & 3,0 & 136 & 4,5 & 71,6 \\
\hline Качарево & 7624 & 3376 & 266 & 3,5 & 122 & 3,6 & 45,9 \\
\hline Омољича & 6518 & 3040 & 562 & 8,6 & 327 & 10,8 & 58,2 \\
\hline Панчево & 77.087 & 36.312 & 948 & 1,2 & 432 & 1,2 & 45,6 \\
\hline Старчево & 7615 & 3486 & 367 & 4,8 & 149 & 4,3 & 40,6 \\
\hline Градска & 92.326 & 43.174 & 1581 & 1.7 & 703 & 1,6 & 44,5 \\
\hline Octana & 34.836 & 15.966 & 4743 & 13,6 & 2818 & 17,7 & 59,4 \\
\hline Општина Панчево & 127.162 & 59.140 & 6324 & 5,0 & 3521 & 6,0 & 55,7 \\
\hline Војводина & 2.031 .992 & 912.800 & 215.147 & 10,6 & 125.506 & 13,7 & 58,3 \\
\hline
\end{tabular}

Извор података: Р3С, 2004 д. 
У односу на шире регионалне и макрорегионалне целине у Панчеву се становништво знатно мање активно бави пољопривредом. Активно пољопривредно становништво чини $58 \%$ од укупног пољопривредног становништва и $13,7 \%$ од укупног активног становништва у Војводини, док за Панчево ове вредности износе $56 \%$ односно свега $6 \%$, 2002. године. Највећи удео пољопривредног становништва у укупном имају насеља Долово и Банатско Ново Село, док у градским насељима пољопривредно становништво чини свега $2 \%$ од укупног становништва. Паралелно са смањивањем броја и удела пољопривредног становништва у укупном повећавала се активност пољопривредног становништва Панчева до вредности од 56\% (Р3С, 2004д).

Промене структуре становниитва према образоваьу - Структура становништва Панчева према писмености и нивоу квалификованости значајна је како сама по себи, као илустрација образовних потенцијала Општине и степена њене развијености, тако и због свог утицаја на промене других структура становништва и природне и механичке компоненте популационе динамике, а тиме и промене обима структуре и праваца дневних миграционих кретања. У теоретским разматрањима миграција утемељено је мишљење о корелацији између степена мобилности становништва и достигнутог нивоа образовања.

Паралелно са друштвено-економским развојем Панчева и градских функција одвијале су се и позитивне промене у структури становништва у смислу унапређења образованости становништва, како у погледу писмености тако и погледу школске спреме. У општини Панчево 1961. године сваки десети становник био је неписмен, у Панчеву сваки двадесети, а у насељима Банатски Брестовац, Глогоњ и Јабука сваки пети становник (Универзитет у Новом Саду, ПМФ-Институт за географију, 1996). Углавном је неписмено било старије становништво, премда је било и млађег неписменог становништва. Код свих старосних група проценат женског неписменог становништва био је знатно већи од мушког. Промене у структури становништва према образовању које су уследиле указују на смањивање удела неписмених са $11,3 \% 1961$. године на 2,6\% 2002. године, када је реч о становништву Општине старијем од десет година. У последњем међупописном периоду удео неписмених становника готово је преполовљен са $4,8 \%$ на $2,6 \%$. Неписменост је и даље знатно израженија код женске популације $(4,4 \%)$, док је код мушкараца готово ишчезла $(1,1 \%)$. Највећи проценат неписмених становника имају насеља која нису градска по типу $(5,2 \%$ од укупног становништва старијег од десет година). Удео неписмених у женској популацији ових насеља достиже чак $8,2 \%$, чему доприноси велики број неписмених жена преко 65 година старости, као резултат неједнаког обухвата деце оба пола школовањем код ових генерација (СЗС,1974в.;Р3С,2003д). На нивоу Општине неписменост је такође најизраженија код старијег становништва, чије се школовање одвијало у другачијим друштвено-економским условима, те се проценат неписмених знатно повећава код лица старих од педесет година навише.

Ниво образовања становништва посредно утиче на привредну активност, ставове o величини породице, способност становништва да прихвата иновације, итд. Ово обележје становништва представља квалитативну особеност радне снаге. У односу на војвођански просек становништво Панчева према свим пописима од шездесетих година двадесетог века има повољнију образовну структуру становништва. Општина Панчево налази се у групи општина Војводине и Србије са највишим нивоом квалификованости становништва (Бурсаћ М.,2003).

Ако се посматра удео становништва са одређеном школском спремом у односу на укупно становништво, општина Панчево са 10.851 или $8,5 \%$ налази се међу пет општина Војводине са највећим уделом лица са високим и вишим образовањем, одмах након Новог Сада, Сремских Карловаца, Зрењанина и Вршца, а на трећем месту у 
Војводини по уделу лица са високим образовањем (5.856 или 4,6\%) у укупном становништву. Овакав однос првенствено је резултат повољне образовне структуре становништва града Панчева. Већи удео лица са завршеном основном школом и завршеном школом за квалификоване раднике доприносио је да се становништво општине Панчево још 1961. године одликовало развијенијом образовном структуром у односу на суседне општине, иако је релативно низак проценат омладине у то време настављао образовање после завршене основне школе. Од укупног становништва старог 15-19 година њих $37,5 \%$ у Панчеву а $25,9 \%$ у осталим насељима општине Панчево настављало је школовање (CDI-IDN, 1970). У структури становништва према школској спреми, становништво са завршеном школом вишом од основне шездесетих година прошлог века чинило је $24,8 \%$, док је 2002 . године $85 \%$ од укупног становништва старијег од 15 година имало најмање завршену основну школу. Овај однос је за Војводину био $13,7 \%$ за 1961 . годину на према $75,1 \% 2002$. године (Р3С, 1967;Р3С,2003д).

Табела 34. Становништво општине Панчево према школској спреми ${ }^{13}(\%)$

\begin{tabular}{|c|c|c|c|c|c|c|c|}
\hline & Укупно & $\begin{array}{c}\text { Без школске } \\
\text { спреме }\end{array}$ & $\begin{array}{c}\text { Незавршена } \\
\text { основна школа }\end{array}$ & Ош & СШ & Виша & Висока \\
\hline \multicolumn{7}{|c|}{} \\
\hline Укупно & 94.820 & 17,6 & 41,2 & 15,3 & 22,3 & 1,4 & 1,9 \\
\hline$M$ & 46.495 & 11,7 & 37,9 & 14,3 & 31,2 & 1,7 & 2,7 \\
\hline$\not{X}$ & 48.325 & 23,2 & 44,3 & 16,2 & 13,7 & 1,1 & 1,1 \\
\hline \multicolumn{7}{|c|}{} \\
\hline Укупно & 107.580 & 6,2 & 10,1 & 23,6 & 48,8 & 4,6 & 5,4 \\
\hline$M$ & 51.683 & 3,5 & 7,3 & 21,3 & 56,0 & 4,5 & 6,1 \\
\hline$\not{K}$ & 55.897 & 8,7 & 12,8 & 25,8 & 42,2 & 4,8 & 4,9 \\
\hline
\end{tabular}

Извор података: CDI-IDN, 1970;Р3C,2003д.

У структури становништва Општине према школској спреми преовладава становништво са завршеном средњом школом. Важно је напоменути податке о становништву са вишим и високим образовањем, с обзиром да развој науке и технике и средстава за производњу условљава пораст потреба за квалификованијом радном снагом. У Панчеву је 2002. године живела половина становништва Јужно-банатског округа са вишим и високим образовањем. Десет одсто становништва Панчева старијег од петнаест година има завршену вишу или високу школу. Удео становништва са овим нивоом квалификација у Банату је $8,6 \%$ а на нивоу Војводине $8 \%$. Надпросечан удео лица са завршеним вишим и високим образовањем у односу на просек како Баната тако и Војводине последица је привредне структуре панчевачке општине, али и административно-управне функције града Панчева. У функцији привреде Панчева је и више од половине средњошколаца са завршеном средњом стручном школом.

Насеља која нису градска по типу имају знатно неповољнији ниво квалификованости становништва у односу на градска насеља. Као пример диспропорције у образовној структури становништва Панчева према типу насеља јесте дистрибуција становништва са завршеном вишом и високом школом, којих има три пута више у градским насељима. Концентрација високошколских кадрова у општинском центру резултат је потреба града Панчева као индустријског и административног центра Јужног Баната и развијености градских функција. Разликама у стручној спреми становништва градских и осталих насеља доприносе и разлике су

13 За 1971. годину становништво старије од 10 година а за 2002. годину становништво старије од 15 година. 
старосној структури становништва. У поређењу са становништвом других сеоских насеља на нивоу Јужно-банатског округа и Војводине насеља панчевачке општине која нису градска по типу имају слабије кадровске потенцијале. Диференцијација становништва према школској спреми на нивоу насеља указује да су поред општинског центра, повољнију структуру становништва према школској спреми 1991. године имала насеља Качарево, Јабука, Омољица и Старчево, у којима је око $40 \%$ становништва било са средњом, вишом или високом школском спремом (Милетић Р.,1999).

Промене образовне структуре економски активног становништва Достигнути ниво квалификованости становништва делује на економску активност, као и на избор одговарајућег занимања. Неусклађеност бројности образованог становништва и нивоа његове квалификованости са потребама локалне привреде директно се одражава на обим и токове дневних миграција, па је образовање значајан фактор формирања токова дневних миграција становништва и њихових правца и усмерености. Ове диспропроције делом представљају резултат неусклађености програма средњег и високог образовања са потребама тржишта рада. Проучавање активних дневних миграната према делатности и степену образовања може да послужи за одређивање и усклађивање смерница развоја привреде и образовног система на простору општине Панчево и шире.

Табела 35. Укупно и активно становништво Панчева према школској спреми 2002, године (\% од становништва старијег од 15 година)

\begin{tabular}{|l|c|c|c|c|c|c|}
\hline \multirow{2}{*}{ Школска спрема } & \multicolumn{2}{|c|}{ Општина } & \multicolumn{2}{c|}{ Градска насеља } & \multicolumn{2}{c|}{ Остапа насела } \\
\cline { 2 - 7 } & Укупно & Активно & Укупно & Активно & Укупно & Активно \\
\hline Без школске спреме и 1-3 разреда ОШ & 6,2 & 0,8 & 4,4 & 0,6 & 11,0 & 1,3 \\
\hline Непотпуна ОШ & 10,1 & 3,7 & 7,8 & 1,6 & 16,5 & 9,4 \\
\hline Завршена ОШ & 23,6 & 18,2 & 21,8 & 15,0 & 28,5 & 26,7 \\
\hline Средне образоваңе & 48,8 & 63,8 & 52,3 & 66,3 & 39,5 & 56,9 \\
\hline Више и високо образовање & 10,1 & 13,6 & 12,4 & 16,5 & 3,9 & 5,7 \\
\hline
\end{tabular}

Извор података: Р3С,2003д; Р3С, 20066.

Разлике у степену стручне спреме између становништва градских и становништва осталих насеља Панчева нешто су мање изражене када је реч о активном него о укупном становништву, што је потврда утицаја старосне структуре на диференцијације структуре становништва према образовању. Најнеповољнију структуру активног становништва које обавља занимање, према школским квалификацијама, која се огледа у односу радника без квалификација и са незавршеном основном школом према осталом делу радне снаге, имају насеља Банатско Ново Село, Долово и Иваново. За ова насеља је иначе карактеристично да се одликују већим уделом пољопривредног становништва и становништва запосленог у примарним делатностима у поређењу са осталим насељима Општине. У граду Панчеву чак $18 \%$ активног становништва има ниво квалификованости виши од средње стручне спреме, односно $21,5 \%$ када је реч о активном становништву које обавља занимање, тј. оквиру из кога се формирају дневне миграције радника. Поређење података о активном становништву према школској спреми и активном становништву које обавља занимање према школској спреми на нивоу насеља имплицира да се у Панчеву лакше запошљава становништво са вишим и високим образовањем, с обзиром да је удео лица са овим квалификацијама у групи активног становништва које обавља занимање већи од његовог удела у укупном активном становништву (Р3С, 2006б).

Промене у етничком саставу становниитва - Карактеристике области најсложеније националне композиције становништва, које је задобила већ у 18. веку, Војводина је у европским размерама очувала и до данас (Радовановић М., 1996). На стварање мултиетничке структуре становништва Панчева утицали су бројни историјски 
фактори. Актуелна етничка структура становништва резултат је у највећој мери бројних миграционих процеса различитог карактера који су се одиграли на овом простору и шире. Поред миграција и природног прираштаја становништва, на измене етничке структуре Панчева утицала је у мањој мери и промена националног опредељења.

Табела 36. Становништво општине Панчево према националној припалности

\begin{tabular}{|c|c|c|c|c|c|c|}
\hline \multirow{2}{*}{$\begin{array}{l}\text { Национална } \\
\text { припадност }\end{array}$} & \multicolumn{2}{|c|}{1971} & \multicolumn{2}{|c|}{1991} & \multicolumn{2}{|c|}{2002} \\
\hline & Epof & $\%$ & Бpoj & $\%$ & 5poj & $\%$ \\
\hline Срби & 74.321 & 67,1 & 86.333 & 68,9 & 97.137 & 76,4 \\
\hline Црногорци & 1307 & 1,2 & 1729 & 1,4 & 1003 & 0,8 \\
\hline Jугословени & 2767 & 2,5 & 10101 & 8,1 & 2992 & 2,4 \\
\hline Албанци & 186 & 0,2 & 85 & 0,1 & 48 & 0,0 \\
\hline Бугари & 1129 & 1,0 & 727 & 0,6 & 563 & 0,4 \\
\hline MaҺapn & 7288 & 6,6 & 5043 & 4,0 & 4037 & 3,2 \\
\hline Македонци & 8888 & 8,0 & 8488 & 6,8 & 5276 & 4,1 \\
\hline Муслимани & 591 & 0,5 & 757 & 0,6 & 543 & 0,4 \\
\hline Немци & 692 & 0,6 & 309 & 0,2 & 227 & 0,2 \\
\hline Роми & 294 & 0,3 & 1001 & 0,8 & 1392 & 1,1 \\
\hline Румунии & 6672 & 6,0 & 5052 & 4,0 & 4065 & 3,2 \\
\hline Pycn & 176 & 0,2 & 90 & 0,1 & 69 & 0,1 \\
\hline Cnовачи & 2141 & 1,9 & 1744 & 1,4 & 1578 & 1,2 \\
\hline Словенци & 345 & 0,3 & 183 & 0,1 & 140 & 0,1 \\
\hline Хреати & 2743 & 2,5 & 1692 & 1,4 & 1168 & 0,9 \\
\hline Yecn & 78 & 0,1 & 66 & 0,1 & 57 & 0,0 \\
\hline Остали & 227 & 0,2 & 261 & 0,2 & 595 & 0,5 \\
\hline Неизјашњени & 44 & 0,0 & 276 & 0,2 & 2935 & 2,3 \\
\hline $\begin{array}{l}\text { Регионална } \\
\text { припадност }\end{array}$ & 450 & 0,4 & 190 & 0,2 & 398 & 0,3 \\
\hline Hепознато & 441 & 0,4 & 1134 & 0,9 & 2939 & 2,3 \\
\hline
\end{tabular}

Извор података:С ЗС, 1974г;Р3С, 1993;Р3С,2003в.

У односу на хетерогену етничку структуру Војводине бимодалног типа, у којој преовлађују две националности - Срби (65\%) и Мађари (14,3\%), етничка структура становништва Панчева има одлике ниже хетерогености са учешћем Срба од 76,4\% и ниским уделом партиципације осталих етничких група ${ }^{14}$. На подручју општине Панчево живи преко 30.000 припадника различитих националних мањина. Општа карактеристика етничке структуре становништва Панчева је стално повећање броја и удела српског становништва уз смањивање удела осталих етничких група у укупном становништву. Специфичан пример чини промена удела Немаца у етничкој структури. Године 1910. у Панчеву било $36,7 \%$ Немаца (Универзитет у Новом Саду, ПМФИнститут за географију, 1996). Велики број Немаца, колонизиран на ово подручје у 18. веку условио је формирање Горње Вароши насељене Србима и Доње Вароши насељене претежно Немцима. Након исељавања Немаца, после Другог светског рата, нестала је и подела Панчева на ова два дела. Подела је била синоним постојања два Панчева у националном погледу (Илић J.,1967). Данас Немци чине мање од 1\% од укупног становништва Општине. Најбројнију етничку групу, после Срба, чине Македонци $(5.276$, или $4,1 \%)$ што је последица колонизације извршене након Другог светског рата. Према Попису становништва из 1961. године у структури становништва Општине Срби су били заступљени са $64,4 \%$, Македонци са $8,9 \%$, Мађ)ари са $8,2 \%$ и Румуни са $7,7 \%$

\footnotetext{
${ }^{14}$ На основу поделе подручја према етничкој структури становништва аутора Н.Радушки, 2005.
} 
(Р3С, 1967). Македонци су колонизацијом постали бројан народ у панчевачкој општини. Њихов број се повећавао све до 1981. године, захваљујући како природном прираштају тако и досељавањима. Депопулацији Македонаца допринело је смањење досељавања услед слабљења рођачких веза, уз смањени природни прираштај и ефекте које је произвело осамостаљење Македоније као државе (Универзитет у Новом Саду, ПМФ,Институт за географију, 1996). Роми су једина етничка група чији се апсолутан број и учешће у укупном становништву Општине константно повећава. Поред разлика у репродуктивном понашању између Рома и других етничких заједница са ниским наталитетом и нација са већим уделом старих лица у укупном становништву повећању учешћа ромске националности у структури становништва Панчева доприноси и субјективан фактор. Од 70-их година прошлог века долази до "буђења" националне свести и све чешћег националног изјашњавања Рома као таквих, док су се раније углавном изјашњавали као већински народ на подручју на коме живе. Тако велики демографски динамизам и потенцијал ова популација дугује, поред високог природног прираштаја, и позитивној етничкој алтернацији (Радушки, 2005).

Према специфичним одликама етничке структуре могу се издвојити насеља Иваново, Банатско Ново Село, Јабука и Качарево. Ова насеља је 2002, године одликовало веће учешће одређених етничких група у структури укупног становништва у односу на просек за Општину. Етнички је најкомплекснија структура становништва Иванова, која је тримодална. Уједно, ово је насеље на подручју Општине са најмањим уделом Срба у етничкој структури становништва. Од укупног становништва Иванова $20 \%$ чине Срби, 27\% Бугари и 40\% Мађари. Још 1900. године Мађари и Бугари, досељавани стихијно и плански, чинили су већину у овом насељу (Универзитет у Новом Саду, ПМФ,-Институт за географију, 1996). У Банатском Новом Селу живи преко 2.000 Румуна, што чини $27,7 \%$ од укупног становништва овог насеља. Најбројнија етничка група у насељима Јабука и Качарево после Срба су Македонци који чине $19 \%$ од укупног становништва. Све до пописа 1991. године Македонци су били већинско становништво у Јабуци (Р3С,2003в).

Етничка структура становништва одражава се на демографски развој појединачних насеља и општине Панчево у целини, делујуһи на компоненте популационе динамике и на структуру становништва према различитим обележјима. Према социо-професионалној структури активног становништва према етничким групама, 1971. године, Румуни и Бугари су били изразито пољопривредно становништво, док су Македонци имали висок проценат лица са радничким занимањима (Петровић Р., 1979). Године 2002. Румуни су чинили $13 \%$ становништва Долова и $28 \%$ становништва Банатског Новог Села, док су Бугари највише живели у Иванову. Ово су насеља Панчева са највеһим уделом запослених у примарним делатностима 2002. године, што можемо довести у везу и са претходним сазнањима о социо-професионалној структури становништва према етничким групама. Петровић истиче и условно-последичну повезаност социо-професионалне структуре са степеном територијалне покретљивости становништва. Изражавајући територијалну покретљивост процентом лица која су пресељавана преко граница општине у којој живе, примећено је да су код група са претежно пољопривредном структуром проценти пресељаваног становништва били ниски (код Бугара на пример проценат пресељавања био је $20 \%$ ). Проценат лица која су се пресељавала слагао се са заступљеношћу радничких и службеничких занимања, па је међу Македонцима износио 74\% (Петровић P., 1979). 
На савремене процесе везане за промене броја и карактеристика домаћинстава највише утиче пад наталитета и последично изражен процес старења становништва. У последњем међупописном периоду Панчево је поред Опова једна од две банатске општине која бележи пораст броја домаћинстава. У складу са општим трендом повеһања броја домаћинстава на нивоу Војводине, број домаћинстава у општини Панчево повећао се за 25.214 или више од два пута у периоду 1948-2002. година, бележећи константан пораст. У истом периоду број становника Општине расте нешто споријим темпом у односу на број домаһинства, који је у највећој мери резултат промена у структури домаћинстава према броју чланова односно смањивања просечне величине домаћинстава. Пораст броја домаћинстава забележен је стога и у насељима Банатски Брестовац и Глогоњ у којима се смањио број становника. Константан пораст броја домаһинстава најизраженији је у градским насељима - као једна од последица процеса урбанизације. Смањење броја домаһинстава у периоду 1948-2002. год. има само популационо најмање и саобраћајно релативно изоловано насеље Иваново, које од средине 20. века бележи смањење броја становника, већином као резултат биолошке депопулације (Р3С;2004h).

Просечна величина домаћинстава на нивоу Општине износила је 2002. године 2,9 чланова, што одговара вредностима за Војводину. Још од првог пописа после Другог светског рата општина Панчево, са знатно већим уделима градског и непољопривредног становништва, има у просеку мања домаћинства него околне претежно пољопривредне општине (CDI-IDN, 1970). Године 2002. само суседна општина Ковачица имала је у просеку мањи број чланова домаћинства у односу на Панчево (2,7 чланова). На нивоу Општине величина просечног домаћинства смањена је у периоду 1948-2002. година за 0,7. Процес смањивања просечне величине домаћинства изражен је у свим насељима Панчева и најмањи просечан број чланова имају домаћинства у насељима Иваново и Панчево. Домаћинства у општини Панчево 1948. године имала су у просеку око 4 члана. Више од пет чланова домаћинства у то време имала су насеља Глогоњ, Јабука и Качарево у која је досељен велики број колониста после Другог светског рата. Смањење просечног броја чланова домаћинства у периоду 1948-2002. година је и најизраженије у овим насељима. У последњих шездесет година просечна величина домаћинстава у поменутим насељима смањила се у просеку за чак два члана (Р3С;2004ђ). Сматра се да су домаһинства колониста у просеку имала по пет чланова. Колонисте су одликовала већа домаћинства са тенденцијом каснијег дељења. Деоба домаћинстава колониста повратника омогућавала је становништву да задржи и стари и нови посед (Ђурђев Б., 1986). Илић наводи податак о досељавању радника самаца у Качарево и Јабуку шездесетих година прошлог века, што је утицало на повећање броја домаћинства са мањим бројем чланова у то време (Илић Ј., 1967).

У општини Панчево је 2002. године забележен највећи удео домаћинстава са два члана $(24,3 \%)$, потом са четири члана $(23,3 \%)$, и три члана $(20,3 \%)$. Промене у структури домаћинстава према броју чланова током времена одвијале су се паралелно са напред разматраним променама у броју домаћинства и просечној величини домаћинстава. У оквиру саме Општине знатно је измењена структура домаћинстава према броју чланова у зависности од насеља. Генерално се повећава број малих домаћинстава (до четири члана), на рачун смањења броја и удела домаћинстава са више чланова у укупном броју домаһинстава. Учешһе домаһинстава која имају до четири члана у укупном броју домаћинстава Општине повећано је са $55,8 \%$, колико је износило 
1961. године, на $64,3 \%$ 2002. године, док је у исто време учешће великих домаћинстава са седам и више чланова смањено са $4,5 \%$ на $1,5 \%$. Група домаћинстава са четири до шест чланова такође је смањила учешће у укупном броју домаћинстава са $39,6 \% 1961$. године на $34,2 \%$ 2002. године (С 3 , 1965 г; Р3С;2004Ђ). Значајне промене наступиле су и у броју самачких домаћинстава током времена. Број домаћинстава са једним чланом на нивоу Општине повећан је скоро двоструко од седамдесетих година прошлог века, са 4.611 1971. године на 8.548, 2002. године (С ЗС,1974д). Број самачких домаһинстава највише је повећан у сеоским насељима Иванову и Банатском Брестовцу која су захваћена снажним процесима депопулације и старења становништва. Домаћинстава са једним чланом чинила су чак $22 \%$ од укупног броју домаһинстава 2002. године у Иванову. Све већи број домаћинстава са једним чланом у сеоским насељима, која су у највећем броју старачка домаћ̆инства значајна су препрека даљем демографском и целокупном развоју Панчева.

У складу са запаженим трендом смањивања броја вишепородичних домаћинстава и свођења домаћинства на нуклеарну породицу, највећи број домаћинстава у општини Панчево су једнопородична домаћинства $(86,6 \%)$. У структури домаћинстава према типу породице преовладавају породице са децом, док породице без деце чине готово трећину у укупном броју породица сеоских насеља, услед интензивног процеса старења становништва. Карактеристично је насеље Јабука у коме је број породица већи од броја домаћинстава, као последица постојања вишепородичних домаћинстава.

"Процес претапања домаћинстава у породицу у ужем смислу није условљен само демографским факторима већ је у великој мери и последица економског и социолошког осамостаљивања породице” (Брезник Д.,1957, према Bobić M.,1999). Промене структуре домаћинстава према изворима прихода су у узрочно-последичној вези са величином и породичним саставом домаћинства, али и са обимом дневних миграција економски активног становништва. Структура домаћинстава према изворима прихода у зависности је од економске структуре становништва и карактера привреде Општине. Двојни извори прихода за домаћинство карактеристични су били за шездесете године двадесетог века. Од тада се промене у структури домаһинстава према изворима прихода одвијају у правцу смањивања учешћа домаћинстава која имају изворе прихода из пољопривреде. Сеоско домаћинство претрпело је круцијалне промене у три главна сегмента: 1) величини; 2) сродничком саставу и 3) положају и улогама чланова. Диференцијација пољопривредних, мешовитих и непољопривредних сеоских домаћинстава стога тече у правцу конвергенције ка градској породици базирајући опстанак на појединачном раду чланова, који стичу приходе изван села (Bobić М.,1999). Када је реч о економској структури домаћинстава према изворима прихода, 1961. године $26,5 \%$ домаћинстава у општини Панчево, имало је изворе прихода из пољопривреде, $16,7 \%$ је било мешовитих, а $56,7 \%$ непољопривредних домаћинстава. Насеља Банатско Ново Село и Долово у то време имала су преко 1000 домаћинстава којима је бављење пољопривредом било основни извор прихода за породицу (С3С, 1965r). Чланове домаћинстава са мешовитим приходима у највећем броју чинили су дневни мигранти са пољопривредним газдинством, уз додатни извор прихода у ванпољопривредним делатностима, представљајући уобичајену спону између села и града у то време. Beh 1971. године на нивоу Општине дошло је до знатног повећања удела домаћинстава са изворима прихода из непољопривредних делатности, док се удео домаһинстава са мешовитим изворима прихода двоструко смањио(СЗС,1974ђ). "Мала пољопривредна газдинства најпре су се претварала у мешовита домаћинства, а потом временом у непољопривредна. Њихово потпуно одвајање од пољопривреде је готово извесно уколико се ради о двопородичном 
домаћинству у коме се само старија генерација бави радом на земљи" (Петровић Р., 1979), У Панчеву је према Попису становништва из 1991. године било чак $89,7 \%$ непољопривредних домаћинстава, $5,2 \%$ пољопривредних и свега $3,3 \%$ домаћинстава са мешовитим изворима прихода (СЗС, 1995).

Пописни подаци из 2002. године пружају информацију како о економској структури домаћинстава према изворима прихода, тако и о домаћинствима са пољопривредним газдинствима. Од укупно 8.659 панчевачких домаћинстава са пољопривредним газдинством 2002. године, 986 или $11,4 \%$ било је са изворима прихода из пољопривреде, 6.775 или $78,2 \%$ са приходима из непољопривреде и свега 409 или $4,7 \%$ са приходима од рада пољопривредника и непољопривредника. Од суседних банатских општина, највише домаһинстава са мешовитим изворима прихода има релативно функцијски неразвијена општина Опово (12,3\%) (P3С,2004ф). Подаци о поседовању пољопривредног газдинства упућују да је у општини Панчево настављен процес повећавања броја непољопривредних домаћинстава. Тако је 2002. године удео домаћинстава без пољопривредног газдинства у укупном броју домаћинстава износио $80 \%$, што је за готово $10 \%$ више у односу на просек Војводине и у складу је са значајем Панчева као јаког индустријског центра у земљи. Преко $50 \%$ домаћинстава са пољопривредним газдинством 2002. године имала су само насеља Банатско Ново Село и Долово, у којима је пољопривреда и шездесетих година прошлог века била значајан извор прихода домаћинстава. Посебан проблем је велики број пољопривредних домаћинстава са једним чланом (1.066 или 12,3\%) на нивоу Општине, што упућује на актуелне проблеме недостатка радне снаге на пољопривредним газдинствима. Највеће промене у економској структури домаһинстава у претходном периоду одвијале су се у Старчеву. Савремене тенденције упуһују да је ово градско насеље у непосредној близини Панчева, и поред традиције у развоју пољопривреде, функционално све више оријентисано ка граду Панчеву попримајући карактер приградског насеља. У структури домаћинстава према поседовању пољопривредног газдинства, у периоду 1971-2002. година, удео непољопривредних домаћинства у укупном броју домаћинстава у Старчеву повећан је са $17,7 \%$ на чак $72,9 \%$.

Табела 37 . Промене структуре домаһинстава према поседовању пољопривредног газдинства (\% од укупног броја домаћинстава)

\begin{tabular}{|c|c|c|c|c|}
\hline \multirow[b]{2}{*}{ Територија } & \multicolumn{2}{|c|}{1971} & \multicolumn{2}{|c|}{2002} \\
\hline & $\begin{array}{c}\text { Пољопривредна } \\
\text { домаһинства }\end{array}$ & $\begin{array}{c}\text { Henoљопривредна } \\
\text { домаһинства }\end{array}$ & $\begin{array}{c}\text { Пољопривредна } \\
\text { домаһинства }\end{array}$ & $\begin{array}{c}\text { Непољопривредна } \\
\text { домаһинства }\end{array}$ \\
\hline Б. Брестовац & 85,9 & 14,1 & 48,6 & 51,4 \\
\hline Б. Hoso Ceno & 78,7 & 21,3 & 51,1 & 48,9 \\
\hline Гnorats & 66,6 & 33,4 & 45,6 & 54,4 \\
\hline Аолово & 82,0 & 18,0 & 55,5 & 44,5 \\
\hline Иваново & 77,0 & 23,0 & 38,1 & 61,9 \\
\hline Jaбyка & 59,3 & 40,7 & 41,9 & 58,1 \\
\hline Качарево & 61,9 & 38,1 & 26,5 & 73,5 \\
\hline Oмольича & 77,4 & 22,6 & 45,4 & 54,6 \\
\hline Панчево & 22,3 & 77,7 & 8 & 92 \\
\hline Cтарчево & 82,3 & 17,7 & 27,1 & 72,9 \\
\hline Опитина Панчево & 43,0 & 57,0 & 20,0 & 80 \\
\hline Војводина & 51,8 & 48,2 & 28,4 & 71,6 \\
\hline
\end{tabular}

Извор података:С $3 \mathrm{C}, 1974 \mathrm{~h} ; \mathrm{P} 3 \mathrm{C}, 2004 \mathrm{e}$.

Смањењу броја домаћинстава са пољопривредним газдинством у Панчеву допринело је и уситњавање пољопривредних поседа домаћинстава. У структури 
домаћинстава према величини поседа у последњих четрдесет година дошло је до изразитог смањења учешћа већих поседа, тако да највећи број домаћинстава располаже релативно малим поседима који најчешће служе само за задовољавање сопствених потреба за пољопривредним производима, а не као основни или допунски извор прихода домаћинства. Већина домаћинстава поседује мало газдинство величине 1-3 ha.

\section{6. Функционални развој и улога индустрије и стања на тржитту рада као детерминанти обима и територијалног домета дневних миграција}

Различита регионална и локална функционална структура и стање на тржишту рада најзначајније су детерминанте дневних миграција радне снаге у нашој земљи. Зато је за проучавање дневних миграција веома је важан однос између становништва и привреде ${ }^{15}$, имајући у виду да је "структура становништва динамичка категорија и да се мења у зависности од утицаја чиниоца који је опредељују" (Macura М., 1965). Просторна раздвојеност места рада и места становања најчешће је резултат немогућности локалне привреде да радно ангажује становништво одређених квалификација, или њених потреба за профилима занимања која нису у довољној мери заступљена у професионалној структури сопственог становништва. С обзиром на висок степен незапослености, као општи друштвени проблем у савременим условима транзиције привреде, дневне миграције активног становништва један су од начина превазилажења проблема незапослености у локалној средини. Потрага за запослењем у другом насељу један је од начина прилагођавања становништва неодговарајућим условима на локалном тржишту рада (немогућности за запослење или ниске зараде). Препрека већој дневној просторној покретљивости радника у Србији је недостатак стамбеног простора и ослањање на мрежу родбинских и пријатељских контаката у месту становања (Centar za visoke ekonomske studije, 2006).

Физичкогеографски и друштвеноекономски услови у којима се развијало Панчево утицали су на формирање и развој његових функција. Град Панчево је кроз историју био значајан занатски и трговачки центар и саобраһајно средиште. Настао је и развијао се првобитно као тврђава, односно са основном војном функцијом, да би се временом развиле и друге функције града и повећала њихова разноврсност. Данас је Панчево поред Зрењанина један од два највећа града Баната и значајан индустријски центар Србије. Стога су дневне миграције становништва као детерминанта дневног урбаног система Панчева у уској корелацији са привредним развојем самог града Панчева, како у оквиру општинске мреже насеља, тако и у ширем региону. Шири национални и регионални значај привреде, а нарочито панчевачке индустрије, одражава се на обим и правце дневних миграционих токова економски активног становништва на која знатан утицај имају велика индустријска постројења на простору општине Панчево. На то упућује и податак да је запосленост дневних миграната Панчева у индустријским делатностима била изнад просека за Војводину 2002. године. У извозу Баната 2002. године предњачи сектор индустрије (преко 95\% извоза су индустријски производи), чему $y$ највећој мери доприноси панчевачка индустрија (www.rpkpancevo.com). На простору Општине развијене су све привредне гране и то: пољопривреда, индустрија, грађевинарство, саобраћај, туризам и угоститељство, трговина, стамбено-комунална делатност, финансијске и друге услуге. Водећа област привређивања у Панчеву је индустрија, мада је све приметнији тренд пораста значаја сектора услуга.

\footnotetext{
${ }^{15} \mathrm{O}$ томе детаљније видети у раду М. Мацуре "Разматрања о односима између становништва и привреде" (1965).
} 
Пољопривреда - Велики удео пољопривредних површина $(84,6 \%)$ у укупној површини општине Панчево чини основу пољопривредне производње, која запошљава 1.700 радника Панчева. Допринос пољопривреде националном дохотку Панчева износи $13,2 \%$ а запослености $5,9 \%$. Значај пољьпривреде у укупном запошљавању на локалном нивоу није велики, али је ипак изнад националног просека. Удео запослених у пољопривреди није се битније мењао у периоду 1991-2002. година (5,2\% 1991. године), делимично услед смањења броја радних места у индустрији (смањење удела запослених у индустрији са $49,1 \%$ на $47,5 \%$ ). Упркос повољним природним условима, рад у пољопривреди обесхрабрује мала зарада, застарелост механизације, као и неповољна старосна структура сеоског становништва уз недостатак стручности. Структура поседа по величини показује да се пољопривредна производња одвија махом на парцелама мале величине (до 10 хектара) те да је оријентисана веһином на производњу за сопствене потребе. Структуру пољопривредних површина на простору Општине чине: обрадиве површине $93,6 \%$, пашњаци $3,4 \%$, рибњаци, трстици и баре $2,9 \%$. Анализа коришћења земљишта по врстама усева 2002. године показала је да је на (57.996 ha) или $90,8 \%$ ораница и башта 2002. године било засејано највише жито (пшеница и кукуруз) и индустријско биље (шеһерна репа, сунцокрет) (Р3С,2003). Од стоке највише се узгајају живина и свиње, уз приметан тренд смањивања сточног фонда на простору Општине. Гајењем жита и других усева и засада баве се: пољопривредно предузеће "Дунав" у Иванову, пољопривредно предузеће "Јабука" у Јабуци, пољопривредно предузеће "Качарево" у Качареву, предузеће Будућност ДIII - Банатско Ново Село, NICCO aграр из Банатског Брестовца, ПД Панжив у Омољици, Институт Тамиш - Панчево, предузеће Војводина ДІІП Старчево и др.

Иидустрија - Индустрија у Панчеву има дугу традицију. Први индустријски погон на простору Општине, Пивара, подигнут је 1722. године. Од укупно шездесет регистрованих индустријских предузећа у Банату 1910. године, чак четрнаест се налазило у Панчеву" (Томић П., Ромелић Ј., 2003). До Другог светског рата изграђ)ено је више индустријских објеката на простору Општине: Пивара, Фабрика стакла, Фабрика авиона, Фабрика сијалица Тесла, Фабрика скроба у Јабуци и др. После Другог светског рата развија се дрвна и графичка индустрија уз бржи развој металне и металопрерађивачке, прехрамбене (оснивање ПИК “Тамиш" 1963. године) и индустрије коже и обуће. У периоду 1960-1970. година изграђена су највећа предузећа на простору Општине. То су постројења Азотаре, изграђена 1962. године захваљујући повољним природним условима и локалном тржишту за вештачка ђубрива, и Рафинерије (изграђена 1970. године).

Панчево карактерише мала диверзификованост привредних капацитета. Највећи значај према броју запослених и уделу у формирању дохотка Општине има нафтнохемијска индустрија, са акцентом на преради нафте и производњи вештачких ђубрива. У Панчеву је један од три највећа комплекса хемијске индустрије у нашој земљи, поред Шапца и Обреновца. Азотара је 2005. године запошљавала 1.284 радника, док Рафинерија тренутно запошљава 2.200 радника (www.factis.co.yu;www.mp.co.yu).По броју радника које запошљава следи комплекс металне индустрије, производња неметалних минерала, а затим прехрамбена индустрија (Р3С,2003).

У структури индустрије Панчева заступљене су: базна и прерађивачка хемијска индустрија, прерада нафте и нафтних деривата, метална и електро индустрија, индустрија грађевинског материјала и стакла, прехрамбена индустрија, текстилна, индустрија коже и обуће, дрвна индустрија, графичка индустрија.

- Најзначајнија предузећа у области нафтно-хемијске индустрије на територији општине Панчево су НИС - Рафинерија нафте Панчево, "ХИП-Петрохемија", "ХИП-Азотара", "ХИП-Петромонт" "Индустрија 
хемијских производа "Панонија" и "Гаспетрол". Прерадом пластичних маса бави се већи број предузећа: "Пластхем-у ликвидацији", Медифарм пласт, Пан пласт. Производњом боја и лакова бави се предузеће Силекс из Панчева.

- Развој металопрерађивачке индустрије у Панчеву проистекао је из занатских радионица за израду пољопривредних алата и машина. После Првог светског рата у Качареву је основана машинска радионица из које је касније настало предузеће "Банат", од 1950. године под називом "Милан Премасунац", а које данас послује у оквиру "Утве". Најзначајнија предузеһа у Општини из домена металопрерађивачке индустрије су "Утва" и "Минел". Од некадашње фабрике једрилица и школских авиона "Утва" (1940. године пресељене из Земуна у Панчево) (Илиһ J., 1967) проширивањем производног асортимана основано је неколико фабрика које послују у оквиру "Утве" (пројектовање, производња и монтажа металних конструкција, производња процесне опреме и теретних возила и приколица). То су: "Утва-алуминијум", "Утва-проинг", "Утва-радник" и "Утва-возила". Производњом машина и уређаја баве се "Минелпрехрамбена опрема", и "Минел-опрема" (термоенергетска опрема), "ТЕСООР" Панчево и “АБЦ Инжењеринг" Панчево (производи машине и опрему за сточну храну). Ту су још и предузећа АЛ-Идеа - производња металних конструкција и Старчево Алкон - производња металних производа за грађевинарство Статуа Доо Старчево - ливење лаких метала(РЗС,2007a).

- Повољни природни услови омогућили су у Панчеву традиционално развијену индустрију грађевинског материјала (цреп, цигле). Индустрија стакла Панчево била је једна од три фабрике стакла у Србији (основана 1930. године и пуштена у рад 1932. године), у време када је подигнута у међупростору између Панчева и Војловице (Илић Ј.,1967). Индустрија стакла Панчево у реструктуирању једно је од највећих друштвених предузећа на простору Општине, док је ГИП АБ Конструктор АД Панчево друштвено предузеће средње величине. Овом делатношћу бави се и предузеће Павле Панчево - обликовање и обрада равног стакла (P3C,2007a).

- Прехрамбено-прерађивачка индустрија на простору Општине има дугу традицију (Пивара подигнута 1722. године, бројни парни млинови у насељима половином 19. века) (Илић J., 1967) засновану на квалитетним пољопривредним производима из окружења. На територији Панчева од прехрамбено-прерађивачке индустрије заступљене су: "Пекарска индустрија", млинска индустрија "Ратар", прерада воћа и поврћа "Тамиш-хладњача", прерада млека (млекара), прерада меса ("Агроживкомерц"), производња пива (EFES WEIFERT пивара), производња скроба и скробних деривата (фабрика скроба у насељу Јабука изграђена је давне 1897. године а данас послује као АД Индустрија скроба "Јабука"), производња готове сточне хране (предузеће Тимок из Банатског Новог Села) (Р3С,2007а). Близина Београда, као великог потрошачког центра знатно олакшава пласирање производа прехрамбене индустрије.

- Развој електротехничке индустрије у општини Панчево започиње изградњом фабрике сијалица Тесла 1931. године. Фабрика сијалица Тесла и даље је једно је од највећих предузећа на простору Општине. Године 1964. ова фабрика је учествовала са 40-50\% у укупној производњи 
сијалица у бившој Југославији (Илиһ J., 1967). Производњом сијалица и других уређаја за осветљење бави се и предузеће Макел електро ДОО Панчево (Р3С,2007a).

- Тридесетих година 20. века у Панчеву је подигнута Фабрика вештачке свиле, а затим је у Качареву основана фабрика за израду штофова и прераду вуне, а у насељима Старчево и Банатско Ново Село ваљаре за изаткано платно. Године 1937. основана је мала кудељара у Банатском Брестовцу, а 1939. године Прва подунавска предионица памучних предива "Трудбеник" у Панчеву (Илић J., 1967). Савремена текстилна индустрија представљена је фабрикама "Клупко" за производњу памучног, синтетичког и целулозног предива, "Новитет" (основан 1965. године) и "Банаһанка" (основана 1946. године са погоном и у Омољици од 1985. године). Производњом текстила баве се и предузећа "Знак" производња радне одеће, МП Модатекс ДОО Глогоњ - производња памучних тканина, Passage group ДОО Панчево и MGS TEX (P3C,2007a).

- Индустрија коже и обуће развила се из некадашьих занатских и кожарских радњи на простору општине Панчево. Најзначајнији објекти су приватизована Индустрија обуһе "Панчево" (формирана 1945. године) и бивша "Крзнара" Панчево - предузеће за прераду сирове коже и израду предмета од коже (основана 1953. године у саставу занатске задруге Панчевац), а након приватизације под називом Aries-Leather a.d. Pančevo.

- Прерада дрвета, графичка и новинско-издавачка индустрија. Дрвна индустрија у општини Панчево представљена је индустријом намештаја "Гај", (почела са радом још 1947. године) која се бави производњом кухињског намештаја, док се производњом плоча и табли од дрвета бави предузеће DOO TMB DIAMOND. Графичка индустрија на простору општине Панчево представљена је предузећима 6. Октобар штампарија АД Панчево и ДОО Дето Панчево. У овој групи предузећа су још и ЈНИП Панчевац - издавање новина, ДОО Витер - производња предмета од папира и ДОО Фимпак -производња таласастог папира и амбалаже (P3C,2007a).

Привредни и индустријски развој Панчева утицао је на демографски и функционални развој насеља Општине а тиме и на правце дневних миграција економски активног становништва. Највећи број радника ради у индустријској зони формираној на подручју Азотаре и Рафинерије. Просторни размештај индустрије по насељима показује да се индустријска делатност на простору општине Панчево обавља у 42 индустријско-просторне јединице, од чега је 36 у граду Панчеву, две у Јабуци и по једна у Качареву, Омољици, Банатском Новом Селу и Банатском Брестовцу (Милетић Р.,1999). Остала насеља општине Панчево одликује слаба функционална диверзификованост (доминација функције становања) и функционална зависност од центра Општине. Услед рада бројних индустријских постројења, а нарочито комплекса нафтно-хемијске индустрије, у граду Панчеву изражена је загађеност животне средине, па је жеља за бољим еколошким условима живота један од могућих фактора утицаја на правац токова дневних миграција. Када се остваре финансијски услови и када становништво почне да више цени мање индустријализована и урбанизована насеља за породични живот, могуће је очекивати пораст обима дневних миграција правца сеоска насеља општине Панчево-град Панчево, као и евентуална дефинитивна пресељења у обрнутом смеру. Да би се то остварило поред развоја еколошке свести потребно је и да се испуне финансијски услови, тј. да висина зараде може да поднесе трошкове 
свакодневног путовања. У том случају радници би мењали дефинитивну миграцију дневном како би живели у насељима погоднијим за породични живот, са мање буке и загађења. Побољшање квалитета животне средине тако је један од услова за останак становника у Панчеву.

Саобраһај, занатство, трговина и туризам - Највеће саобраћајно предузеће у општини је Аутотранспорт Панчево основано још 1948. године. Водени теретни саобраћај одвија се преко Луке "Дунав". Занатство је било раније веома развијено у Панчеву (вуче корене од почетка 18. века), али су снажан развој индустрије и одсељавање Немаца после Другог светског рата утицали на смањење броја занатских радњи и запослених у занатству. Немци су били познати као занатлије.“... 1764. године, у српском Панчеву је од 176 домаћинства било 12,3\% занатских домаћинстава, а у немачком Панчеву од укупно 70 домаһинстава $58,6 \%$ занатлија". Туризам је споредна грана привреде у Панчеву и остварује приход претежно од пословних посета и ловног туризма, пре свега због тога што у Општини доминирају измењени и еколошки неповољьи услови живљења (Универзитет у Новом Саду, ПМФ-Институт за географију, 1996). У Панчеву је традиционално развијена трговина, која вуче корене из трговине стоком и житом у првој половини 19. века. Трговини је у то време погодовала веома богата пољопривредна околина и саобраһајне везе пловним Тамишем и Дунавом. Положај Панчева на контакту аграрне регије Баната и Београда, као великог потрошачког центра, чини повољне предуслове за развој трговине. Највеће предузеће које се бави трговином је друштвено предузеће"Тргопродукт". Осим трговинских предузећа у граду Панчеву регистрована су предузећа која се баве трговином на велико још у неким насељима Општине. То су: "Дидима" у Долову и предузеће "Агриленд"Јабука за посредовање у продаји пољопривредних сировина (РЗС,2007а).

Међу осталим (непривредним) функцијама за обим и правце дневних миграција Панчева значајне су:

Просветиа функција - Просветно-културна функција града Панчева има дугу традицију. Према Илићу средње школе стварају функционалне односе првог (мања територија), а више школе другог (већа територија) степена. Панчево је одувек било значајан школски центар Баната. Најзначајнија школска установа била је Панчевачка гимназија, која и данас важи за средњошколску установу са високим нивоом наставе. У образовању је 2002. године било запослено 5,6\% становништва Панчева. Као показатељи развијености просветне функције у Панчеву приказани су број ученика и студената, и школа. Панчево је 2002. године имало 19 основних (11.641 ђака), 8 средњих школа (5792 ђака), и 6 специјалних школа (142 ђака). Од укупно 8.087 предшколске деце на простору Општине, у 25 предшколских установа боравило је 2002. године 2.739 или $33,8 \%$ деце (РЗС,2003). Укљученост деце у неки облик предшколског васпитања веома је значајан за економску активност жена и њихово учешһе у дневној миграцији.

Према подацима за школску 2001/2002. годину највише уписаних ученика у Банату било је у Панчеву када је реч о основним, и Зрењанину када је реч о средњим школама. Од суседних општина, општине Опово и Пландиште немају средњу школу, а Алибунар има само једну средњу школу, што се одражава на токове дневних миграција ученика ка Панчеву. У Банату генерално недостају високошколске установе, а што је најизраженије у јужнобанатском округу. Високо и више школство у Банату је представљено са два факултета (Зрењанин, Кикинда) и три више школе. На простору Јужно-банатског округа постоји само једна виша школа у Вршцу (Р3C,2005a). Подаци о високошколским установама су индикативни и указују да су средњошколци Панчева упућени да иду на студије ван региона, најчешће у Београд или Нови Сад као центре високог школства. 
Поред везе која постоји између броја и структуре школских установа у Панчеву и обима и праваца дневних миграција ученика и студената, систем образовања у Општини повезан је и са тржиштем рада делујући на структуру радне снаге. Као резултат структурне незапослености, тј. неподударности понуде и потражње за радном снагом различитих квалификација, долази до појаве дневних миграција радника. Стоra систем образовања мора да се прилагођава променама у економији, како би се успешно задовољиле потребе привреде за радном снагом различитих профила.

Здравствена функција - Панчево има дугу традицију развоја здравствених установа. По броју запослених у подсектору здравства 2002. године (2.700 или $9,9 \%$ од укупног броја запослених становника Панчева) види се да се здравству посвећује велика пажња. За здравље животиња задужена је Ветеринарска станица 300 Центар (P3C, 2003;P3C,2007a).

Административно управиа функција - У турском периоду Панчево је било паланка и седиште санџака и нахије (Универзитет у Новом Саду, ПМФ-Институт за географију, 1996). Године 1782. увођењем кантонског административног система, Панчево постаје седиште кантона, са дистриктима у Панчеву, Перлезу, Ковину и Алибунару. Након Првог светског рата 1921. године Град улази у састав Београдске области. Осим градских припадале су му и среске и жупанијске управне власти 1925. године. Од 1931. године Панчево улази у састав посебне административне јединице Управа града Београда, Панчева и Земуна. Административно-управна функција Панчева датира још из периода постојања Панчевачког среза који је постојао од 1921. до 1965. године, имао 46.954 становника и обухватао 13 насеља. У граду Панчеву у то време су биле бројне среске установе, као и средиште Окружног суда под чију су принадлежност спадали још срезови Алибунар, Ковачица и Ковин (Илиһ Ј.,1967; www.pancevo.co.yu). Панчево је данас средиште Јужнобанатског округа и врши функције које произилазе из улоге средишта општине и округа. Територијалноадминистративну структуру Јужно-банатског округа поред Панчева чини још седам општина (Алибунар, Бела Црква, Вршац, Ковачица, Ковин, Опово и Пландиште).

\section{Стање и прочеси на тржсииту рада}

Процеси који се одвијају на локалном и на регионалном тржишту рада директно се одражавају на обим и токове дневних миграција активног становништва. Актуелно стање на тржишту рада Панчева резултат је наслеђених услова али и промена које се одвијају протеклих година у условима транзиције локалне и регионалне привреде. Структура запослености према величини предузећа и доминатна запосленост у великим предузећима отежава промене на локалном тржишту рада. Ради бољег увида у стање и кретања на панчевачком тржишту рада извршена ја анализа распореда националног дохотка и броја запослених по секторима делатности.

У великој мери захваљујући висини дохотка општине Панчево (који чини $54 \%$ од укупног дохотка Јужно-банатског округа) национални доходак Јужно-банатског округа једнак је заједничком националном дохотку Северно-банатског и Средњебанатског округа (РЗС, 2003). Анализа трендова везаних за учешће појединих делатности у укупном националном дохотку и ангажованом броју запослених значајна је с обзиром да различите делатности привлаче радну снагу са различитих удаљености, а у зависности од структурне (не)једнакости понуде и потражње за радном снагом, и висине зараде која се у оквиру одређене делатности може зарадити. Генерално је прихваћено становиште да делатности са већим зарадама привлаче раднике са већих удаљености и обрнуто. Ако се анализира распоређеност националног дохотка по секторима делатности може се уочити да је индустрија у Панчеву најзначајнији сегмент 
привреде. Индустрија запошљава $53,6 \%$ свих запослених и учествује са $56 \%$ у формирању дохотка привреде Општине, односно чини $11 \%$ дохотка Војводине из индустрије (Р3С, 2003). После доминантног сектора производње/индустрије, други по снази у формирању дохотка општине Панчево је сектор услуга, док је тек на трећем месту сектор пољопривреде, с обзиром да је реч о Општини чији је центар један од већих српских градова. Учешће пољопривреде у националном дохотку Панчева знатно је ниже од просека за Банат и Војводину. С друге стране сектор услуга, мада испод просека за Србију, развијенији је у Општини него на нивоу Баната као ширег региона.

Табела 38. Распоред националног дохотка по секторима делатности 2002. године (\%)

\begin{tabular}{|l|c|c|c|}
\hline \multicolumn{1}{|c|}{ Територија } & Пољопривреда & Индустрија & Устуге \\
\hline Опитина Панчево & 13,2 & 55,9 & 30,9 \\
\hline Банат & 26,0 & 51,6 & 22,3 \\
\hline Војводина & 25,3 & 46,1 & 28,4 \\
\hline
\end{tabular}

Извор: Р3C,2003.

Пораст значаја услужних делатности у формирању дохотка Општине, на рачун индустрије и пољопривреде, започео је од седамдесетих година прошлог века. У структури дохотка по делатностима 1971. године, на првом месту у Панчеву налазила се индустрија са $58,6 \%$, затим услуге са $23,7 \%$ и пољопривреда са $17,6 \%$. Расподела националног дохотка из 1970. године показује да је и у то време пољопривреда учествовала у формирању дохотка Општине знатно испод просека за Банат, док је сектор услуга био у рангу учешћа сектора услуга у формирању дохотка Баната (Томић П., Ромелић Ј., 2003).

Општина Панчево запошљава највећи број радника Јужно-банатског округа. На другом месту по броју запослених налази се општина Вршац са знатно мањим бројем ангажованих радника (7.843). Од укупно запослених 28.889 радника у Панчеву 2002. године, без лица која самостално обављају делатност, у привреди и ван привреде било је $83,1 \%$ радника (21.860 у привреди, и 7.029 ван привреде). Радници који самостално обављају делатност чинили су $16,9 \%$ од укупног броја запослених. При анализи секторске структуре запослености у Панчеву, према подацима за 2002. годину, уочава се чињеница да је највећа запосленост у индустрији, која обухвата више од половине запослених у Општини (53,6\%), потом у сектору услуга са $40,5 \%$ и пољопривреди са $5,9 \%$ (Р3С,2003). Када се подаци пореде са Банатом и Војводином може се констатовати да је на нивоу Панчева знатно више запослених у индустрији а мање у пољопривреди што је и логично имајући у виду индустријску оријентацију Панчева.

Табела 39. Запослени по секторима делатности 2002. године (\%)

\begin{tabular}{|l|c|c|c|}
\hline \multicolumn{1}{|c|}{ Територија } & Пољопривреда & Индустрија & Устуге \\
\hline Опитина Панчево & 5,9 & 53,6 & 40,5 \\
\hline Банат & 13,2 & 47,8 & 39,0 \\
\hline Војводина & 11,7 & 44,4 & 43,9 \\
\hline
\end{tabular}

Извор: Р3С, 2003.

У структури запослених по секторима делатности на простору општине Панчево промене се одвијају у правцу слабљења улоге индустрије и генералног смањења броја запослених у делатностима које се баве производњом, док се повећава број запослених ангажованих у терцијарно-квартарним делатностима и удео лица која самостално обављају делатност. И поред овог тренда удео лица која самостално обављају делатност у укупном броју запослених на простору Општине (16,9\%) био је мањи 2002. године у односу на просек за Војводину $(22,6 \%)$ и Србију $(21,1 \%)$. У периоду 1990-2002. година допринос сектора услуга укупној запослености повећан је како у Банату, тако и у целој 
Војводини и Србији, с тим да је у Србији то било у нешто већој мери (РЗС 1992a;Р3С,2003). И у будућности се може очекивати бржи раст сектора услуга у односу на производни, с обзиром на текући процес транзиције привреде и убрзан развој тржишне економије. Пораст запошљавања у терцијарном сектору резултат је растућих потреба становништва и привреде за разним услугама. Услужне делатности стога he имати повећану потражњу за радном снагом, за разлику од индустрије где ће нестати потреба за бројним пословима. Смањење броја запослених у сфери услуга може се очекивати само у случају образовања и здравства, због текуће транзиције државних установа. Све ове промене пратиће власничко и производно преструктуирање индустријских капацитета Општине и убрзан развој малих и средњих предузећа у наредном периоду.

Када је реч о структури запослених по подсекторима, може се уочити да је запосленост у Панчеву 2002. године била највећа у области индустрије (13.711 или $47,5 \%$, запослених) потом у подсектору здравства и социјалне заштите (2.700 или 9,9\% запослених), затим у трговини (2.202 или 7,6\% запослених), саобраһају складиштењу и везама (2.075 или 7,2\% запослених), сектору пољопривреде (1.709 или 5,9\% запослених), образовању (1.632 или 5,6\% запослених), грађевинарству (1.172 или 4\% запослених), државној управи и социјалном осигурању (828 или 2,9\% запослених), финансијском посредовању ( 808 или $2,8 \%$ запослених), енергетици и водоснабдевању (618 или $2,2 \%$ запослених). Од осталих општина Јужно-банатског округа истичу се општине Опово и Пландиште са великим уделом запослених у пољопривреди, а општине Бела Црква и Ковин са више од половине запосленог становништва у сектору услуга (РЗС,2003).

Истраживање регионалних карактеристика тржишта рада Србије (Centar za visoke ekonomske studije, 2006), обављено 2004. године са циљем оцене стања и перспектива на тржишту рада у Србији и издвајања региона у којима су припадници радне снаге изложени изнадпросечном ризику од незапослености, извршено је на основу три врсте индикатора. То су:

- индикатори опште економске ситуације,

- индикатори услова на тржишту рада, и

- индикатори прогреса у транзицији и привредном реструктуирању.

Према укупном композитном индексу, на основу кога је могуће дефинисати релативне позиције сваког региона у поређењу са националним просеком и осталим регионима, Јужно-банатски регион (заједно са Браничевским, Шумадијским, и Поморавским) налази се у групи региона за које се вредности овог показатеља крећу од 0,8 до 3,4 . Од ове групе региона развијенији су само Северно-бачки, Јужно-бачки, Београдски и Нишавски регион. Груписање региона, у односу на општи просек, према групним индексима стања и перспектива показало је да се Јужно-банатски округ налази на првом месту у четвртој категорији са позитивним наслеђеним условима и постојећом ситуацијом али негативним потенцијалима за будуће промене. Према типологији општина на основу укупног композитног индекса стања и перспектива на тржишту рада панчевачка општина налази на шеснаестом месту у Србији (Centar za visoke ekonomske studije, 2006).

Оцена стања и перспектива на тржишту рада у Панчеву извршена је у складу са проучавањем тржишта рада Србије у организацији Центра за високе економске студије (Centar za visoke ekonomske studije, 2006), а на основу доступних података у вези са одговарајућим индикаторима. Показатељи опште економске ситуације у општини Панчево 2002. године, националии доходак по глави становника, и удео непољопривредног становниитва у укупном, имали су вредности изнад просека за 
Војводину, док је стопа неписмености (као индикатор општег нивоа образованости становништва) у Панчеву била нешто веһа $(2,7 \%)$ у односу на просек Војводине $(2,5 \%)$, што се негативно одражава на тржиште рада. Народни доходак по становнику, износио je 2002. године 171,8 (ниво PC $=100$ ), позиционирајући општину Панчево на друго место у Војводини по висини дохотка, после општине Апатин. У структури дохотка Војводине Општина је учествовала са $6,2 \%$ а Јужно-банатског округа са $38,8 \%$. Већи доходак 2002. године у Србији имале су само београдске општине Нови Београд, Стари Град и Врачар (Р3С,2003a).

Друга група индикатора услова на тржишту рада обухвата индикаторе наслеђених услова и текуће ситуације и потенцијала за потивне промене. У Панчеву је 2002. године стопа незапослености (као индикатор наслеђених услова) износила $16,1 \%$ (161 незапослено лице на 1000 становника), од чега је $56,4 \%$ било жена. Повољнији однос незапослених мушкараца и жена на ширем регионалном нивоу упућује на веће проблеме приликом проналажења запослења за женску популацију Панчева (Р3С,2003a). На евиденцији Националне службе за запошљавање 2005. године у Јужнобанатском округу је било 41.938 лица која траже посао, од чега $18.151(43,2 \%)$ у Панчеву. Највећи број незапослених лица био је старости између тридесет и четрдесет година. Удео лица на простору Општине која по први пут траже запослење је висок и износи $71,9 \%$ иако неке суседне општине имају и веһи удео младих лица без радног искуства у структури незапослених (Опово 87\%, Алибунар 76\%) (rztr.co.yu;P3С,2006) .

Иако је 2002. године општина Панчево имала највише запослених на 1000 становника у Јужно-банатском округу, период од 1991 до 2002. године карактерише смањење обима запослености на простору Општине са 41.290 на 34.771 (укључујући и лица која самостално обављају делатност) и пораст броја незапослених лица са 14.242 на 20.499 (РЗС 1992а;Р3С,2003). У овом периоду досељавање је највише допринело порасту броја становника Општине, тако да је и поред негативног природног прираштаја удео радно способног у укупном становниитву Панчева (као потенцијал за позитивне промене на тржишту рада) већи од просека за Војводину и Србију као целину $(66,9 \%$ на према $65 \%$, односно $64 \%)$. Понуда радне снаге - удео младог становниитва (испод 18 година старости) у укупном становништву такође показује потенцијал за позитивне промене на тржишту рада. Суседне општине Ковин, Ковачица, Алибунар и Опово имају већи удео младих до 18 година старости у укупном становништву од Панчева (19,4\%). Просечне зараде по запосленом 2002. године у општини Панчево, као један од индикатора стања на тржишту рада, биле су изнад просека Војводине и Србије (РЗС,2003).

Tpeha група индикатора стања на тржишту рада, која показује прогрес у реформама и економском реструктуирању, нема повољне вредности за општину Панчево. Удео приватног сектора у укупном народном дохотку, као један од показатеља брзине реформи, у Панчеву је 2002 . године износио $30,6 \%$, што је знатно мања вредност показатељьа у односу на просек Округа $(36,2 \%)$ и Војводине $43,6 \%$. Ово је резултат незавршеног процеса приватизације и трансформације привреде. У прерађивачкој индустрији било је запослено чак $47,5 \%$ од укупног броја запослених на простору општине Панчево 2002. године. Удео запослених у главној грани делатиости користи се као мера диверзификације привреде. "Унификација потенцијала запослености не представља позитивну пожељну особину тржишта рада" (Centar za visoke ekonomske studije, 2006). Мала диверзификованост привреде онемогућава адекватну апсорпцију радних потенцијала образовних кадрова, што се одражава на правце дневних миграција. Најмање диверзификовану привреду од општина са којима Панчево дневно размењује радну снагу имају општине Раковица и Смедерево које су такође изразито индустријски оријентисане. Удео запослених у држсавном $(83,1 \%)$ u 
приватном сектору $(16,9 \%)$ показатељ је прогреса у реформама на тржишту рада (P3C, 2003).

Трансформације и реформе привреде на националном нивоу одражавају се на повећање броја радника који остају без посла и на простору општине Панчево. Овом процесу делимично доприноси и раније стварање непродуктивних радних места и дуго одржавање социјалне улоге предузећа у нашој земљи. У датим условима може се очекивати даље смањење обима запослености у индустрији, нарочито након реформи великих индустријских предузећа на простору Општине, а имајући у виду мали степен диверзификације привреде Панчева и мали број запослених у приватном сектору делатности. Ови процеси неминовно ће се одразити на дневне миграционе токове радне снаге Панчева.

У наредном поглављу извршена је анализа коневергентних и дивергентних токова радника и ученика/студената у дневном урбаном систему Панчева. Циљ је да се утврди које карактеристике радне снаге узрокују оријентацију ка граду Панчеву или другим локацијама. 


\section{IV КОНВЕРГЕНТНЕ И ДИВЕРГЕНТНЕ ДНЕВНЕ МИГРАЩИЈЕ РАДНИКА, УЧЕНИКА И СТУДЕНАТА ДНЕВНОГ УРБАНОГ СИСТЕМА ПАНЧЕВА}

\section{1. Просторна димензија дневног урбаног система и дефинисање функционалног подручја Панчева}

Дневне миграције, као посебан облик просторне покретљивости становништва, покреће двосмерна интерактивна веза између становништва и насеља рада и становања указујући на то докле се протеже функционално дејство града тј. до које мере град привлачи становништво насеља у његовој околини. Учесталост и интензитет дневних миграција утиче на регионалну интеграцију функцијски, економски и физиономски хетерогеног простора (Тошић Д., 1999). Дефинисање функционалног подручја Панчева и његовог дневног урбаног система омогућено је анализом функционалних веза између града Панчева и околине које се манифестују преко дневних миграција становништва.

Од укупног броја становника општине Панчево 2002. године свакодневно је у друго насеље на посао или у школу путовало 18.690 или $15 \%$ становништва. Од тога су две трећине $(68,6 \%)$ била активна лица која обављају занимање и једна трећина школска омладина и студенти $(5.876$ или $31,4 \%)$. У поређењу са просеком за Србију (без Косова и Метохије) међуопштинске дневне миграције у Панчеву су нешто мање изражене док су више заступљена дневна кретања становништва локалног карактера, у првом реду захваљујући привлачном деловању јаког индустријског општинског центра. У структури токова дневних миграција општине Панчево локалне миграције активног становништва учествују са $66,1 \%$, а међуопштинске са $33,2 \%$ (P3С,2004a).

На основу посебно обрађених података Пописа становништва из 2002. године, а од стране Републичког завода за статистику Србије, дневне мигранте Панчева чине: радници (16.355 или $70,8 \%)$, и ученици и студенти (6.748 или $29,2 \%)$. Ако се дневне миграције посматрају као конвергентне, са тежиштем на простору запослења, простор Општине је конвергентно подручје за (14.619 или 63,3\% дневних миграната), а ако се дневне миграције посматрају као дивергентне са простора становања, односно са тежиштем на простору становања, простор општине Панчево је дивергентно подручје за (8.484 или $36,7 \%$ дневних миграната). На простор Општине свакодневно долази 3.533 радника и 884 ученика из других општина, а напушта га због рада/школовања 4.341 радник и 4.143 ученика/студента. У локалним дневним миграцијама, које се одвијају у оквиру простора општине Панчево, учествују 8.482 радника и 1.721 ученик. Удео радне снаге који ради у свом насељу становања износи $70,4 \%$ за Општину као целину.

Простор општине Панчево прима дневне мигранте са територије 31 општине (129 насеља) укључујући и насеља општине Панчево. Локални дневни мигранти (чије се место полазишта и одредишта налази унутар граница простора општине Панчево) и дневни мигранти из београдских општина чине $80,7 \%$ од обима дневних миграција. Тридесет два насеља (укључујући и насеља општине Панчево) дају $95 \%$ конвергентних дневних миграната општине Панчево. Сва насеља општине Панчево су миграционо активна у односу на општински центар. Насеља из којих долази највећи број дневних миграната Панчева су општинска насеља Старчево и Јабука. Од суседних општина највећи број дневних миграната долази из насеља Баваништа, Мраморка и Ковина у општини Ковин, и Црепаје у општини Ковачица.

Токови дивергентних дневних митрација са простора Општине крећу се према 23 општине и 70 насеља. Приметно је да је број насеља чије становништво учествује у дневним миграцијама већи када је реч о доласцима у односу на одласке. Ка осамнаест 
општина креће се 97\% дивергентних дневних миграната општине Панчево. Највећи број дневних миграната путује ка београдским општинама и другим суседним општинама: Алибунар, Ковачица и Ковин. У неку од београдских општина путује чак $90,5 \%$ дневних миграната Панчева.

Двадесет насеља прима 95\% дивергентних дневних миграната општине Панчево. Насеља у која одлази највећи број дневних миграната Панчева су општинска насеља Старчево и Јабука. Када је реч о суседним општинама највећи број дневних миграната путује у насеља (Алибунар, Ковачица, Ковин и Падинска Скела) у некој од суседних општина.

Табела 40. Дивергентни дневни мигранти општине Панчево према општини рада 2002.године

\begin{tabular}{|l|c|c|}
\hline \multicolumn{1}{|c|}{ Општина } & $\begin{array}{c}\text { Број дневних } \\
\text { миграната }\end{array}$ & $\begin{array}{c}\mathbf{Y}_{\text {део }} \\
(\%)\end{array}$ \\
\hline $\begin{array}{l}\text { Непозната } \\
\text { београдска општина }\end{array}$ & 5.520 & 64,6 \\
\hline Палилула & 475 & 5,6 \\
\hline Стари Град & 376 & 4,4 \\
\hline Савски Венац & 334 & 3,9 \\
\hline Земун & 331 & 3,9 \\
\hline Звездара & 210 & 2,5 \\
\hline Нови Београд & 177 & 2,1 \\
\hline Врачар & 155 & 1,8 \\
\hline Вождовац & 141 & 1,7 \\
\hline Алибунар & 121 & 1,4 \\
\hline Ковачица & 119 & 1,4 \\
\hline Ковин & 76 & 0,9 \\
\hline Чукарица & 67 & 0,8 \\
\hline Вршац & 50 & 0,6 \\
\hline Нови Сад & 29 & 0,3 \\
\hline Опово & 28 & 0,3 \\
\hline Зрењанин & 24 & 0,3 \\
\hline Раковица & 15 & 0,2 \\
\hline Гроцка & 9 & 0,1 \\
\hline Укупно Београд & 7.678 & 90,5 \\
\hline
\end{tabular}

Извор података: Р3С,2007 Посебна обрада података.

Ако се посматра тип насеља полазишта дневних миграната општине Панчево, већина дневних миграната долази из насеља која нису градска по типу ( 8.800 или $60,2 \%$ ), док из градских насеља долази 5.819 или $39,8 \%$ дневних миграната. Дивергентни токови дневних миграција општине Панчево усмерени су ка градским насељима $7.111(83,8 \%)$, а ка осталим насељима $1.373(16,2 \%)$. Из градских насеља на простор општине Панчево долази 4.999 активних дневних миграната $(41,6 \%)$ и 820 ученика $(31,5 \%)$. Из сеоских насеља је $7.015(58,4 \%)$ активних дневних миграната и $1.785(68,5 \%)$ ученика. Може се закључити да ученици дневни мигранти долазе на простор Општине већином из сеоских насеља, док разноврсне функције Панчева привлаче како раднике који живе у градским, тако и раднике који живе у сеоским насељима. Од укупног броја дивергентних дневних миграната са простора Општине $4.076(98,4 \%)$ ученика/студената, и 1.635 (37,7\%) активних дневних миграната иде свакодневно да ради/школује се у насељима ван граница Општине, која су градска по типу. У насеља ван граница Општине која нису градска по типу свакодневно путује свега 180 или 4,1\% радника, док је за велики број радника (2.526) тип насеља рада 
непознат (од тога 2.376 радника ради у непознатој београдској општини). Из града Панчева свакодневно на посао у остала насеља Општине путује 216 радника. Од тога у градска насељь путује $48,1 \%$ дневних миграната, од чега највише у Јабуку.

Најјачи центар, како конвергентних, тако и дивергентних токова дневних миграпија је насеље Панчево, које прима 14.166 дневних миграната (од чега 9.855 локалних дневних миграната и 4.311 дневних миграната са простора других општина) и даје 6.003 дневна мигранта. Град Панчево има позитиван гравиташиони биланс првенствено захваљујући апсорпцији локалних дневних миграната. Према односу континуиране дневне миграпије становништва коју прима и даје Панчево припада групи апсорпционо-дисперзивних градова, тј оних који имају већу апсорпцију дневне митрапије у односу на дисперзију. ${ }^{16}$

На карти бр.6 приказана су места полазишта 99\% конвергентних дневних миграната града Панчева. Највећи број дневних миграната долази из београдских ошштина (претежно из Палилуле и Новог Београда) и суседних банатских општина: Ковин, Ковачица, Алибунар и Опово.

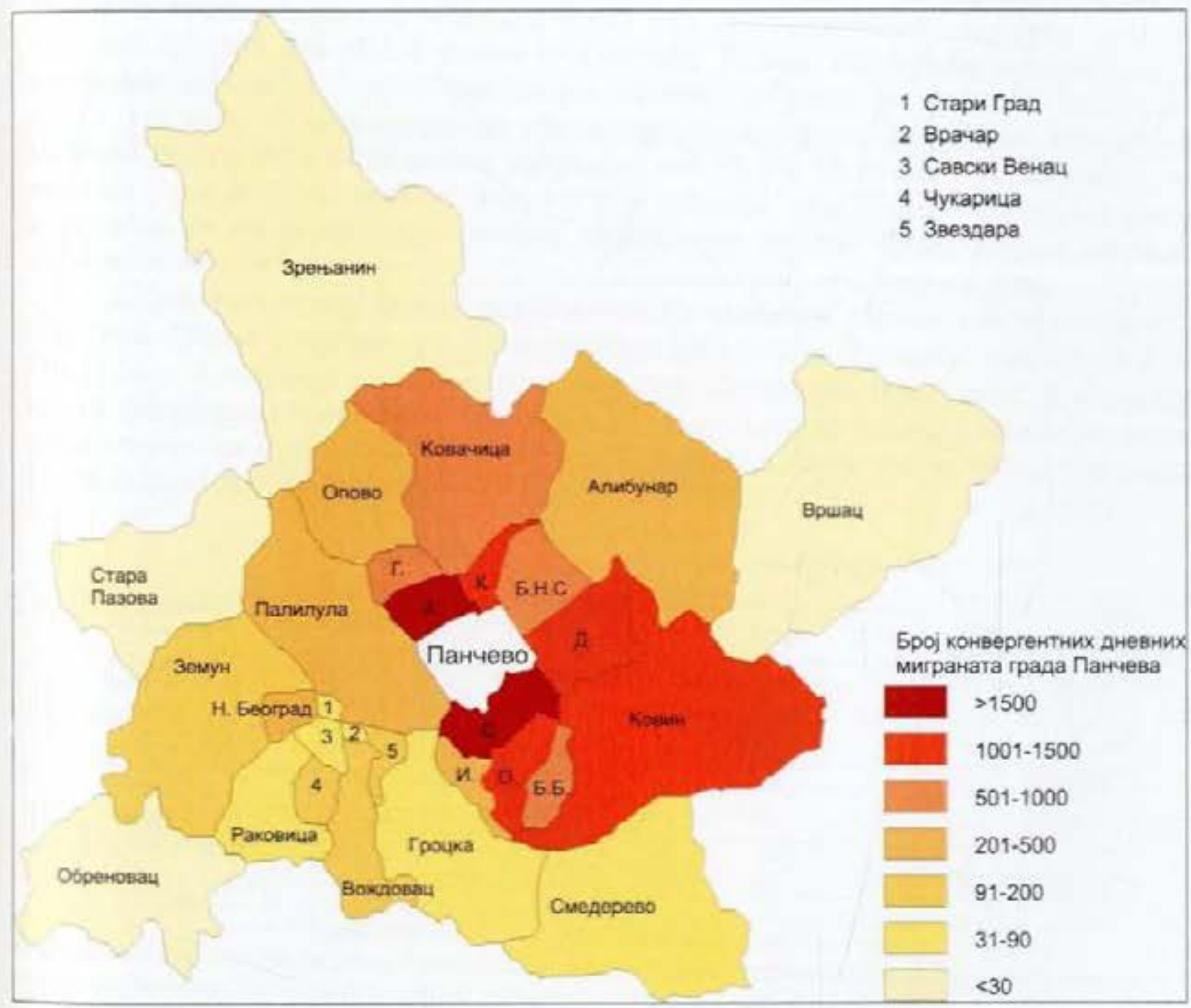

Карта 6. Конвергентни дневни мигранти Града Панчева 2002. године Извор података: Р3С,2007 Посебна обрада података.

Види Стаменковић С., Бачевић М., 1992. 
"Нето стопа дневне миграције представља један аспект функционалних веза измећу града и околине и мера је дневног прилива радне снаге у град. Други аспект јесте стопа дневне миграције из периферије ка граду" (Үu Е.Y., 1972). За град Панчево нето стопа дневне миграције, која показује степен у коме је главни град овисан од радника који живе ван њега - да попуне његова слободна радна места, износи $31,9 \%$. Вредност другог показатеља - стопе дневне миграције из предграђа у град, која показује обим у коме предграђе зависи од послова у главном граду да снабдеју његову радну снагу, за Панчево износи $50,8 \%$. Ове две стопе мере различите аспекте функционалне међузависности између града и околине.

Просторна дисперзија дневних миграната Панчева (радника и ученика/студената) може се сагледати на основу размештаја насеља која дају и примају дневне мигранте у оквиру изотела повучених на сваких 10 километара удаљености од Панчева. Број миграционо активних насеља и обим дневне миграције разврстани су у седам просторних зона, при чему максимални просторни домет чини изотела од $60 \mathrm{~km}$ удаљености. С обзиром да конвергентни и дивергентни токови дневних миграција већином нису симетрични сагледана су и продискутована оба аспекта. У дневним миграцијама највише учествује становништво из трећег просторног круга односно оних насеља која се налазе на растојању од 20 до 30 километара од Панчева (13.883 или $68,8 \%$ дневних миграната). Од тога 4.193 или $30,2 \%$ дневних миграната долази у Панчево, и 9.690 или $69,8 \%$ одлази из Панчева. Велики обим дивергентних дневних миграција обухваһен овим просторним кругом резултат је локације Београда у поменутој зони. Становништво из другог просторног круга у дневним миграцијама Панчева учествује са 6.764 дневна миграната или $33,5 \%$. Из ове просторне зоне путује највише конвергентних дневних миграната, и већи део чине локалне дневне миграције, с обзиром на наглашену привлачност општинског центра. Обим дневне миграције смањује се са повећањем просторне раздвојености насеља становања и рада.

Поред тога што је центар рада/школовања за дневне мигранте из других насеља Општине, Панчево привлачи и становништво Београда и суседних општина Ковина, Ковачице и Алибунара са којима постоји добра саобраћајна повезаност. У структури токова спољашњих дневних миграција према граду Панчеву токови дневних миграција становништва са простора општина Ковин, Ковачица и Алибунар чине $54,1 \%$, односно $46,2 \%$ за активно становништво.

Табела 41. Радијус кретања дневних миграната Града Панчева 2002. године

\begin{tabular}{|c|c|c|c|c|c|c|c|c|c|}
\hline \multicolumn{2}{|c|}{$\begin{array}{l}\text { Удаљеност од } \\
\text { Панчева }(\mathrm{km})\end{array}$} & Ao 10 & $10-19$ & $20-29$ & $30-39$ & $40-49$ & $50-59$ & $\begin{array}{l}60 \text { n } \\
\text { више }\end{array}$ & Укупно \\
\hline \multirow{2}{*}{$\begin{array}{c}\text { Конвергентии } \\
\text { Аневни } \\
\text { мигранти }\end{array}$} & Бpo] & 1.996 & 6.520 & 4.193 & 1.070 & 177 & 76 & 114 & 14.166 \\
\hline & $\%$ & 14,1 & 46,0 & 29,6 & 7,5 & 1,2 & 0,5 & 0,8 & 70,2 \\
\hline \multicolumn{2}{|c|}{ Epoj Hacesa } & 1 & 8 & 21 & 20 & 25 & 18 & 36 & 129 \\
\hline \multirow{2}{*}{$\begin{array}{c}\text { Дивергентни } \\
\text { дневни } \\
\text { мигрантм }\end{array}$} & Бpoj & - & 244 & $5.478 *$ & 98 & 15 & 7 & 117 & 6.003 \\
\hline & $\%$ & - & 4,1 & 91,2 & 1,6 & 0,2 & 0,1 & 1,9 & 29,7 \\
\hline \multicolumn{2}{|c|}{ Број насеља } & $\cdot$ & 3 & 17 & 11 & 10 & 3 & 26 & 70 \\
\hline \multirow{2}{*}{ Укупно } & Epoj & 1.996 & 6.764 & $9.671 *$ & 1.168 & 192 & 83 & 251 & 20.169 \\
\hline & $\%$ & 9,8 & 33,5 & 47,9 & 5,8 & 0,9 & 0,4 & 1,2 & 100,0 \\
\hline
\end{tabular}

Извор података:Р3С, 2007 Посебна обрада података.

*Укупно 4.212 или $23,7 \%$ радника и ученика и студента дневих миграната који путују свакодневно до територије Београда (непозната општина) прелазе у просеку $27,7 \mathrm{~km}$.

Дневне миграције економски активног становништва такође се најинтензивније одвијају у радијусу од 20-30 километара, мада ова просторна зона обухвата мањи удео активних дневних миграната у поређењу са укупном масом дневне миграције у коју су укључени и ученици и студенти. Преовладава категорија кратких просторних 
раздаљина (до $30 \mathrm{~km}$ у једном смеру) за 90,6\% конвергентних и 92,3\% дивергентних дневних миграната. Издвајање зоне водећих долазака активног становништва показује да у конвергентним дневним миграцијама највише учествују становници насеља удаљених између 10 и 20 километара од Панчева, док је у случају дивергентних дневних миграција највише заступљена трећа просторна зона која обухвата Београд. Доминација функције рада и њима кореспондирајући токови дневних миграција одлика су дневних миграционих токова правца Београд - Панчево у којима преко $95 \%$ чини активно становништво. То указује да да разлике у степену развијености више утичу на учешће у дневним миграцијама од саобраћајне и просторне удаљености насеља. Из града свакодневно на посао у остала насеља Општине путује свега 216 радника.

Табела 42. Радијус кретања активних дневних миграната Града Панчева 2002. године

\begin{tabular}{|c|c|c|c|c|c|c|c|c|c|}
\hline \multicolumn{2}{|c|}{$\begin{array}{l}\text { Удаљеност од } \\
\text { Панчева (km) }\end{array}$} & До 10 & $10-19$ & $20-29$ & $30-39$ & $40-49$ & $50-59$ & $\begin{array}{l}60 \text { и } \\
\text { више }\end{array}$ & Укупно \\
\hline \multirow{2}{*}{$\begin{array}{c}\text { Конвергентни } \\
\text { дневни } \\
\text { мигранти }\end{array}$} & Epoj & 1.696 & 5.354 & 3.429 & 764 & 136 & 65 & 114 & 11.570 \\
\hline & $\%$ & 14,6 & 46,3 & 29,6 & 6,6 & 1,2 & 0,6 & 0,9 & 80,2 \\
\hline \multicolumn{2}{|c|}{ Epof нaceha } & 1 & 8 & 21 & 20 & 26 & 18 & 20 & 114 \\
\hline \multirow{2}{*}{$\begin{array}{l}\text { Дивергентни } \\
\text { дневни } \\
\text { мигранти }\end{array}$} & Бpoj & - & 176 & 2.457 & 89 & 14 & 7 & 66 & 2.853 \\
\hline & $\%$ & - & 6,2 & 86,1 & 3,1 & 0,5 & 0,2 & 2,3 & 19,8 \\
\hline \multicolumn{2}{|c|}{ Epoj Hacela } & $\cdot$ & 3 & 17 & 11 & 10 & 3 & 21 & 65 \\
\hline \multirow{2}{*}{ Укупно } & Epoj & 1.696 & 5.530 & 5.886 & 853 & 150 & 72 & 180 & 14.423 \\
\hline & $\%$ & 11,7 & 38,3 & 40,8 & 5,9 & 1,0 & 0,5 & 1,2 & 100,0 \\
\hline
\end{tabular}

Приликом проучавања дневних миграција у Војводини шездесетих година 20. века М. Бајић је анализирао проценте путујуће радне снаге са одређених удаљености до центра Панчева као једног од пет издвојених гравитационих подручја (Бајић, према CDI-IDN, 1971). У поређењу са овим подацима може се извести закључак о значајном порасту удела активних дневних миграната Панчева који долазе из треће просторне зоне у периоду 1961-2002. година.

Панчево се у односу на Београд налази у оквиру изохроне од 40 минута. Изохрона од четредест минута до једног сата најчешће се користи за одређивање метрополитенског подручја. (Berry, 1977, према Taaffe E., H.Gauthier, T.Maraffa, 1980). Има сазнања да мали градови у близини метропола имају значајну улогу у смањењу дневне миграције из неметрополитанских подручја у метрополе на удаљеностима између 25 и 35 миља (Taaffe E., H.Gauthier, T.Maraffa, 1980).

Уместо изохрона у нашем случају примењена је метода изотела за израду Карте 7. која представља геометријску изотелну карту Панчева и околине. Изотеле у виду концентричних кругова спајају места на једнаким просторним удаљеностима од 10, 20, 30 и $40 \mathrm{~km}$, а центар круга је град Панчево. Геометријске изотеле приказују оквирне зоне гравитације ка Панчеву. Површина прве изотелне зоне или круга износи $314 \mathrm{~km}^{2}$, друге $1.256 \mathrm{~km}^{2}$, треће $2.826 \mathrm{~km}^{2}$ и четврте $5.024 \mathrm{~km}^{2}$. Из ове четири гравитационе зоне града Панчева долази преко $90 \%$ дневних миграната. 


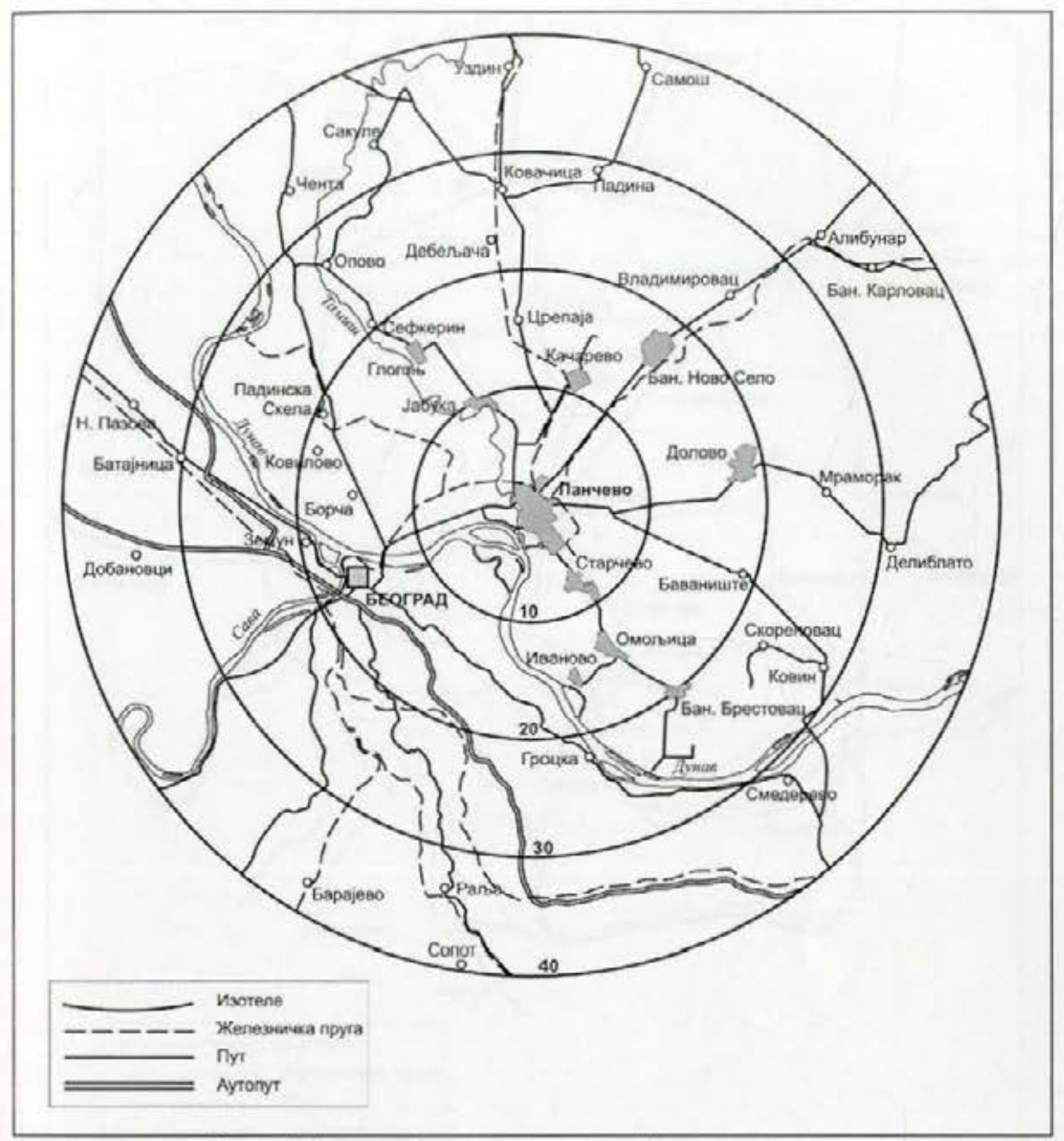

Карта 7. Геометријска изотелна карта Панчева и околине

Букуров Б., (1970) је одређујуһи гравитационе сфере војвођанских градова издвојио три мезоподручја у Банату: зрењанинско, панчевачко и вршачко. Граница панчевачког и вршачког гравитационог подручја протезала се у то време поред насеља Дубовац, тако да су Панчеву припадали Мраморак, Делиблато и Дубовац. Источна половина Јужног Баната припадала је гравитационом подручју Вршща, при чему је граница између ова два мезоподручја била на простору општине Алибунар. Насеља Локве и Јаношик гравитирала су ка Вршщу. Изузетно мали број дневних миграната из насеља Локве, Јаношик и Николинци у источном делу општине Алибунар, који гравитирају ка Панчеву 2002. године упућује да је у периоду 1961-2002. година није било знатнијих промена већ формираног панчевачког функщионалог подручја, нити његовог просторног ширења. Граница између функционалних подручја Панчева и Вршща остала је готово непромењена. На простору општине Ковин граница панчевачког и вршачког функционалног подручја простире се источно од насельа Дубовац не обухватајући га као што је то раније био случај. 


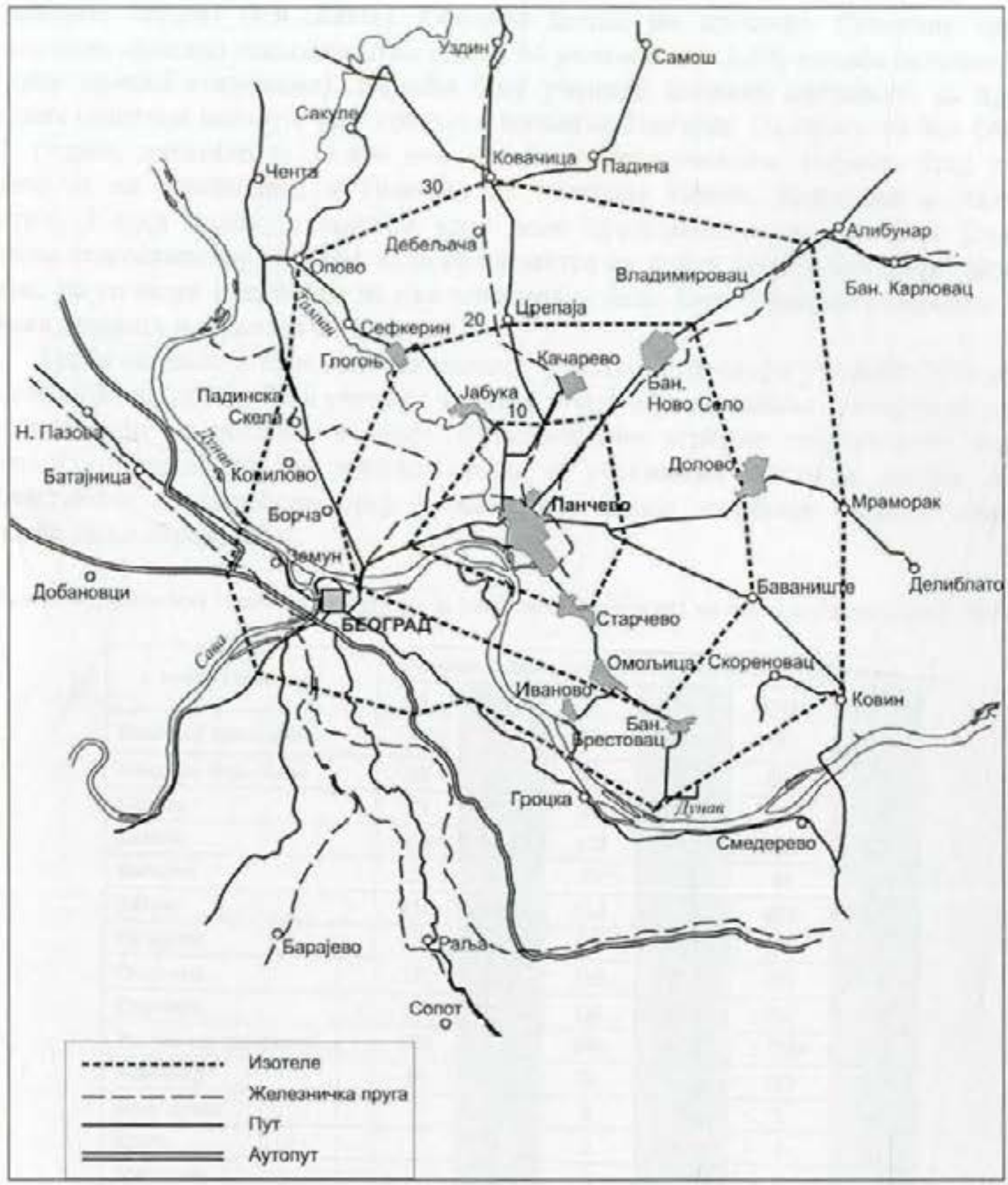

Карта 8. Реална изотелна карта Панчева и околине

На реалној изотелној карти Панчева и околине приказана је стварна удаљеност у километрима од града Панчева, путевима и железничким пругама. Одступања између геометријске и реалне изотелне карте Панчева и околине највећа су на југозападу због угицаја рељефа. На простору равничарског Баната ова одступања су знатно мања односно геометријске изотеле су много приближније реалним.

\section{Простор опитине Панчево као апсорпциони центар дневни миграната}

На простор општине Панчево свакодневно долази 14.619 дневних миграната, од чега 12.014 или 82,2\% радника (у даљем тексту РДМ) и 2.605 или $17,8 \%$ ученика (у даљем тексту УДМ). Највећи број радника (8.482) и ученика (1.721) учествује у локалним дневним миграцијама ка општинском центру. Са територије других општина до школе у Панчеву свакодневно путују 884 ученика од чега највише из суседних банатских општина Ковина и Ковачице.

Привлачност Панчева за ученике са простора других општина произилази из његове улоге у мрежи школских центара Србије (19 основних, 8 средњих, и 6 
специјалних школа) (Р3С,2003а). Основне школе на простору Општине привлаче првенствено локално становништво (свега 94 ученика или $3,6 \%$ похађа основну школу ван свог насеља становања). Највећи број ученика дневних миграната са простора суседних општина школује се у средњим школама Панчева. Са простора ван Општине 2002. године долазило је $33,8 \%$ дневних миграната ученика. Највећи број ученика долазио је на школовање у Панчево из општина Ковин, Ковачица и Алибунар. Општину Ковин одликује највећи удео деце предшколског и школског узраста у укупном становништву (17,3\%), када се посматра на нивоу Баната као шире просторне целине, па се може очекивати да ова општина и даље буде значајан емисиони центар ученика дневних миграната ка Панчеву.

Треба нагласити изражену несразмеру у полној структури ученика (30\% ученика женског пола на према $70 \%$ ученика мушког пола) која се запажа у токовима дневних миграција који за полазиште имају функционално аграрно оријентисану општину Опово. С обзиром да се већином ради о ученицима средњих школа можемо претпоставити да одређени број женске деце након завршене основне школе не наставља даље образовање.

Табела 43. Општина Панчево као центар конвергентних дневних миграција ученика 2002. године

\begin{tabular}{|l|c|c|c|c|c|c|}
\hline \multirow{2}{*}{ Место становања } & \multicolumn{5}{|c|}{ Ученици дневни мигранти који се школују у Панчеву } \\
\cline { 2 - 7 } & М & $\%$ & \% & $\%$ & Укупно & $\%$ \\
\hline Банатски Брестовац & 73 & 51,0 & 70 & 49,0 & 143 & 5,5 \\
\hline Банатско Ново Село & 96 & 51,1 & 92 & 48,9 & 188 & 7,2 \\
\hline Глогоњ & 71 & 50,7 & 69 & 49,3 & 140 & 5,4 \\
\hline Аолово & 112 & 50,7 & 109 & 49,3 & 221 & 8,5 \\
\hline Иваново & 18 & 38,3 & 29 & 61,7 & 47 & 1,8 \\
\hline Јабука & 110 & 49,3 & 113 & 50,7 & 223 & 8,6 \\
\hline Качарево & 104 & 46,2 & 121 & 53,8 & 225 & 8,7 \\
\hline Омольца & 121 & 52,4 & 110 & 47,6 & 231 & 8,9 \\
\hline Старчево & 164 & 54,7 & 136 & 45,3 & 300 & 11,6 \\
\hline Укупно унутрашњи улаз & 869 & 50,6 & 849 & 49,4 & $1.718 *$ & 66,2 \\
\hline Алибунар & 50 & 47,6 & 55 & 52,4 & 105 & 4,0 \\
\hline Бела Чрква & & & 1 & 100,0 & 1 & 0,0 \\
\hline Вршац & & & 2 & 100,0 & 2 & 0,1 \\
\hline Зрењанин & & & 2 & 100,0 & 2 & 0,1 \\
\hline Ковачица & 188 & 60,8 & 121 & 39,2 & 309 & 11,9 \\
\hline Ковин & 162 & 48,9 & 169 & 51,1 & 331 & 12,8 \\
\hline Опово & 15 & 30,0 & 35 & 70,0 & 50 & 1,9 \\
\hline Пландиште & & & 2 & 100,0 & 2 & 0,1 \\
\hline београдске општине & 42 & 56,7 & 32 & 43,2 & 74 & 2,9 \\
\hline Непознато & 4 & 80,0 & 1 & 20,0 & 5 & 0,3 \\
\hline Укупно сполашњи улаз & 461 & 52,3 & 420 & 47,7 & 881 & 34,1 \\
\hline Укупно & 1.330 & 51,0 & 1.269 & 49,0 & 2.605 & 100 \\
\hline
\end{tabular}

Извор података: Р3С,2007 Посебна обрада података.

Географски размештај насеља из којих ученици долазе на школовање у Панчево указује да ученици из насеља која се налазе у западном делу општина Алибунар (насеља Алибунар, Банатски Карловац и Владимировац) и Ковин (насеља Ковин, Баваниште, Скореновац, Мраморак) претежно гравитирају ка Панчеву, док ученици из

\footnotetext{
- Шест ученика дневних миграната школује се у другом насељу Општине које није општински центар.
} 
других насеља ових општина вероватно гравитирају ка Вршцу. Ученици са простора општине Опово већином не гравитирају ка Панчеву, већ вероватно ка Београду. Овакав однос функционалне привлачности постојао је и 60 -их година 20. века. ${ }^{17}$

У границама административног подручја општине Панчево одвијају се веома интензивне дневне миграције на релацији насеље становања - насеље рада. У локалним дневним миграцијама највише учествују радници из приградских насеља Старчева и Јабуке, која су најзначајнији центри полазишта локалних дневних миграната радника. Главни територијални правци дневних миграција усмерени су према општинском центру, док остала насеља примају мали број локалних дневних миграната, односно имају слабу функционалну привлачност која је резултат недовољно развијених функщија.

Табела 44. Конвергентна и днвергентна дневна кретања активног становништва у оквиру отштине Панчево 2002. године

\begin{tabular}{|c|c|c|c|c|c|c|c|c|c|c|c|}
\hline \multirow{2}{*}{$\begin{array}{c}\text { Конвергентна } \\
\text { кретања }\end{array}$} & \multicolumn{11}{|c|}{ Аивергентна кретана } \\
\hline & 5. 5 & 5.H.C & A & $\Gamma$ & n & 3 & $\mathrm{~K}$ & 0 & $\Pi$ & C & Укупно \\
\hline Б. Брестовац & - & & & & 1 & & & 15 & 11 & 5 & 32 \\
\hline 6. Hoso Ceno & & - & & & & & & & 28 & & 28 \\
\hline Долово & 1 & 1 & $\cdot$ & & & & & & 21 & 1 & 24 \\
\hline Глогон & & & & - & & 5 & & & 6 & & 11 \\
\hline Иваново & & & & & $\cdot$ & & & 11 & 6 & 1 & 18 \\
\hline Јабука & & 1 & 1 & 4 & & - & 20 & 1 & 45 & & 72 \\
\hline Качарево & & & 1 & & & 2 & - & & 33 & 1 & 37 \\
\hline Омољица & 11 & & & & 4 & & & - & 25 & 10 & 50 \\
\hline Панчево & 496 & 748 & 905 & 419 & 164 & 1.404 & 1.108 & 1.197 & $\cdot$ & 1.696 & 8.137 \\
\hline Старчево & 9 & & & & 1 & 2 & 1 & 19 & 41 & - & 73 \\
\hline Укупно & 517 & 750 & 907 & 423 & 170 & 1.413 & 1.129 & 1.243 & 216 & 1.714 & 8.482 \\
\hline
\end{tabular}

Извор података: Р3С, 2007 Посебна обрада података.

Најзначајнији центар запослења је град Панчево, ка коме се у највећем обиму крећу токови како локалних дневних миграција активног становништва тако и токови дневних миграција активног становништва са простора других општина.

Табела 45. Конвергентни активни дневни мигранти општине Панчево према насељу рада 2002.године

\begin{tabular}{|c|c|c|c|c|c|}
\hline \multirow[t]{2}{*}{ Место рада } & \multirow{2}{*}{$\begin{array}{c}\text { Укупно } \\
\text { конвергентни } \\
\text { РДМ }\end{array}$} & \multicolumn{2}{|c|}{$\begin{array}{c}\text { Унутрашњи } \\
\text { конвергентни РДМ }\end{array}$} & \multicolumn{2}{|c|}{$\begin{array}{c}\text { Cполашыьи } \\
\text { конвергентни } \\
\text { РДМ } \\
\end{array}$} \\
\hline & & $6 \mathrm{poj}$ & $\%$ & 6poj & $\%$ \\
\hline Б. Брестовац & 38 & 32 & 84,2 & 6 & 15,8 \\
\hline Б. Ново Село & 43 & 28 & 65,1 & 15 & 34,9 \\
\hline Долово & 39 & 24 & 61,5 & 15 & 38,5 \\
\hline Tnorotb & 28 & 11 & 39,3 & 17 & 60,7 \\
\hline Иваново & 18 & 18 & 100 & $\cdot$ & 0 \\
\hline Јабука & 82 & 72 & 87,8 & 10 & 12,2 \\
\hline Качарево & 52 & 37 & 71,2 & 15 & 28,8 \\
\hline Омољича & 58 & 50 & 86,2 & 8 & 13,8 \\
\hline Панчево & 11.571 & 8.137 & 70,3 & 3.434 & 29,7 \\
\hline Старчево & 86 & 73 & 84,9 & 13 & 15,1 \\
\hline Укупно & 12.015 & 8.482 & 70,6 & 3.533 & 29,4 \\
\hline
\end{tabular}

Извор података: Р3С,2007 Посебна обрада података.

\footnotetext{
${ }^{17}$ Види Илић Ј.,1967.
} 
После општинског центра нешто значајнији локални центар запослења је Старчево, док у осталим насељима доминира функција становања. У структури конвергентних активних дневних миграната општине Панчево $70,6 \%$ чине локални дневни мигранти, док $29,4 \%$ чине спољашњи дневни мигранти. Већина насеља прима до једне трећине радника који долазе са простора других општина. Више од једне трећине радника, који долазе из насеља ван граница Општине, у структури конвергентних токова активног становништва, имају насеља Глогоњ, Долово и Банатско Ново Село. Специфично је насеље Глогоњ, које је једино панчевачко насеље привлачније за раднике ван простора своје Општине него за локалну радну снагу. Само насеље Иваново није привлачно за раднике ван граница панчевачке општине.

Када је реч о спољашњим активним дневним мигрантима, до места рада на простору општине Панчево свакодневно путују већином радници који станују на подручју неке од београдских општина. Они у највећем броју раде у граду Панчеву, а затим у Старчеву. Половину дневних миграната града Панчева који путују из Београда чине радници са местом становања у општинама Палилула, Нови Београд и Звездара.

Табела 46. Конвергентни активни дневни мигранти општине Панчево према општини становања 2002. г.

\begin{tabular}{|c|c|c|c|c|c|c|c|c|c|c|c|c|c|}
\hline \multirow{3}{*}{$\begin{array}{l}\text { Место } \\
\text { рада }\end{array}$} & \multirow{3}{*}{$\begin{array}{c}\text { Укупно } \\
\text { спољашюи } \\
\text { конвергентни } \\
\text { РДМ }\end{array}$} & \multicolumn{12}{|c|}{ Општина становања } \\
\hline & & \multicolumn{2}{|c|}{ Беorpan } & \multicolumn{2}{|c|}{ Алибунар } & \multicolumn{2}{|c|}{ Ковачица } & \multicolumn{2}{|c|}{ Ковин } & \multicolumn{2}{|c|}{ Onoвo } & \multicolumn{2}{|c|}{ Octano } \\
\hline & & $6 p o j$ & $\%$ & $6 \mathrm{poj}$ & $\%$ & $6 p o j$ & $\%$ & $6 \mathrm{poj}$ & $\%$ & 6poj & $\%$ & $6 p o j$ & $\%$ \\
\hline Б. Брестовац & 6 & 1 & 16,7 & & & & & 5 & & & & & \\
\hline 5. Hoвo Ceno & 15 & 2 & 13,3 & 12 & 80,0 & 1 & 6,7 & & & & & & \\
\hline Aоnoso & 15 & 1 & 6,7 & & & & & 14 & 93,3 & & & & \\
\hline Fnorots & 17 & 2 & 11,8 & & & & & & & 14 & 82,3 & 1 & 5,9 \\
\hline Иваново & - & & & & & & & & & & & & \\
\hline Јабука & 10 & 1 & 10 & & & 6 & 60 & & & 2 & 20 & 1 & 10 \\
\hline Качарево & 15 & 6 & 40,0 & & & 6 & & & & 1 & & 2 & 13,3 \\
\hline Омољича & 8 & 3 & 37,5 & & & 1 & 12,5 & 2 & 25,0 & & & 2 & 25,0 \\
\hline Панчево & 3.434 & 1.488 & 43,3 & 296 & 8,6 & 411 & 11,9 & 881 & 25,6 & 194 & 5,6 & 164 & 4,8 \\
\hline Старчево & 13 & 9 & 69,2 & 2 & 15,4 & 1 & 7,7 & 1 & 7,7 & & & & \\
\hline Укупно & 3.533 & 1.514 & 42,8 & 310 & 8,8 & 426 & 12,1 & 902 & 25,5 & 211 & 5,9 & 170 & 4,8 \\
\hline
\end{tabular}

Извор података: Р3С,2007 Посебна обрада података.

У структури конвергентних токова активних дневних миграција, анализираних на нивоу појединачних насеља "примаоца" дневних миграната, запажа се да у Банатско Ново Село ради обављања функције рада долазе претежно радници из општине Алибунар, у Долово већином радници из општине Ковин, а у Глогоњ претежно радници из општине Опово. Оваквој структури дневних миграционих токова доприноси геосаобраћајни положај ових панчевачких насеља у односу на поменуте општине.

Укупна размена радне снаге Панчева са другим општинама је у односу $2: 1$, а првенствено у корист Београда. У укупној маси дневних миграционих токова са простора општина Ковин и Ковачица, токови према општини Панчево чине $43,3 \%$ и $39,5 \%$, односно $25 \%$ за општину Алибунар. У обиму дневне миграције активног становништва општине Панчево, у свакодневном кретању ка простору Општине учествује 4.417 радника из других општина, а из Панчева 8.539 радника путује на посао у друге општине. Поред локалних дневних миграција радне снаге на простору Општине, које су и најизраженије, у конвергентним дневним токовима активног становништва учествује и 1.514 радника из Београда који чине $42,8 \%$ од укупне структуре конвергентних дневних миграционих токова активног становништва са простора других општина на територију општине Панчево. По уделу у конвергентним токовима дневних миграција следе општине Ковин и Ковачица које простору општине 
Панчево свакодневно дају $25,5 \%$ односно $12,1 \%$ од укупног обима дневних токова активног становништва.

\section{Простор отитине Панчево као дисперзивни чентар дневних миграната}

Са простора општине Панчево свакодневно путује 8.484 дневних миграната, од qега 4.341 или $51,2 \%$ радника (скраћено РДМ) и 4.143 или $48,8 \%$ ученика (скраћено УдМ). Највећи број ученика и студената који путују на школовање ван простора општине има општински центар - град Панчево, а затим насеље Качарево које даје више од $5 \%$ од укупног обима дивергентних дневних миграција ученика и студената Панчева. У структури дивергентних дневних миграција ученика/студената према полу преовладава женска популација.

Табела 47. Општина Панчево као центар дивергентних дневних миграција ученика/студената 2002.год.

\begin{tabular}{|l|c|c|c|c|c|c|}
\hline Место станована & M & $\%$ & Ж & $\%$ & Укупно & $\%$ \\
\hline Банатски Брестовац & 18 & 36,7 & 31 & 63,3 & 49 & 1,2 \\
\hline Банатско Ново Село & 43 & 31,6 & 93 & 68,4 & 136 & 3,3 \\
\hline Глогон & 28 & 50,9 & 27 & 49,1 & 55 & 1,3 \\
\hline Долово & 34 & 39,5 & 52 & 60,5 & 86 & 2,1 \\
\hline Иваново & 2 & 50,0 & 2 & 50,0 & 4 & 0,1 \\
\hline Јабука & 37 & 32,7 & 76 & 67,3 & 113 & 2,8 \\
\hline Качарево & 77 & 34,8 & 144 & 65,2 & 221 & 5,4 \\
\hline Омолица & 39 & 35,5 & 71 & 64,5 & 110 & 2,7 \\
\hline Панчево & 1.273 & 40,4 & 1.877 & 59,6 & 3.150 & 77,2 \\
\hline Старчево & 65 & 41,4 & 92 & 58,6 & 157 & 3,8 \\
\hline Непознато & 23 & 37,1 & 39 & 62,9 & 62 & 1,5 \\
\hline Укупно општина & 1.639 & 39,6 & 2.504 & 60,4 & 4.143 & 100 \\
\hline
\end{tabular}

Извор података: Р3С,2007 Посебна обрада података.

У односу на суседне општине, у токове дневних миграција у Панчеву више су укључени ученици и студенти. Од укупног обима дивергентне дневне миграције ученика и студената Панчева највише чине дневне миграције студената $(80,8 \%)$. На то утиче близина Београда као највећег универзитетског и културног центра у земљи, у који путује 3.764 ученика и студената општине Панчево, или $64,1 \%$ од укупног броја дневних миграната ученика и студената са простора Општине. Средњу школу похађа $13,7 \%$ ученика дневних миграната, док је ученика основних школа свега $0,6 \%$. Чак $90,8 \%$ ученика/студената дивергентних дневних миграната школује се у Београду, чему доприноси велики број студената који свакодневно путују са простора Општине. После београдских средњих школа, ученици већином путују до средњих школа на простору општина Алибунар и Ковачица. Средњошколци из Банатског Hoвоr Села чине већину у дневним миграционим токовима ученика између општина Панчево и Алибунар, док до средњих школа у општини Ковачица путују у највећем броју ученици из града Панчева и Качарева. 
Табела 48. Дивергентне дневне миграције ученика/студента општине Панчево, према општини школовања 2002, године

\begin{tabular}{|c|c|c|c|c|c|c|c|}
\hline \multirow[b]{2}{*}{ Општина школовања } & \multicolumn{7}{|c|}{ Школа коју лице похађа } \\
\hline & Ооновна & $\%$ & Cредіta & $\%$ & $\begin{array}{l}\text { Виша и } \\
\text { висока }\end{array}$ & $\%$ & Укугпно \\
\hline Алибунар & 1 & 3,7 & 49 & 8,7 & 0 & 0 & 50 \\
\hline Вршац & 0 & 0,0 & 2 & 0,4 & 24 & 0,7 & 26 \\
\hline Зренанин & 0 & 0,0 & 0 & 0,0 & 14 & 0,4 & 14 \\
\hline Ковачица & 2 & 7,4 & 47 & 8,3 & 0 & 0,0 & 49 \\
\hline Вождовац & 0 & 0,0 & 13 & 2,3 & 51 & 1,4 & 64 \\
\hline Врачар & 2 & 7,4 & 21 & 3,7 & 50 & 1,4 & 73 \\
\hline Звездара & 0 & 0,0 & 28 & 4,9 & 106 & 3,0 & 134 \\
\hline Земун & 2 & 7,4 & 17 & 3,0 & 162 & 4,6 & 181 \\
\hline Нови Београд & 2 & 7,4 & 8 & 1,4 & 20 & 0,6 & 30 \\
\hline Палилула & 0 & 0,0 & 19 & 3,4 & 74 & 2,1 & 93 \\
\hline Савски Венац & 0 & 0,0 & 17 & 3,0 & 47 & 1,3 & 64 \\
\hline Стари Град & 0 & 0,0 & 0 & 0,0 & 5 & 0,1 & 5 \\
\hline Чукарица & 0 & 0,0 & 2 & 0,4 & 16 & 0,5 & 18 \\
\hline београдске општине-непознато & 8 & 29,6 & 304 & 53,7 & 2.790 & 78,6 & 3.102 \\
\hline 6еоградске општине укупно & 14 & 51,9 & 429 & 75,8 & 3.321 & 93,5 & 3.764 \\
\hline Oстале општине & 0 & 0,0 & 23 & 4,1 & 155 & 4,4 & 178 \\
\hline Непознато & 10 & 37,0 & 16 & 2,8 & 36 & 1,0 & 62 \\
\hline Укупно Општина & 27 & 100 & 566 & 100 & 3.550 & 100 & 4.143 \\
\hline
\end{tabular}

Извор података: Р3С, 2007 Посебна обрада података.

У структури дивергентних активних дневних миграната општине Панчево $66,1 \%$ чине локални дневни мигранти, док $33,8 \%$ чине спољашњи дневни мигранти. Најобимнији токови дневних миграција активног становништва ка другим општинама крећу се из града Панчева. После општинског центра, по обиму спољашњих дневних миграција активног становништва истичу се насеља Качарево и Глогоњ. Радници из ових насеља већином раде у Београду.

Табела 49. Дивергентни активни дневни мигранти општине Панчево према насељу становања 2002. г.

\begin{tabular}{|c|c|c|c|c|c|}
\hline \multirow[t]{2}{*}{$\begin{array}{c}\text { Место } \\
\text { станована }\end{array}$} & \multirow{2}{*}{$\begin{array}{c}\text { Укупно } \\
\text { дивергентни } \\
\text { РДМ }\end{array}$} & \multicolumn{2}{|c|}{$\begin{array}{c}\text { Унутрашини } \\
\text { дивергентни } \\
\text { РАМ* }\end{array}$} & \multicolumn{2}{|c|}{$\begin{array}{c}\text { Cполашын } \\
\text { дивергентни } \\
\text { РАМ* }\end{array}$} \\
\hline & & 6poj & $\%$ & $6 p o j$ & $\%$ \\
\hline 5. Брестовац & 576 & 517 & 89,8 & 59 & 10,2 \\
\hline Б. Ново Село & 939 & 750 & 79,9 & 189 & 20,1 \\
\hline Долово & 1039 & 907 & 87,3 & 132 & 12,7 \\
\hline Гnorols & 606 & 423 & 69,8 & 183 & 30,2 \\
\hline Иваново & 177 & 170 & 96,0 & 7 & 4,0 \\
\hline Јабука & 1.552 & 1.413 & 91,0 & 139 & 9,0 \\
\hline Качарево & 1.623 & 1.129 & 69,6 & 494 & 30,4 \\
\hline Омољица & 1.338 & 1.243 & 92,9 & 95 & 7,1 \\
\hline Панчево & 3.069 & 216 & 7,0 & 2.853 & 93,0 \\
\hline Crapueso & 1.904 & 1.714 & 90,0 & 190 & 10,0 \\
\hline Укупно & 12.823 & 8.482 & 66,1 & 4.341 & 33,8 \\
\hline
\end{tabular}

Извор података: Р3С, 2007 Посебна обрада података. 
Економски активни дневни мигранти општине Панчево путују на посао већином у неку од београдских општина (3.883 или $89,4 \%$ ). По броју дневних миграната радника које свакодневно примају са простора општине Панчево предњаче Палилула, Савски Венац и Стари Град.

Табела 50. Дивергентни активни дневни мигранти општине Панчево према општини рада 2002 год.

\begin{tabular}{|c|c|c|c|c|c|c|c|c|c|c|c|c|c|c|c|}
\hline \multirow{3}{*}{$\begin{array}{c}\text { Место } \\
\text { становања }\end{array}$} & \multirow{3}{*}{$\begin{array}{c}\text { Укупно } \\
\text { сполашни } \\
\text { Аивергентни } \\
\text { РДМ }\end{array}$} & \multicolumn{14}{|c|}{ Место рада } \\
\hline & & \multicolumn{2}{|c|}{ Бeограa } & \multicolumn{2}{|c|}{ Алибунар } & \multicolumn{2}{|c|}{ Ковачица } & \multicolumn{2}{|c|}{ Ковин } & \multicolumn{2}{|c|}{ Onoso } & \multicolumn{2}{|c|}{ Остало } & \multicolumn{2}{|c|}{ Непознато } \\
\hline & & $6 p o j$ & $\%$ & $6 p o j$ & $\%$ & 6poj & $\%$ & $6 p o j$ & $\%$ & 6poj & $\%$ & $6 p o j$ & $\%$ & 6poj & $\%$ \\
\hline 5. Брестовац & 59 & 49 & 83,1 & & & & & 4 & 6,8 & & & 2 & 3.4 & 4 & 6,8 \\
\hline 5. Hoeo Ceno & 189 & 170 & 89,9 & & & & & & & & & & & 19 & 10,1 \\
\hline Aonoeo & 132 & 105 & 79,5 & & & 3 & 2,3 & 10 & 7,6 & & & & & 14 & 10,6 \\
\hline Fnorolb & 183 & 168 & 91,8 & & & 1 & 0,5 & & & 8 & 4,4 & 1 & 0,5 & 5 & 2,7 \\
\hline Иеаново & 7 & 5 & 71,4 & & & & & & & & & 1 & 14,3 & 1 & 14,3 \\
\hline Ja6yкa & 139 & 114 & 82,0 & & & 3 & 2,2 & 1 & 0,7 & 5 & 3,6 & 1 & 0,7 & 15 & 10,8 \\
\hline Качарево & 494 & 464 & 93,9 & & & 14 & 2,8 & & & & & 4 & 0,8 & 12 & 2,4 \\
\hline Омољица & 95 & 75 & 78,9 & & & 1 & 1,1 & & & & & 3 & 3,2 & 16 & 16,8 \\
\hline Панчево & 2.853 & 2.583 & 90,5 & 46 & 1,6 & 46 & 1,6 & 53 & 1,9 & 15 & 0,5 & 68 & 2,4 & 42 & 1,5 \\
\hline Crapueso & 190 & 150 & 78,9 & 1 & 0,5 & 1 & 0,5 & 6 & 3,2 & & & 3 & 1,6 & 29 & 15,3 \\
\hline Yкупно & 4.341 & 3.883 & 89,4 & 47 & 1,1 & 69 & 1,6 & 74 & 1,7 & 28 & 0,6 & 83 & 1,9 & 157 & 3,6 \\
\hline
\end{tabular}

Извор података: Р3С,2007 Посебна обрада података.

Од других општина, осим београдских, које свакодневно примају радну снагу са простора општине Панчево, нешто значајнији су само токови радне снаге ка општини Ковин, односно њеном општинском средишту. У Ковин већином путују радници из града Панчева и Долова. Највећи број радника непознате општине рада полази из Омољице.

\section{2. Структурна обележја популације дневних миграната}

Структурна обележја дневних миграната (активног становништва и школске и студентске омладине) општине Панчево разматрана су са циљем тестирања међузависности структурних обележја популације дневних миграната и обима и територијалних праваца дневне миграције, односно утврђивања услова у којима преовладава тенденција ка конвергенцији или дивергенцији. Анализирана је селективност дневних миграната према значајнијим биолошким и социо-економским обележјима (полна и старосна структура за ученике/студенте, и структура активних дневних миграната према полу, старости, брачном стању, образовању, сектору делатности рада, миграционим карактеристикама, стамбеном статусу, поседовању пољопривредног газдинства), као и одређена демографска и економска обележја породица активних дневних миграната који живе/раде на простору општине Панчево. Проучавање мање уопштених података, на нивоу појединачних дневних миграната, пружило је широке могућности анализе с обзиром на значајне варијације које постоје између појединаца.

\section{Старосно-полна структура}

Полну структуру дневних миграната општине Панчево карактерише веће учешће мушког $(59,8 \%)$ у односу на женско становништво $(40,2 \%)$. Томе доприноси велики број радника мушког пола (10.844 или $66,3 \%$ од мушке популације дневних миграната) који учествује у дневним миграцијама. Ученици/студенти мушког пола (њих 2.973) чине $34 \%$ мушке популације дневних миграната. Разлике у полној 
структури становништва приметније су када је реч о конвергентним дневним мигрантима у односу на дивергентне. Од жена дневних миграната 5.511 или $33,7 \%$ чине раднице и 3.775 или $55,9 \%$ ученице/студентице. Простор Општине више прима дневне мигранте мушког пола, док са простора Општине готово подједнако путује становништво оба пола. Малим разликама у полној структури дивергентних дневних миграната доприноси знатан број ученика и студената женског пола који путују на школовање ван простора Општине, као и нешто већи удео жена у структури активних дивергентних у односу на активне конвергентне дневне мигранте.

У дневним миграцијама ка/из Панчева учествују активни мушкарци и жене у односу 2:1. Жене из Банатског Новог Села и Глогоња најмање учествују у дневним миграцијама, док више од $50 \%$ женске радне снаге примају Банатски Брестовац, Банатско Ново Село, Долово и Старчево. Само град Панчево више даје женску радну снагу него што је прима а то се, с обзиром на обим дневне миграције овог насеља, одражава на полну структуру конвергентних и дивергентних активних дневних миграната на нивоу целе Општине. У град Панчево свакодневно долази мушка радна снага чак за $10 \%$ више него што одлази. Однос мушке и женске радне снаге коју Град прима са простора матичне општине и других општина прилично је равномеран и износи $68 \%$ на према $32 \%$.

Табела 51. Полна структура активних дневних миграната општине Панчево (\%) 2002. године

\begin{tabular}{|l|c|c|c|c|c|c|}
\hline \multirow{2}{*}{ Насеље } & \multicolumn{2}{|c|}{$\begin{array}{c}\text { Укупно } \\
\text { Аневни } \\
\text { мигранти }\end{array}$} & \multicolumn{2}{c|}{$\begin{array}{c}\text { Конвергентни } \\
\text { Аневни мигранти }\end{array}$} & \multicolumn{2}{c|}{$\begin{array}{c}\text { Дивергентни } \\
\text { Аневни мигранти }\end{array}$} \\
\cline { 2 - 7 } & Мушкарци & Жене & Мушкарци & Жене & Мушкарци & Жене \\
\hline Б. Брестовац & 59,8 & 40,2 & 42,1 & 57,9 & 71,2 & 28,8 \\
\hline Б. Н. Село & 70,3 & 29,7 & 44,2 & 55,8 & 76,2 & 23,8 \\
\hline Долоео & 69,6 & 30,4 & 48,7 & 51,3 & 75,8 & 24,2 \\
\hline Глогон & 76,3 & 23,7 & 50,0 & 50,0 & 80,3 & 19,7 \\
\hline Иваново & 64,0 & 36,0 & 61,1 & 38,9 & 71,4 & 28,6 \\
\hline Јабука & 66,5 & 33,5 & 52,4 & 47,6 & 74,8 & 25,2 \\
\hline Качарево & 67,4 & 32,6 & 61,5 & 38,5 & 68,0 & 32,0 \\
\hline Омолица & 59,5 & 40,5 & 50,0 & 50,0 & 65,3 & 34,7 \\
\hline Панчево & 66,3 & 33,7 & 68,1 & 31,9 & 58,9 & 41,1 \\
\hline Старчево & 58,3 & 41,7 & 44,2 & 55,8 & 64,7 & 35,3 \\
\hline Укупно & 66,3 & 33,7 & 67,4 & 32,6 & 63,2 & 36,8 \\
\hline
\end{tabular}

Извор података: Р3С,2007 Посебна обрала података.

Може се закључити да веће учешће мушкараца у дневним миграцијама активног становништва Панчева потврђује досадашња сазнања о овом облику просторне покретљивости становништва, односно чињеницу да жене мање учествују у дневним миграцијама од мушкараца. У односу на просек Србије, где мушкарци учествују са $65 \%$, а жене са $35 \%$ у дневним миграцијама, дневне миграције радника ка Панчеву одликује нешто већи удео мушке радне снаге, што је у складу са индустријским карактером привреде општине Панчево. Жене више учествују у дневним миграцијама у оквиру граница Општине. Град Панчево је највећи дисперзивни центар активних жена.

Простор Општине добија мушку радну снагу са простора суседних општина више него што њено активно мушко становништво одлази да ради у ове општине. Насупрот томе, из општине Панчево женска радна снага у већој мери одлази да ради на простор суседних општина више него што из њих долази. Једино када је реч о београдским општинама размена и мушке и женске радне снаге је прилично равномерна. 


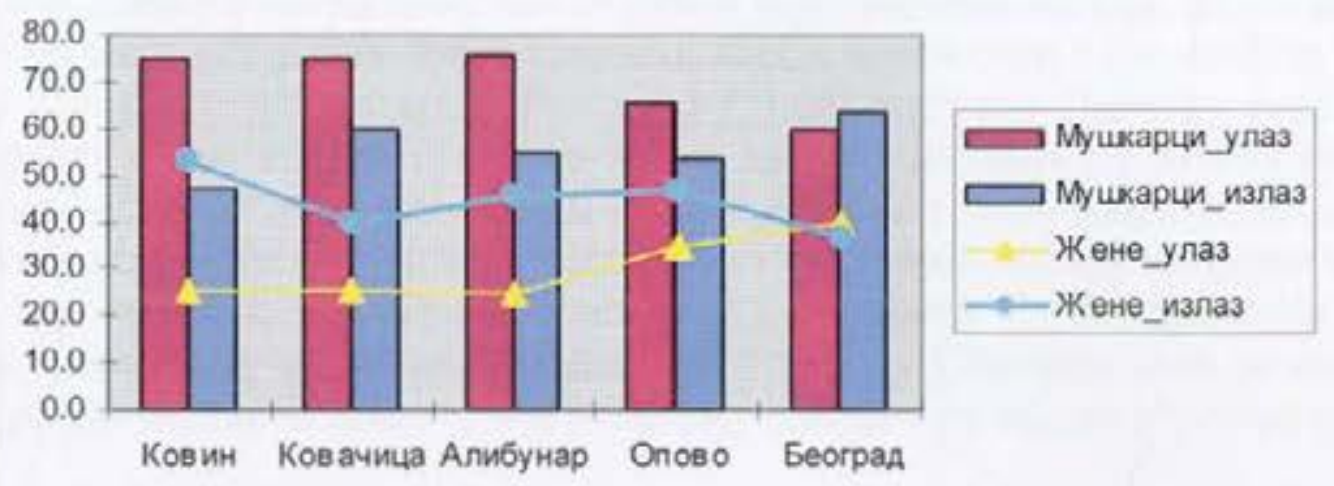

Извор података: Р3С,2007 Посебна обрада података.

У структури токова у оба смера највеһе учешһе у дневној миграцији имају радници у старосној групи 45-50 година. То је у складу са сазнањима других аутора о вероватноһи за учешће у дневној митрацији радника одређених старосних група (Lee B.S., J.Mc Donald, 2003; Romani J., J.Surin, M.Artis,2003). Веома мали број активних дневних миграната општине Панчево је млађи од деветнаест и старији од шездесет година, док је више од половине старости између четрдесет и педесет девет година. Овој старосној групи припада $56,1 \%$ од укупног броја мушкараца и $53,8 \%$ од укупног броја жена дневних миграната Панчева. Ако се посматра на нивоу појединачних насеља највећи удео младих у структури активних дневних миграната има Старчево, док је удео радника старијих од шездесет година највеһи у Глогоњу. Истичу се Старчево и Омољица као насеља која већином примају/дају радну снагу млађе средовечне старосне групе, насупрот Иванову и граду Панчеву који већином примају/дају раднике старије ередовечне старосне групе.

Табела 52. Старосна структура активних дневних миграната општине Панчево (\%) 2002. године॰

\begin{tabular}{|c|c|c|c|c|c|c|c|c|c|c|c|c|}
\hline \multirow{3}{*}{ Hacere } & \multicolumn{12}{|c|}{ Старосна група } \\
\hline & \multicolumn{3}{|c|}{$15-19$} & \multicolumn{3}{|c|}{$20-39$} & \multicolumn{3}{|c|}{$40-59$} & \multicolumn{3}{|c|}{$60+$} \\
\hline & $M$ & Ж & Укупно & $M$ & 世 & Укупно & M & K & Укупно & M & * & Укупно \\
\hline Б. Брестовац & 0,0 & 0,0 & 0,0 & 46,6 & 56,4 & 50,5 & 51,7 & 41,0 & 47,4 & 1,7 & 0,0 & 1,0 \\
\hline Б. Hoso Ceno & 1,8 & 0,0 & 1,3 & 42,3 & 58,0 & 47,0 & 54,0 & 42,0 & 50,4 & 1,8 & 0,0 & 1,3 \\
\hline Alnoso & 0,8 & 0,0 & 0,6 & 45,4 & 61,5 & 50,3 & 51,3 & 36,5 & 46,8 & 1,7 & 1,9 & 1,8 \\
\hline Tnorots & 0,6 & 2,0 & 0,9 & 44,1 & 46,0 & 44,5 & 52,2 & 52,0 & 52,1 & 3,1 & 0,0 & 2,4 \\
\hline Иваново & 0,0 & 0,0 & 0,0 & 31,3 & 55,6 & 40,0 & 68,8 & 44,4 & 60,0 & 0,0 & 0,0 & 0,0 \\
\hline Ja6yka & 0,0 & 0,0 & 0,0 & 48,3 & 54,1 & 50,2 & 51,0 & 44,6 & 48,9 & 0,7 & 1,4 & 0,9 \\
\hline Качарево & 0,8 & 0,6 & 0,7 & 41,8 & 57,9 & 47,1 & 56,8 & 41,6 & 51,8 & 0,5 & 0,0 & 0,4 \\
\hline Oмольича & 1,1 & 0,0 & 0,7 & 50,5 & 53,2 & 51,6 & 46,2 & 43,5 & 45,1 & 0,0 & 1,6 & 0,7 \\
\hline Панчево & 0,4 & 0,9 & 0,6 & 41,7 & 43,1 & 42,2 & 56,6 & 55,3 & 56,2 & 1,0 & 0,2 & 0,7 \\
\hline Crapueso & 1,9 & 2,6 & 2,2 & 51,6 & 53,0 & 52,2 & 44,1 & 43,5 & 43,8 & 1,2 & 0,0 & 0,7 \\
\hline Хкупно & 0,5 & 0,9 & 0,6 & 42,1 & 44,5 & 42,9 & 56,1 & 53,8 & 55,3 & 1,0 & 0,2 & 0,7 \\
\hline
\end{tabular}

Проценат од укупног броја активних дневних миграната мушкараца, проценат од укупног броја активних дневних миграната жена, и проценат од укупног броја активних дневних миграната.

Извор података: Р3С.2007 Посебна обрада података.

Кала је реч о размени радне снаге са другим општинама специфично је да, са изузетком Београда, на простор суседних општина свакодневно путује на посао веһи удео становништва старијег од 60 година, него што из истих општина долази у Панчево. Ова лица веһином раде у примарном сектору делатности. 
Нема великих разлика у просечној старости активних дневних миграната између различитих токова дневних миграција општине Панчево (конвергентних и дивергентних дневних миграната), или на нивоу појединачних насеља, због специфичне структуре дневних миграната према старости која је знатно мање сложена од старосне структуре укупног становништва. Дневни мигранти општине Панчево у просеку су стари тридесет и три године и конвергентни дневни мигранти су нешто старији од дивергентних. Највећу просечну старост имају дневни мигранти Иванова. Када је реч о конвергентним дневним мигрантима, просечно су најстарији дневни мигранти који раде у Долову, док просечно најмлађи радници раде у Омољици. Од дивергентних дневних миграната просечно су најмлађи радници који станују у Старчеву. Ако се има у виду полна структура активних дневних миграната мушкарци су у просеку старији од жена.

Табела 53. Просечна старост активних дневних миграната општине Панчево 2002. године

\begin{tabular}{|l|c|c|c|c|c|c|c|c|c|}
\hline \multirow{2}{*}{ Насеље } & \multicolumn{3}{|c|}{$\begin{array}{c}\text { Просечна старост } \\
\text { конвергентних дневних } \\
\text { миграната }\end{array}$} & \multicolumn{2}{c|}{$\begin{array}{c}\text { Просечна старост } \\
\text { дивергентних } \\
\text { дневних миграната }\end{array}$} & \multicolumn{3}{|c|}{$\begin{array}{c}\text { Просечна старост } \\
\text { дневих миграната } \\
\text { Укупно }\end{array}$} \\
\cline { 2 - 11 } & М & Ж & Укупно & М & Ж & Укупно & M & Ж & Укупно \\
\hline Б. Брестовац & 31,2 & 30,3 & 32,0 & 32,5 & 31,6 & 32,2 & 33,0 & 30,9 & 32,2 \\
\hline Б. Ново Село & 34,4 & 32,5 & 31,9 & 33,3 & 31,3 & 32,8 & 33,1 & 31,7 & 32,7 \\
\hline Долово & 33,8 & 33,0 & 33,4 & 32,4 & 30,6 & 32,0 & 32,6 & 31,5 & 32,3 \\
\hline Глогоњ & 32,5 & 32,5 & 32,5 & 33,4 & 32,5 & 33,2 & 33,3 & 32,5 & 33,1 \\
\hline Иваново & 33,9 & 31,8 & 33,1 & 35,5 & 32,5 & 34,6 & 34,4 & 31,9 & 33,5 \\
\hline Јабука & 33,8 & 32,9 & 33,4 & 32,3 & 31,5 & 32,1 & 32,7 & 32,2 & 32,6 \\
\hline Качарево & 31,3 & 35,0 & 32,7 & 33,4 & 31,2 & 32,7 & 33,2 & 31,6 & 32,7 \\
\hline Омольица & 29,7 & 32,0 & 30,8 & 32,2 & 31,5 & 32,0 & 31,4 & 31,7 & 31,5 \\
\hline Панчево & 33,3 & 33,1 & 33,2 & 32,9 & 32,1 & 32,6 & 33,2 & 32,8 & 33,1 \\
\hline Старчево & 33,0 & 30,7 & 31,7 & 31,2 & 31,8 & 31,4 & 31,6 & 31,3 & 31,5 \\
\hline укупно & 33,3 & 33,0 & 33,2 & 32,9 & 31,9 & 32,5 & 33,2 & 32,7 & 33,0 \\
\hline
\end{tabular}

Извор података: Р3С,2007 Посебна обрада података.

Разлике у просечној старости активних дневних миграната који свакодневно путују на релацији простор Општине - суседне општине и обрнуто нису велике. Највећа разлика је у просечној старости активних дневних миграната који путују ка/са простора општине Опово. У општину Опово путује у просеку млађе активно становништво од становништва које са простора ове општине долази да ради у Панчеву. Реч је о разликама које настају првенствено због просечне старости мушке радне снаге. На простор општине Ковачица одлазе да раде жене млађе у односу на оне које са простора Ковачице долазе да раде у општини Панчево, док када је реч о Београду овај однос је обрнут.

\section{Брачни статус}

Брачни статус активних дневних миграната један је од фактора који утиче на правце дневних миграција активног становништва. Нарочито је значајно проучавање утицаја овог обележја на учешће жена у дневној миграцији. Међу радницима дневним мигрантима Панчева већина је у браку (12.045 или 73,6\% од укупног броја дневних миграната). Није у браку 3.265 или $20 \%$ дневних миграната, док је разведених и удовица/удоваца 1.032 или $6,3 \%$. Дивергентни активни дневни мигранти су у већем проценту лица која нису у браку у односу на конвергентне дневне мигранте. Приметна је разлика између конвергентних и дивергентних дневних миграната женског пола 
према брачном статусу, у смислу већег учешћа жена које нису у браку и мањег учешћа жена у браку у дивергентним дневним миграцијама. За дневне мигранте Панчева брачно стање је у интеракцији и са просечном просторном раздаљином дневне миграције у једном правцу, која је мања за жене у браку у односу на жене које нису у браку, али и односу на мушкарце који су у браку (види поглавље 5.2).

Табела 54. Структура активних конвергентних дневних миграната општине Панчево према полу и брачном статусу 2002 , године

\begin{tabular}{|l|c|c|c|c|c|c|}
\hline \multirow{2}{*}{ Брачни статус } & \multicolumn{4}{|c|}{ Пол } & \multicolumn{2}{|c|}{ Укупно } \\
\cline { 2 - 7 } & \multicolumn{2}{|c|}{ Мушки } & \multicolumn{2}{|c|}{ Женски } & \multicolumn{2}{c|}{} \\
\cline { 2 - 7 } & Број & $\%$ & $6 p о j$ & $\%$ & Број & $\%$ \\
\hline Нису у 6раку & 1.589 & 19,6 & 661 & 16,9 & 2.250 & 18,7 \\
\hline У браку & 6.173 & 76,2 & 2.875 & 73,5 & 9.048 & 75,3 \\
\hline Разведени & 75 & 0,9 & 143 & 3,7 & 217 & 1,8 \\
\hline Удови/ удовице & 261 & 3,2 & 227 & 5,8 & 488 & 4,1 \\
\hline Непознато & 4 & 0,0 & 6 & 0,1 & 10 & 0,0 \\
\hline Укупно & 8.102 & $100 \%$ & 3.912 & $100 \%$ & 12.014 & $100 \%$ \\
\hline
\end{tabular}

Извор података: Р3С,2007 Посебна обрада података.

Град Панчево припада мањој групи насеља Општине која више привлаче активне дневне мигранте који су у браку, док изван ових насеља на посао свакодневно путују већином лица која нису у браку. Највећи удео дневних миграната који су у браку има Банатски Брестовац као насеље рада.

Табела 55. Структура активних дивергентних дневних миграната општине Панчево према полу и брачном статусу 2002. године

\begin{tabular}{|l|c|c|c|c|c|c|}
\hline \multirow{2}{*}{ Брачни статус } & \multicolumn{4}{|c|}{ Поп } & \multicolumn{2}{|c|}{ Укупно } \\
\cline { 2 - 7 } & \multicolumn{2}{|c|}{ Мушки } & \multicolumn{2}{|c|}{ Женоки } & \multicolumn{2}{|c|}{} \\
\cline { 2 - 7 } & Број & $\%$ & Број & $\%$ & Број & $\%$ \\
\hline Нису у браку & 607 & 22,1 & 408 & 25,5 & 1.015 & 23,4 \\
\hline У браку & 2.001 & 72,9 & 996 & 62,3 & 2.997 & 69,0 \\
\hline Разведени & 26 & 0,9 & 37 & 2,3 & 63 & 1,5 \\
\hline Удовци/удовице & 106 & 3,9 & 158 & 9,9 & 264 & 6,1 \\
\hline Непознато & 2 & 0,1 & - & - & 2 & 0,1 \\
\hline Укупно & 2.742 & $100 \%$ & 1.599 & $100 \%$ & 4.341 & $100 \%$ \\
\hline
\end{tabular}

Извор података: Р3С,2007 Посебна обрада података

Ако се анализира брачни статус активних дневних миграната према општинама полазишта и одредишта дневне миграције, евидентно је да су активни дневни мигранти који свакодневно путују на релацији општина Панчево - Београд и општина Панчево Ковин у нешто већем проценту самци, у односу на оне дневне мигранте који свакодневно путују са простора Општине у друге општине њеног функционалног подручја. Из општина Ковин и Алибунар у општину Панчево у просеку долази више лица која нису у браку.

\section{Структура дневних миграната према делатности}

Највећи број дневних миграната општине Панчево запослен је у секундарним делатностима (7.707 или $47,1 \%$ ). На другом месту по обиму дневних миграната које запошљавају су терцијарне делатности са 4.200 или $25,7 \%$ дневних миграната, а затим квартарне делатности са 3.425 или 20,9\%. Најмањи број дневних миграната ради у 
примарним делатностима - свега 560 или $3,4 \%$, што је ниже од просека за Војводину (7,3\%) и у складу са привредном структуром Општине.

Табела 56. Структура дневних миграната општине Панчево према делатностима рада 2002. године

\begin{tabular}{|l|c|c|c|c|}
\hline \multicolumn{1}{|c|}{ Делатност } & КРДМ & $\%$ & АРДМ & $\%$ \\
\hline Польопривреда и шумарство & 456 & 3,8 & 114 & 2,6 \\
\hline Прерађивачка индустрија & 5.348 & 44,5 & 968 & 22,3 \\
\hline Грађевинарство & 677 & 5,6 & 463 & 10,7 \\
\hline Трговина & 1.227 & 10,2 & 597 & 13,8 \\
\hline Саобраһај & 774 & 6,4 & 338 & 7,8 \\
\hline Здравство & 771 & 6,4 & 420 & 9,7 \\
\hline Аржавна управа & 747 & 6,2 & 477 & 11,0 \\
\hline Остале делатности & 2.014 & 16,9 & 964 & 22,1 \\
\hline Укупно & 12.014 & $100 \%$ & 4.341 & $100 \%$ \\
\hline
\end{tabular}

Извор података: Р3С,2007 Посебна обрада података.

Доминација индустрије у привреди општине Панчево је фактор који веома привлачи активно становништво а што се огледа и у структури дневних миграционих токова. Простор општине Панчево, захваљујући јаком градском индустријском центру, највише привлачи раднике запослене у секундарном сектору делатности (прерађивачка индустрија). Структура дивергентних дневних миграната према секторима делатности је доста уједначенија са прилично равномерним уделима запослених у секундарним, терцијарним и квартарним делатностима.

И мушкарци и жене дневни мигранти који долазе да раде на простору Општине у највећој мери запослени су у секундарним делатностима. Ови подаци потврђују сазнања из бројне литературе, која упућује да је прерађивачка индустрија сектор са највећим обимом дневне миграције, а нарочито запослени у секторима који подразумевају велике фабрике као што је хемијска индустрија (Eliasson K., U.Lindgren, O.Westerlund, 2003), а да је најмање дневних миграната запослено у пољопривреди, рибарству и шумарству. Структура конвергентних дневних миграната према полу показује да код мушкараца ова делатност доминира, док су жене доста запослене и у терцијарним и квартарним делатностима. Дивергентни дневни мигранти мушког пола највише су запослени у секундарним делатностима, а жене у квартарним делатностима. Највећи број дневних миграната који раде у граду Панчеву запослен је у прерађивачкој индустрији, док радници који из Града путују на посао у неку од београдских општина већином раде у државној управи.

Дневни мигранти запослени у примарним делатностима чине највећи удео у структури дневних миграната који долазе да раде у насељима Долово, Банатски Брестовац, Старчево и Иваново, док Јабука и Панчево привлаче претежно раднике запослене у секундарним делатностима. Висок удео дневних миграната запослених у квартарним делатностима, који долазе да раде у насељима Панчева показује потребу сеоских насеља Општине за просветним и здравственим радницима.

Ако посматрамо дивергентне токове дневних миграција на нивоу насеља, највећи удео дневних миграната запослених у секундарним делатностима има Глогоњ, док највише дневних миграната који раде у терцијарним и квартарним делатностима дају насеља Панчево и Качарево. Само Иваново, у складу са неповољном образовном структуром дневних миграната, не даје ниједног радника дневног мигранта запосленог у квартарним делатностима. У односу на укупно активно становништво Панчева које обавља занимање, изражено је веће учешће запослених дневних миграната у квартарним делатностима, који веһином раде ван простора Општине. 


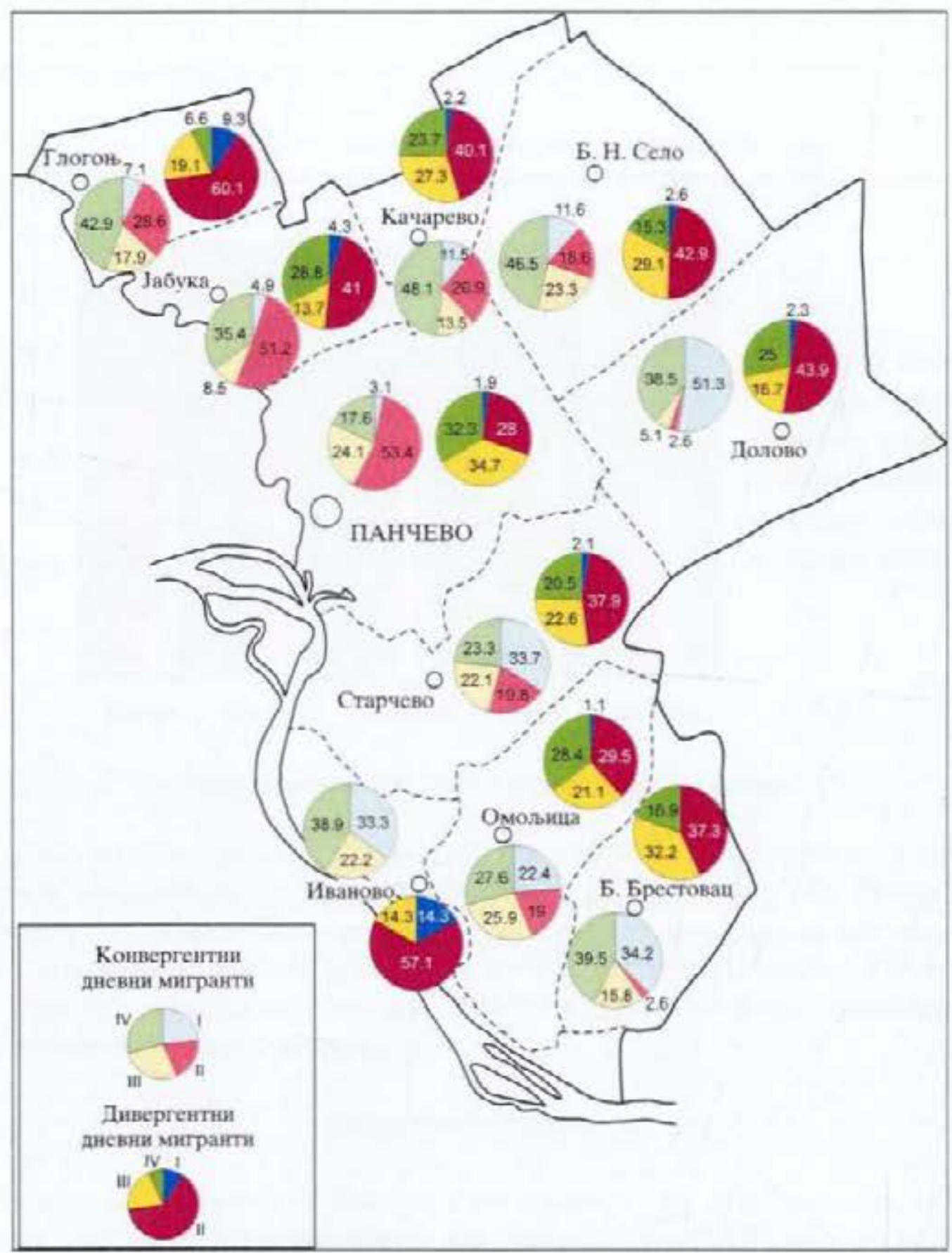

Карта 9. Структура конвергентних и дивергентних активних дневних миграната општине Панчево према секторима делатности рада 2002. године Извор података: Р3С,2007 Посебона обрада података.

У локалним дневним миграпијама, у односу на спољашње, више су заступљени запослени у примарним и секундарним делатностима, док је веће учешће ралника запослених у терцијарним и квартарним делатностима у структури спољних дневних миграната. Знатан удео дневних миграната који из Града путују у друга насеља Општине на посао запослен је у примарним делатностима (чак $18 \%$ ).

У структури дневних миграната према делатности, који са простора других општина долазе да раде на простору општине Панчево, највише запослених у примарним делатностима имају општине Ковин и Ковачица, док са простора општине Алибунар полази највеһи број запослених у терцијарним делатностима.

Становништво запослено у примарним делатностима више свакодневно путује на посао из Панчева на простор суседних општина, него што из ових општина долази да ради у Панчеву. Највећа разлика је у случају општине Ковачица, где у структури радника дневних митраната према сектору делатности рада запослени у примарним делатностима који путују на релацији Ковачица-Панчево чнне $4,5 \%$ од укупне масе 
дневних миграната, а они који путују у супротном смеру $44,3 \%$ од укупног обима дневне миграшије на овој релащији. Нешто мање разлике су за општину Алибунар.

Графикон 8. Активни дневни мигранти општине Панчево према сектору делатности рада $(\%)$ и општини становања рада, 2002. године

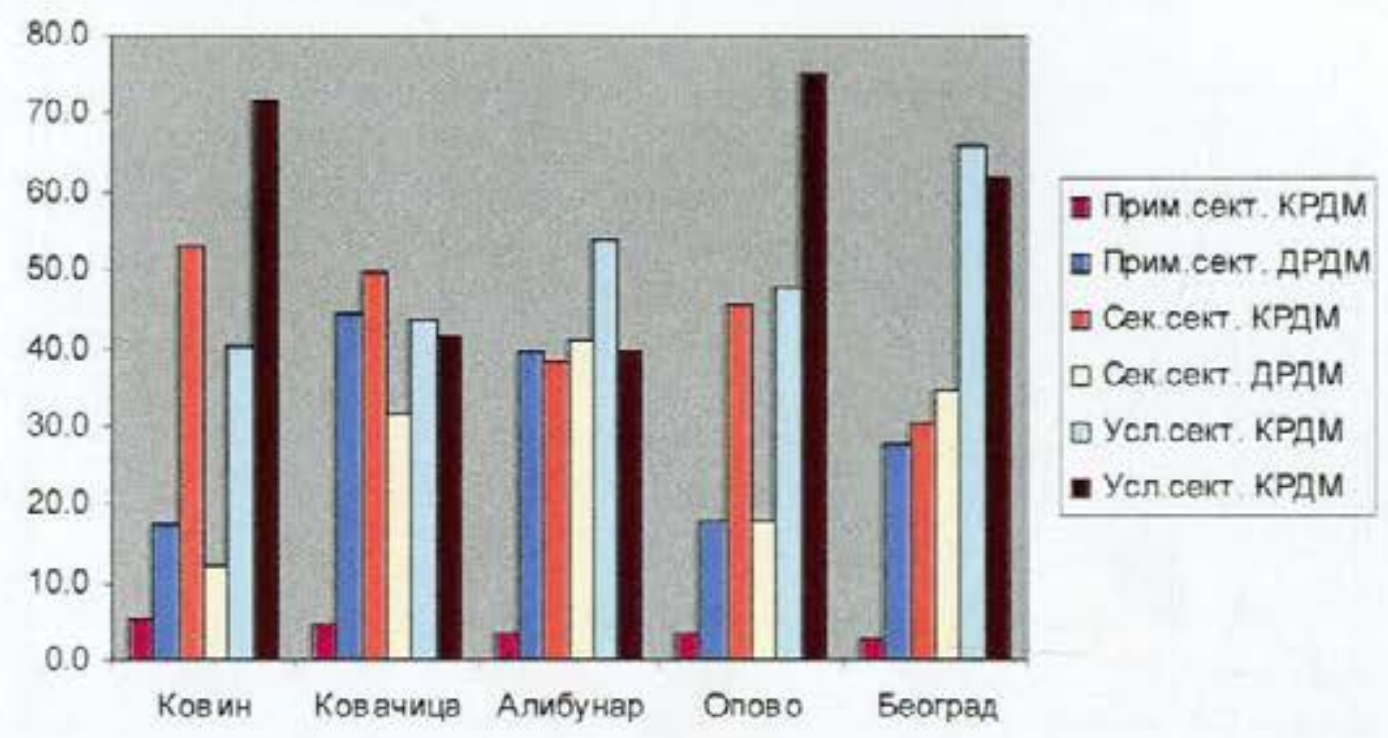

Извор података: Р3С,2007 Посебна обрада података.

Најмање разлике између удела дневних митраната запослених у секундарном, терцијарном и квартарном сектору делатности, а који путују у оба смера на релашији између простора општине Панчево и општнна њеног функшионалног подручја, су у структури мигращионих токова усмерених ка/из Београда. Панчево и Београд дневно размењују готово подједнаке делове активног становништва запосленог у свим секторима делатности осим примарног.

\section{Образовна структура}

У складу са сазнањима миграционе теорије, да образованије становништво уопште више учествује у миграцијама, анализирана је образовна структура активних дневних миграната општине Панчево. Без школе и са завршена 1-3 разреда основне школе је свега 79 или $0,5 \%$ дневних миграната Панчева. Непотпуну основну школу има 213 или 1,3\% дневних миграната, док је основну пколу заврпило 2.972 или 18,2\% дневних миграната. Највише дневних миграната је са завршеном средњом школом (10.432 или $63,8 \%$ дневних миграната), а 2.757 или $16,9 \%$ има више и високо образовање. Жене дневни мигранти су образованије од мушкараца, са учешһем високо и више образованих у укупној популапији жена дневних миграната од $22,3 \%$ у односу на $14,1 \%$ за мушкарце.

Конвергентни активни дневни мигранти општине Панчево имају неповољнију образовну структуру од дивергентних дневних миграната, са знатно мањим уделом више и високо образованих лица, и веһим уделом лица без школе, са непотпуном основном школом и само са основним образовањем. Томе највише доприноси неповољнија образовна структура мушке популашије у односу на женску. Близина Београда омогуһава становништву Панчева које има виши ниво образовања да без високих трошкова миграције искористи предности које пружа Београд у погледу запослења. Зато становништво са вишим и високим образовањем свакодневно више валушта простор Општине ради одласка на посао, него што простор Општине привлачи раднике овог образовног нивоа. 
Највећи удео дневних миграната без школе и са непотпуном основном школом долази на посао у Иваново а одлази из Старчева, Долова и Омољице. Високообразовану ралну снагу највите примају насеља Долово и Банатско Ново Село, док најмањи удео више и високо образованих лица има у структури дневних миграната који полазе из Иванова и Глогоња.

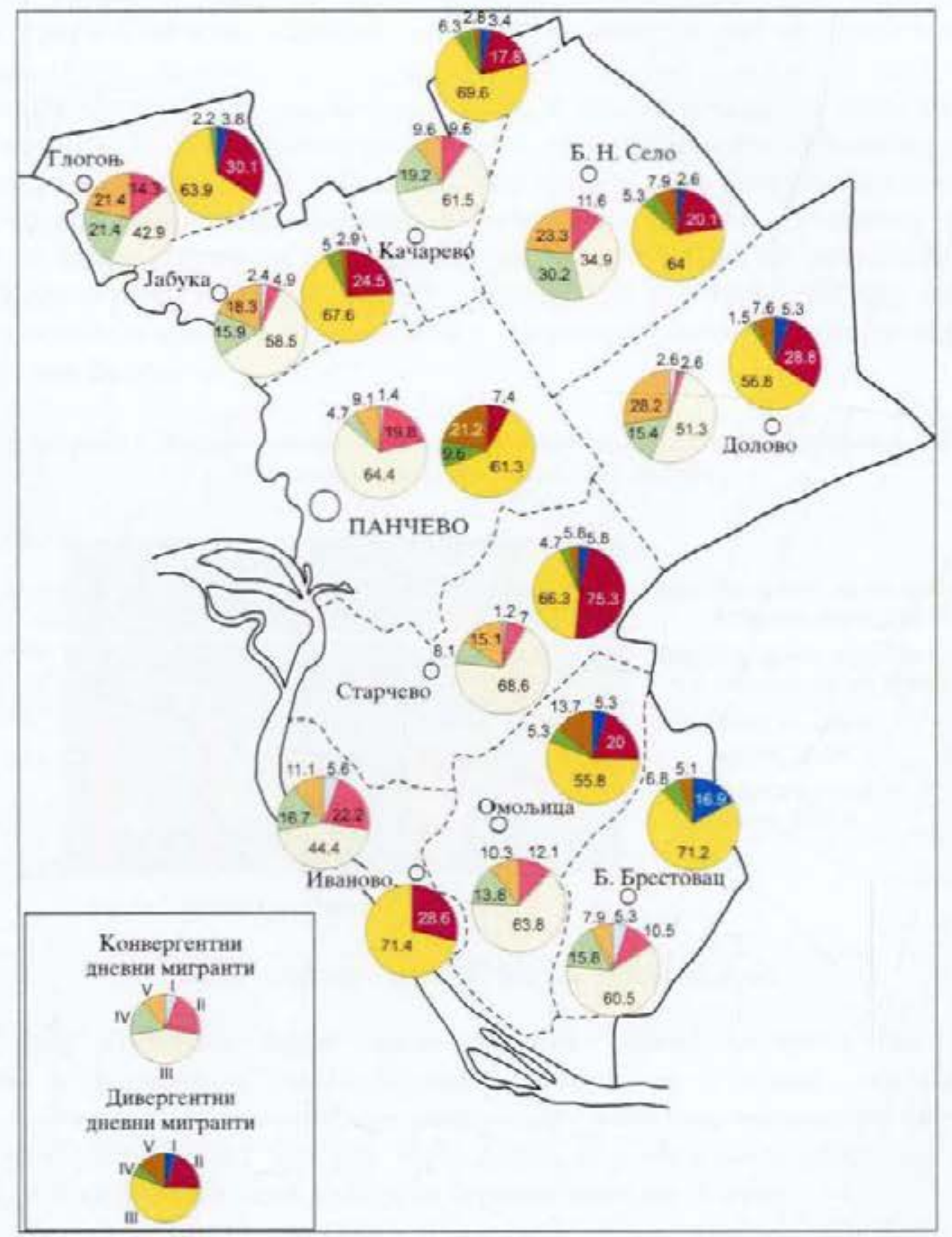

Карта 10. Структура конвергентних и дивергентних активних дневних миграната опттине Панчево према степену школске спреме 2002. године Извор података: Р3С.2007 Посеб̆на обрада података

1 -без школе и непотпуна основна школа

2- основна школа

3- средња школа

4- виша школа

5- висока школа 
Образовна структура дневних миграната града Панчева је повољнија у односу на ниво Општине. Удео дивергентних дневних миграната са високим образовањем износи qак $21,2 \%$. Сва насеља осим општинског центра примају већи број радника са вишом и високом стручном спремом него што из њих одлази на рад у друга насеља. Град прима више локалних дневних миграната без школе, са непотпуном и завршеном само основном школом а мање вањских дневних миграната са овим квалификашијама. Ралници са вишом и високом школом чине $31 \%$ у структури вањских дневних миграната града Панчева, односно свега $6,4 \%$ када је реч о локалним дневним мигрантима.

Дневни мигранти са завршеном вишом и високом школом свакодневно више одлазе на посао из Панчева у суседне општине, него што високообразовани радници са простора ових општина долазе у Панчево. Изузетак је само Београд. Од свих општина које дају раднике општини Панчево, највећи удео ралника са вишим и високим образовањем има у структури дневних миграната који долазе на простор Општине из Београда. Када је реч о токовима дневних миграција са простора Општине, највећи удео радника са вишом и високом спремом има у структури дневних миграционих токова ка Алибунару, чак $38,0 \%$.

\section{Графикон 9. Активни дневни мигранти општине Панчево према образовању (\%) и отштини становања/рада 2002. године}

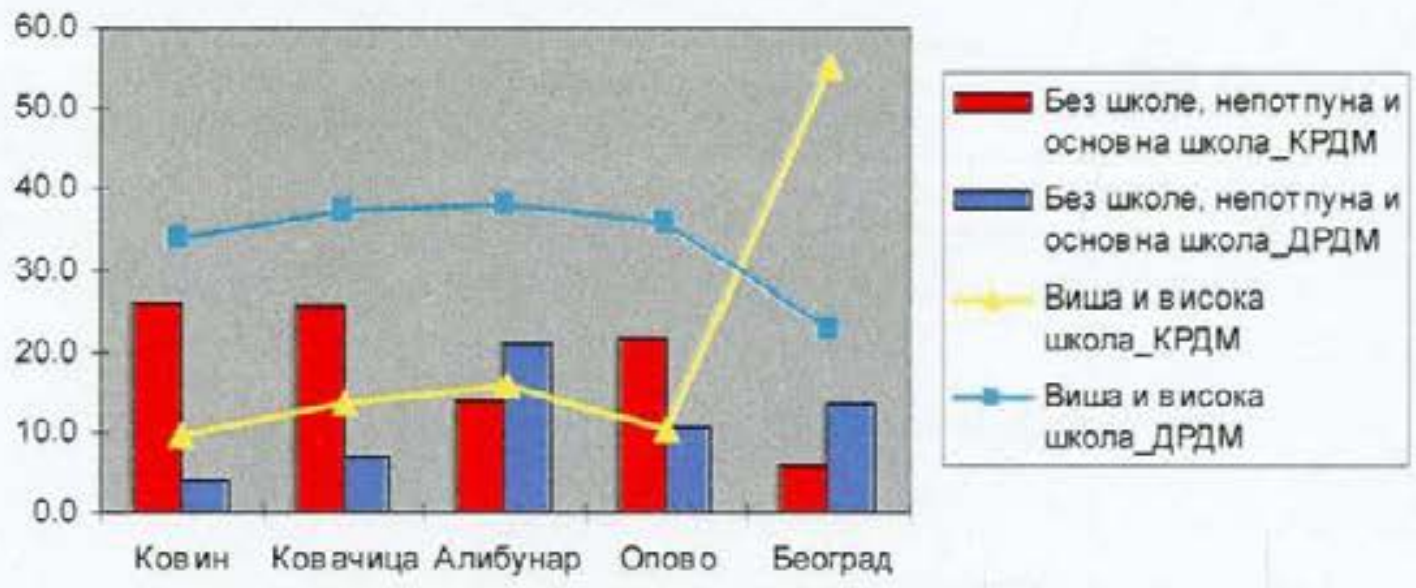

Извор података: Р3С, 2007 Посебна обрада података

Простор Општине више прима активне дневне митранте без школе, са непотпуном и завршеном само основном пколом из суседних општина Ковина, Ковачице и Опова, него што им даје радну снагу ових квалификашија. Обрнуто је за општине Алибунар и Град Београд. Најнеповољнију образовну структуру има радна снага која на простор Општине долази из суседне општине Ковин.

Највећу вредност индекса сличности тј. најмању вредност индекса различитости $^{18}$ конвергентних и дивергентних токова дневних миграција према образовању дневних миграната има насеље Омољица док је обрнуто за насеље Глогоњ. Вредност индекса различитости показује проценат у популацији дневних миграната који иду у смеру ових насеља који би се морао прерасподелити између образовних група да би образовна структура била иста као структура радне снаге која иде из ових насеља.

${ }^{18}$ Види Stone L., 1971. 


\begin{tabular}{|l|c|}
\hline \multicolumn{1}{|c|}{ Територија } & $\begin{array}{c}\text { Индекс сличности } \\
\text { према образовану }\end{array}$ \\
\hline Банатски Брестовац & 82,9 \\
\hline Банатско Ново Село & 59,7 \\
\hline Долово & 65,5 \\
\hline Глогон & 59,3 \\
\hline Иваново & 66,7 \\
\hline Јабука & 71,3 \\
\hline Качарево & 80,3 \\
\hline Омољича & 86,8 \\
\hline Панчево & 82,6 \\
\hline Старчево & 85,0 \\
\hline Укупно & 93,2 \\
\hline
\end{tabular}

Извор података: Р3С,2007 Посебна обрада података.

Оценом насеља становања у којима станују радници Панчева, по принципу бодовања према просечној квалификацији радника дневних миграната ${ }^{19}$, израђен је зонинг по насељима Панчева који потврђује да се мање квалификована радна снага углавном налази даље од града, средње квалификована ближе, а високо квалификована најближе граду, односно у првој зони.

Табела 58. Зонинг насеља Панчева

према просечној квалификацији радника дневних миграната 2002. године

\begin{tabular}{|c|c|c|}
\hline $\begin{array}{c}\text { Број } \\
6 \text { одова }\end{array}$ & Насеље & Зона \\
\hline 19 & Иваново & III \\
197 & Банатски Брестовац & (dо 300 6одова) \\
\hline 312 & Омолица & \\
376 & Долово & II \\
433 & Јабука & (300-600 бодова) \\
504 & Глогон & \\
\hline 609 & Банатско Ново Село & I \\
811 & Старчево & (600-900 бодова) \\
1574 & Качарево & \\
\hline
\end{tabular}

Извор података: Р3С,2007 Посебна обрада података.

Да би се утврдио значај образовне детерминанте процеса дневних миграција и миграциони потенцијал овог подручја извршено је поређење образовних карактеристика активних дневних миграната Панчева (дивергентних и локалних) са образовним карактеристикама укупног активног становништа Општине које обавља занимање (које садржи и не-дневне мигранте). Поређењем структуре активног становништва Општине које обављьа занимање и структуре активног становништва које учествује у дневним миграционим токовима радне снаге потврђена су теоретска сазнања о већој просторној покретљивости образованијег становништва. У активном становништву Општине које обавља занимање, високообразована радна снага чини $9,4 \%$, док се изван простора Општине Панчево ради обављања функције рада свакодневно крећу токови радне снаге са учешћем високообразованих од чак $15,5 \%$.

Када је реч о локалним дневним миграцијама високообразована радна снага учествује у дневним миграцијама са свега $3,3 \%$, док је удео лица са завршеним

\footnotetext{
${ }^{19}$ Види Ž̃agar M., 1959.
} 
основним образовањем и средњим образовањем у токовима локалних дневних миграција чак и изнад удела ових група у квалификационој структури укупног активног становништва Општине које обавља занимање. Највећи удео радника са вишим и високим образовањем који свакодневно путују на посао у оквиру Општине имају насеља Банатско Ново Село и град Панчево.

\section{Структура домаћинстава дневних миграната према поседовању пољопривредног газдинства}

Дневне миграције активног становништва у Србији шездесетих година 20. века, одликовала је двострука радна ангажованост дневних миграната у смислу рада на послу и рада на пољопривредном имању. Смањивањем броја и променама у структури (сенилизацијом и феминизацијом) пољопривредног становништва, поред извора радне снаге за трансфер у непољопривредне делатности смањио се и број дневних миграната делимично ангажованих у пољопривреди.

Године 2002. удео домаһинстава без пољопривредног газдинства у укупном износио је $80 \%$ на нивоу општине Панчево, што је било изнад просека за Војводину. Од укупног броја дневних миграната Општине 5.302 или $32,4 \%$ поседује пољопривредно газдинство, док веһина (11.053 или $67,6 \%)$ не поседује пољопривредно газдинство. У структури конвергентних дневних миграната однос оних који поседују и не поседују пољопривредно газдинство је $37,9 \%$ на према $62,1 \%$, док је у структури дивергентних дневних миграната знатно већи удео лица без пољопривредног газдинства $(82,7 \%)$. На то утичу чињенице да највећи број дивергентних дневних миграната полази из града Панчева, те да већина других насеља Општине има удео дневних миграната са пољопривредним домаһинством од око $40 \%$.

Табела 59. Структура домаһинстава дневних миграната општине Панчево према поседовању пољопривредног газдинства 2002. године

\begin{tabular}{|c|c|c|c|c|c|c|c|c|c|c|}
\hline \multirow{2}{*}{ Hacere } & \multirow{2}{*}{$\begin{array}{l}\text { Укупно } \\
\text { КРДМ }\end{array}$} & \multicolumn{2}{|c|}{$\begin{array}{l}\text { Ca noљsonp. } \\
\text { газдинством }\end{array}$} & \multicolumn{2}{|c|}{$\begin{array}{l}\text { Без noльonp. } \\
\text { газдинства }\end{array}$} & \multirow{2}{*}{$\begin{array}{l}\text { Укупно } \\
\text { АРДМ }\end{array}$} & \multicolumn{2}{|c|}{$\begin{array}{l}\text { Ca noљonip. } \\
\text { газдинством }\end{array}$} & \multicolumn{2}{|c|}{$\begin{array}{l}\text { Без польопр. } \\
\text { газдинства }\end{array}$} \\
\hline & & $6 \mathrm{poj}$ & $\%$ & $6 p o j$ & $\%$ & & 6poj & $\%$ & 6poj & $\%$ \\
\hline Б. Брестопац & 38 & 13 & 34,2 & 25 & 65,8 & 59 & 33 & 55,9 & 26 & 44,1 \\
\hline 5. Hoso Ceno & 43 & 6 & 14,0 & 37 & 86,0 & 189 & 89 & 47,1 & 100 & 52,9 \\
\hline Долово & 39 & 16 & 41,0 & 23 & 59,0 & 132 & 59 & 44,7 & 73 & 55,3 \\
\hline Гnorote & 28 & 12 & 42,9 & 16 & 57,1 & 183 & 76 & 41,5 & 107 & 58,5 \\
\hline Иваново & 18 & 6 & 33,3 & 12 & 66,7 & 7 & 3 & 42,9 & 4 & 57,1 \\
\hline Јабука & 82 & 14 & 17,1 & 68 & 82,9 & 139 & 69 & 49,6 & 70 & 50,4 \\
\hline Качарево & 52 & 4 & 7,7 & 48 & 92,3 & 494 & 123 & 24,9 & 371 & 75,1 \\
\hline Омолица & 58 & 11 & 19,0 & 47 & 81,0 & 95 & 46 & 48,4 & 49 & 51,6 \\
\hline Панчево & 11.570 & 4.448 & 38,4 & 7.122 & 61,6 & 2.853 & 199 & 7,0 & 2.654 & 93,0 \\
\hline Старчево & 86 & 23 & 26,7 & 63 & 73,3 & 190 & 52 & 27,4 & 138 & 72,6 \\
\hline Укупно & 12.014 & 4.553 & 37,9 & 7.461 & 62,1 & 4.341 & 749 & 17,3 & 3.592 & 82,7 \\
\hline
\end{tabular}

Извор података: Р3С,2007 Посебна обрада података.

Највећи процентуални удео радника који поседују пољопривредно газдинство имају насеља Банатски Брестовац и Јабука (преко $50 \%$ ), а најмањи градска насеља Панчево, Старчево и Качарево. Може се закључити да су активни дневни мигранти становници општине Панчево, осим у граду Панчеву, наставили у одређеној мери да се баве пољопривредом као допунском делатношћу, било због допунског извора прихода, или због сопствених потреба. Исто је и у случају дневних миграната који долазе да раде у Глогоњу и Долову, имајући у виду податке о структури домаћинстава ових миграната 
према поседовању пољопривредног газдинства, али и доминантне правце ових токова (Опово-Глогоњ, Ковин-Долово).

За запослене дневне мигранате који свакодневно путују у оквиру граница општине Панчево карактеристична је већа везаност за пољопривредно домаһинство, у три насеља (Банатско Ново Село, Долово и Глогоњ) већину чине локални дневни мигранти који поседују пољопривредно газдинство. То је и логично имајуһи у виду да су ово једина панчевачка насеља која су имала преко $50 \%$ домаһинстава са пољопривредним газдинством према Попису становништва из 2002. године.

Графикон 11. Активни дневни мигранти опитине Панчево према поседовању пољопривредног газдинства (\%) и општини становања/рада 2002, године

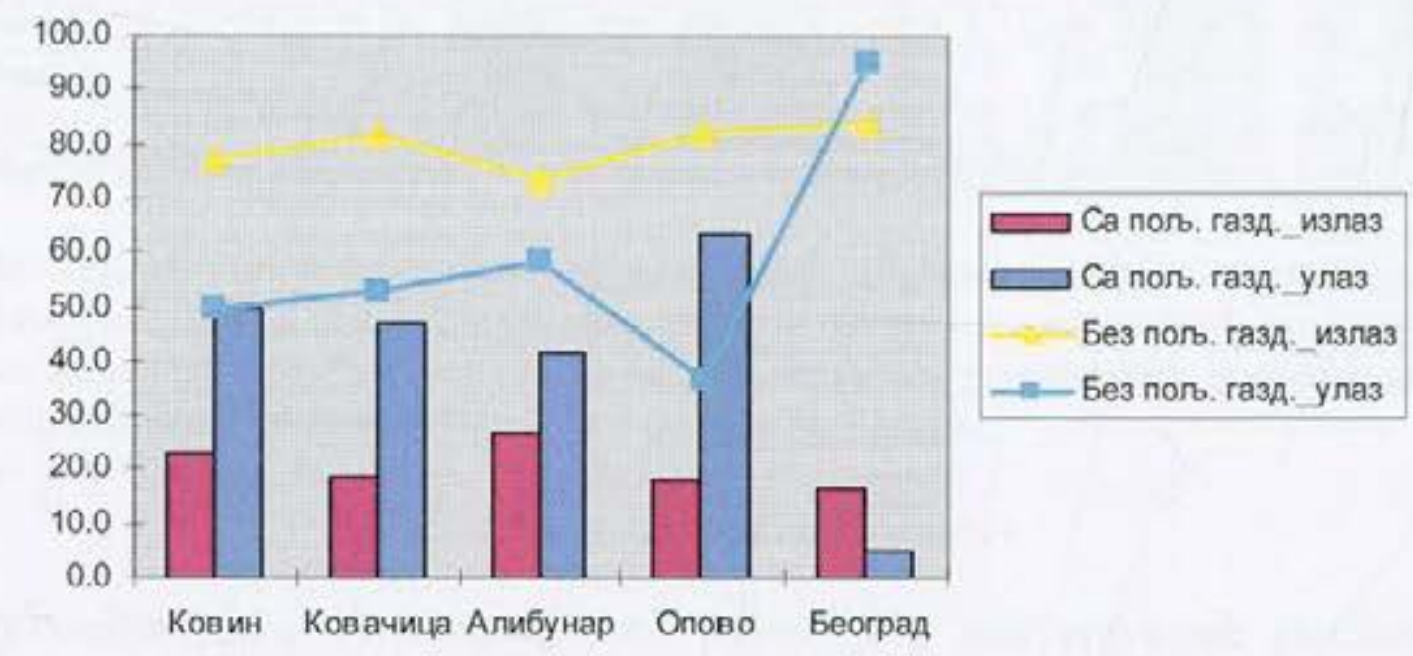

Извор података: РЗС,2007 Посебна обрада података.

Дневни мигранти који долазе са простора других општина да раде у неком од насеља општине Панчево већином не поседују пољопривредно газдинство, осим у случају општине Опово, где је однос дневних миграната са и без пољопривредног газдинства $63,5 \%$ на према $36,5 \%$. У структури дивергентних дневних миграната, највеһи удео дневних миграната са пољопривредним газдинством јесте у структури дневних миграната који живе на територији општини Панчево, а раде на простору општине Алибунар (26,8\%). Удео дневних миграната са пољопривредним газдинством, који свакодневно путују на посао ван простора општине Панчево креће се од $16 \%$ до $27 \%$ од укупног обима појединачног тока дневне миграције у одређеном смеру.

\section{С'труктура дневних миграната према стамбеном статусу}

Чак 15.343 или 93,8\% дневних миграната општине Панчево живи у стамбеном објекту који је у власништву његове породице. То је потврда сазнања и других аутора (Hanson S., G.Pratt,1988) да се власници стамбених јединица/објеката чешһе одлучују на овај облик миграције у односу на дефинитивну миграцију. У случају конвергентних активних дневних миграната 11.539 или $96 \%$ има решено стамбено питање, док свега 458 дневних миграната или $3,8 \%$ живе као подстанари. Када је реч о дивергентним дневним мигрантима, већи је удео подстанара, те је претходни однос 3.920 или 90,3\% на према 404 или $9,6 \%$. 
Табела 60. Структура домаһинстава дневних миграната општине Панчево према стамбеном статусу 2002. године

\begin{tabular}{|c|c|c|c|c|c|c|c|c|c|c|}
\hline \multirow{2}{*}{ Hacere } & \multirow{2}{*}{$\begin{array}{c}\text { Укупно } \\
\text { КРДМ }\end{array}$} & \multicolumn{2}{|c|}{ Власник } & \multicolumn{2}{|c|}{ Подстанар } & \multirow{2}{*}{$\begin{array}{c}\text { Укупно } \\
\text { ДРДМ }\end{array}$} & \multicolumn{2}{|c|}{ Власник } & \multicolumn{2}{|c|}{ Подстанар } \\
\hline & & $6 p o j$ & $\%$ & 6poj & $\%$ & & $6 p o j$ & $\%$ & 6poj & $\%$ \\
\hline Б. Брестовац & 38 & 36 & 93,0 & 2 & 5,3 & 59 & 53 & 89,8 & 2 & 10,1 \\
\hline Б. Ново Село & 43 & 40 & 94,7 & 3 & 6,9 & 189 & 158 & 91,1 & 14 & 8,9 \\
\hline Аолово & 39 & 38 & 97,4 & 1 & 2,5 & 132 & 111 & 93,7 & 7 & 6,3 \\
\hline Tnorots & 28 & 26 & 92,8 & 2 & 7,1 & 183 & 163 & 89,1 & 15 & 10,9 \\
\hline Иеаново & 18 & 17 & 94,4 & 1 & 5,5 & 7 & 6 & 85,7 & 0 & 0 \\
\hline Ja6yкa & 82 & 79 & 96,4 & 3 & 3,6 & 139 & 121 & 87,0 & 3 & 12,9 \\
\hline Качарево & 52 & 49 & 94,2 & 3 & 5,8 & 494 & 451 & 93,1 & 31 & 6,9 \\
\hline Oмольица & 58 & 54 & 93,1 & 4 & 6,9 & 95 & 77 & 97,4 & 2 & 2,6 \\
\hline Панчево & 11.570 & 11.134 & 96,3 & 434 & 3,7 & 2.853 & 2.530 & 86,1 & 315 & 13,9 \\
\hline Crapueso & 86 & 66 & 94,2 & 5 & 5,8 & 190 & 152 & 88,7 & 15 & 7,9 \\
\hline Укупно & 12.014 & 11.539 & 96,0 & 458 & 3,8 & 4.341 & 3.920 & 90,3 & 404 & 10,3 \\
\hline
\end{tabular}

Разлику до $100 \%$ чини непознато

Нзвор података: Р3С,2007 Посебна обрада података.

Из града Панчева полази највећи број дневних миграната са нерешеним стамбеним статусом, и они већином свакодневно путују на посао у неку од београдских општина. Један од могућих разлога за овакву структуру токова јесу знатно повољније цене изнајмљивања станова у Панчеву у односу на Београд.

\section{Породице дневикх миграната}

У литератури о миграцијама често се доводи у везу структура домаһинства и породице са одређеним типом миграције. Бројнија породица из више разлога може да отежава дефинитивно пресељење, па у том случају може доћи до учешћа једног или чак два члана породице у дневној миграцији. Ради испитивања утицаја породичних фактора на процес дневне миграције посебно су обрађени подаци о породицама активних дневних миграната који станују/раде на простору општине Панчево. Породица је дефинисана као заједница која се састоји из брачног пара, или од родитеља (оба или једног) и њихове деце која нису у браку, у контесту важеће дефиниције породице која је прихваћена од стране Републичког завода за статистику. У складу са досадашњим теоретским сазнањима о олакшавајућим/отежавајућим факторима утицаја на процес дневне миграције узете су у обзир следеће породичне карактеристике: да ли свакодневно до посла ван насеља становања путује један или оба супружника, да ли су запослени обоје супружника или један, да ли у породици има дете предшколског узраста и да ли у домаһинству станује још неко ко није члан нуклеарне породице.

У дневним миграцијама општине Панчево учествује укупно 10.348 породица активних дневних миграната. У већини породица у дневној миграцији учествује један супружник (7.757 или $75 \%$ породица), а оба супружника у 2.591 породици или $25 \%$ породица. У случају када путује један супружник то је у већини случајева мушкарац $(77,4 \%)$. Ако у породици има дете млађе од седам година процентуални удео породица у којима оба супружника учествују у дневним миграцијама се смањује и у том случају најмањи је удео породица у којима путује само жена. У највећем броју домаћинстава дневних миграната не живи нико осим чланова нуклеарне породице (брачни пар са децом $85 \%$ ), док у $15 \%$ домаһинстава поред чланова породице живе и други укућани (вишегенерацијско домаћинство). То је у складу са сазнањима да су готово две трећине домаћинстава у Војводини 2002. године чинила једнопородична домаһинства без других чланова. Подаци о породицама у Војводини према попису 2002. године показују 
да су када је реч о породицама са децом заједнице где су и мушкарац и жена активни и обављају занимање заступљене са $40 \%$ (Кубуровић А.,2006). У случају дневних миграната општине Панчево породице са двоје запослених заступљене су у нешто већој мери $(49,4 \%)$.

у породицама дивергентних дневних миграната општине Панчево углавном у дневној миграцији учествује један супружник. Свега у случају 259 или $9,5 \%$ породица активних дневних миграната који живе на простору општине Панчево а раде ван простора општине Панчево путују оба супружника. Када је реч о породицама активних дневних миграната који раде на територији општине Панчево већи је удео породица у којима оба супружника учествују у дневној миграцији у односу на дивергентне (2.332 породице, или $30,6 \%$ ). Када један супружник свакодневно путује до посла у друго насеље најчешће је то мушкарац, док ако је један од супружника незапослен углавном је то жена. Супруге нешто више учествују у дневним миграцијама радне снаге ван простора општине Панчево. У случају када су оба супружника запослена и путује један супружник, у две трећине породица конвергентних дневних миграната је то мушкарац, а у случају дивергентних дневних миграната однос мушкараца и жена је $58 \%$ на према $42 \%$. Поред породичних обавеза које сигурно у одређеној мери утичу на мање учешће жена/супруга у дневној миграцији, један од разлога за овакву структуру дневних миграционих токова јесте и структура привреде, како на простору Oпштине, тако и других општина панчевачког функционалног подручја, као и размештај тзв. женских послова. Највећи обим дневних миграција активног женског становништва са простора општине Панчево смера је према Београду, који је центар терцијарних и квартарних делатности у којима се већином запошљавају жене.

Већина породица дневних миграната нема децу предшколског узраста. Деца су више ограничење за дневну миграцију у случају конвергентних дневних миграција, где је у том случају приметна мања дневна покретљивост жена, те ако обоје супружника, или само жена припадају категорији активних дневних миграната, мањи је удео породица са децом предшколског узраста. Ако породице имају децу предшколског узраста проценат жена које путују у случају да путује само један супружник износи у случају конвергентних дневних миграција $14,3 \%$ а у случају дивергентних $22,1 \%$. Ако породице немају децу предшколског узраста овај однос је $21,7 \%$ на према $31,6 \%$. У структури породица како конвергентних, тако и дивергентних токова дневних митрација општине Панчево највећи је удео деце предшколског узраста у породицама у којима путује само мушкарац. Евидентно је да деца предшколског узраста, као што је и очекивано, имају битан утицај на учешће жена у дневном миграционом процесу

Домаћинства дневних миграната Панчева претежно чине нуклеарне породице (83,9\% за конвергентне дневне мигранте, и $88,5 \%$ за дивергентне дневне мигранте). То је још више изражено уколико обоје супружника учествује у дневној миграцији, а што је супротно сазнањима (види Lee B.S., J.Mc Donald ,2003) да присуство још неког члана домаћинства позитивно утиче на мобилност жена, док потврђује сазнања других аутора (Hanson S., G.Pratt, 1995, према Cristaldi F., 2005) о томе да овај фактор нема утицаја на дневну просторну покретљивост жена. Породице активних дневних миграната који раде на територији општине Панчево имају веһи удео проширених домаћинстава од породица активних дневних миграната који станују на простору Општине. У случају конвергентних дневних миграција, ако путује један супружник, то су жене у $17,8 \%$ случајева односно $19,8 \%$ у зависности од тога да ли још неко живи у домаћинству. Када је реч о дивергентним дневним мигрантима ако путује један супружник, то су жене у $26,2 \%$ случајева, односно $29,5 \%$ у зависности од тога да ли још неко живи у домаћинству. И када је реч о конвергентним и када је реч о дивергентним дневним мигрантима жене су, супротно очекивањима, мање миграционо активне уколико у 
домаћинству живи још неки члан осим нуклеарне породице. Може се претпоставити да уколико у домаћинству живе још неки чланови осим нуклеарне породице да су то најчешће родитељи неког од супружника (баке и деке). Њихово присуство је, према неким истраживањима, позитивно утицало на учешће и раздаљину дневне миграције запослених удатих жена које су мајке, јер су се ови чланови показали као помажући чланови домаћинства (Lee B.S., J.Mc Donald,2003). У нашем случају је супротно, те можемо сматрати да присуство додатних чланова у домаћинству отежава дневну мобилност жена из разлога што је реч о старим или болесним лицима, на шта делимично утиче и константно померање старосне границе за одлазак радника у пензију.

Табела 61. Породице активних дневних миграната који рале на територији општине Панчево, према различитим обележјима 2002. године

\begin{tabular}{|c|c|c|c|c|c|c|c|c|c|c|c|c|c|c|}
\hline \multirow{3}{*}{$\begin{array}{l}\text { Породице } \\
\text { КРДМ-а }\end{array}$} & \multirow{2}{*}{\multicolumn{2}{|c|}{ Укупно }} & \multicolumn{4}{|c|}{$\begin{array}{c}\text { Да ли је супружник } \\
\text { запослен }\end{array}$} & \multicolumn{4}{|c|}{$\begin{array}{c}\text { Да ли имају децу млађу од } \\
7 \text { година }\end{array}$} & \multicolumn{4}{|c|}{$\begin{array}{c}\text { Да ли у домаһинству живи } \\
\text { још неко ко није члан } \\
\text { породице }\end{array}$} \\
\hline & & & \multicolumn{2}{|c|}{ не } & \multicolumn{2}{|c|}{ да } & \multicolumn{2}{|c|}{ He } & \multicolumn{2}{|c|}{ да } & \multicolumn{2}{|c|}{ не } & \multicolumn{2}{|c|}{ да } \\
\hline & Број & $\%$ & Бpoj & $\%$ & Бpoj & $\%$ & Бpoj & $\%$ & Броj & $\%$ & Број & $\%$ & Броj & $\%$ \\
\hline Укупно & 7.624 & 100 & 4.051 & 53,1 & 3.573 & 46,9 & 5.540 & 72,7 & 2.084 & 27,3 & 6.398 & 83,9 & 1.226 & 16,1 \\
\hline $\begin{array}{l}\text { Путује } \\
\text { једно }\end{array}$ & 5.292 & 69,4 & 4.018 & 75,9 & 1.274 & 24,1 & 3.714 & 70,2 & 1.578 & 29,8 & 4.409 & 83,3 & 883 & 16,7 \\
\hline Путује муж & 4.260 & 80,5 & 3.463 & 86,2 & 797 & 62,5 & 2.908 & 68,3 & 1.352 & 31,7 & 3534 & 83,0 & 726 & 17,0 \\
\hline Путује жена & 1.032 & 19,5 & 555 & 13,8 & 477 & 37,5 & 806 & 78,1 & 226 & 21,9 & 875 & 84,8 & 157 & 15,2 \\
\hline $\begin{array}{l}\text { Пyтyjy } \\
\text { o6oje }\end{array}$ & 2.332 & 30,6 & 0 & 0,0 & 2.299 & 98,6 & 1.826 & 78,3 & 506 & 21,7 & 1.989 & 85,3 & 343 & 14,7 \\
\hline
\end{tabular}

Извор података: Р3С,2007 Посебна обрала података.

Ако је и супружник дневног мигранта запослен, само један од супружника је дневни мигрант за 35,6\% породица ковергентних активних дневних миграната, а обоје у $64,3 \%$ породица. Уколико породица има децу млађу од седам година свакодневно путује један супружник у $75,7 \%$ случајева, а обоје у $24,3 \%$. Уколико нема деце овог узраста однос је $67,0 \%$ на према $33,0 \%$. Пошто су жене углавном други запослени, може се закључити да је просторна покретљивост жена које учествују у конвергентним дневним миграцијама општине Панчево знатно условљена децом предшколског узраста, те учешће жена у дневној миграцији варира чак и до $10 \%$, у зависности од овог фактора. Ако у домаћинству живи још неко ко није члан уже породице, свакодневно путује један супружник у $72,0 \%$ случајева, а обоје у $28,0 \%$. Уколико нема других чланова домаћинства овај однос је $68,9 \%$ на према $31,1 \%$.

За $83,2 \%$ породица дивергентних активних дневних миграната, ако је и супружник дневног мигранта запослен само једно је дневни мигрант, а обоје у $20,1 \%$ породица. Присуство деце предшколског узраста нема већег значаја за дивергентну дневну миграцију. Уколико у породици живе деца млађа од седам година свакодневно путује један супружник у $90,2 \%$ случајева, а обоје у $9,7 \%$, док уколико нема деце овог узраста поменути однос је $90 \%$ на према $9,4 \%$. Ако у домаћинству дневног мигранта живи још неко ко није члан уже породице, свакодневно путује до посла ван насеља становања један супружник у $91,1 \%$ случајева, а обоје у $8,9 \%$ случајева. Уколико нема других чланова домаћинства овај однос је $90,4 \%$ на према $9,6 \%$. 
Табела 62. Породице активних дневних миграната који живе на територији општине Панчево, а раде ван општине Панчево, према различитим обележјима 2002. године

\begin{tabular}{|c|c|c|c|c|c|c|c|c|c|c|c|c|c|c|}
\hline \multirow{3}{*}{$\begin{array}{l}\text { Породице } \\
\text { АРДМ-а }\end{array}$} & \multirow{2}{*}{\multicolumn{2}{|c|}{ Укупно }} & \multicolumn{4}{|c|}{ Да ли је супружник запослен } & \multicolumn{4}{|c|}{$\begin{array}{c}\text { Да ли имају децу млаһ)у од } \\
7 \text { година }\end{array}$} & \multicolumn{4}{|c|}{$\begin{array}{c}\text { Да ли у домаћинству живи } \\
\text { још неко ко није члан } \\
\text { породиче }\end{array}$} \\
\hline & & & \multicolumn{2}{|c|}{ He } & \multicolumn{2}{|c|}{ да } & \multicolumn{2}{|c|}{ He } & \multicolumn{2}{|c|}{ да } & \multicolumn{2}{|c|}{ He } & \multicolumn{2}{|c|}{ да } \\
\hline & Број & $\%$ & Број & $\%$ & Број & $\%$ & Бpoj & $\%$ & Броj & $\%$ & Бpoj & $\%$ & Бpoj & $\%$ \\
\hline Укупно & 2.724 & 100 & 1.179 & 43,3 & 1.545 & 56,7 & 1.962 & 72,0 & 762 & 28,0 & 2.410 & 88,5 & 314 & 11,5 \\
\hline $\begin{array}{l}\text { Путује } \\
\text { једно }\end{array}$ & 2.465 & 90,5 & 1.179 & 47,8 & 1.286 & 52,2 & 1.777 & 72,1 & 688 & 27,9 & 2.179 & 88,4 & 286 & 11,6 \\
\hline Путује мужк & 1.746 & 70,8 & 1.000 & 84,8 & 746 & 58,0 & 1.215 & 69,6 & 531 & 30,4 & 1535 & 87,9 & 211 & 12,1 \\
\hline Путује жена & 719 & 29,2 & 179 & 15,2 & 540 & 42,0 & 562 & 78,2 & 157 & 21,8 & 644 & 89,6 & 75 & 10,4 \\
\hline $\begin{array}{l}\text { П人yryjy } \\
\text { o6oje }\end{array}$ & 259 & 9,5 & 0 & 0,0 & 259 & 100,0 & 185 & 71,4 & 74 & 28,6 & 231 & 89,2 & 28 & 10,8 \\
\hline
\end{tabular}

Извор података: Р3С,2007 Посебна обрада података.

Посматрано на нивоу насеља учешће породица у којима су оба супружника дневни мигранти највеће је (13,3\%) у случају породица које живе у Качареву а раде ван овог насеља. Највеһе учешће породица са децом млађом од седам година у структури породица дневних миграната (више од једне трећине од укупног броја породица) имају насеља Старчево и Долово, док је највећи удео проширених домаћинстава дневних миграната у Омољици $(18,8 \%)$. Највећи удео дневних миграната који живе у проширеним домаћинствима ради у Иванову $-16,7 \%$.

Само у случају београдских општина из више од половине породица из којих дневни мигранти долазе да раде на простор општине Панчево путују оба супружника. Са простора општине Панчево највећи удео породица из којих оба супружника путују до места рада у другој општини јесте у структури дневних миграционих токова правца општина Панчево-општина Алибунар. Када путује само један супружник, то је већином мушкарац, а у већем проценту су жене само када је реч о путовању на посао у општину Ковин. Анализа дневних миграната на нивоу општина са којима Панчево дневно размењује радну снагу показује да је највећи удео проширених породица у структури активних дневних миграната који долазе из Опова у неко од насеља општине Панчево. То је и логично имајући у виду да када је реч и о укупном становништву општине Опово чак $23,2 \%$ домаћинстава има пет и више чланова, што је изнад просека за подручје Баната и Војводине (Р3С,2004е).

Табела 63. Породице активних дневних миграната који живе и раде на простору општине Панчево, према броју деце предшколског узраста у породици 2002. године

\begin{tabular}{|c|c|c|c|c|}
\hline \multirow{2}{*}{$\begin{array}{c}\text { Број деце } \\
\text { до седам } \\
\text { година старости }\end{array}$} & \multicolumn{2}{|c|}{ Раде у Панчеву } & \multicolumn{2}{|c|}{ Станују у Панчеву } \\
\hline & $\begin{array}{c}\text { Број } \\
\text { породица }\end{array}$ & $\begin{array}{l}\text { \% од укупног } \\
\text { броја породица }\end{array}$ & $\begin{array}{c}\text { Број } \\
\text { породица }\end{array}$ & $\begin{array}{l}\text { \% од укупног } \\
\text { броја породица }\end{array}$ \\
\hline 0 & 5.541 & 72,7 & 1.963 & 72,1 \\
\hline 1 & 1.524 & 20,0 & 559 & 20,5 \\
\hline 2 & 522 & 6,8 & 189 & 6,9 \\
\hline 3 & 32 & 0,4 & 12 & 0,4 \\
\hline 4 & 6 & 0,1 & 2 & 0,1 \\
\hline & 7.624 & 100,0 & 2.724 & 100,0 \\
\hline
\end{tabular}

Извор података: Р3С,2007 Посебна обрада података. 
Структура токова конвергентних и дивергентних дневних миграција према броју деце предшколског узраста у породици дневног миграната прилично је уједначена. Највећи број породица са децом до седам година старости има једно дете овог узраста. Породице дневних миграната које имају више од троје деце предшколског узраста већином живе у Качареву и најчешће из њих путује само мушкарац на посао у Београд. У структури токова локалних дневних миграната највећи број дневних миграната у чијим породицама има четворо или троје деце предшколског узраста путује локално из Старчева, Долова или Банатског Новог Села у град Панчево. Највећи удео породица са децом предшколског узраста има у структури дневних миграционих токова активног становништва који долазе са простора општине Алибунар, док из Панчева највећи удео породица са децом овог узраста има у структури дневних миграционих токова ка Београду.

\section{3 Анализа везе између дневне и дефинитивне миграције (миграционе карактеристике дневних митраната)}

На простору општине Панчево токови дневних миграција већи су од унутрашњих миграционих токова, па отуда и значај проучавања везе између ова два облика просторне покретљивости становништва. Просечан годишњи миграциони салдо на простору Општине (за период 1991-2002.год.) износи 7.678, док је у дневним миграцијама 2002. године учествовало чак 18.690 дневних миграната. За потребе испитивања везе између дневне и дефинитивне миграције на примеру Панчева, полазећи од хипотезе да становништво које је већ учествовало у неком облику просторне покретљивости има већу вероватноћу за учешћем у дневној миграцији од тзв. стабилног дела популације, извршена је анализа дневних миграната према миграционом статусу тј. испитано је да ли је миграциони потенцијал дневних мигранта функционално везан за претходне миграције и да ли особе са претходним миграционим искуством више учествују у дневној миграцији. Од укупног броја активних дневних миграната дневног урбаног система Панчева нешто више су алохтони (8.409 или $51,4 \%)$, од аутохтоних (7.946 или $48,6 \%$ ). Преовладавање алохтоног становништва у дневним миграцијама активног становништва општине Панчево потврда је теоретских сазнања о вези између различитих облика миграционих кретања. У структури конвергентних дневних миграната $52,4 \%$ су аутохтони, а $47,6 \%$ алохтони, док је у случају дивергентних дневних миграната већа разлика у корист алохтоних миграната, и овај однос износи $38 \%$ на према $62 \%$. Насеља Општине, са изузетком општинског центра, привлаче већином алохтоне дневне мигранте. Једино у структури дневних миграната који свакодневно долазе на посао у град Панчево преовладава аутохтоно становништво, што се одражава на укупну структуру конвергентних дневних миграната према миграционим обележјима. У дивергентним дневним миграцијама високо учешһе аутохтоног становништва имају насељь Јабука, Качарево и Банатски Брестовац, док из насеља Банатско Ново Село, Долово, Глогоњ, Панчево и Старчево до посла, свакодневно, у већој мери путује алохтоно становништво. Највећи удео досељених у структури дивергентних дневних миграната имају становници Града Панчева $(69 \%)$ и Старчева (67\%). Од 7.391 дневног мигранта града Панчева највећи број досељен је из друге републике/покрајине (2.584 или $34,9 \%$ ) а затим из бивших југословенских република (2.255 или $30,5 \%)$. 


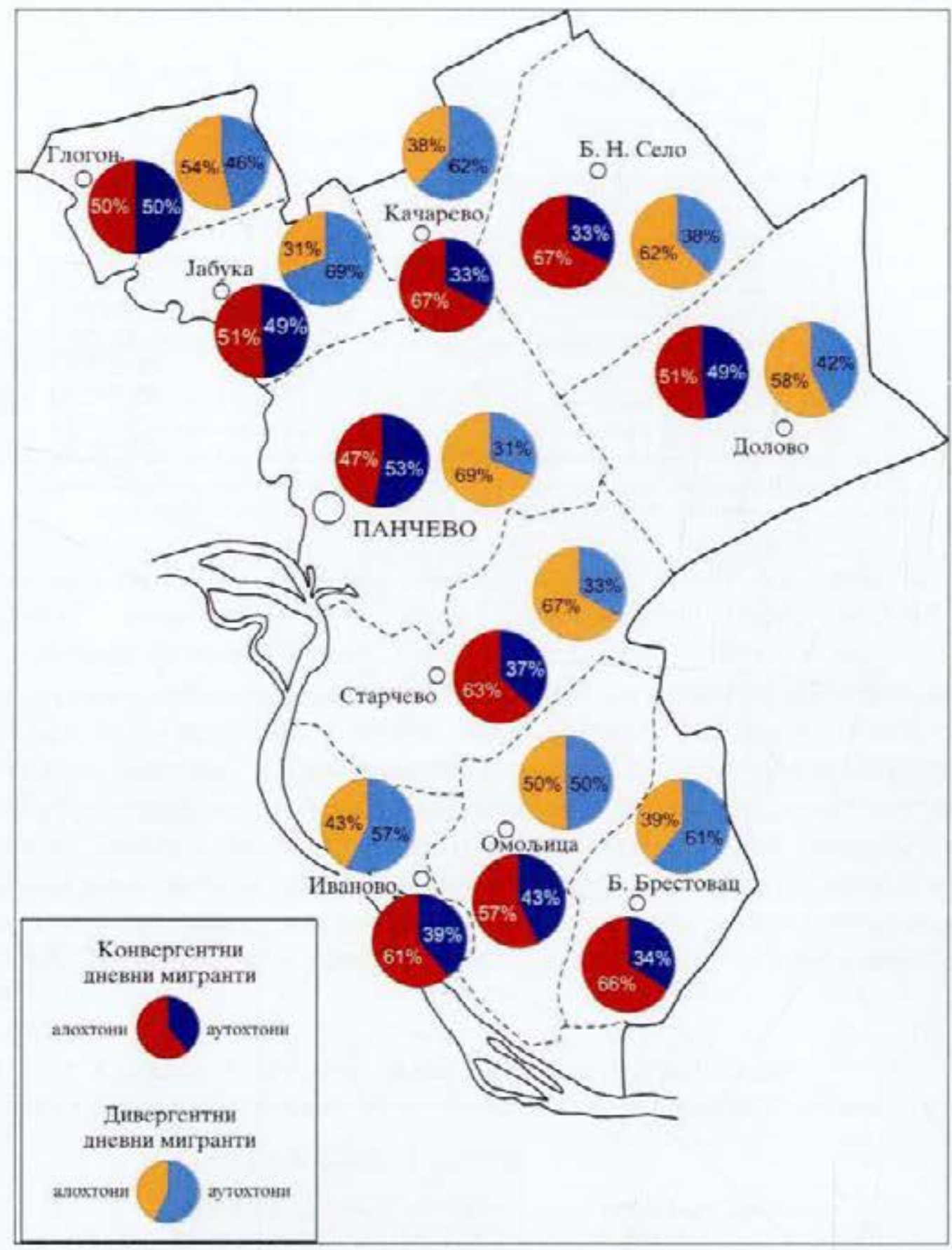

Карта 11. Дневни мигранти општине Панчево према миграционим обележјима, 2002. године Извор података: РЗС.2007 Посеб̆на обрада података.

Удео алохтоног становништва већи је у структури радника дневних миграната Панчева (дивергентни и локални дневни мигранти), у односу на укупно становништво на простору Општине. Ови подаци нису у потпуности упоредиви због разлика у старосној структури и обухвату контингената становништва. Наведени су само као транспарентан показатељ висине учешћа алохтоног становништва у дневним митращијама. Поред општинског центра, највећи удео алохтоног становништва које учествује у дневним миграцијама има приградско и Панчеву најближе насеље Старчево. Може се претпоставити да је одређени број миграната досељен у ово насеље управо како би смањио временску и просторну раздаљину потребну за путовање на посао у град Панчево. 
Табела 64. Миграшиона обележја становништва Панчева (\%) 2002. године

\begin{tabular}{|l|c|c|c|}
\hline \multirow{2}{*}{ Територија } & \multicolumn{3}{|c|}{ Алохтоно становништво (\%) } \\
\cline { 2 - 4 } & укупно & $\begin{array}{c}\text { Локални } \\
\text { дневни } \\
\text { мигранти }\end{array}$ & $\begin{array}{c}\text { Аивергентни и локални } \\
\text { дневни мигранти }\end{array}$ \\
\hline Банатски Брестовац & 42,6 & 27,7 & 33,3 \\
\hline Банатско Ново Село & 45,1 & 53,3 & 57,8 \\
\hline Глогон & 47,8 & 40,2 & 48,9 \\
\hline Долово & 40,3 & 40,2 & 46,9 \\
\hline Иваново & 37,2 & 36,5 & 39,7 \\
\hline Јабука & 42,2 & 33,2 & 32 \\
\hline Качарево & 43,7 & 34,5 & 36,2 \\
\hline Омољица & 47,3 & 42,9 & 46,7 \\
\hline Панчево & 53,1 & 72,7 & 70,8 \\
\hline Старчево & 55,4 & 63,8 & 65,3 \\
\hline Укупно & 50,1 & 44,5 & 53,2 \\
\hline
\end{tabular}

Извор података: Р3С, 2007 Посебна обрада података.

У структури активних дневних миграната који путују на посао на простор општине Панчево, преко $60 \%$ аутохтоног становништва имају токови дневних митрација са простора општина Ковин, Ковачица и Опово. Алохтони дневни мигранти преовладавају у свим токовима дневних миграција активног становништва правца Панчево - његово функционално подручје, док у токовима дневних миграната правца суседне општине - Панчево алохтоно становништво чини до 44\%. Изузетак чини размена активних дневних миграната са Београдом, где алохтони дневни мигранти чине $60-70 \%$ од укупног обима како конвергентних, тако и дивергентних дневних миграција. Ово је последица како велике привлачности Београда за мигранте, тако и структуре становништва Београда према мигращионом статусу (удео алохтоног становништва износио је $53,4 \%$ 2002. године у Београду, што је више у односу на ниво Републике Србије - $45,8 \%$,).

Графикон 12. Активни дневни мигранти општине Панчево према миграционом статусу (\%) и општини становања/рада 2002. године

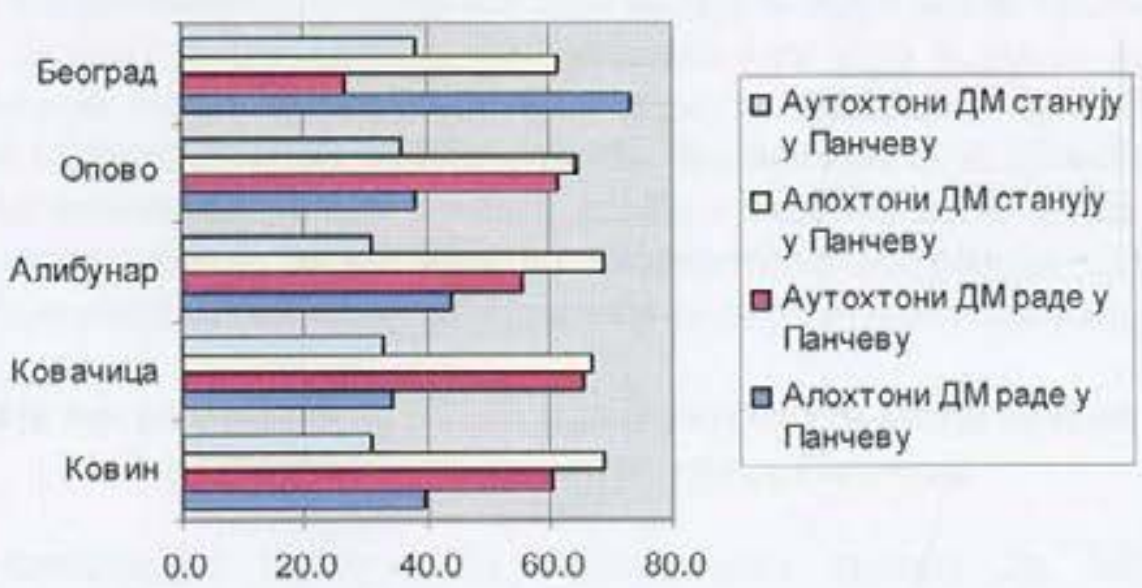

Извор података: Р3С,2007 Посебна обрада података.

у структури алохтоних дневних миграната општине Панчево највише је досељеника из Централне Србије, а затим из бивших југословенских република. Оваква структура одговара структури укупног становништва Општине према миграционим карактеристикама, где је знатан део миграната досељен из бивших југословенских република, било у процесу колонизације након Другог светског рата, било након распада бивше Југославије. Највећи удео досељених из друге општине Војводине је у 
структури дневних миграната који раде у насељу Глогоњ, и они углавном долазе са простора општине Опово.

Досељених из другог насеља панчевачке општине (локална пресељавања) знатно је више у структури алохтоних конвергентних дневних миграната, према месту одакле су се доселили, у односу на структуру алохтоних дивергентних дневних миграната, где је знатно већи удео досељених из друге републике/покрајине. Досељеника из друге општине Војводине највише је у структури локалних дневних миграната који раде у граду Панчеву.

Структура дивергентних активних дневних миграната показује да су се локално пресељавали највише дневни мигранти којима је актуелно место становања Омољица, Банатски Брестовац и Старчево - због његове близине граду Панчеву, што одговара структури укупног досељеног становништва ових насеља према пореклу. Локални мигранти претежно раде у граду Панчеву, док остали досељеници већином свакодневно путују на посао у Београд. У дневним миграционим токовима алохтоне радне снаге из насеља Банатско Ново Село и Качарево више од половине чине досељени из бивших општина СФРЈ. Половина активних дневних миграната који свакодневно путују из Банатског Брестовца и Омољице до посла у друго насеље досељена је у ова насеља у последњих пет година пре Пописа становништва из 2002. године. У Јабуци је $25 \%$, а у Старчеву $29 \%$ дневних миграната досељено у периоду 1997-2002. година. Сви ови дневни мигранти путују до Београда као центра рада.

Ако се анализира веза између дневне и дефинитивне миграције, на примеру Панчева, можемо закључити да Качарево које је једно од два насеља Општине са негативном стопом миграција у последњем десетогодишту, има највећи удео дивергентних дневних миграната у активном становништву које обавља занимање. Насупрот томе, Град Панчево има највећи удео конвергентних дневних миграната и највећy стопу усељавања. Следи да је реч о замени дневне миграције дефинитивном у оба случаја. Да би се утврдиле промене у типу везе између дневне и дефинитивне миграције за становништво појединачних насеља и простор Општине као целине потребни су подаци више сукцесивних пописа становништва који би уместо агрегатних садржали информације о конвергентним и дивергентним токовима дневних миграција становништва. За утврђивање веза између дневне и дефинитивне миграције била би значајна и анализа мотивације појединаца који радије мењају место пребивалишта или место рада. То би омогућило одређивање детерминанти када и зашто промена посла резултира променом места пребивалишта и обрнуто (Goldstein S., K.Mayer, 1964). Подаци који би садржали поред промене места пребивалишта и промену места рада омогућили би истраживање до ког степена активно становништво може мењати свој правац дневне миграције, а да не дође до дефинитивне миграције, односно до ког степена дневне миграције обезбеђују алтернативу за дефинитивну миграцију.

\section{4. Типологија насеља Панчева према критеријуму обележја дневне миграције и издвајање зона утицајне сфере Панчева}

Крајем шездесетих и почетком седамдесетих година 20. века, у нашој литератури појављују се први радови у којима аутори употребљавају коефицијенте дневне миграције као један од најважнијих критеријума за класификацију насеља, односно одређивање гравитационих подручја урбаних центара. Ако применимо типологију насеља Илића (Ilić J.,1970) према вредностима општег коефицијента дневне миграције (однос између броја становника једног насеља који раде у другом насељу и броја радника тог насеља који станују изван њега) насеља Панчева могу се класификовати као: 
- миграционо неактивна, са вредностима општег коефицијента дневне миграције мање од 10\%, (Банатски Брестовац, Долово, Иваново и Омољица),

- миграционо слабо активна, са коефицијентом дневне миграције од 10 до $25 \%$, (Банатско Ново Село, Глогоњ, Јабука, Качарево и Старчево),

- миграционо јако активна, са општим коефицијентом миграције преко $50 \%$, (Панчево).

Сва насеља општине су бимиграторна, односно и примају и дају радну снагу. Панчево и Иваново су центрипетално-центрифугална насеља, док су остала насеља центрифугално-центрипетална, тј. више дају него што примају радну снагу. Високе вредности центрипеталног коефицијента дневне миграције становништва Иванова делимично су резултат малог броја активног становништва које обавља занимање, услед рада већег броја становника у иностранству, као појаве која је специфична за ово насеље.

Табела 65. Коефицијенти дневне миграције насель Панчева 2002. године

\begin{tabular}{|l|c|c|c|}
\hline \multicolumn{1}{|c|}{ Територија } & $\begin{array}{c}\text { Центрипетални } \\
\text { коефицијент } \\
\text { миграције } \\
(\%)\end{array}$ & $\begin{array}{c}\text { Чентрифугални } \\
\text { коефицијент } \\
\text { миграције } \\
(\%)\end{array}$ & $\begin{array}{c}\text { Oпuти } \\
\text { коефицијент } \\
\text { миграчије } \\
(\%)\end{array}$ \\
\hline Банатоки Брестовац & 3,4 & 5,3 & 9 \\
\hline Банатско Ново Село & 1,8 & 7,8 & 10 \\
\hline Долово & 1,6 & 5,5 & 7 \\
\hline Глогон & 3,0 & 19,7 & 23 \\
\hline Иваново & 5,3 & 2,1 & 7 \\
\hline Јабука & 4,1 & 7,0 & 11 \\
\hline Качарево & 2,3 & 21,6 & 24 \\
\hline Омолица & 2,7 & 4,4 & 7 \\
\hline Панчево & 42,4 & 10,5 & 53 \\
\hline Старчево & 3,6 & 8,0 & 12 \\
\hline Укупно & 27,8 & 10,0 & 38 \\
\hline
\end{tabular}

Извор података: Р3С,2007 Посебна обрада података.

Структура насеља према територијалној усмерености њихових дневних миграната према Илићу (Ilić J., 1970) приказује територијални распоред и интензитет токова радне снаге на простору Панчева. Издвојене су три групе насеља:

- једнострано усмерена насеља - Јабука и Иваново са преко $90 \%$ радне снаге која путује према граду Панчеву, као и насеље Панчево са $90 \%$ токова дневне радне снаге усмерених према Београду,

- двострано усмерена насеља - Банатско Ново Село, Долово, Глогоњ и Качарево у којима $90 \%$ радне снаге путује у два правца (град Панчево и Београд) и у оба правца путује најмање $10 \%$ од укупног броја миграната,

- вишестрано усмерена насеља - Банатски Брестовац, Омољица и Старчево са више од $85 \%$ дневних миграционих токова активног становништва усмерених према Панчеву, док други по интензитету правац према Београду не чини $10 \%$ од укупног обима миграције.

Уколико прихватимо становиште да оно насеље у коме ради преко $50 \%$ радника мештана има своју функционалну самосталност (Vresk M., 1982-1983) можемо рећи да 
функционалну самосталност имају само насеља Долово, Банатско Ново Село и Панчево, који запошљавају $57 \%$, односно $61 \%$ и $89 \%$ сопственог становништва.

Биланс дневне миграције неког насеља представља разлику између конвергентних и дивергентних дневних миграната/укупан број радника који станују у насељу (Artis M., J.Romani, J.Surinach, 2000). Према вредностима биланса дневне миграције насеља општине Панчево делимо на:

- насеља са негативним вредностима дневног миграционог биланса (>-15\%): Глогоњ и Качарево,

- насеља са негативним вредностима биланса дневне миграције (-5\% до $-10 \%$ ): Банатско Ново Село,

- и насеља са негативним вредностима биланса дневне миграције (до $-5 \%$ ): Омољица, Банатски Брестовац, Долово и Старчево, и

- насеља са позитивним вредностима дневног миграционог салда: Иваново $(3,2 \%)$ и Панчево $(31,9 \%)$.

Функционална диференцијација насеља Панчева према уделу непољопривредног становништва (као показатељу степена урбанизације) и радника дневних миграната омогућава категоризацију насеља Панчева у четири групе:

- у првој групи је Панчево које, као градски и општински центар запошљава највећи део свог становништва, готово да нема пољопривредног становништва,

- у другој групи су насеља са више од 90\% непољопривредног становништва, у којима удео дневних миграната прелази две трећине активног становништва, што упућује на слабу развијеност функција. То су: Старчево, Јабука, Качарево, Омољица и Глогоњ,

- у трећој групи су насеља Иваново и Банатски Брестовац са више од 50\% дневних миграната и уделом непољопривредног становништва између 80 и $90 \%$,

- четврту групу чине Долово и Банатско Ново Село са уделом непољопривредног становништва између 70 и $80 \%$ и уделом дневних миграната од око $40 \%$ у укупном активном становништву.

Ако се као критеријум за типологију насеља узму различити облици просторне покретљивости становништва, онда можемо издвојити пет различитих група насеља Панчева према повезаности дневне и дефинитивне миграције. У првој групи налази се само град Панчево са високим вредностима коефицијента дневне миграције и позитивном просечном годишњом стопом миграционог салда од 8,3 промила. У другој зони су насеља са нешто мањим интензитетом дневне миграције и минималним досељавањима: Банатско Ново Село, Глогоњ и Старчево. Насеља са негативном стопом миграционог салда и средњим вредностима коефицијента дневне миграције су Јабука и Качарево. Насеља са средњим вредностима позитивне стопе миграционог салда и ниским вредностима коефицијента дневне миграције: Долово, Иваново. У петој зони су насеља која су слабо миграционо активна, са ниском позитивном стопом миграционог салда и ниским вредностима коефицијента дневне миграције: Банатски Брестовац, и Омољица.

Имајући у виду претходне класификације, функционално подручје (просторноутицајна сфера) Панчева, с обзиром на интензитет и последице дневне миграције радне снаге, може се поделити на три зоне. Првој функционалној зони Града Панчева (приградској или најужој зони утицаја) са удаљеношћу од градског центра до $10 \mathrm{~km}$, и са најинтензивнијом дневном миграцијом припада Старчево. Ово је насеље са 
максималним учешћем дневних миграната у активном становништву од $80 \%$ и уједно простор досељавања становништва из сеоских насеља. Као насеље најближе граду у њему су се и најбрже одвијали процеси трансформације. Промене у популацији видљиве су у економској структури становништва, која упућује да је ово изразито неграрно насеље, и повећању густине насељености и концентрације становништва. Иако је ово урбано насеље готово спојено са градом и видљиве су промене у физиономији у смислу доминације урбаних над аграрним елементима, Старчево нема значајнијих функција и његова је функција углавном резиденцијална - боравишна. Пораст броја становника Старчева праћен је малим променама у функцијској структури.

Другој или широј функционалној зони Панчева припадају готово сва насеља удаљена од градског центра до $20 \mathrm{~km}$, осим Банатског Новог Села. То су Јабука, Качарево, Глогоњ и Омољица. Изразито неграрна насеља Јабука и Качарево бележе највећи интензитет дневне миграције у овој групи (преко $70 \%$ дневних миграната у укупном активном становништву). Ово су насељьа са елементима урбаног карактера. Качарево је по административној подели градско насеље, а Јабука је била градско насеље према Попису становништва из 1971. године. И поред тога оба насеља бележе смањење броја становника, како због негативног природног прираштаја, тако и због исељавања. Друга два насеља у овој групи - Глогоњ и Омољица су неграрна насеља, са мање интензивном дневном миграцијом и уделом дневних миграната у активном становништву од $65 \%$ односно $62 \%$. Промене настале под утицајем дневних миграција углавном су популационе (промене у структури активног становништва и уделу домаһинстава са пољопривредним газдинством). Када је реч о физиономским елементима доминирају аграрни над урбаним елементима.

У ширем функционалном залеђу Панчева, удаљена од 20-30 km, су насеља Банатски Брестовац, Иваново и Долово. Њихова функционална повезаност са градом је најмања. Удео дневних миграната у активном становништву ових насеља је од $39 \%$ до $52 \%$, док према економској структури становништва припадају мешовитом типу насеља. Последице дневних миграција долазе до изражаја само у економској структури становништва. Трећој функционалној зони, иако географски ближе, према свим осталим карактеристикама припада и насеље Банатско Ново Село.

Зону најинтензивнијег утицаја града Панчева, као центра рада, са преко $70 \%$ запослених који свакодневно путују у град на посао чине насеља Јабука и Старчево. Зону јаког утицаја, из које у Град као центар рада дневно мигрира $50-70 \%$ радника чини насеље Омољица. Остала насеља припадају зони средњег утицаја из које у центар рада дневно мигрира $30-50 \%$ запослених. ${ }^{20}$ Из насельа суседних општина у град Панчево као центар рада свакодневно путује мање од $30 \%$ запослених. Највеһи удео радника који учествују у дневним миграцијама према Панчеву имају насеља Мраморак (21\%), и Баваниште $(18,6 \%)$.

\section{5. Утицај функционалног подручја Београда на правце и структуру миграционих токова дневног урбаног система Панчева}

За обим и правце дневних миграција становништва веома је важна како хоризонтална - просторна тако и вертикална - функцијска организација мреже насеља. На простору општине Панчево изражен је велики функционални утицај Београда, који се одражава на одвијање процеса дневних миграција становништва. Близина Београда и његов ранг у функционалној структури урбаних центара Србије условили су велики

\footnotetext{
${ }^{20}$ Према Д.Тошић,1999.
} 
обим дивергентних дневних миграционих токова становништва Панчева, који произилази из веһег функционалног капацитета Београда, ${ }^{21}$ односно нижег функционално-хијерархијског ранга Панчева у односу на Београд. Уколико се посматра структура дневних миграционих токова на релацији Панчево-Београд однос активних дневних миграната и ученика/студената је изједначен. То указује на привлачност како економских, тако и не-економских функција Београда за становништво Панчева. После Београда центри мање атрактивне снаге су суседне општине Алибунар и Ковачица, и њихова привлачност далеко је мања од привлачности главног града.

Поједина централна насеља различитог функционално-хијерархијског ранга испољавају се у геопростору као иницијатори, носиоци и регулатори развијености различитих видова дневног кретања становништва, а самим тим и као кохезиони фактори просторног обједињавања и функционалног повезивања групе насеља (Stamenković S.,1996). Београд је водећи носилац општеразвојних токова на нивоу државе са израженом економском и културно-образовном привлачношћу и низом функција по којима је доминантан (високошколска, високосудска, административноуправна на државном нивоу), а што има за ефекат да је Београд простор суперконцентрације становништва и активности. Висок степен функционалне сложености дефинише Метрополитен Београда, као подручје повезано одређеном серијом функционалних веза на свакодневној основи (чине га 16 општина Града Београда, Панчево, Смедерево, Смедеревска Паланка, Рума и Стара Пазова) (Урбанистички Завод Београда, 2002). Правци најинтензивнијих токова дневних миграција радне снаге са простора општине Панчево јесу управо између градова Панчева и Београда као центара запослења. Обимнији токови дневних миграција усмерени су из Панчева, као регионалног и првенствено индустријског центра, према Београду као популационо већем центру са развијеним како привредним, тако и непривредним функцијама и бројним установама са различитим радним местима. Ове чињенице иду у прилог тези о слабој повезаности између простора сличних по друштвено-економској структури. Конкурентност градова Панчева и Београда у погледу функција и њихова непосредна близина, утиче на појаву преклапања њиховог функционалног подручја, која се огледа у постојању двострано миграционо усмерених насеља (Банатско Ново Село, Глогоњ, Долово и Качарево).

С обзиром на донекле периферан територијални положај Панчева у склопу Баната и Војводине, који је у складу са малим бројем градова у Банату и њиховим неравномерним размештајем, честа су запажања да“своју шансу за развој Панчево треба да тражи у везној - посредничкој улози са суседним геопросторним целинама" (Вељковић А., Јовановић Р., Тошић Б., 1995). Београдска агломерација као сложен функционално урбани систем насеља удаљена је $21 \mathrm{~km}$ од Панчева, са којим је добро саобраһајно повезана редовним и честим аутобуским линијама као и линијама Беовоза. Као највећем националном урбаном систему - Београду гравитира 7.818 дневних миграната, или $92 \%$ целокупне популације дневних миграната општине Панчево који путују ка другим општинама. У структури дневних миграната који гравитирају Београду однос ученика/студената и радника је $50,3 \%$ на према $49,7 \%$. У правцу Панчева из Београда путује 1.590 дневних миграната, од чега $95,2 \%$ чини активно становништво. Највећи број дневних миграната путује са простора суседне општине Палилула (341), док су друге београдске општине које Панчеву дају више од 100 дневних миграната Нови Београд, Звездара, Вождовац, Земун и Чукарица. Велики број дневних миграната са простора општине Панчево непознате београдске општине рада/школовања (чак 5.520) онемогућава сазнања о интензитету дневних миграционих

\footnotetext{
${ }^{21}$ O појму функционалног капацитета детаљније видети у раду J. Илића (llić J., 1970).
} 
токова усмерених ка појединачним београдским општинама. На основу података о познатим дестинацијама дневних миграната уочава се да је на првом месту општина Палилула (475 дневних миграната). Можемо закључити да је ово београдска општина са којом суседно Панчево има највећу размену дневних миграната (претежно радне снаге). Остале београдске општине које примају већи број дневних миграната са простора општине Панчево су централне општине Стари Град и Савски Венац, у којима се налази велики број високошколских установа и које су седиште разних установа везаних за непривредне делатности.

Бодовање радника који долазе из Београда према просечној квалификацији радника ${ }^{22}$ потврдило је да су дневне миграције радника из већих градова у околину значајне, упркос томе што обухватају мали број радника, јер у њима већински учествују квалификованији радници и стручњаци. Израчунавање индекса сличности ${ }^{23}$ за поређење образовног нивоа становништва које долази и одлази са простора општине Панчево показало је највеће разлике за радну снагу која иде у правцу Београд-Панчево (индекс сличности 35,0 односно индекс различитости 65,0 ). Вредност индекса различитости показује проценат у популацији дневних миграната који иду у смеру Београда који би се морао прерасподелити између образовних група да би образовна структура била иста као структура радне снаге која иде из смера Београда.

Проширене дневне миграције, или дневне миграције из околних подручја у веће центре сматрају се за најважнији појединачни механизам где се импулси раста преносе из великих регионалних центара раста у околне градове и сеоска подручја. Доказано је да мали градови у близини већих урбаних центара имају значајну улогу у смањењу проширене дневне миграције на дистанцама између 25 и $35 \mathrm{~km}$ (Taaffe E., H.Gauthier, T.Maraffa, 1980). Зато је потребно остваривање још јачих просторно функционалних веза Панчева са Београдом и већег степена њихове интегрисаности, што "не би требало да доведе до слабљења функционалног утицаја Панчева у Јужном Банату, већ напротив да га ојача" (Урбанистички Завод Београда, 2002).

\section{6. Последице дневних миграција становништва на трансформацију геопростора општине Панчево}

Развој дневних миграција утицао је на трансформацију геопростора општине Панчево узрокујући физиономске, популационе, економске, психо-социјалне и културне последице. Последице дневних миграција најизраженије су у насељима са највећим бројем дневних миграната. То су поред општинског центра, Старчево и Јабука.

Највеће физиономске промене на простору општине Панчево настале под утицајем дневних миграција становништва могу се запазити у приградским насељима, нарочито у Старчеву, чије су промене у физиономији настале услед непосредне близине града Панчева и припадности његовом функционалном подручју. Уочљиве су и промене везане за саобраћајнице (унапређење њиховог квалитета односно модернизацију, као и повећање обима путничког промета).

Популационе последице дневних миграција становништва видљиве су у променама основних компоненти демографског развоја, променама у структури становништва и домаћинстава и повећаном броју становника и густини насељености у приградским насељима. Једна од популационих последица дневних миграција становништва на простору општине Панчево јесте умањен број становника Општине за 4.067 становника током дана, колико износи разлика између суме становништва које

\footnotetext{
${ }_{22}^{22}$ Види Žagar M., 1959.

${ }^{23}$ Види Stone L, 1971.
} 
станује и ради/ школује се на простору Општине и становништва које свакодневно долази да ради/школује се у Панчеву, и сталног становништва Општине које из Панчева свакодневно одлази да ради/школује се на простору неке друге општине. У периоду 1948-2002. година највећи забележен популациони пораст на простору Oпштине, поред општинског центра, имала су приградска насеља делом и услед деловања дневних миграција. Интензиван популациони пораст одвијао се у Јабуци и Качареву (повеһање популације за 50\%) а нарочито у Старчеву (повећање популације за више од сто одсто). Качарево је пораст броја становника остваривало до 1981. године, а највише у периоду 1953-1961. година, од када се број становника Качарева константно смањује. Док је шездесетих и седамдесетих година прошлог века стопа наталитета била већа у сеоским насељим,а компоненте популационих промена показују да су вредности стопе наталитета на нивоу Општине временом прилично уједначене. До тога је дошло и услед мешања становништва из различитих средина путем дневних миграција. Смањен је и број вишепородичних домаћинстава и просечна величина домаћинства у овим насељима. Дневне миграције становништва рефлектују се такође и на структуру становништва по секторима привредне делатности. Популациони ефекти дневне миграције манифестују се у смањењу обима активног пољопривредног становништва. С друге стране дневне миграције утичу на повећање општег нивоа образовања и промене у професионалној структури становништва у насељу становања дневних миграната, што доприноси јачању интензитета дневне миграције, па и преласку дневне у дефинитивну миграцију.

Економске последице дневних миграција становништва Панчева произилазе из чињенице да доходак дневних миграната остварен у другом насељу, мења дистрибуцију локалних прихода и повећава куповну моћ и структуру потрошње становништва насеља становања. Део ових прихода користи се за школовање деце и њихово даље образовање. Процес дневних миграција има утицаја и на промене функционалних обележја насеља и намену површина. Свега 17\% дневних миграната који станују на простору Општине Панчево а привређују у другом насељу поседује пољопривредно газдинство. Најмањи удео дневних миграната са пољопривредним газдинством је у приградским насељима Старчево и Качарево (РЗС,2007 Посебна обрада података). Приградска насеља Панчева, Јабука, Старчево и Качарево, услед близине и функционалног утицаја Панчева још 1971. године имала су мањи удео пољопривредног становништва у укупном од осталих насеља Општине.

Позитивна последица процеса дневне миграције становништва Панчева су промене у начину живота чији су носиоци како панчевачки радници, тако и ученици/студенти који свакодневно путују у друго насеље до школе/посла. Промене у нивоу образованости становништва, способности, искуство и квалификованост које дневни мигранти стичу позитивно се одражавају на развој њиховог насеља становања на простору општине Панчево.

Као негативна последица дневних миграција, с обзиром на селективност која одликује сваки миграциони процес као и прелазак дела дневне миграције у дефинитивну, могло би доћи до евентуалног губитка квалификованог и висококвалификованог кадра или недостатка одређених кадрова на простору Општине, што би се негативно одразило на свеукупан локални развој.

\section{7. Могући правци развоја функционалног подручја Панчева и њему коресподентних дневних урбаних система}

Када је реч о трајању процеса дневне миграције (перспективи) било је мишљења неких аутора да је овај феномен пролазног карактера и да је повезан са одређеном 
фазом индустријализације и урбанизације док су други аутори тврдили да је свакодневно путовање до посла стабилног карактера (Roca O.,1986). Време је међутим показало да дневне миграције нису пролазан и привремени феномен везан за одређену фазу развоја друштва већ опстају, као посебан облик просторне покретљивости становништва, поспешене развојем саобраћајне мреже и саобраћајних средстава. Мењају се само њихови правци и структура токова у зависности од промене услова у којима се одвијају или личних аспирација дневних миграната. Дневне миграције у Србији, интензивне шездесетих и седамдесетих година 20. века - управо у време снажне индустријализације и урбанизације, део су свакодневнице великог броја радника и ученика/студената и данас, и бележе сталан пораст обима нарочито у великим градовима и индустријским центрима.

Услови одвијања дневних миграција су променљиви. С обзиром да се одвијају под утицајем демографског и друштвено-економског развоја простора становања и рада дневне миграције становништва подлежу променама које су резултат развојних процеса у овим срединама. Динамична природа дневних миграција одражава се у трансформацијама токова дневних миграција (обим и правци), али и структуре дневних миграната током времена. Промена услова у којима се дневне миграције одвијају (саобраћајна повезаност између места становања и места рада) или промена неке од детерминанти дневних миграција, резултира смањењем или повећањем броја дневних миграната, променом праваца и структуре токова дневних миграција. Промена реда вожње или нпр. повећање цене превоза (када трошкови путовања пређу новчани износ који дневни мигрант може себи да приушти) могу да доведу до напуштања статуса дневног мигранта од стране одређеног броја људи.

3бог трошкова свакодневног путовања али и бројних других последица како за радника и његову породицу, тако и за послодавца често се у литератури истиче неодрживост дневних миграција на дуже време. У том смислу део дневне миграције нужно прелази у (замени се за) дефинитивну миграцију. Ова замена једног облика миграције за други зависи од бројних фактора и као таква све више постаје предмет научних проучавања. Највећи број сељака-радника у бившој Југославији намеравао је задржати статус двојне активности, а за $21,9 \%$ дневне миграције су служиле као прелазна фаза за напуштање пољопривредне активности. Ови сељаци су махом били образованији и у више урбанизованим насељима (Roca O.,1986). Истраживања потенцијалне гравитационе привлачности у Алексинцу, Брусу и Врању су показала да се од укупног броја дневних миграната између $27,3 \%$ и $33,7 \%$ дневних миграната изјаснило да hе домицил током извесног времена заменити насељем школовања/рада. Већина испитаника који су намеравали да се селе планирала је да реши стамбено питање у новом месту становања добијањем стана или градњом куће, док је модалитет изнајмљивања стана чинио веһину само у случају лица која нису у браку. Запажен је значај фактора животног циклуса за време замене дневне миграције дефинитивном. (Стаменковић С., 1989; Стаменковић С. и др.,1995). Напред наведени подаци указују да најчешће око једне трећине дневних миграната има намеру да дневну миграцију замени дефинитивном. Ипак остаје питање колико се тих намера заиста и реализује. Имајући у виду цене некретнина и веома мали број предузећа која у данашње време додељују станове радницима дневне миграције ће наставити да буду средство прилагођавања различитим просторним могућностима за запослење, нарочито за лица која су у браку. Уколико би се за дефинитивно пресельее одлучила једна трећина дневних миграната који раде у граду Панчеву, број становника општинског центра у наредном периоду увеһао би се за 3.857 становника. Ако се узму у обзир само лица која нису у браку, за које је према резултатима истраживања С. Стаменковића потребно испуњење мање 
предуслова да би дошло до замене дневне дефинитивном миграцијом, град Панчево добио би у наредном периоду 1.615 нових становника.

Даљи развој дневних миграција Панчева одвијаће се у складу са трансформацијама у обиму, структури и размештају расположивог кадровског потенцијала, развојем и захтевима привредних и ванпривредних делатности и реструктуирањем привреде, и развојем саобраћајне инфраструктуре. С обзиром на тренд негативног природног прираштаја на простору општине Панчево и суседних општина, одакле гравитира највећи број дневних миграната Панчева, за очекивати је да се обим дневних миграција (како радних, тако и ученичких/студентских) постепено смањује како на овом простору тако и у целој земљи, због смањења контингената овог становништва и промена у старосној структури становништва које he се негативно одразити на тржиште рада. Након смањења обима радне снаге у сеоским насељима Панчева и у приградским насељима и општинском центру доһи he до постепеног смањења обима радно способног становништва, а тиме и активног становништва које обавља занимање, што ће се одразити на обим и токове дневних миграција на простору Општине. И поред евентуалног смањења у обиму дневних миграција град Панчево и даље hе бити примарни центар дневне миграције за раднике сеоских насеља општине Панчево уз очекивано повећање удела међуопштинских дневних миграција.

Поред демографског развоја, као основе за промене у обиму токова радне снаге, на даљи развој дневних миграција на простору општине Панчево утицаће и бројни друштвено-економски фактори. Привредне реформе и потражња за радном снагом највећих предузеһа на простору Општине (азотаре и нафтно-хемијског индустријског комплекса) имаће значајан ефекат на будући обим, правце и структуру токова радне снаге. На дневне токове радне снаге деловаће и динамика оснивања малих и средњих предузећа на простору Општине чији һе значај бити нарочито велики за сеоска насеља. Oпште тенденције повећања броја запослених у услужним делатностима негативно ће се одразити на токове дневних миграција активног становништва ове првенствено индустријске општине. Смањење броја послова у производњи и пораст броја послова у услужним делатностима учиниће доминантнијим токове дневних миграција ка Београду, као центру веһег ранга у функционалној хијерархији насеља и највећем метрополитенском подручју Србије са снажним поларизационим утицајем. За очекивати је да he се у наредном периоду промене у структурним карактеристикама радника-дневних миграната Панчева одвијати под утицајем повећања броја високообразованих, пораста запослености жена и сагласно томе повећања броја домаћинстава са два радника, појаве нових занимања и других процеса који се већ увелико одвијају у развијенијим земљама. Формирање токова дневних миграција биће такође под утицајем измењених услова рада који подразумевају померање старосне границе за одлазак у пензију - продужетак радног века и промене радног времена (917h). На перспективе даљег развоја дневних миграција Панчева одразиће се и пораст флексибилности тржишта рада, у условима развоја информационих технологија, и побољшање саобраћајне инфраструктуре, што ће резултирати све разноврснијим путањама дневних миграција активног становништва Панчева.

Демографска и физиономска еволуција града Панчева и насеља која му гравитирају као и трансформација постојећих и стварање нових функција такође су неки од фактора који hе утицати на обим, структуру и просторну усмереност будуһих токова дневних миграција становништва на овом простору. У складу са тим променама мењаһе се и просторно-функционални односи и везе у ближем и даљем окружењу, односно последично и облик и величина функционалног подручја Панчева и функционалних зона. Будући развој и правци дневних миграција становништва Панчева зависиће и од подизања квалитативног ниова животне средине. 
Дневни урбани систем Панчева мењаһе се у складу са променама хијерархијске, просторне и временске димензије регионалних и националних урбаних система. У Панчеву се уопште може очекивати смањење обима локалних дневних миграција, с обзиром на константно смањење оквира за радну снагу у сеоским насељима, који би заменили раднике који одлазе у пензију или се одлуче за дефинитивну миграцију. С друге стране интензитет токова активног становништва према Београду ће се повећати, нарочито са даљим унапређивањем саобраһајних веза и развојем услужних делатности, што he допринети да се ови градски центри још више просторно и функционално интегришу. 


\section{V ТЕСТИРАЮЕ УТИЦАЈА ДЕМОГРАФСКИХ И \\ СОЦИО-ЕКОНОМСКИХ ВАРИЈАБЛИ \\ НА ПРОСЕЧНУ ДУЖИНУ ПУТОВАЊА ДНЕВНОГ МИГРАНТА У ЈЕДНОМ СМЕРУ}

Бројна истраживања показују да су просторна раздаљина (удаљеност) између места становања и места рада, време проведено у путу, врста превозног средства и трошкови путовања у зависности од демографских и социоекономских карактеристика дневних миграната. Посебном обрадом података Пописа становништва из 2002. године извршено је унакрсно табелирање података о мигрантима дневног урбаног система Панчева према месту становања и месту рада, а у складу са одабраним показатељима, како би се дошло до сазнања које демографске и социоекономске карактеристике активног становништва утичу на разлике у просторној раздаљини и смеру дневних миграција.

Помоћу софтверског програма SAS коришћен је $t$-mест за испитивање статистичке значајности разлика у просторној раздаљини дневне миграције према полу. Увођењем категоријских варијабли за дужину пута тестирана је Chi квадрат тестом једнакост расподеле фреквенција по класама дужине пута, по полу и брачном стању, а затим је за поједине подскупове примењен $\mathrm{t}-$ тест.

Циљ је утврђивање статистички значајних варијабли везаних за популациону структуру а које су значајне за разлике у путањама дневних миграција. Приликом статистичке анализе тежило се проучавању са аспекта демографије. Нагласак је на демографским факторима за које је се сматра да утичу на процес дневне миграције, како би се открило на који начин ови фактори делују на дневне мигранте на конкретном примеру дневног урбаног система Панчева. Нарочито је стављен акценат на:

- испитивање утицаја брачног статуса и породичне структуре на дневну просторну покретљивост економски активних жена,

- евалуацију до ког обима варијација путања дневних миграција жена зависи од ових фактора.

Добијени резултати се доводе у везу са досадашњим сазнањима о процесу дневних миграција становништва како у домаһој тако и у иностраној литератури, са циљем провере неких стандардних хипотеза везаних за дневне мигранте (као што су нпр. краће путовање жена и утицај брачног статуса и породичне структуре на раздаљину и правце дневне миграције жена - тзв. хипотеза одговорности у домаћинству). Утврђивање позитивних и негативних фактора утицаја на миграциони процес основа је за доношење закључака о правцима будућег развоја дневних миграција на простору Панчева и шире.

\section{1. Просечна просторна дистанца конвергентних и дивергентних миграната дневног урбаног система Панчева}

Број фактора који делују на процес дневне миграције је велики па је самим тим и испитивање односа и веза између њих знатно сложено. Приликом утврђивања да ли и до ког обима правци дневних миграција и просторна раздаљина коју дневни мигрант пређе у једном смеру зависе од демографских и социоекономских обележја појединца и његовог домаћинства пошло се од хипотезе да постоји интеракција између ових фактора. 
Као основни скуп за истраживање узета је популација активних миграната дневног урбаног система Панчева без лица која су имала неке непознате одреднице битне за анализу (13.628 лица). С обзиром да је реч о географској раздвојености места рада и места становања коришћена је анализа просторне раздаљине дневне миграције (просечан број пређених километара у једном смеру). На одлуку да се користи просторна раздаљина дневне миграције такође су утицала и сазнања других аутора ${ }^{24}$ o јаснијим разликама у дневној миграцији према полу, када се посматра просторна раздаљина дневне миграције у односу на време путовања. За потребе ове анализе сваком појединачном запису у асеss бази додељена је нова варијабла дужина пута којој је дата вредност просторне дистанце дневне миграције у једном смеру за дневног миграната. Ове вредности су израчунате на основу најкраћих раздаљина између насеља становања и насеља рада, а према постојећој путној мрежи. Просторна граница дефинисана је путовањем које је мање или једнако од $60 \mathrm{~km}$ у једном правцу.

Приликом анализе варијација просторне раздаљине дневне миграције посматране су две групе испитаника: 1 . они који свакодневно долазе да раде у Панчеву са простора изван Општине и 2. они који свакодневно одлазе на посао ван простора општине Панчево. Искључени су из анализе дневни мигранти за које су непознате одређене варијабле. Просечна раздаљина дневне миграције за конвергентне дневне мигранте износи $18,3 \mathrm{~km}$ за мушкарце и $17,2 \mathrm{~km}$ за жене, а за дивергентне дневне мигранте $28,7 \mathrm{~km}$ за мушкарце и $26,5 \mathrm{~km}$ за жене.

Разлике у просечној раздаљини путовања између мушкараца и жена у браку највидљивије су код нижих нивоа образовања. Утицај образовања на просечну просторну раздаљину дневне миграције је приметан, мада више када је реч о женској популацији. Можемо закључити да образовање генерално повећава просторне дистанце активних жена које учествују у дневној миграцији.

Табела 66. Разлике у просечној просторној раздаљини дневне миграције $(\mathrm{km})$ према полу, образовању и брачном статусу

\begin{tabular}{|l|c|c|c|c|c|c|}
\hline \multirow{2}{*}{ Образовање и брачно стање } & \multicolumn{2}{|c|}{ Раде } & \multicolumn{2}{c|}{ Стануі } & \multicolumn{2}{c|}{ Укупно } \\
\cline { 2 - 7 } & Мушкарци & Жене & Мушкарци & Жене & Мушкарци & Жене \\
\hline Незавршена основна школа & & & & & & \\
\hline Самци & 20,2 & 21,0 & 39,0 & 22,0 & 29,0 & 21,5 \\
\hline У браку & 19,1 & 15,7 & 37,0 & 22,0 & 28,0 & 18,8 \\
\hline Основна школа & & & & & & \\
\hline Самци & 19,6 & 17,5 & 29,9 & 27,6 & 24,7 & 22,5 \\
\hline У браку & 17,5 & 14,8 & 32,8 & 27,8 & 25,0 & 21,3 \\
\hline Средьа школа & & & & & & \\
\hline Самци & 18,1 & 17,7 & 27,7 & 27,9 & 22,9 & 22,8 \\
\hline У браку & 17,7 & 17,0 & 29,1 & 26,7 & 23,4 & 21,8 \\
\hline Виша школа & & & & & & \\
\hline Самци & 23,1 & 18,3 & 20,7 & 27,4 & 21,9 & 22,8 \\
\hline У браку & 20,4 & 17,6 & 26,6 & 25,5 & 23,5 & 21,5 \\
\hline Висока школа & & & & & & \\
\hline Самци & 22,5 & 20,9 & 24,7 & 24,4 & 23,6 & 22,6 \\
\hline У браку & 23,1 & 21,4 & 26,3 & 26,1 & 24,7 & 23,7 \\
\hline
\end{tabular}

Извор података: Р3С, 2007 Посебна обрада података.

Године старости немају већег утицаја на просечну дистанцу путовања активног дневног митранта, а што је нарочито видљиво код удатих жена. Најдаље путују најстарији дневни мигранти, мада овај податак треба узети са резервом због малог броја дневних миграната у категорији становништва преко шездесет година старости.

\footnotetext{
${ }^{24}$ Види Hanson, Johnston, 1985.
} 
Табела 67. Разлике у просечној просторној раздаљини дневне миграције $(\mathrm{km})$ према полу, старосној групи и брачном статусу

\begin{tabular}{|c|c|c|c|c|c|c|}
\hline \multirow{2}{*}{ Старост и брачно стање } & \multicolumn{2}{|c|}{ Page } & \multicolumn{2}{|c|}{ Стануру } & \multicolumn{2}{|c|}{ Укупно } \\
\hline & Мушкарци & Жене & Мушкарци & Жене & Мушкарци & Жене \\
\hline \multicolumn{7}{|l|}{ до 19 година } \\
\hline Самии & 19,4 & 17,1 & 33,7 & 26,6 & 26,5 & 21,8 \\
\hline У 6 paky & $\cdot$ & $\cdot$ & $\cdot$ & $\cdot$ & $\cdot$ & $\cdot$ \\
\hline \multicolumn{7}{|l|}{ 20-39 година } \\
\hline Самии & 18,5 & 18,3 & 27,7 & 27,3 & 23,1 & 22,8 \\
\hline У браку & 18,5 & 17,2 & 28,5 & 25,9 & 23,5 & 21,5 \\
\hline \multicolumn{7}{|l|}{ 40-59 година } \\
\hline Самии & 20,5 & 18,8 & 24,4 & 26,2 & 22,4 & 22,5 \\
\hline у браку & 18,1 & 16,9 & 29,6 & 26,9 & 23,8 & 21,9 \\
\hline \multicolumn{7}{|l|}{$60+$ година } \\
\hline Самии & 16,0 & 13,0 & - & 22,0 & 16,0 & 25,4 \\
\hline У браку & 19,4 & 20,5 & 31,0 & 39,0 & 25,1 & 30,6 \\
\hline
\end{tabular}

Извор података: Р3С, 2007 Посебна обрада података.

Жене путују краће од мушкараца без обзира на сектор делатности рада. Раднице које иду на посао изван Панчева, независно од сектора делатности у коме су запослене, путују просечно дуже од жена које долазе на посао у Панчево са простора других општина.

Табела 68. Разлике у просечној просторној раздаљини дневне миграције $(\mathrm{km})$ према полу и сектору делатности рада

\begin{tabular}{|l|c|c|c|c|c|c|}
\hline \multirow{2}{*}{ Сектор делатности } & \multicolumn{2}{|c|}{ Раде } & \multicolumn{2}{c|}{ Стануіу } & \multicolumn{2}{c|}{ Укупно } \\
\cline { 2 - 7 } & Мушкарци & Жене & Мүшкарци & Жене & Мушкарци & Жене \\
\hline Примарни & 18,7 & 17,3 & 28,9 & 30,1 & 23,8 & 23,7 \\
\hline Секунцарни & 17,3 & 16,5 & 29,8 & 25,7 & 23,5 & 21,1 \\
\hline Терцијарни & 19,3 & 17,5 & 28,2 & 25,2 & 23,7 & 21,3 \\
\hline Квартарни & 21,9 & 17,6 & 27,1 & 27,6 & 24,5 & 22,6 \\
\hline
\end{tabular}

Извор података: Р3С, 2007 Посебна обрала података.

Када се посматра ефекат миграционе историје на просторну раздаљину дневне миграције евидентно је да у појединим категоријама становништва алохтони дневни мигранти путују даље до посла у односу на аутохтоне. Чињеница да алохтони радницижене путују просторно даље од аутохтоних указује да нека пресељења нису проузрокована тежњом радника да буду ближе месту рада већ другим разлозима (нпр. удаја).

Табела 69. Разлике у просечној просторној раздаљини дневне миграције $(\mathrm{km})$ према полу и миграционом статусу

\begin{tabular}{|l|c|c|c|c|c|c|}
\hline \multirow{2}{*}{ Миграциони статус } & \multicolumn{2}{|c|}{ Раде } & \multicolumn{2}{c|}{ Стануلу } & \multicolumn{2}{c|}{ Укупно } \\
\cline { 2 - 7 } & Мушкарци & Жене & Мушкарци & Жене & Мушкарци & Жене \\
\hline Аутохтони & 18,4 & 16,9 & 29,9 & 28,4 & 24,1 & 22,6 \\
\hline Алохтони & 18,3 & 17,5 & 27,9 & 25,5 & 23,1 & 21,5 \\
\hline
\end{tabular}

Извор података: Р3С, 2007 Поссбна обрада података.

Из напред наведених резултата се види да је просторна раздаљина дневне миграције жена у урбаном систему Панчева по правилу мања у односу на мушкарце. У формирању миграционих процеса поред бројних других фактора веома је значајна и улога домаһинства и породице као биолошке и економске асоцијације становништва. Стога је приликом разматрања дневних миграционих токова у урбаном систему Панчева посматрано и домаһ̆инство дневног мигранта, које већином чини породица у ужем смислу (само родитељи и деца). Истраживању дневних миграција становништва Панчева у форми која је представљена допринела су сазнања о повећаној економској 
активности жена, и актуелности и предности посматрања миграција на нивоу домаћинства.

Разлике у просторној раздаљини путовања према полу остају изражене и када се посматра тип домаћинства (једнопородично/вишепородично), као и у односу на групе испитаника (конвергентни/дивергентни). Просечна раздаљина путовања дневног мигранта према типовима њихових породица показује да је у случају када је један супружник дневни мигрант просторна дистанца дневне миграције радника већа него ако су оба супружника дневни мигранти.

Запажено је да број деце у породици свесно утиче на одлуку жене о запослењу, те да стопа запослености жена опада са присуством и повећањем броја деце у породици. Подаци статистике Комитета за једнакост полова Парламентарне скупштине Савета Европе показују да свака трећа жена у Европској Унији ради скраһено радно време, пре свега због бриге о деци, док свега четири одсто мушкараца ради скраћено радно време (Pissarides C. et al., 2000). Због утицаја економске активности жена на породични живот у ово истраживање укључено и испитивање утицаја присуства детета на просечну раздаљину путовања чланова породице, у зависности од тога да ли су оба или један супружник дневни мигранти. Показало се да су само у породицама које имају више од двоје деце предшколског узраста деца значајан фактор утицаја на дистанцу дневне миграције независно од смера путовања (конвергентни и дивергентни токови). Удео ових породица у укупном броју породица је свега $0,5 \%$.

Када је реч о типу домаћинства дневних миграната, уколико у домаћинству живи још неко ко није члан нуклеарне породице просечна раздаљина дневне миграције запослених жена се смањује (просек за жене 19,6 km). Тако супротно сазнањима других аутора да проширено домаћинство олакшава дневну миграцију жена (Lee B. S., J. Mc Donald, 2003) закључујемо да је проширено домаћинство у практичним условима заправо отежавајући фактор у случају дневне миграције жена Панчева, односно да жене у вишепородичним домаћинствима путују просторно краће. Доказан мањи територијални домет дневне миграције жена у вишепородичним домаћинствима, када ce посматрају дневне миграције активног становништва на нивоу Општине, у сагласности је са добијеним резултатима о мањем учешһу жена у дневној миграцији уколико у домаћинству дневног мигранта живи још неки члан осим нуклеарне породице (види поглавље породице дневних миграната).

Табела 70. Разлике у просечној просторној раздаљини дневне миграције $(\mathrm{km})$ према породичним карактеристикама

\begin{tabular}{|l|c|c|}
\hline Породичне карактеристике & Мушкарии & Жене \\
\hline Супружник ради & & \\
\hline Аа & 20,3 & 19,5 \\
\hline не & 20,2 & 19,3 \\
\hline Супруноик путује & 18,8 & \\
\hline да & 23,1 & 18,8 \\
\hline не & & \\
\hline Вишепородично домаһинство & 19,9 & 18,9 \\
\hline да & 20,4 & 19,7 \\
\hline не & & \\
\hline Деца Ао седам година & 20,4 & 19,5 \\
\hline Не & 20,6 & 19,6 \\
\hline Једно & 23,5 & 23,3 \\
\hline Двоје & 20,0 & 19,1 \\
\hline Више од Авоје
\end{tabular}

Извор података: Р3С, 2007 Посебна обрада података. 
Резултати анализе ефеката демографских, социеоекономских и породичних карактеристика на просторну раздаљину дневне миграције потврђују сазнања из међународне литературе о различитом деловању ових фактора за мушкарце и жене, тј. о генерално краћем просечном путовању жена. Жене већином путују на краћим раздаљинама од мушкараца који су истог образовања, раде у истом сектору делатности, имају исте породичне карактеристике и путују у истом смеру. Изузетак су жене које нису у браку, имају завршену средњу или вишу школу и путују изван Панчева на посао. У обе групе испитаника у домаћинствима где обоје супружника ради жене путују на краћим раздаљинама од мушкараца, што потврђује хипотезу о већој одговорности жена у домаћинству. Жене које нису у браку путују просечно готово исто као и мушкарци који нису у браку (27,0 km на према $27,5 \mathrm{~km}$ за оне који раде у Панчеву), али зато жене које су у браку путују просечно краће од мушкараца који су у браку за 2 km, односно $4,5 \mathrm{~km}$ краһе од мушкараца у домаћинствима са једним радником и $4,4 \mathrm{~km} \mathrm{y}$ домаһинствима где оба супружника раде. Жене чији мужеви не раде путују просечно краће од мушкараца чије жене не раде што такође доприноси потврди напред поменуте хипотезе да брачни статус доприноси разлици у просечној просторној дистанци путовања према полу.

\section{2. Статистичка анализа и дискусија статистичких резултата}

С обзиром да је утврђено да нису испуњени основни услови за примену анализе варијансе (основни скуп нема нормалан распоред и поред великог "узорка", варијансе нису једнаке за скуп жена и мушкараца) како би се истражио утицај једног или више фактора на варијабилитет просечне дистанце коју дневни мигрант пређе у једном смеру, помоћу софтверског програма SAS коришћен је $t$-тест за испитивање статистичке значајности разлика у просторној раздаљини дневне миграције према полу. "Експериментална истраживања су показала да за примену $\mathrm{t}$-теста претпоставка о нормалној расподели основног скупа у пракси не мора увек бити испуњена, па његову примену можемо да проширимо и на основне скупове који су симетрични и унимодални. Тестирање тада не треба заснивати на малим узорцима" (Žižić M., Lovrić M., Pavličić D., 2000). Увођењем категоријских варијабли за дужину пута тестирана је Chi квадрат тестом једнакост расподеле фреквенција по класама дужине пута, по полу и брачном стању. Израда табела са бројем лица по класама дужине пута, полу и брачном стању и примена Chi квадрат теста помогли су да се уочи потреба за поделом популације по брачном стању, те да се за поједине подскупове примени $\mathrm{t}$-тест.

Услови за примену $t$-теста су: независност, да средње вредности група/подузорака (по полу) имају нормалну расподелу, и да су варијансе ове две групе/подузорака по полу приближно једнаке. ${ }^{25}$ Приликом испитивања средњих вредности узорака предложена је као нулта хипотеза да су аритметичке средине дужине пута према полу једнаке.

Табела 71. Разлике у просечној просторној раздаљини дневне миграције $(\mathrm{km})$ према полу за цео узорак

\begin{tabular}{|l|c|c|}
\hline & Мушкарии & Жене \\
\hline $\mathrm{N}$ & 9.091 & 4.537 \\
\hline Аистанца (km) & 19,58 & 18,57 \\
\hline Стандардна девијација & 9,1 & 8,3 \\
\hline
\end{tabular}

${ }^{25}$ у случају када варијансе нису биле једнаке коришһен је модификовани $\mathrm{t}$-тест Satterthwaite за неједнаке варијансе. 


$\begin{array}{lrrrrr}\text { Variable } & \text { Method } & \text { Num DF } & \text { Den DF } & \text { F Value } & \text { Pr > F } \\ \mathrm{X} & \text { Folded E } & 9090 & 4536 & 1.21 & <.0001\end{array}$

У последњем реду (F-test) видљиви су резултати тестирања једнакости варијанси. $\operatorname{Pr}>\mathrm{F}$ је $<0.0001$, а што је мање од нивоа значајности теста $-0,05$ па се уз ризик од 0,0001 одбацује хипотеза о једнакости варијанси. Користећи $t$ тест Satterthwaite, за неједнаке варијансе, а на основу мале vrednosti $(\operatorname{Pr}<0.0001)$ одбацује се и хипотеза о једнакости аритметичких средина дужина пута по полу, за цео скуп.

T-

$\begin{array}{lllrrr}\text { Variable } & \text { Method } & \text { Variances } & \text { DF } & \text { t Value } & \text { Pr }>|t| \\ \text { x } & \text { Pooled } & \text { Equal } & 14 \mathrm{E} 3 & 6.26 & <.0001 \\ \mathrm{x} & \text { Satterthwaite } & \text { Unequal } & 9883 & 6.46 & <.0001\end{array}$

У даљем поступку, након што су искључени слогови са непознатим брачним стањем дефинисане су следеће варијабле: $x=$ =джина пута; сх има следеће вредности:

- $\quad \mathrm{x}<=10$ онда $\mathrm{cx}=1$,

- $10<\mathrm{x}<=20$ онда $\mathrm{cx}=2$,

- $20<\mathrm{x}<=30$ онда $\mathrm{cx}=3$,

- $30<\mathrm{x}<=40$ онда $\mathrm{cx}=4$,

- $40<\mathrm{x}<=50$ онда $\mathrm{cx}=5$,

- $50<\mathrm{x}<=60$ онда сх $=6$,

- $\quad \mathrm{x}>60$ онда $\mathrm{cx}=7$.

Уведена је нова варијабла брак $2=$ брак. При том брак $2=1$ су самци, брак $2=2$ су лица у браку. Класе брак=3 и брак=4 су спојене због малих фреквенција (3=разведени, 4-удовице/удовци), након чега су урађени тестови расподеле фреквенција по полу и брачном стању.

Табела 72. Разлике у просечној просторној раздаљини дневне миграције $(\mathrm{km})$ према полу за подузорке

\begin{tabular}{|l|c|c|c|c|c|c|}
\hline & \multicolumn{2}{|c|}{ Мушкарци } & \multicolumn{2}{|c|}{ Жене } & \multirow{2}{*}{ t вредност* } & \multirow{2}{*}{ р вредност } \\
\cline { 2 - 5 } & $\mathrm{N}$ & Аистанца (km) & $\mathrm{N}$ & Аистанца (km) & & \\
\hline 6рак2=1 & 1780 & $19,9(9,15)$ & 819 & $20,0(8,99)$ & $-0,13$ & 0,8993 \\
\hline 6рак2=2 & 6917 & $19,5(9,19)$ & 3265 & $18,2(8,23)$ & 7,16 & 0,0001 \\
\hline 6рак2=34 & 390 & $18,9(7,87)$ & 447 & $18,5(7,88)$ & 0,68 & 0,4980 \\
\hline
\end{tabular}

*статистички значајно за р<0.05 (стандардне девијације су дате у заградама)

\section{Хи-квадрат статистика}

Полазећи од претпоставке да жене свакодневно путују на краһим релацијама одлучено је да се тестира Хи квадрат тестом једнакост расподеле фреквенција по класама дужине пута, по полу и брачном стању. 


\begin{tabular}{lccc} 
Statistics for Table of POL by $\mathrm{cx}$ & & \\
Statistic & $\mathrm{DE}$ & Value & Prob \\
\hline Chi-Square & 5 & 37.2376 & $<.0001$ \\
Phi Coefficient & & 0.0523 & \\
Contingency Coefficient & 0.0522 & \\
Cramer's V & & 0.0523 & Sample Size $=13618$
\end{tabular}

Резултат Хи-квадрат теста показује статистички значајну разлику у расподели фреквенција дужина пута по полу за цео скуп. То је и за очекивати јер је већ t-тест показао статистички значајну разлику у средњим вредностима.

Резултат Хи-квадрат теста по полу за брак=1 показује да немамо разлога да одбацимо хипотезу о једнакости фреквенција дужина пута за лица која нису у браку.

Statistics for Table 1 of POL by $c x$

Controlling for brak $2=1$

\begin{tabular}{lccc} 
Statistic & DF & Value & Prob \\
\hline Chi-Square & 5 & 3.4841 & 0.6258 \\
Phi Coefficient & & 0.0366 & \\
Contingency Coefficient & & 0.0366 & \\
Cramer's V & 0.0366 &
\end{tabular}

За лица у браку постоји статистички значајна разлика у фреквенцијама дужина пута према полу, што је такође потврђено t- тестом.

Statistics for Table 2 of POL by $\mathrm{cx}$

Controlling for brak $2=2$

\begin{tabular}{lrrr} 
Statistic & DF & Value & Prob \\
\hline Chi-Square & 5 & 42.2582 & $<.0001$ \\
Phi Coefficient & & 0.0644 & \\
Contingency Coefficient & & 0.0643 & \\
Cramer's V & & 0.0644 &
\end{tabular}

Sample Size $=10182$

Statistics for Table 3 of POL by $\mathrm{cx}$

Controlling for brak $2=34$

WARNING: 258 of the cells have expected counts less than 5 . Chi-Square may not be a valid test.

Због упозорења о недовољном броју јединица по ћелијама за табелу фреквенција дужина пута према полу, а у случају када је брак=34 спојене су и дужине пута (50 и више $\mathrm{km}$ ) и дефинисана нова варијабла за те класе сх2 (brak=34, спојене класе сх 5 и 6 ).

\footnotetext{
${ }^{26}$ Фи $(P / h i)$ је мера зависности заснована на хи-квалрату која укључује поделу хи-квадрат статистике по величини узорка и узимање квацратног корена резултата. Коефицијент контингенције је мера повезаности заснована на хи-квалрату. Вредност овог коефицијента је увек између 0 и 1. Максимална вредност зависи од броја редова и колона у табели. Крамерово $\boldsymbol{B}$ је мера зависности базирана на хиквадрату, која је увек између 0 и 1 и може постиһи вредност 1 за табелу било које димензије.
} 
Statistics for Table of POL by $\mathrm{cx} 2$

\begin{tabular}{|c|c|c|}
\hline Statistic & DF & Value \\
\hline Chi-Square & 4 & 0.0808 \\
\hline Phi Coefficient & & 0.0098 \\
\hline Contingency Coefficient & & 0.0098 \\
\hline Cramer's V & & 0.0098 \\
\hline
\end{tabular}

Sample Size $=837$

Резултат Хи - квадрат теста по полу за брак=34 показује да немамо разлога да одбацимо хипотезу о једнакости фреквенција дужина пута за лица која су разведена или удовице/удовци 


\section{VI ЗАК.ЉУЧАК}

Дневне миграције су феномен релевантан за становништво, привреду, животну средину и друштво у целини. Управо из сложености њихових узрока и последица следи потреба и значај истраживања дневних миграција, као посебног облика просторне покретљивости становништва. Теоретска, али и практична сазнања о процесу дневних миграција (детерминантама, последицама, селективности дневних миграната, временској и просторној димензији дневне миграције, вези између дневне и дефинитивне миграције и др.) доприносе како бољој научној спознаји дневног миграционог процеса, тако и стварању полазних основа за дефинисање мера миграционе а тиме и популационе политике, као и политике локалног и регионалног развоја.

У условима транзиције из индустријског у постиндустријско друштво, која подразумева промене економске структуре и прелазак са индустријске прозводње на доминацију сектора услуга, као и у условима технолошког напретка који омогућава већу просторну покретљивост становништва, везе између места рада и места становања постају све сложеније а тиме и инспиративније са аспекта истраживача који се баве разним научним дисциплинама. Економски аспекти дневних миграција активног становништва, везе између дневних миграција и просторног планирања (најчешће урбане форме), обим и правци дневних миграција у зависности од демографских и социоекономских обележја становништва, импликације дневних миграција на породичне односе као и психичке последице дневних миграција најчешће су истраживане теме везане за процес дневне просторне покретљивости становништва.

У раду је наглашена потреба проучавања дневних миграција и миграција уопште на нивоу домаһинства као јединице анализе. Овај приступ посматра појединца као члана домаћинства/породице, а затим и као припадника одређене друштвене заједнице. Тако се може установити који фактори друштва, поред личних, делују на одлуку о избору одређеног типа миграције. Поред индивидуалних (демографска и социоекономска обележја, аспирације) и друштвено-економских (незапосленост, сиромаштво и др.) детерминанти миграција, међу битним факторима утицаја на миграциони процес су и промене у животном циклусу. Фазе животног циклуса појединца, поред година старости представљене су брачним статусом и родитељством те је посматрање различитих структура домаћинства мигранта веома значајно за откривање детерминанти миграција. Узроци путовања нису исти за све дневне мигранте и проучавање на нивоу домаћинства омогућава сагледавање неких фактора утицаја који нису првенствено економске природе. Разлике међу популацијом дневних миграната и њихових домаћинстава не би требале да се занемарују већ се напротив морају узети у обзир при анализи и предвиђању понашања дневних миграната у миграционом процесу (мисли се на правце и дужину путовања) а за потребе одређених мера и политика.

Имајући у виду могућности трансформације једног типа миграција у други тип, да би се добила потпунија сазнања о дневном миграционом процесу на одређеном простору потребно је истражити везе између различитих облика просторне покретљивости становништва, у зависности од особености демографских и социоекономских структура миграната, мреже насеља, друштвено-економских услова и саобраһајних веза простора полазишта и одредишта.

Динамичност миграционог процеса одражава се на обим и правце токова дневних миграција као и структуру дневних миграната, који су променљиви у зависности од услова у одређеном времену и на датом простору. Дневне миграције данас одвијају се у савременим условима глобализације и експанзије информационих технологија које захтевају високобразовану радну снагу и нове профиле занимања као и 
повећану флексибилност места и времена рада. Упоредо са овим променама мења се и структура домаћинстава и животни стил тј. вредновање одређених аспеката живота од стране појединца, а тиме и правци дневних миграција и однос између различитих облика просторне покретљивости становништва. Зато је континуирано праћење промена у трендовима дневних миграција важан али комплексан задатак.

Анализа дневних миграција становништва на националном нивоу, која је извршена након дискусије теоретских сазнања из ове области, омогућава поређење развоја и савремених тенденција одвијања дневних миграција у Србији и шире. Резултати показују да су дневне миграције у Србији мање изражене у односу на САД и економски развијеније земље Европе, па чак и у односу на неке суседне земље као што је Хрватска. У нашој земљи још увек није започео процес децентрализације, присутан од седамдесетих година двадесетог века у бројним развијеним земљама, те је у већим урбаним центрима изражена концентрација популације и активности. Управо зато токови дневних миграција и даље имају доминантан смер село-град, мада је приметно постепено повеһање интензитета дневних миграција становништва са местом становања у градским насељима. Градови Београд, Нови Сад и Ниш имају најјаче гравитационо дејство још од шездесетих година прошлог века.

Када је реч о дневним миграцијама активног становништва у Србији оне још нису досегле свој пун замах и попримиле све очекиване форме (пораст удела дневних миграција на дужим релацијама, повећан обим дневне миграције правца град-село). Дневне миграције на националном ниову и даље се најинтензивније одвијају у оквирима општина, као што је то био случај и претходних деценија (локалне дневне миграције). Насупрот томе, у свету постоји тренд ка разноврснијим путањама дневних миграција и повећању удела дневних миграција на дуже дистанце у укупном броју свакодневних путовања. Такође се повећава и удео радника који раде део радног времена код куће. Обе ове категорије запослених, за сада карактеристичне за развијене земље и повећану употребу информационе технологије, нису истраживане са аспекта демографске науке код нас. Делимично је томе узрок што су то појаве које су у Србији тек у зачетку, али је сигурно и да недостатку оваквих истраживања доприноси недостатак релевантних података.

Поред разлика у обиму и правцима дневних миграција у Србији у односу на друге земље, које упућују на спорост транзиције дневних миграција у нашој земљи у складу са постојећим друштвено-економским условима, приметне су промене у структури дневних миграната на националном нивоу које су адекватне променама забележеним у другим развијенијим земљама. То су:

- учешће жена у дневним миграцијама се постепено повећава, у складу са све већим образовањем жена и процесом повећања учешћа жена у укупном активном становништву које обавља занимање,

- смањује се удео дневних миграната запослених у примарним и секундарним делатностима, уз пораст учешћа дневних миграната запослених у терцијарним и квартарним делатностима, у складу са променама у структури укупног активног становништва према делатности.

Преовлађујући утицај на обим, правце и структуру токова дневних миграција становништва у нашој земљи имају спољашњи економски и просторни фактори (организација простора - густина мреже насеља и величина насеља, и саобраћајни услови). Стога дневне миграције у Србији представљају првенствено одраз неравномерног привредног развоја између насеља и општина и изражене концентрације функција у појединим градским центрима. Други фактори који утичу на одлуке везане 
за процес дневних миграција у Србији и просторну дистанцу путовања испитани су на примеру дневних миграната Панчева (због посебне обраде података за ову групу дневних миграната) па из тога можемо извући закључке везане за карактеристике породице дневног мигранта и утицај фазе животног циклуса на дневну миграцију.

У овом раду тежиште је било на проучавање конвергентних и дивергентних токова дневних миграција становништва у дневном урбаном систему Панчева, уз уважавање релевантних елемената и фактора дневних миграција као и комплексности овог облика просторне покретљивости становништва. Зато су приликом проучавања узете у обзир везе и односи између популационог и друштвено-економског развоја који су резултирали датим степеном развијености дневних миграција на посматраном простору. На обим, територијални домет и структуру савремених дневних миграција у урбаном систему Панчева утицали су:

- гео-саобраћајни и друштвено-економски положај Панчева,

- популациона динамика и промене у просторном размештају становништва,

- природна и миграциона компонента демографског развоја,

- достигнути степен развијености дневних миграција,

- промене у основним структурама становништва (биолошким и социоекономским),

- промене броја и основних обележја домаћинстава (величине домаћинстава према броју чланова, породичног састава и економских обележја домаћинстава),

- функционални развој Панчева (првенствено улога индустрије), и

- стање и процеси на тржишту рада.

Ако се имају у виду подаци о популационој динамици на простору општине Панчево у последњем међупописном периоду, може се закључити да да није било пораста обима дневних миграција, стопа пораста дефинитивних миграција становништва Панчева би порасла, с обзиром да би становништво било принуђено да се ослони на дефинитивне миграције као начин за добијање новог посла. Анализе показују да је на простору општине Панчево нарочито важно задржавање ресурса младог становништва које по први пут тражи запослење. Подстицање учешћа жена на тржишту рада такође може позитивно утицати на број радно активног становништва.

Специфичност Панчева која се огледа у ширем националном и регионалном значају панчевачке индустрије важна је полазна основа приликом проучавања дневних миграција становништва у урбаном систему Панчева. Велика индустријска постројења на простору општине Панчево директно утичу на обим и правце дневних миграционих токова економски активног становништва. Други битан фактор утицаја на развој дневних миграција у урбаном систему Панчева јесте непосредна близина Београда административног, привредног, културног, универзитетског и сваког другог центра државе и средишта бројних и разноврсних функција, са којим, што је изузетно значајно, постоје добре саобраһајне везе. Зато hе од промена у структури панчевачке привреде (првенствено трансформације и приватизације великих индустријских комплекса), и промена у јачини функционалних и саобраћајних веза са Београдом у највећој мери зависти даљи развој дневних миграција у урбаном систему Панчева и трансформације њиховог обима, праваца и структуре. Не треба заборавити, наравно, још једну специфичност Панчева, нужно проузроковану концентрацијом и типом индустрије развијене на овој локацији, коју чини висок степен загађености животне средине. У садашњим условима функционисања тржишта радне снаге и некретнина, који се директно одражавају на релатвно ниску просторну покретљивост становништва, и 
поред развијене еколошке свести становништво није у могућности да лако промени место становања. Зато се делом и одржава облик дневне просторне покретљивости становништва на овом простору. Логично је претпоставити да ће са очекиваним растом стандарда становништво логично тежити становању у мање загађеним местима, нарочито уколико тамо већ остварује функцију рада. Зато је увођење еколошких стандарда у производњу један од предуслова за задржавање барем дела дневних миграната Панчева и смањење обима дефинитивних пресељавања.

Посебна обрада података о дневним мигрантима, од стране служби Републичког завода за статистику Србије, пружила је могућности за дефинисање функционалног подручја Панчева и његовог дневног урбаног система и за стицање сазнања о структури дневних миграната (демографски профил дневног мигранта урбаног система Панчева ко су и где иду). Резултати анализе показују да:

- у периоду 1961-2002. година није било знатнијих промена већ формираног панчевачког функционалог подручја, нити његовог просторног ширења;

- у складу са доминацијом индустријске производње, која карактерише општину Панчево, две трећине дневних миграната чини активно становништво, а једну трећину ученици/студенти;

- доминација функције рада и њима кореспондирајући токови дневних миграција одлика су дневних миграционих токова правца Београд Панчево у којима преко $95 \%$ чини активно становништво;

- висока је заступљеност локалних дневних миграција (локални дневни мигранти чине $70,6 \%$ у структури конвергентних токова активних дневних миграната док $29,4 \%$ чине спољашњи дневни мигранти);

- град Панчево има позитиван гравитациони биланс само захваљујући апсорпцији локалних дневних миграната;

- највећи број дневних миграната долази из београдских општина (претежно из Палилуле и Новог Београда) и насеља на простору суседних банатских општина: Баваниште, Мраморак и Ковин у општини Ковин, и Црепаја у општини Ковачица, а највише миграната одлази ка београдским општинама и насељима (Алибунар, Ковачица, Ковин и Падинска Скела) у некој од суседних општина;

- у укупној маси дневних миграционих токова са простора општина Ковин и Ковачица, токови према општини Панчево чине $43,3 \%$ и $39,5 \%$, односно $25 \%$ за општину Алибунар;

- од других општина, осим београдских, које свакодневно примају радну снагу са простора општине Панчево, нешто значајнији су само токови радне снаге ка општини Ковин, односно њеном општинском средишту;

- ако се посматра тип насеља полазишта дневних миграната, ученици долазе већином из сеоских насеља, док разноврсне функције Панчева привлаче како раднике који живе у градским, тако и раднике који живе у сеоским насељима;

- веће учешће мушкараца у дневним миграцијама, на примеру Панчева, потврђује сазнања и других аутора о мањем учешћу жена од мушкараца у дневним миграцијама;

- међу радницима дневним мигрантима Панчева већина је у браку. У структури дивергентних токова у односу на конвергентне више је заступљен проценат лица која нису у браку;

- више од половине дневних миграната старости је између четрдесет и педесет девет година; 
- захваљујући јаком градском индустријском центру Панчево, као што је и очекивано, највише привлачи раднике запослене у секундарном сектору делатности (прерађ)ивачка индустрија). Структура дивергентних дневних миграната према секторима делатности је са прилично равномерним уделима запослених у секундарним, терцијарним и квартарним делатностима;

- највише дневних миграната је са завршеном средњом школом. Конвергентни активни дневни мигранти имају неповољнију образовну структуру од дивергентних, чему доприноси мушка популација. Поређењем структуре активног становништва општине Панчево које обавља занимање и структуре активног становништва које учествује у дневним миграционим токовима радне снаге потврђена су теоретска сазнања о већој просторној покретљивости образованијег становништва;

- највећи број дневних миграната не поседује пољопривредно имање, као индикатор евентуалне двојне делатности. Већа везаност за пољопривредно домаћинство запажена је само када је реч о запосленим дневним мигранатима који свакодневно путују у оквиру граница општине Панчево из насеља Банатско Ново Село, Долово и Глогоњ;

- велика већина дневних миграната живи у стамбеном објекту који је у власништву његове породице. То је потврда теоретских сазнања да се власници стамбених јединица/објеката чешће одлучују на овај облик миграције у односу на дефинитивну миграцију;

- домаћинства дневних миграната урбаног система Панчева претежно чине нуклеарне породице са подједнаким уделом породица са једним и двоје запослених супружника. У већини породица у дневној миграцији учествује један супружник и то је најчешће мушкарац. Ако у породици има чланова млаһих од седам година (деца предшколског узраста) процентуални удео породица у којима оба супружника учествују у дневним миграцијама се смањује и у том случају најмањи је удео породица у којима путује само жена. То је потврда ограничавајућег деловања породичних и фактора родитељства на учешће жена у дневном миграционом процесу;

- преовладавање алохтоног становништва у токовима дневних миграција активног становништва потврда је теоретских сазнања о вези између различитих облика миграционих кретања, према којима особе са претходним миграционим искуством имају већу склоност ка учешћу у неком од облика просторне покретљивости становништва.

Утврђивање фактора који утичу на дневне мигранте омогућава примену одговарајућих мера са циљем усмеравања и управљања дневним миграцијама а такође је предуслов предвиђања њиховог обима и праваца у будућности. Из резултата тестирања утицаја демографских и социо-економских фактора на просечну дужину путовања дневног мигранта у једном смеру види се да је просторна раздаљина дневне миграције жена у урбаном систему Панчева увек мања у односу на мушкарце. То потврђује сазнања у међународној литератури на ову тему о краһем путовању жена до посла. Додељивање варијабле дужина пута дневном мигранту омогућило је сазнања и потврду различитог деловања демографских и социо-економских фактора на просторну раздаљину дневне миграције за мушкарце и жене. Жене већином путују на краћим раздаљинама од мушкараца који су истог образовања, раде у истом сектору делатности, имају исте породичне карактеристике и путују у истом смеру. 
Утицај образовања на просечну просторну раздаљину дневне миграције је приметан, мада више када је реч о женској популацији. Можемо закључити да образовање генерално повећава просторне дистанце активних жена које учествују у дневној миграцији. До истих сазнања дошла је Кристалди Ф. која истиче значај образовања као статистички најзначајне варијабле за путање дневних миграција жена у Италији. Жене са лошијим образовним квалификацијама путују на краће дистанце и обрнуто (Cristaldi F., 2005).

Године старости немају већег утицаја на просечну дистанцу путовања активног дневног мигранта урбаног система Панчева, што је потврда сличних истраживања о факторима утицаја на дневну миграцију (Lee B. S., J. Mc Donald, 2003; Schwanen T., F.M. Dieleman, M. Dijst,2004).

У појединим категоријама становништва алохтони дневни мигранти путују даље до посла у односу на аутохтоне. Чињеница да алохтони радници-жене путују просторно даље од аутохтоних указује да нека пресељења нису проузрокована тежњом радника да буду ближе месту рада већ другим разлозима (нпр. удаја).

Испитивање како присуство два радника у домаћинству утиче на однос места рада и места становања, на примеру Панчева, је показало да нема значајнијих разлика у просечној дистанци путовања између жена и мушкараца у породицама где ради један и у породицама где ради двоје супружника.

Брачни статус и присуство деце, као најчешће коришћени индикатори за испитивање хипотезе о одговорности у домаћинству, показали су се значајни и за варијације у просторној раздаљини дневне миграције према полу и на примеру дневних миграната Панчева. Жене које нису у браку путују краће од жена у браку. У домаћинствима где обоје супружника ради жене путују на краћим раздаљинама од мушкараца, што потврђује хипотезу о већој одговорности жена у домаћинству. Жене чији мужеви не раде путују просечно краһе од мушкараца чије жене не раде што такође доприноси потврди напред поменуте хипотезе.

Деца предшколског узраста нису значајнији фактор утицаја на разлике у дистанцама дневних миграната према полу. Испитивањем ефеката породичне структуре на просторну раздаљину дневне миграције према полу утврђено је да проширено домаћинство није олакшавајући фактор у случају дневне миграције жена Панчева, односно да жене у вишепородичним домаћинствима путују просторно краће. То је супротно сазнањима истраживања на примеру Сеула (види Lee B. S., J. Mc Donald, 2003), а слично сазнањима других аутора (види Hanson S., I. Johnston, 1985).

Постоје статистички значајне разлике у дужини путовања дневних миграната Панчева према полу генерално, као и разлике у дужини путовања према полу у категорији лица која су у браку. Коришћењем t-теста за тестирање разлика средина дужина пута по полу добијена је статистички значајна разлика, па се одбацује хипотеза о једнакости средина за цео скуп. Тестирање према брачном стању показује да за брачно стање брак=1 (самци), и за брачно стање 3 и 4 (заједно разведени/удовице и удовци) не постоји статистички значајна разлика у расподели фреквенција по класама дужине пута, а и t-тест, посебно за ове две групе је показао да се једнакост средина не може одбацити. Статистички значајна разлика у расподели фреквенција по класама дужине пута постоји за подскуп брак=2 (лица у браку). Т-тестом је такође добијена статистички значајна разлика средина дужина пута по полу за овај подскуп.

Негативан природни прираштај становништва у Панчеву, али и већини општина Србије одражава се и на прилив становништва у контингент радно способног становништва. Зато свака општина и насеље треба да теже да задрже своје становништво, пружајући му услове за становање и запослење, јер емиграција радне снаге на дужи рок није ни економски ни демографски прихватљива с обзиром да води 
даљем слабљењу популационих потенцијала. У зависности од степена друштвеноекономске развијености, а самим тим и могућности које локална заједница пружа у погледу радног ангажовања становништва, уколико запошљавање становништва није могуће у локалним предузећима (било услед обима или структурне неусклађености радне снаге), један од начина да се пружи шира могућност запослења и спречи емиграција и одлазак кадрова јесте управо путем дневних миграција. Да би се то остварило неопходно је унапређење саобраћајне инфраструктуре као предуслов за брже и лакше одвијање дневних миграција

Истраживања дневних миграција становништва само на примеру Панчева не пружају довољно података за уопштавања на националном нивоу. Ово проучавање је зато само један од примера могућег истраживања. Слична проучавања и у другим градовима Србије са различитим бројем становника и степеном и диверзитетом развијених функција знатно би допринела проширивању сазнања о разликама у обиму и правцима дневних миграција у Србији различитих категорија становништва, и везама између дневних миграција и демографског и друштвено-економског развоја. Зато будућа истраживања овог облика просторне покретљивости становништва треба да наставе потпуније сагледавање свих елемената и фактора дневног миграционог процеса и њихових интеракција. Само тако се може доћи до сазнања да ли овај облик просторне покретљивости становништва има позитивне (одржавање демографске виталности, смањивање економских неједнакости, побољшање квалитета живота и др.) или негативне ефекте на развој насеља становања и рада, који упућују у ком случају је потребно подстицати дневну миграцију насупрот дефинитивној, а одговарајућим интервентним мерама у склопу развојних политика. За различите категорије дневних миграната (познавајући њихове личне и карактеристике и тип домаћинства) потребно је применити и различите мере. 


\section{ЛИТЕРАТУРА И ИЗВОРИ:}

1. Аџић С., (2006): Транзиција и промена економске структуре становништва Војводине између два пописа, Зборник Матице Српске за друитвене науке, Бр. 121, стр.269-281, Нови Сад.

2. Bobić M., (1999): Savremena seoska porodica i domaćinstvo u Jugoslaviji, Stanovništvo, 1-4, str.93-118, CDI-IDN, Beograd.

3. Брезник Д., (1980): Демографија-анализа методи и модели, Научна књига, Београд.

4. Букуров Б., (1970): Гравитационе сфере војвођанских градова; Посебна издања САНУ, Споменица књ. 44, стр.117-138, Београд.

5. Бурсаћ М., (2003): Ниво квалификованости становништва у функцији регионализације, у: Демографске основе регионализачије Србије, ур. М. Спасовски, Посебна издања Књ. 54, Географски институт “Јован Цвијић” САНУ, стр.189-199, Београд.

6. Бјељац Ж., (1992): Структуре дневних миграната у општини Беочин, Збориик Матице Српске за друитвене иауке, Бр.92-93, стр.95-106, Нови Сад.

7. Вељковић А., Р. Јовановић, Б. Тошић (1995): Градови Србије - цеитри развоја у мрежи насеља, Посебна издања Књ. 44, Географски институт "Јован Цвијић” САНУ, Београд.

8. Vresk M., (1982-1983): Neka obilježja urbanizacije SR Hrvatske 1981. godine, Geografski odjel PMF, Radovi 17-18, str. 39-53, Zagreb.

9. Vresk M., (1984): Razvoj urbanih sistema u svijetu, Školska knjiga, Zagreb.

10. Vresk M., (1990): Osnove urbane geografije, Skolska knjiga, Zagreb.

11. Đošić D., (1970): Razvoj stanovništva Pančeva i njegova perspektiva, Stanovništvo, 34, str.218-233, CDI-IDN, Beograd.

12. Ђурђев Б., (1986): Послератно насељавање Војводине, Матица Српска, Нови Сад.

13. Žagar M., (1959): Uticaj industrije na okolinu, V Kongres geografa, str. 447-449, Podgorica.

14. Живковиһ М., (1980) Покретљивост радне снаге (дневне митрације), Гледишта бр.6, Београдски Универзитет и Републичка конференција ССО Србије, Београд.

15. Žižić M., M., Lovrić, D., Pavličić (2000): Metodi statističke analize, Univerzitet u Beogradu Ekonomski fakultet, Beograd.

16. Žuljić S., (1970): Stupanj urbaniziranosti Jugoslavije važno obilježje i činilac razvitka, Geografski Glasnik, Br. 32, str. 101-122, Zagreb.

17. Илић J., (1967): Привредно-географске карактеристике Панчева и околине и њихови међусобни односи и везе, Докторска дисертација у рукопису, Географски факултет, Београд.

18. Ilić J., (1970): Karakteristike funkcionalnih odnosa između grada i okoline sa posebnim osvrtom na SR Srbiju, Stanovništvo, 3-4, str. 167-189, IDN-CDI, Beograd.

19. Ilić J., (1971): Karakteristike geografskog položaja Pančeva i njegov značaj za razvoj grada, Zbornik radova PMF, Univerzitet u Beogradu, Sv. XVIII, str.91-103, Geografski zavod, Beograd.

20. Кицошев С., М. Бубало-Живковиһ, А. Ивков (2005): Становништво Баната, Универзитет у Новом Саду, ПМФ-Департман за географију, туризам и хотелијерство, Нови Сад.

21. Klemenčić V., (1962): Geografski problemi i metode proučavanja svakodnevnog putovanja radne snage od mesta stanovanja na rad i obratno. Zbornik VI Kongresa Geografa FNRJ, str. 291-296, Ljubljana. 
22. Klemenčić V., (1964): Transformacija prigradske zone, Zbornik VII Kongresa geografa SFRJ, str. 211-225, Zagreb.

23. Кубуровић А., (2006): Демографска слика породице у Војводини према попису 2002. године, Зборник Матице Српске за друитєене науке, Бр. 121, стр. 29-39, Нови Сад.

24. Лукић В., (2006): Дневне мигращије активног становништва у Србији, Гласник српског географског друитва, Бр. 1., Св. LXXXVI, стр.141-150, Београд.

25. Лукић В., (2007): Селективност дневних миграната у Србији према полу, Гласник српског географског друитеа, Вол. 87., Бр. 2, стр. 67-78.

26. Матијевић Д., (2007): Просторно функционална повезаност насеља Старе Пазове са урбаним системом Београда, магистарски рад у рукопису, Географски факултет, Београд.

27. Мацура М., (1954): Критеријум за разграничење градског и сеоског становништва, Статистичка ревија, Бр. 3-4, стр.371-377, Југословенско статистичко друштво, Београд.

28. Мацура М., (1965): Модели просторне покретљивости радне снаге и капитала, Економист, Бр. 3., стр.423-429, Београд.

29. Macura M., (1965): Razmatranja o odnosima između stanovništva i privrede, Stanovništvo, 1, str.5-11, IDN-CDI, Beograd.

30. Мацура М., (1974): Прилози теорији и политици становниитва, Економски институт, Београд.

31. Милетиһ Р., (1999): Везе и односи индустрије и околног геопростора на примеру општине Панчево, магистарски рад у рукопису, Географски факултет, Београд.

32. Миљановић Д., (2001): “Теоријско поимање и одређење одрживог развоја као нове парадигме развоја", XIV Конгрес географа Југославије, стр.163-169, Београд.

33. Министарство за људска и мањинска права Србије и Црне Горе, (2004): Избеглички корпус у Србији, Београд

34. Петровић Г., (2001): Дневне миграције становништва општине Инђија и њихове последице, магистарски рад у рукопису, Географски факултет, Београд.

35. Петровић Р., (1979): Другтво и становниитво, Економски институт, Београд.

36. Р3С, (1992а): Опитине у Републиии Србији, Београд.

37. Р3С, (1992б): Документащиона табела бр.12., Становништво према миграшионим обележјима, Попис становништва 1991. године, Београд.

38. Р3С, (1992в): Документациона табела бр.29., Досељено становништво према општини из које се доселило и општини сталног становања, Попис становништва 1991. године, Београд.

39. Р3С, (1993): Попис становниитва 1991, Књ 3.,Београд.

40. Р3С, (2003а): Отитиие у Републици Србији, Београд.

41. Р3С, (2003б): Попис становниитва, домаћинстава и станова 2002, Књ.2, Пол и старост, Београд.

42. Р3С, (2003в): Попис становниитва, домаћинстава и станова 2002, Књ. 3, Вероисповест, матерњи језик и национална или етничка припадност према старости и полу, Београд.

43. Р3С, (2003г): Попис становниитва, домаһинстава и станова 2002, Књ.5, Активност и пол, Београд.

44. Р3С, (2003д): Попис становниитва, домаћинстава и станова 2002, Књ.4, Школска спрема и писменост, Београд.

45. Р3С, (2004а): Попис становниитва, домаћинстава и станова 2002, Књ.13, Дневни мигранти, Београд. 
46. Р3С, (20046): Попис становништва, домаћинстава и станова 2002, Књ. 9 , Упоредни преглед броја становника 1948-2002, Београд.

47. Р3С (2004в): Попис становниитва, домаћинстава и станова 2002, Књ.8, Миграциона обележја, Београд.

48. Р3С, (2004г): Попис становниитва, домаһинстава и станова 2002, Књ. 6, Делатност и пол, Београд.

49. Р3С, (2004д): Попис становниитва, домаћинстава и станова 2002, Књ. 7, Пољопривредно становништво, Београд.

50. Р3С, (2004ђ): Попис становниитва, домаһинтава и станова 2002, Књ. 10 , Упоредни преглед домаћинстава и станова, Београд.

51. Р3С, (2004е): Попис становниитва, домаћинстава и станова 2002, Књ. 11, Домаћинства према поседовању пољопривредног газдинства, Београд.

52. Р3С, (2004ф): Попис становниитва, домаћинстава и станова 2002, Пољопривреда, Књ. 2, Београд.

53. Р3С, (2005): Документациони материјал виталне статистике, Београд.

54. Р3С, (2005а): Опитине у Републици Србији, Београд.

55. Р3С, (2006а): Подаци о дневним миграцијама становништва (1981,1991 година), Београд.

56. Р3С, (2006б): Посебна обрада података Пописа становништва из 2002. године, Активно становништво према школској спреми, Београд.

57. P3С, (2006в): Документациона табела бр.2., Досељено становништво према времену досељења, старости у време досељења и подручју са кога је досељено, Попис становништва 2002, Београд.

58. Р3С, (2007): Посебна обрада података Пописа становништва из 2002. године, Београд.

59. Р3С, (2007а): Регистар правних лица и приватних предузетника, Београд.

60. Радовановић М., (1968): О неким питањима етнолошког проучавања дневних миграција, Цвијићев Зборник у спомен 100 годишњице његовог рођења, САНУ, Одељење Природно-математичких наука, стр.207-214, Београд.

61. Радовановић М., (1996): Антропогеографске и демографске основе развоја насељености у Србији, Зборник радова Географског института "Јован Цвијић" САНУ, Књ. 43, стр. 57-90, Београд.

62. Радушки Н., (2005): Значај миграција и националног изјашњавања у промени етничке структуре Србије почетком XXI века, Зборник Матице Српске за друитвене науке, Бр. 118-119, стр.383-395, Нови Сад.

63. Roca O., (1986): Migracija radnika u Zagreb: Geografski aspekt prostorne pokretljivosti i problematike, doktorska disertacija u rukopisu, Zagreb.

64. Савић О., (1962): Изохрона и изотелна карта околине Београда, Збориик радова Географског института “Јован Цвијић” САНУ, Књ.18., стр. 173-190, Београд.

65. SZS, IDN-CDI, (1995): Stanovništvo i domaćinstva SR Jugoslavije prema popisu stanovništva 1991. godine, ur. S. Radovanović, Beograd.

66. С3С, (1965a): Попис становниитва 1961, Књ.11, Пол и старост, Београд.

67. СЗС, (19656): Попис становниитва 1961, Књ.14., Активност и делатност, Београд.

68. СЗС, (1965в): Попис становниитва 1961, Књ.13, Школска спрема и писменост, Београд.

69. СЗС, (1965г): Попис становништва 1961, Књ.16, Величина и извори прихода домаћинстава, Београд.

70. СЗС, (1966): Попис становниитва 1961, Књ.12, Миграциона обележја, Београд. 
71. СЗС, (1967): Попис становниитва 1961., Књ.6, Витална, етничка и мигращиона обележја, Београд.

72. СЗС, (1971): Билтен Бр.96, Београд.

73. СЗС, (1973а): Попис становниитва 1971, Књ. 9, Миграциона обележја, Београд.

74. С ЗС, (19736): Попис становниитва 1971, Књ. 8, Пол и старост, Београд.

75. СЗС, (1973в): Попис становниитва 1971, Књ. 11, Пољопривредно становништво, Београд.

76. СЗС, (1974а): Попис становниитва 1971, Књ. 3, Економске карактеристике I део, Београд.

77. СЗС, (19746): Попис становниитва 1971, Књ. 10, Становништво према делатности, Београд.

78. СЗС, (1974в): Попис становниитва 1971, Књ. 2, Писменост и школство, Београд

79. СЗС, (1974r): Попис становниитва 1971, Књ. 6, Етничка, просветна и економска обележја и домаћинства према броју чланова, Београд.

80. СЗС, (1974д): Попис становниитва1971, Књ. 5, Домаћинства и породице, Београд, 1974.

81. СЗС, (1974)): Попис становништва 1971, Књ. 12, Величина поседа и извори прихода домаћинстава, Београд.

82. СЗС, (1995): Попис становниитва 1991, Књ. 5, Домаћинства, пољопривредно становништво и фондови домаһинстава, Београд.

83. СЗС, Р3С, (2002): Први резултати пописа становниттва домаћинстава и станова, 2002, Билтен 422, Београд.

84. Stamenković S., (1987): Neki aspekti proučavanja dnevnih migracija stanovništva za potrebe prostornog planiranja, Zbornik radova XII Kongresa geografa Jugoslavije, str. 412-415, Novi Sad.

85. Стаменковић С., (1989): Дневне миграције становниитва (радне снаге и иколске омладине) према централним насељима у врањском крају, СГД - Посебна издања Књ. 68., Београд.

86. Стаменковић С., М. Бачевић (1992): Географија насеља, Географски факултет Универзитета у Београду, Београд.

87. Стаменковић С., М. Павловић, Д. Тошиһ, М. Милинчиһ (1995): Диевне миграције становниитва (радне снаге и ученика) према Александровцу и Брусу, Географски факултет Универзитета у Београду, Посебна издања Књ. 4., Београд.

88. Stamenković S., (1996): Dnevne migracije stanovništva u geografskim proučavanjima naselja Srbije, Stanovništvo, 3-4, str.43-60, IDN-CDI, Beograd.

89. Станковић В., (1996): Значај емпиријског потенцијала демографске статистике за мултидисциплинарно проучавање просторно-демографских појава, Зборник радова Географског института “Јован Цвијић” САНУ, Књ. 46, стр. 249-263.

90. Stanković V., M. Žižić, S. Kapuran (2000): Census Documentation in Studying Migration Processes in Yugoslavia Statistique, Développement et Droits de 1'Homme, Montreux, 4-8/9.

91. Stevanović R., (2004): Gradska naselja Republike Srbije u popisima stanovništva od 1948. do 2002., Stanovništvo, 1-4, str. 109-125, IDN-CDI, Beograd.

92. Стојановиһ Б., (2003): Размештај и густина становништва као основа регионализације у: Демографске основе регионализације Србије, ур. М. Спасовски, Посебна издања Књ. 54, стр.73-114, Географски институт "Јован Цвијић" САНУ, Београд.

93. Šešić B., (1980): Opšta metodologija, Beograd.

94. Томић П., Ј. Ромелић, (2003): Индустрија Баната, Универзитет у Новом Саду ПМФ Департман за географију, туризам и хотелијерство, Нови Сад, 
95. Тошић Д., (1999): Просторно-функцијски односи и везе у нодалној регији Ужица; докторска дисертација у рукопису, Географски факултет, Београд.

96. Тошић Б., Д. Матијевић, В. Лукић, (2004): Дунавско-моравски коридор:насеља, Посебна издања Књ. 62, Географски институт “Јован Цвијић” САНУ, Београд.

97. Ћурчић С., (1993): Формирање приградских зона у Војводини, Зборник радова Географског факултета Универзитета у Београду, Св. 41., стр. 17-25.

98. Ћурчић С., (2004): Насеља Баната, Матица Српска, Нови Сад.

99. Ћурчић С., (2005): Биолоике структуре становниитва Војєодине, Књ. I и II, Матица Српска, Нови Сад.

100. Универзитет у Новом Саду, ПМФ - Институт за географију, (1996): Опитина Паичево, Географске монографије војвоһанских општина, Нови Сад.

101. Урбанистички Завод Београда, (2002): Регионалии просторни план административног подручја Београд, Београд.

102. Friganović M., (1968): Demografija- stanovništvo svijeta, Školska knjiga, Zagreb.

103. Friganović M., (1970): Gravitacijske zone dnevne migracije u radne centre Hrvatske, Geografski Glasnik, Br.2, str.89-99, Zagreb.

104. CDI-IDN, (1970): Demografski razvitak Pančeva, Beograd.

105. CDI-IDN, (1971): Migracije stanovništva Jugoslavije, Beograd.

106. ШИИ-ИДН, (1979): Развитак становништва СР Србије и промене до 2000. године, Београд.

107. CDI-IDN, (2004): Stanovništvo, 1-4, Prilozi, Beograd.

108. Centar za visoke ekonomske studije, (2006): Mapa tržišta rada Srbije: ocena regionalnih rizika i potencijala, ur. Mihail Arandarenko, Beograd.

109. www.arhivpancevo.org.yu

110. www.dzs.hr

111. www factis.co.yu

112. www.pancevo.org.yu

113. www.rztr.co.yu

114. www.rnp.co.yu

115. www.rpkpancevo.com 


\section{ЛИТЕРАТУРА И ИЗВОРИ НА ЕНГЛЕСКОМ ЈЕЗИКУ:}

1. Artis M., J. Romani, J. Surinach, (2000): Determinants of Individual Commuting in Catalonia, 1986-1991: Theory and Empirical Evidence, Urban Studies, Vol.37, No 8, pp. 1431-1450.

2. Brown D. L., (2002): Migration and Community: Social Networks in a Multilevel World. Rural Sociology, Vol. 67, Issue 1, pp. 1- 23.

3. Bunker B., J. M. Zubek, Vanderslice R., W. Rice, (1992): Quality of Life in DualCareer Families: Commuting versus Single-Residence Couples, Journal of Marriage and the Family, Vol. 54, No. 2., pp. 399-407.

4. Camstra R., (1996): Commuting and Gender in a lifestyle perspective, Urban Studies, Vol. 33, No 2, pp. 283-336.

5. Clark W. A., Kuijperslinde M., (1994): Commuting in restructuring urban regions, Urban Studies, Vol.31, No 3, pp.465-483

6. Costa G, L. Pickup, V. Di Martino (1988): Commuting/a further stress factor for working people: evidence from the European Community, International Archives of Occupational and Environmental Health, Vol 6., No 5, pp.377-385.

7. Cristaldi F.,(2005): Commuting and Gender in Italy: A Methodological Issue, The Professional Geographer, Vol. 57, Issue 2, pp. 268-284.

8. De Vise P., (1976): The Suburbanization of Jobs and Minority Employment, Economic Geography, Vol. 52, No. 4. pp. 348-362.

9. Dickinson R. E., (1957): The Geography of Commuting: The Netherlands and Belgium, Geographical Review, Vol. 47, No. 4. pp. 521-538.

10. Eliasson K., U. Lindgren, O. Westerlund, (2003): Geographical Labour Mobility: Migration or Commuting?, Regional Studies, Vol. 37, Issue 8, pp. 827-837.

11. Edwards C., (2005): Long-distance commutes increase by a third, RGS-IBG annual conference (31 August - 2 September), www. geographical co.uk.

12. Ericksen J. (1977): An analysis of the journey to work for women, Social Problems, Vol.24, No 4, pp. 428-435.

13. Evans G., Wener R.., Philips D., (2002): The Morning Rush Hour - Predictability and Commuter Stress, Environment and Behavior, Vol.34, No 4, pp.521-530.

14. Fisher J., Mitchelson R., (1981): Extended and Internal Commuting in the Transformation of the Intermetropolitan Periphery, Economic Geography, Vol. 57, pp. 189-207.

15. Fuguitt G. V., (1991): Commuting and The Rural - Urban Hierarchy, Journal of Rural Studies, Vol.7, No 4, pp. 459-466.

16. Giuliano G., K.A. Small (1993): Is the journey to work explained by urban structure?, Urban Studies, No 30, pp.1485-1500.

17. Goldstein S., K. Mayer, (1964): Migration and the Journey to Work, Social Forces, Vol. 42, No. 4. pp. 472-481.

18. Goldstein S., (1987): Forms of Mobility and Their Policy Implications Thailand and China Compared, Social Force,s, Vol. 65, No 4, pp. 915-942.

19. Gordon P., B. Lee, H. W.Richardson, (2004): Travel trends in U.S. Cities: Explaining the 2000 Census Commuting Results, Lusk Center for Real Estate University of Southern California, LosAngeles.

20. Green A. E., T. Hogarth, R. E. Shackelton (1999): Longer Distance Commuting as a Substitute for Migration in Britain: A Review of Trends, Issues and Implications, International Journal of Population Geography, Vol.5, pp. 49-67.

21. Hamilton B. W., A. Roell, (1982): Wasteful Commuting, The Journal of Political Economy, Vol. 90, No. 5.pp. 1035-1053. 
22. Hazans M., (2004): Does Commuting Reduce Wage Disparities? Growth and Change, Vol. 35, No. 3, pp. 360-390.

23. Hanson S., I. Johnston (1985): Gender differences in work-trip lenghts: Explanations and implications, Urban Geography, 6 (3), pp. 193-219.

24. Hanson S., G. Pratt, (1988): Reconceptualizing the Links between Home and Work in Urban Geography, Economic Geography, Vol. 64, No. 4. pp. 299-321.

25. Hanson S., G. Pratt, (1991): Job search and the occupational segregation of women, Annals of the Association of American geographers, 81(2), pp. 229-253.

26. Holmes J., (1971): External Commuting as a Prelude to Suburbanization, Annals of the Association of American Geographers, Vol.61, No.4, pp. 774-790.

27. Horner M. W., (2004): Spatial Dimensions of Urban Commuting: A Review of Major Issues and Their Implications for Future Geographic Research, The Professional Geographer, Vol. 56, Issue 2, pp. 160-173.

28. Johnston-Anumonwo I., (1992): The Influence of Household Type on Gender Differences in Work Trip Distance, Professional Geographer, 44 (2), pp. 161-169.

29. Jones H., (1976): The Structure of the Migration process: Findings from a Growth Point in Mid- Wales Transactions of the Institute of British Geographers, New Series Vol 1., No 4, pp. 421-432

30. Kain J., (1962): The journey to work as a determinant of resident location, Papers of the Regional Science Association, Vol 9. pp. 130-160.

31. Kain J., (1968): Housing segregation, negro employment ana metropolitan decentraliyation, Quarterly Journal of Economics, 82, pp.175-197.

32. Lee E.S., (1966): A Theory of Migration, Demography, Vol. 3, pp. 47-57.

33. Lee B. S., J. Mc Donald, (2003): Determinants of Commuting Time and Distance for Seoul Residents: The Impact of Family Status on the Commuting of Woman, Urban Studies, Vol. 40, Issue 7, pp. 1283-1302.

34. Levinson D., (1998): Accessibility and the journey to work, Journal of Transport Geography, Vol. 6, No 1, pp. 11-21.

35. Levinson D., Kumar. A. (1994): The Rational Locator: Why Travel Times Have Remained Stable, Journal of the American Planning Association, 60:3, pp. 319-332.

36. Levinson, D. (1999): Space, Money, Life-cycle, and the Allocation of Time, Transportation 26, pp.141-171.

37. Lonsdale R. E., (1966): Two North Carolina Commuting Patterns, Economic Geography, Vol. 42, No. 2., pp. 114-138.

38. Lu M., (2002): Are Pastures Greener? Residential Consequences of Migration, International Journal of Population Geography, 8,

39. Mc Dowell C., A. de Haan, (1997): Migration and Sustainable Livelihoods: A Critical Review of the Literature, IDS Working Paper 65.

40. Madden, J. F. (1981): Why women work closer to home, Urban Studies Vol.18, Issue 2, pp.181-1194.

41. Mincer J., (1978): Family Migration Decisions, The Journal of Political Economy, Vol.86. No5, pp.749-773.

42. Nasser H. E. (2002): Census: Home is where work is, USA TODAY.

43. Nilles J., (2000): Telework America Research JALA International.

44. OECD (2005): OECD Employment Outlook 2005.

45. Owen D., A. E. Green, (2000): Estimating Commuting Flows for Minority Ethnic Groups in England and Wales, Journal of Ethnic and Migration Studies, Vol.26, No 4, pp.581-608.

46. Parr J.B., (1987): Interaction in an urban system: aspects of trade and commuting, Economic Geogruphy, Vol. 63, No 3., 223-240. 
47. Pissarides C., P. Garibaldi, C. Olivetti, B. Petrongolo E. Wasmer (2000): Women in the Labour Force: How Well is Europe Doing?, OECD.

48. Pisarski A., (2002): Commuting in America II Chapter 4, Eno Transportation Foundation.

49. Pollard K., (2002): Going to Work: Americans' Commuting Patterns in 2000, AmeriStat.

50. Pooley C., J. Turnbull, M. Adams, (2005): Changes in Everyday Mobility in England Since the 1940s: A case study, Human Mobility in a Globalizing World, Belgeo, 1-2, pp.69-83.

51. Population Reports, (2002): Meeting the Urban Challenge, Series M, Number 16.

52. The Rac Foundation, (2003).

53. Reitsma R, F. Vergossen, (1988): A Causal Tipology of Migration. The Role of Commuting, Regional Studies, Vol. 22, No 4, pp. 331-340.

54. Renkow M., D. Hoower, J. Yoder, (1996): Commuting and Migration in North Carolina: Does Suburbanization Explain the Trends?, Department of Agricultural and resource Economics, North Carolina State University.

55. Renkow M., D. Hoower, (2000): Commuting, Migration, and Rural-Urban Population Dynamics, Journal of Regional Science, Vol. 40, No.2, pp.261-287.

56. Rietveld P., S. van Woudenberg, (2003): The utility of travelling when destinations are heterogenous. How much better is the next destination as one travels further?, Journal of Geographical Systems, 5, pp.207-222.

57. Rogers C., (1997): Job search and Unemployment Duration: Implication for the Spatial Mismatch Hypotesis, Journal of Urban Economics, Vol. 42, pp. 109-132.

58. Romani J., Surin J.,Artis M., (2003): Are Commuting and Residential Mobility Decisions Simultaneous?: The Case of Catalonia, Spain, Regional Stydies, Vol. 37, No 8., pp.813-826.

59. Roseman C., (1971): Migration as a Spatial and Temporal process, Annals of the Association of American Geographers Vol. 61, No 3,pp. 589-598.

60. Rouwendal J., P Nijkamp, (2004): Living in Two Worlds: A Review of Home - to Work Decisions, Growth and Change, Vol.35, No 3, pp. 287-303.

61. Rouwendal J., (2004): Search Theory and Commuting Behavior, Growth and Change, Vol. 35 No 3, pp.391-418.

62. Runge J., (1991): Dojazdy do pracy w przestrzennej strukturze powiazan miast wojewodztwa katowickiego, Uniwersytet Slaski, Katowice.

63. Schaller Consulting, (2002): Commuting, Non-Work Travel and the Changing City, An Analysis of Census 2000 Commuting Results for New York City.

64. Schnore L., (1960): Three Sources of Data on Commuting: Problems and Possibilities, Journal of the American Statistical Association, Vol.55, No.289, pp. 8-22.

65. Schwanen T., F.M Dieleman, M. Dijst, (2004): The Impact of Metropolitan Structure on Commute Behavior in the Netherlands: A Multilevel Approach, Growth and Change, Vol.35, No 3, pp. 304-333.

66. Sermons M. W., and F. S. Koppelman, (2001): Representing the differences between female and male commute behavior in residential location choice models, Journal of Transport Geography, Vol.9, Issue 2, pp. 101-110.

67. Shen Q., (2000): Spatial and Social Dimensions of Commuting, Journal of the American Planning Asociation, Vol. 66, No. 1., pp. 66-82.

68. Simpson W., (1987): Workplace location, residential location, and urban commuting, Urban Studies, Vol. 24, No 2., pp.119-128.

69. Skeldon R., (1977): The Evolution of Migration Patterns During Urbanization in Peru, Geographical Review, Vol.67, No.4, pp. 394-411. 
70. Skeldon R., (2006): Interlinkages between Internal and International Migration and Development in the Asian Region, Population, Space and Place,Vol 12, Issue 1, pp. $15-30$.

71. Small K. A., S. Song (1992): "Wasteful" Commuting: A Resolution, The Journal of Political Economy, Vol. 100, No. 4., pp. 888-898.

72. Stark O., Taylor E., (1991): Migration Incentives, Migration Types: The Role of Relative Deprivation, The Economic Journal, Vol.101, No 408, pp.1163-1178.

73. Stock M., P.Duhamel, (2005): A practice-based approach to the conceptualisation of geographical mobility, Human Mobility in a Globalizing World, Belgeo 1-2, pp.59-67.

74. Stone L., (1971): On the Correlation Between Metropolitan Area in- and OutMigration by Occupation, Journal of the American Statistical Association, Vol., 66, No.336, pp. 693-701.

75. Sun S., (1980): The Possibility and Impossibility of Intercity Commuting, Journal of Urban Economics, 23, pp. 86-100.

76. Swindell K., R. Ford, (1975): Places, Migrants and Organization: Some Observations on Population Mobility, Geografiska Annaler, Series B, Human Geography, Vol.57, No.1 pp. 68-76.

77. Taaffe E., H. Gauthier, T. Maraffa, (1980): Extended Commuting and the Intermetropolitan Periphery, Annals of the Association of American Geographers, Vol.70, No.3 pp. 313-329.

78. Thomas D., (1990): The Edge of the City, Transactions of the Institute of British Geographers, New Series, Vol. 15, No. 2., pp. 131-138.

79. Thompson J. H., (1956): Commuting Patterns of Manufacturing Employees, Industrial and Labor Relations Review, Vol. 10, No. 1., pp. 70-80.

80. Turner T., Niemeier D., (1997):Travel to work and household responsibility: new evidence, Transportation, 24, pp.397-419.

81. US Department of Transportation, Commuting to urban areas, Research and Innovative Technology Administration, Washington.

82. Vandersmissen M. H., P. Villeneuve, M. Thériault, (2003): Analyzing Changes in Urban Form and Commuting Time, The Professional Geographer, Vol. 55, Issue 4, pp.446-463.

83. Van der Laan L., (1998): Changing urban systems: An empirical analysis at two spatial levels, Regional Studies, Vol. .32, Issue 3, pp.235-248.

84. Van Ommeren J., Rietveld P., Nijkamp P. (1999): Job Moving, Residential Moving, and Commuting: A Search Perspective, Journal of Urban Economics, 46. pp. 230-253.

85. Zax J, (1991): The Substitution between Moves and Quits, The Economic Journal, Vol. 101, No. 409. pp. 1510-1521.

86. Zax J., (1994), When is a move migration? Regional Science and Urban Economics, Vol. 24 Issue 3, pp.341-360.

87. Zelinski W., (1971): The hypothesis of the mobility transition, Geographical Review, 61, pp. 219-249.

88. Zenou Y., (2002): How do firms redline workers?, CEPR discussion papers 3209.

89. Warnes A., (1975): Commuting towards City Centres: A Study of Population and Employment Density Gradients in Liverpool and Manchester, Transactions of the Institute of British Geographers, No. 64. pp. 77-96.

90. Weber J., M. P. Kvan, (2003): Evaluating the Effects of Geographic Contexts on Individual Accesibilitty: A Multilevel Approach, Urban Geography, 24, 8, pp. $647-$ 671.

91. Wheller J., (1967): Occupational Status and Work Trips: A Minimum Distance Approach, Social Forces, Vol.45, No.4, pp. 508-515. 
92. Wheller J., (1971): Commuting and the Rural Nonfarm Population, The Professional Geographer, Vol. 23, pp.118-122.

93. White M., (1988): Urban Commuting Journeys are not "Wasteful", The Journal of Political Economy, Vol.96, No.5, pp. 1097-1110.

94. White M., (1986): Sex Differences in Urban Commuting Patterns, The American Economic Review, Vol. 76, No 2, pp. 368-372.

95. Wilbur Smith Associates, (1996), San Diego I/15 Congestion Pricing Project.

96. Wood C., (1982): Equilibrium and Historical -Structural Perspectives on Migration, International Migration Review, Vol.16, No2, pp. 298-319.

97. Yu E.Y., (1972): Correlates of Commutation between Central Cities and Rings of SMSA, Social Forces, Vol. 51, No. 1. pp. 74-86.

98. www.eurescom

99. www.bestplaces.net

100. www.bbc.co.uk

101. www.talentscotland.com

102. www.japan-guide.com 


\section{ПРИЛОЗИ:}

Табела 1. Конвергентни дневни мигранти отштине Панчево према насељу становања 2002. године

\begin{tabular}{|c|c|c|c|}
\hline Опитина & Hacerse & $\begin{array}{l}\text { Број дневних } \\
\text { миграната }\end{array}$ & $\begin{array}{l}\text { Удео } \\
(\%)\end{array}$ \\
\hline Панчево & Старчево & 2.016 & 13,8 \\
\hline Панчево & Јабука & 1.637 & 11,2 \\
\hline Панчево & Омољица & 1.474 & 10,1 \\
\hline Панчево & Качарево & 1.356 & 9,3 \\
\hline Панчево & Допово & 1.128 & 7,7 \\
\hline Панчево & 5. Hoвo Ceno & 939 & 6,4 \\
\hline Панчево & Б. Брестовац & 660 & 4,5 \\
\hline Ковин & Баваниште & 575 & 3,9 \\
\hline Панчево & Гnorots & 563 & 3,8 \\
\hline Ковачица & Upenaja & 329 & 2,2 \\
\hline Ковин & Мраморак & 262 & 1,8 \\
\hline Палилула & Београд-део & 259 & 1,8 \\
\hline Нови Београд & Београд-део & 250 & 1,7 \\
\hline Ковин & Ковин & 233 & 1,6 \\
\hline Панчево & Иваново & 218 & 1,5 \\
\hline Панчево & Панчево & 218 & 1,5 \\
\hline Звездара & Београд-део & 186 & 1,3 \\
\hline Алибунар & Владимировац & 166 & 1,1 \\
\hline Вождовац & Београд-део & 145 & 1,0 \\
\hline Ковачица & Ковачица & 142 & 1,0 \\
\hline Земун & Београд-део & 133 & 0,9 \\
\hline Алибунар & Б. Карловац & 132 & 0,9 \\
\hline Onoвo & Сефкерин & 130 & 0,9 \\
\hline Ковачица & Падина & 125 & 0,9 \\
\hline Чукарича & Београд-део & 116 & 0,8 \\
\hline Ковачица & Дебелача & 107 & 0,7 \\
\hline Раковица & Београд-део & 91 & 0,6 \\
\hline Onoso & Onoso & 88 & 0,6 \\
\hline Стари Град & Београд-део & 85 & 0,6 \\
\hline Ковин & Скореновац & 69 & 0,5 \\
\hline Алибунар & Алибунар & 69 & 0,5 \\
\hline Врачар & Београд-део & 65 & 0,4 \\
\hline
\end{tabular}

Извор података: Р3С,2007 Посебна обрада података. 
Табела 2. Дивергентни дневни мигранти општине Панчево према насељу рала 2002.године

\begin{tabular}{|l|l|c|c|}
\hline \multicolumn{1}{|c|}{ Општина } & \multicolumn{1}{|c|}{ Насеље } & Број дневних миграната & $\begin{array}{c}\text { Удео } \\
(\%)\end{array}$ \\
\hline $\begin{array}{l}\text { Непозната } \\
\text { београдска општина }\end{array}$ & $\begin{array}{l}\text { Непознато } \\
\text { 6еоградско насеље }\end{array}$ & 5.520 & 65,1 \\
\hline Палилула & Београд-део & 400 & 4,7 \\
\hline Стари Град & Београд-део & 376 & 4,4 \\
\hline Савски Венац & Београд-део & 334 & 3,9 \\
\hline Земун & Београд-део & 320 & 3,8 \\
\hline Звездара & Београд-део & 210 & 2,5 \\
\hline Нови Београд & Београд-део & 177 & 2,1 \\
\hline Врачар & Београд-део & 155 & 1,8 \\
\hline Вождовац & Београд-део & 141 & 1,7 \\
\hline Алибунар & Алибунар & 80 & 0,9 \\
\hline Ковачица & Ковачица & 80 & 0,9 \\
\hline Чукарица & Београд-део & 66 & 0,8 \\
\hline Ковин & Ковин & 59 & 0,7 \\
\hline Палилула & Падинска Скела & 57 & 0,7 \\
\hline Вршац & Вршац & 48 & 0,6 \\
\hline Нови Сад- Град & Нови Сад & 29 & 0,3 \\
\hline Алибунар & Владимировац & 25 & 0,3 \\
\hline Зрењанин & Зренанин & 23 & 0,3 \\
\hline Ковачица & Црепаја & 22 & 0,3 \\
\hline Опово & Опово & 19 & 0,2 \\
\hline
\end{tabular}

Извор података: Р3С,2007 Посебна обрада података. 
Табела 3. Старосно-полна структура

конвергентних активних дневних миграната општине Панчево 2002. године

\begin{tabular}{|c|c|c|c|c|c|c|c|c|c|c|c|c|}
\hline \multirow{3}{*}{$\begin{array}{c}\text { Место } \\
\text { становања/non }\end{array}$} & \multirow{3}{*}{$\begin{array}{c}\text { Укупно } \\
\text { РДМ }\end{array}$} & & \multicolumn{10}{|c|}{ Старосна група } \\
\hline & & & \multicolumn{2}{|c|}{$15-19$} & \multicolumn{2}{|c|}{$20-39$} & \multicolumn{2}{|c|}{$40-59$} & \multicolumn{2}{|c|}{$60+$} & \multicolumn{2}{|c|}{ непознато } \\
\hline & & $\%$ & $6 \mathrm{poj}$ & $\%$ & $6 p o j$ & $\%$ & $6 p 01$ & $\%$ & $6 p 01$ & $\%$ & $6 \mathrm{poj}$ & $\%$ \\
\hline Б. Брестовац & 38 & 100,0 & & & 17 & 44,7 & 20 & 52,6 & & & 1 & 2,6 \\
\hline мушкарци & 16 & 42,1 & & & 5 & 31,2 & 11 & 62,5 & & & & \\
\hline жене & 22 & 57,9 & & & 12 & 54,5 & 9 & 40,9 & & & 1 & 4,5 \\
\hline 5. Ново Село & 43 & 100,0 & 1 & 2,3 & 22 & 51,2 & 20 & 46,5 & & & & \\
\hline мушкарци & 19 & 44,2 & 1 & 5,3 & 10 & 52,6 & 8 & 42,1 & & & & \\
\hline жене & 24 & 55,8 & & & 12 & 50,0 & 12 & 50,0 & & & & \\
\hline Долово & 39 & 100,0 & & & 17 & 43,6 & 21 & 53,8 & 1 & 2,6 & & \\
\hline мушкарци & 19 & 48,7 & & & 8 & 42,1 & 10 & 52,6 & 1 & 5,3 & & \\
\hline жене & 20 & 51,3 & & & 9 & 45,0 & 11 & 55,0 & & & & \\
\hline Гnorolt & 28 & 100,0 & & & 14 & 50,0 & 14 & 50,0 & & & & \\
\hline мушкарци & 14 & 50,0 & & & 7 & 50,0 & 7 & 50,0 & & & & \\
\hline жене & 14 & 50,0 & & & 7 & 50,0 & 7 & 50,0 & & & & \\
\hline Иваново & 18 & 100,0 & & & 8 & 44,4 & 10 & 55,6 & & & & \\
\hline мушкарци & 11 & 61,1 & & & 4 & & 7 & & & & & \\
\hline жене & 7 & 38,9 & & & 4 & & 3 & & & & & \\
\hline Јабука & 82 & 100,0 & & & 35 & 42,7 & 46 & 56,1 & 1 & 1,2 & & \\
\hline мушкарци & 43 & 52,4 & & & 16 & 36,4 & 27 & 62,8 & & & & \\
\hline жене & 39 & 47,6 & & & 19 & 48,7 & 19 & 48,7 & 1 & 2,6 & & \\
\hline Качарево & 52 & 100,0 & 1 & 1,9 & 23 & 44,2 & 28 & 53,8 & & & & \\
\hline мушкарци & 32 & 61,5 & 1 & 3,1 & 18 & 56,2 & 13 & 40,6 & & & & \\
\hline жене & 20 & 38,5 & & & 5 & 25,0 & 15 & 75,0 & & & & \\
\hline Омољица & 58 & 100,0 & & & 35 & 60,3 & 22 & 37,9 & & & 1 & 1,7 \\
\hline мушкарци & 29 & 50,0 & & & 19 & 65,5 & 19 & 65,5 & & & 1 & 3,4 \\
\hline жене & 29 & 50,0 & & & 16 & 55,2 & 13 & 44,8 & & & & \\
\hline Панчево & 11.570 & 100,0 & 63 & 0,5 & 4.735 & 40,9 & 6.654 & 57,5 & 74 & 0,6 & 44 & 0,4 \\
\hline мушкарци & 7.881 & 68,1 & 35 & 0,4 & 3.213 & 40,8 & 4.543 & 57,6 & 65 & 0,8 & 25 & 0,3 \\
\hline жere & 3.689 & 31,9 & 28 & 0,7 & 1.522 & 41,2 & 2.111 & 57,2 & 9 & 0,2 & 19 & 0,5 \\
\hline Cтарчево & 86 & 100,0 & 2 & 2,3 & 43 & 50,0 & 39 & 45,3 & 1 & 1,2 & 1 & 1,2 \\
\hline мушкарци & 38 & 44,2 & & & 18 & 47,4 & 19 & 50,0 & 1 & 2,6 & & \\
\hline жене & 48 & 55,8 & 2 & 4,2 & 25 & 52,1 & 20 & 41,7 & & & 1 & 2,1 \\
\hline Општина & 12.014 & 100,0 & 67 & 0,6 & 4.949 & 41,2 & 6.874 & 57,2 & 77 & 0,6 & 47 & 0,4 \\
\hline мушкарци & 8.102 & 67,4 & 37 & 0,4 & 3.318 & 40,9 & 4.654 & 57,4 & 67 & 0,8 & 26 & 0,3 \\
\hline жене & 3.912 & 32,6 & 30 & 0,8 & 1.631 & 41,7 & 2.220 & 56,7 & 10 & 0,2 & 21 & 0,5 \\
\hline
\end{tabular}

Изнор података: Р3С,2007 Посебна обрада података. 
Табела 4. Старосно-полна структура

дивергентних активних дневних миграната општине Панчево 2002. године

\begin{tabular}{|c|c|c|c|c|c|c|c|c|c|c|c|c|}
\hline \multirow{3}{*}{ Место рада } & \multirow{3}{*}{$\begin{array}{c}\text { Укугтно } \\
\text { РДМ }\end{array}$} & & \multicolumn{10}{|c|}{ Старосна група } \\
\hline & & & \multicolumn{2}{|c|}{$15-19$} & \multicolumn{2}{|c|}{ 20-39 } & \multicolumn{2}{|c|}{$40-59$} & \multicolumn{2}{|c|}{$60+$} & \multicolumn{2}{|c|}{ непознато } \\
\hline & & $\%$ & $6 \mathrm{poj}$ & $\%$ & $6 p o j$ & $\%$ & 6 poj & $\%$ & $6 \mathrm{poj}$ & $\%$ & $6 \mathrm{poj}$ & $\%$ \\
\hline Б. Брестовац & 59 & 100,0 & & & 32 & 54,2 & 26 & 44,1 & 1 & 1,7 & & \\
\hline мушкарци & 42 & 71,2 & & & 22 & 52,4 & 19 & 45,2 & 1 & 2,4 & & \\
\hline жене & 17 & 28,8 & & & 10 & 58,9 & 7 & 41,2 & & & & \\
\hline 5. Hoвo Ceno & 189 & 100,0 & 2 & 1,1 & 87 & 46,0 & 97 & 51,3 & 3 & 1,6 & & \\
\hline мушкарци & 144 & 76,2 & 2 & 1,4 & 59 & 40,9 & 80 & 55,5 & 3 & 2,1 & & \\
\hline жене & 45 & 23,8 & & & 28 & 62,2 & 17 & 37,8 & & & & \\
\hline Долово & 132 & 100,0 & 1 & 0,8 & 69 & 52,3 & 59 & 44,7 & 2 & 1,5 & 1 & 0,8 \\
\hline мушкарци & 100 & 75,8 & 1 & 1,0 & 46 & 46,0 & 51 & 51,0 & 1 & 1,0 & 1 & 1,0 \\
\hline жене & 32 & 24,2 & & & 23 & 71,9 & 8 & 25,0 & 1 & 3,1 & & \\
\hline Tnorots & 183 & 100,0 & 2 & 1,1 & 80 & 43,7 & 96 & 52,5 & 5 & 2,7 & & \\
\hline мушкарци & 147 & 80,3 & 1 & 0,7 & 64 & 43,5 & 77 & 52,4 & 5 & 3,4 & & \\
\hline жене & 36 & 19,7 & 1 & 2,8 & 16 & 44,4 & 19 & 52,8 & & & & \\
\hline Иваново & 7 & 100,0 & & & 2 & 28,6 & 5 & 71,4 & & & & \\
\hline мушкарци & 5 & 71,4 & & & 1 & 20,0 & 4 & 80,0 & & & & \\
\hline жене & 2 & 28,6 & & & 1 & 50,0 & 1 & 50,0 & & & & \\
\hline Јабука & 139 & 100,0 & & & 76 & 54,7 & 62 & 44,6 & 1 & 0,7 & & \\
\hline мушкарци & 104 & 74,8 & & & 55 & 52,9 & 48 & 46,1 & 1 & 1,0 & & \\
\hline жене & 35 & 25,2 & & & 21 & 60,0 & 14 & 40,0 & & & & \\
\hline Качарево & 494 & 100,0 & 3 & 0,6 & 234 & 47,4 & 255 & 51,6 & 2 & 0,4 & & \\
\hline мушкарци & 336 & 68,0 & 2 & 0,6 & 136 & 40,5 & 196 & 58,3 & 2 & 0,6 & & \\
\hline жене & 158 & 32,0 & 1 & 0,6 & 98 & 62,0 & 59 & 37,3 & & & & \\
\hline Омольица & 95 & 100,0 & 1 & 1,1 & 44 & 46,3 & 47 & 49,5 & 1 & 1,1 & 2 & 2,1 \\
\hline мушкарци & 62 & 65,3 & 1 & 1,6 & 27 & 43,5 & 33 & 0,5 & & & 1 & 1,6 \\
\hline жене & 33 & 34,7 & & & 17 & 51,5 & 14 & 42,4 & 1 & 3,0 & 1 & 3,0 \\
\hline Панчево & 2.853 & 100,0 & 23 & 0,8 & 1.347 & 47,2 & 1.447 & 50,7 & 26 & 0,9 & 10 & 0,3 \\
\hline мушкарци & 1679 & 58,9 & 8 & 0,5 & 774 & 46,1 & 870 & 51,8 & 26 & 1,5 & 1 & 0,1 \\
\hline жене & 1174 & 41,1 & 15 & 1,3 & 573 & 48,8 & 577 & 49,1 & & & 9 & 0,8 \\
\hline Crapчeвo & 190 & 100,0 & 4 & 2,1 & 101 & 53,2 & 82 & 43,2 & 1 & 0,5 & 2 & 1,0 \\
\hline мушкарци & 123 & 64,7 & 3 & 2,4 & 65 & 52,8 & 52 & 42,3 & 1 & 0,8 & 2 & 1,6 \\
\hline жене & 67 & 35,3 & 1 & 1,5 & 36 & 53,7 & 30 & 44,8 & & & & \\
\hline Onuтина & 4.341 & 100,0 & 36 & 0,8 & 2.072 & 47,7 & 2.176 & 50,1 & 42 & 1,0 & 15 & 0,3 \\
\hline мушкарци & 2.742 & 63,2 & 18 & 0,6 & 1.249 & 45,5 & 1430 & 52,1 & 40 & 1,4 & 5 & 0,2 \\
\hline жене & 1.599 & 36,8 & 18 & 1,1 & 823 & 51,5 & 746 & 46,6 & 2 & 0,1 & 10 & 0,6 \\
\hline
\end{tabular}

Извор података: Р3С,2007 Посебна обрала података. 
Табела 5. Структура породица

конвергентних активних дневних миграната општине Панчево 2002. године (\%)

\begin{tabular}{|c|c|c|c|c|c|c|c|c|}
\hline \multirow[t]{2}{*}{ Територија } & & \multirow[t]{2}{*}{ Укупно } & \multicolumn{2}{|c|}{$\begin{array}{c}\text { Да ли је супружник } \\
\text { запоспен }\end{array}$} & \multicolumn{2}{|c|}{$\begin{array}{c}\text { Да ли имају децу млађу } \\
\text { од } 7 \text { година }\end{array}$} & \multicolumn{2}{|c|}{$\begin{array}{c}\text { Да ли у домаһинству } \\
\text { живи још неко ко није } \\
\text { члан породице }\end{array}$} \\
\hline & & & не & да & не & да & He & да \\
\hline \multirow[t]{4}{*}{ Општина } & Путује једно & 69.4 & 75.9 & 24.1 & 70.2 & 29.8 & 83.3 & 16.7 \\
\hline & Путује муж & 80.5 & 81.3 & 18.7 & 68.3 & 31.7 & 83.0 & 17.0 \\
\hline & Путује жена & 19.5 & 53.8 & 46.2 & 78.1 & 21.9 & 84.8 & 15.2 \\
\hline & Путуру обоје & 30.6 & 1.4 & 98.6 & 78.3 & 21.7 & 85.3 & 14.7 \\
\hline \multirow[t]{4}{*}{ Б. Брестовац } & Путује једно & 65.6 & 42.9 & 57.1 & 76.2 & 23.8 & 90.5 & 9.5 \\
\hline & Путује муж & 57.1 & 58.3 & 41.7 & 83.3 & 16.7 & 91.7 & 8.3 \\
\hline & Путује жена & 42.9 & 22.2 & 77.8 & 66.7 & 33.3 & 88.9 & 11.1 \\
\hline & Путуту o6oje & 34.4 & 0.0 & 100.0 & 72.7 & 27.3 & 72.7 & 27.3 \\
\hline \multirow[t]{4}{*}{ Б. Ново Село } & Путује једно & 71.9 & 47.8 & 52.2 & 82.6 & 17.4 & 91.3 & 8.7 \\
\hline & Путује муж & 47.8 & 72.7 & 27.3 & 72.7 & 27.3 & 81.8 & 18.2 \\
\hline & Путује жена & 52.2 & 25.0 & 75.0 & 91.7 & 8.3 & 100.0 & 0.0 \\
\hline & Пyтyly o6oje & 18.8 & 0.0 & 100.0 & 50.0 & 50.0 & 83.3 & 16.7 \\
\hline \multirow[t]{4}{*}{ Tnorots } & Путује једно & 75.0 & 53.3 & 46.7 & 80.0 & 20.0 & 93.3 & 6.7 \\
\hline & Путује муж & 46.7 & 85.7 & 14.3 & 85.7 & 14.3 & 85.7 & 14.3 \\
\hline & Путује жена & 53.3 & 25.0 & 75.0 & 75.0 & 25.0 & 100.0 & 0.0 \\
\hline & Путују o6oje & 20.0 & 0.0 & 100.0 & 50.0 & 50.0 & 75.0 & 25.0 \\
\hline \multirow[t]{4}{*}{ Долово } & Путује једно & 71.4 & 66.7 & 33.3 & 93.3 & 6.7 & 86.7 & 13.3 \\
\hline & Путује муж & 66.7 & 90.0 & 10.0 & 90.0 & 10.0 & 90.0 & 10.0 \\
\hline & Путује жена & 33.3 & 20.0 & 80.0 & 100.0 & 0.0 & 80.0 & 20.0 \\
\hline & Путују o6 оје & 28.6 & 0.0 & 100.0 & 83.3 & 16.7 & 100.0 & 0.0 \\
\hline \multirow[t]{4}{*}{ Иваново } & Путује једно & 75.0 & 44.4 & 55.6 & 88.9 & 11.1 & 77.8 & 22.2 \\
\hline & Путује муж & 66.7 & 50.0 & 50.0 & 83.3 & 16.7 & 66.7 & 33.3 \\
\hline & Путује жена & 33.3 & 33.3 & 66.7 & 100.0 & 0.0 & 100.0 & 0.0 \\
\hline & Путују o6oje & 25.0 & 33.3 & 66.7 & 66.7 & 33.3 & 100.0 & 0.0 \\
\hline \multirow[t]{4}{*}{ Јабука } & Путује једно & 73.7 & 47.6 & 52.4 & 78.6 & 21.4 & 88.1 & 11.9 \\
\hline & Путује муж & 57.1 & 70.8 & 29.2 & 83.3 & 16.7 & 83.3 & 16.7 \\
\hline & Путује жена & 42.9 & 16.7 & 83.3 & 72.2 & 27.8 & 94.4 & 5.6 \\
\hline & Путују oбоје & 24.6 & 0.0 & 100.0 & 78.6 & 21.4 & 85.7 & 14.3 \\
\hline \multirow[t]{4}{*}{ Качарево } & Путује једно & 84.8 & 50.0 & 50.0 & 75.0 & 25.0 & 85.7 & 14.3 \\
\hline & Путује муж & 60.7 & 58.8 & 41.2 & 64.7 & 35.3 & 82.4 & 17.6 \\
\hline & Путује жена & 39.3 & 36.4 & 63.6 & 90.9 & 9.1 & 90.9 & 9.1 \\
\hline & Путуту o6oje & 15.2 & 0.0 & 100.0 & 100.0 & 0.0 & 80.0 & 20.0 \\
\hline \multirow[t]{4}{*}{ Омалица } & Путује једно & 63.9 & 52.2 & 47.8 & 60.9 & 39.1 & 87.0 & 13.0 \\
\hline & Путује муж & 60.9 & 78.6 & 21.4 & 42.9 & 57.1 & 92.9 & 7.1 \\
\hline & Путује жена & 39.1 & 11.1 & 88.9 & 88.9 & 11.1 & 77.8 & 22.2 \\
\hline & Путују o6оје & 36.1 & 0.0 & 100.0 & 69.2 & 30.8 & 84.6 & 15.4 \\
\hline \multirow[t]{4}{*}{ Панчево } & Путује једно & 69.3 & 77.0 & 23.0 & 69.9 & 30.1 & 83.1 & 16.9 \\
\hline & Путује муж & 81.5 & 81.6 & 18.4 & 68.1 & 31.9 & 82.8 & 17.2 \\
\hline & Путује жена & 18.5 & 57.1 & 42.9 & 77.8 & 22.2 & 84.1 & 15.9 \\
\hline & Путују o6oje & 30.7 & 1.4 & 98.6 & 78.5 & 21.5 & 85.3 & 14.7 \\
\hline \multirow[t]{4}{*}{ Старчево } & Путује једно & 67.2 & 48.8 & 51.2 & 68.3 & 31.7 & 92.7 & 7.3 \\
\hline & Путује муж & 53.7 & 81.8 & 18.2 & 63.6 & 36.4 & 95.5 & 4.5 \\
\hline & Путује жена & 46.3 & 10.5 & 89.5 & 73.7 & 26.3 & 89.5 & 10.5 \\
\hline & Путују обоје & 32.8 & 0.0 & 100.0 & 70.0 & 30.0 & 85.0 & 15.0 \\
\hline
\end{tabular}

Извор података: Р3С,2007 Посебин обрада података. 
Табела 6. Структура породища

дивергентних активних дневних миграната општине Панчево 2002. године (\%)

\begin{tabular}{|c|c|c|c|c|c|c|c|c|}
\hline \multirow[t]{2}{*}{ Територија } & & \multirow[t]{2}{*}{ Укупно } & \multicolumn{2}{|c|}{$\begin{array}{c}\text { Да ли је супружник } \\
\text { запослен }\end{array}$} & \multicolumn{2}{|c|}{$\begin{array}{c}\text { Да ли имају децу млађу } \\
\text { од } 7 \text { година }\end{array}$} & \multicolumn{2}{|c|}{$\begin{array}{c}\text { Да ли у домаһинству } \\
\text { живи још неко ко није } \\
\text { члан породиче }\end{array}$} \\
\hline & & & He & да & He & да & He & да \\
\hline \multirow[t]{4}{*}{ Onuтина } & Путује једно & 90.5 & 47.8 & 52.2 & 72.1 & 27.9 & 88.4 & 11.6 \\
\hline & Путује муж & 70.8 & 57.3 & 42.7 & 69.6 & 30.4 & 87.9 & 12.1 \\
\hline & Путује жена & 29.2 & 24.9 & 75.1 & 78.2 & 21.8 & 89.6 & 10.4 \\
\hline & Путуjy o6oje & 9.5 & 0.0 & 100.0 & 71.4 & 28.6 & 89.2 & 10.8 \\
\hline \multirow[t]{4}{*}{ Б. Брестовац } & Путује једно & 97.6 & 72.5 & 27.5 & 67.5 & 32.5 & 85.0 & 15.0 \\
\hline & Путује муж & 75.0 & 83.3 & 16.7 & 70.0 & 30.0 & 86.7 & 13.3 \\
\hline & Путује жена & 25.0 & 40.0 & 60.0 & 60.0 & 40.0 & 80.0 & 20.0 \\
\hline & Путују обоје & 2.4 & 0.0 & 100.0 & 0.0 & 100.0 & 0.0 & 100.0 \\
\hline \multirow[t]{4}{*}{ Б. Hoso Ceno } & Путује једно & 92.2 & 58.0 & 42.0 & 74.8 & 25.2 & 84.9 & 15.1 \\
\hline & Путује муж & 78.2 & 64.5 & 35.5 & 74.2 & 25.8 & 86.0 & 14.0 \\
\hline & Путује жена & 21.8 & 34.6 & 65.4 & 76.9 & 23.1 & 80.8 & 19.2 \\
\hline & Путују обоје & 7.8 & 0.0 & 100.0 & 70.0 & 30.0 & 80.0 & 20.0 \\
\hline \multirow[t]{4}{*}{ Fnorots } & Путује једно & 95.5 & 78.6 & 21.4 & 73.0 & 27.0 & 87.3 & 12.7 \\
\hline & Путује муж & 85.7 & 83.3 & 16.7 & 69.4 & 30.6 & 85.2 & 14.8 \\
\hline & Путује жена & 14.3 & 50.0 & 50.0 & 94.4 & 5.6 & 100.0 & 0.0 \\
\hline & Путују обоје & 4.5 & 0.0 & 100.0 & 100.0 & 0.0 & 116.7 & 0.0 \\
\hline \multirow[t]{4}{*}{ Aопово } & Путује једно & 95.4 & 72.3 & 27.7 & 60.2 & 39.8 & 86.7 & 13.3 \\
\hline & Путује муж & 85.5 & 78.9 & 21.1 & 60.6 & 39.4 & 87.3 & 12.7 \\
\hline & Путује жена & 14.5 & 33.3 & 66.7 & 58.3 & 41.7 & 83.3 & 16.7 \\
\hline & Путују о6оje & 4.6 & 0.0 & 100.0 & 75.0 & 25.0 & 100.0 & 0.0 \\
\hline \multirow[t]{3}{*}{ Иваново } & Путује једно & 100.0 & 75.0 & 25.0 & 100.0 & 0.0 & 50.0 & 50.0 \\
\hline & Путује муж & 50.0 & 100.0 & 0.0 & 100.0 & 0.0 & 50.0 & 50.0 \\
\hline & Путује жена & 50.0 & 50.0 & 50.0 & 100.0 & 0.0 & 50.0 & 50.0 \\
\hline \multirow[t]{4}{*}{ Јабука } & Путује једно & 97.0 & 56.3 & 43.8 & 66.7 & 33.3 & 88.5 & 10.4 \\
\hline & Путује муж & 83.3 & 63.8 & 36.3 & 66.3 & 33.8 & 90.0 & 10.0 \\
\hline & Путује жена & 16.7 & 18.8 & 81.3 & 68.8 & 31.3 & 81.3 & 12.5 \\
\hline & Путуjу o6oje & 3.0 & 0.0 & 100.0 & 66.7 & 33.3 & 0.0 & 100.0 \\
\hline \multirow[t]{4}{*}{ Качарево } & Путује једно & 86.7 & 59.3 & 40.7 & 71.6 & 28.4 & 88.8 & 11.2 \\
\hline & Путује муж & 80.6 & 66.2 & 33.8 & 71.3 & 28.7 & 87.5 & 12.5 \\
\hline & Путује жена & 19.4 & 30.8 & 69.2 & 73.1 & 26.9 & 94.2 & 5.8 \\
\hline & Путуjу o6oje & 13.3 & 0.0 & 100.0 & 63.4 & 36.6 & 90.2 & 9.8 \\
\hline \multirow[t]{4}{*}{ Омољица } & Путује једно & 97.1 & 59.7 & 40.3 & 73.1 & 26.9 & 80.6 & 19.4 \\
\hline & Путује мумк & 67.2 & 73.3 & 26.7 & 66.7 & 33.3 & 77.8 & 22.2 \\
\hline & Путује жена & 32.8 & 31.8 & 68.2 & 86.4 & 13.6 & 86.4 & 13.6 \\
\hline & Путуіу обоje & 2.9 & 0.0 & 100.0 & 100.0 & 0.0 & 100.0 & 0.0 \\
\hline \multirow[t]{4}{*}{ Панчево } & Путује једно & 89.5 & 39.3 & 60.7 & 73.6 & 26.4 & 89.6 & 10.5 \\
\hline & Путује мужк & 66.1 & 47.9 & 52.1 & 70.4 & 29.6 & 89.7 & 10.3 \\
\hline & Пугује жена & 33.9 & 22.6 & 77.4 & 79.9 & 20.1 & 89.3 & 10.9 \\
\hline & Путуjy o6oje & 10.5 & 0.0 & 100.0 & 72.0 & 28.0 & 90.1 & 9.3 \\
\hline \multirow[t]{4}{*}{ Cтарчево } & Путује једно & 92.2 & 50.0 & 50.0 & 61.9 & 38.1 & 84.7 & 15.3 \\
\hline & Путује муж & 67.8 & 63.8 & 36.3 & 61.3 & 38.8 & 77.5 & 22.5 \\
\hline & Путује жена & 32.2 & 21.1 & 78.9 & 63.2 & 36.8 & 100.0 & 0.0 \\
\hline & Путуjy o6oje & 7.8 & 0.0 & 100.0 & 80.0 & 20.0 & 90.0 & 10.0 \\
\hline
\end{tabular}


Прилог 1.

\title{
Изјава о ауторству
}

Потписани-а Лукић, Весна М.

\author{
Изјављујем
}

да је докторска дисертација под насловом

\section{Конвергентне и дивергентне дневне миграције становништва}

\section{Панчева}

- резултат сопственог истраживачког рада,

- да предложена дисертација у целини ни у деловима није била предложена за добијање било које дипломе према студијским програмима других високошколских установа,

- да су резултати коректно наведени и

- да нисам кршио/ла ауторска права и користио интелектуалну својину других лица.

Потпис

У Београду, 16.12.2013. године

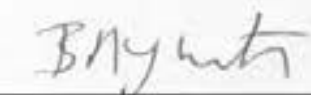


Прилог 2.

\section{Изјава о коришћењу}

Овлашћујем Универзитетску библиотеку „Светозар Марковић“ да у Дигитални репозиторијум Универзитета у Београду унесе моју докторску дисертацију под насловом:

Конвергентне и дивергентне дневне миграције становништва Панчева

која је моје ауторско дело.

Дисертацију са свим прилозима предао/ла сам у електронском формату погодном за трајно архивирање.

Моју докторску дисертацију похрањену у Дигитални репозиторијум Универзитета у Београду могу да користе сви који поштују одредбе садржане у одабраном типу лиценце Креативне заједнице (Creative Commons) за коју сам се одлучио/ла.

1. Ауторство

2. Ауторство - некомерцијално

3. Ауторство - некомерцијално - без прераде

4. Ауторство - некомерцијално - делити под истим условима

5. Ауторство - без прераде

6. Ауторство - делити под истим условима

(Молимо да заокружите само једну од шест понуђених лиценци, кратак опис лиценци дат је на полеђини листа).

\section{Потпис}

У Београду, 16.12.2013.године

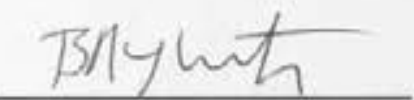

